\title{
MAY 162012
}

Tim Murphy, Chief

Bureau of Federal Facilities

Division of Environmental Protection

2030 East Flamingo Road, Suite 230

Las Vegas, NV 89119-0818

SUBMITTAL OF THE FINAL POST-CLOSURE INSPECTION LETTER REPORT FOR CORRECTIVE ACTION UNITS (CAUs) ON THE NEVADA NATIONAL SECURITY SITE (NNSS), MAY 2012

This letter serves as the post-closure inspection letter report for CAUs on the NNSS for Calendar Year 2011.

\section{INIDUSTRIAL SITES}

The following use restricted sites were closed under the Industrial Sites Activity.

\section{CAU 5, Landfills}

Eight Corrective Action Sites (CASs) in CAU 5 require inspections. CAS 05-15-01, CAS 06-15-02, and CAS 06-15-03 were inspected on November 8, 2011. CAS 05-16-01 and CAS 06-08-01 were inspected on November 14, 2011. CAS 12-15-01 and CAS 20-15-01 were inspected on October 18, 2011. CAS 23-15-03 was inspected on December 12, 2011.

During the previous inspections performed for Calendar Year 2010, T-posts were loose and several signs were down or missing at CAS 05-15-01, CAS 05-16-01, CAS 12-15-01, and CAS 23-15-03. Minor fence repair was required at CAS 12-15-01. Sign and fence maintenance was completed in March and April of 2011. During the 2011 inspections, one T-post was damaged at CAS 23-15-03, and several signs were down at CAS 06-08-01, CAS 06-15-02, CAS 06-15-03, and CAS 23-15-03. Sign and T-post maintenance will be completed in 2012. No other issues were identified.

The CASs in CAU 5 require annual inspections for the first 5 years after closure and once every 5 years thereafter for a total of 30 years. The sites have been inspected annually for the past 5 years and will not be inspected again until 2016.

\section{CAU 113, Area 25 R-MAD Facility}

One CAS in CAU 113 requires inspection. CAS 25-41-01 was inspected on December 19, 2011. No issues were identified, and no maintenance or repairs were required.

\section{CAU 115, Area 25 Test Cell A Facility}

One CAS in CAU 115 requires inspection. CAS 25-41-04 was inspected on December 20, 2011. No issues were identified, and no maintenance or repairs were required. 


\section{CAU 116, Area 25 Test Cell C Facility}

One CAS in CAU 116 requires inspection. CAS 25-41-05 was inspected on December 20, 2011. No issues were identified, and no maintenance or repairs were required.

\section{CAU 118, Area 27 Super Kukla Facility}

One CAS in CAU 118 requires inspection. CAS 27-41-01 was inspected on December 20, 2011. During the previous inspection performed for Calendar Year 2010, minor fence repair was required. Fence maintenance was completed in March 2011. During the 2011 inspection, no issues were identified, and no maintenance or repairs were required.

\section{CAU 127, Areas 25 and 26 Storage Tanks}

Two CASs in CAU 127 require inspections. CAS 25-01-07 and CAS 25-02-02 were inspected on December 19, 2011. One sign was down and one sign was loose at CAS 25-01-07. Sign maintenance will be completed in 2012. No other issues were identified.

\section{CAU 137, Waste Disposal Sites}

Four CASs in CAU 137 require inspections. CAS 01-08-01 and CAS 07-23-02 were inspected on November 8, 2011. CAS 12-08-01 and CAS 12-23-07 were inspected on October 18, 2011. During the previous inspections performed for Calendar Year 2010, several faded signs needed to be replaced at CAS 07-23-02, CAS 12-08-01, and CAS 12-23-07. Sign maintenance was completed in April and May 2011. During the 2011 inspections, three faded signs needed to be replaced and one sign was loose at CAS 01-08-01. Sign maintenance will be completed in 2012. No other issues were identified.

\section{CAU 139, Waste Disposal Sites}

Two CASs in CAU 139 require inspections. CAS 06-19-03 was inspected on November 8, 2011. CAS 09-23-01 was inspected on November 1, 2011. During the previous inspections performed for Calendar Year 2010, minor fence repair was required at CAS 09-23-01. Fence maintenance was completed in March 2011. During the 2011 inspections, minor fence repair was required at CAS 09-23-01. Fence maintenance will be completed in 2012. No other issues were identified.

\section{CAU 140, Waste Dumps, Burn Pits, and Storage Area}

Two CASs in CAU 140 require inspections. CAS 05-23-01 was inspected on November 8, 2011. CAS 23-17-01 was inspected on December 12, 2011. During the previous inspections performed for Calendar Year 2010, one sign was loose at CAS 05-23-01, and one sign was down at CAS 23-17-01. Minor fence repair was required at CAS 05-23-01. Sign and fence maintenance was completed in March 2011. During the 2011 inspections, no issues were identified, and no maintenance or repairs were required.

\section{CAU 143, Area 25 Contaminated Waste Dumps}

Two CASs in CAU 143 require inspections. CAS 25-23-03 and CAS 25-23-09 were inspected on December 19, 2011. During the previous inspections performed for Calendar Year 2010, one sign was down at CAS 25-23-09. Sign maintenance was completed in April 2011. During the 2011 
inspections, four signs were down, one sign was loose, and two missing signs and one damaged sign needed to be replaced at CAS 25-23-09. Sign maintenance will be completed in 2012. No other issues were identified.

\section{CAU 145, Wells and Storage Holes}

One CAS in CAU 145 requires inspection. CAS 03-25-01 was inspected on November 8, 2011. One sign was down. Sign maintenance will be completed in 2012. No other issues were identified.

\section{CAU 151, Septic Systems and Discharge Area}

One CAS in CAU 151 requires inspection. CAS 12-03-01 (Lagoon A) was inspected on October 18, 2011. No issues were identified, and no maintenance or repairs were required.

\section{CAU 165, Area 25 and 26 Dry Well and Washdown Areas}

One CAS in CAU 165 requires inspection. CAS 25-20-01 was inspected on December 19, 2011. One sign was loose. Sign maintenance will be completed in 20.12. No other issues were identified.

\section{CAU 168, Area 25 and 26 Contaminated Materials and Waste Dumps}

Three CASs in CAU 168 require inspections. CAS 25-16-03, CAS 25-23-02, and CAS 25-99-16 were inspected on December 19,2011. One sign was down at CAS 25-23-02. Sign maintenance will be completed in 2012. No other issues were identified.

These three CASs in CAU 168 require annual inspections for the first 5 years after closure and once every 5 years thereafter for a total of 30 years. The sites have been inspected annually for the past 5 years and will not be inspected again until 2016.

\section{CAU 204, Storage Bunkers}

Five CASs in CAU 204 require inspections. CAS 01-34-01, CAS 03-34-01, and CAS 05-33-01 were inspected on November 8, 2011. CAS 02-34-01 was inspected on October 24, 2011. CAS 05-18-02 was inspected on November 14, 2011. No issues were identified, and no maintenance or repairs were required.

\section{CAU 254, Area 25 R-MAD Decontamination Facility}

One CAS in CAU 254 requires inspection. CAS 25-23-06 was inspected on December 19, 2011. No issues were identified, and no maintenance or repairs were required.

\section{CAU 261, Area 25 Test Cell A Leachfield System}

One CAS in CAU 261 requires inspection. CAS 25-05-01 was inspected on December 20, 2011. Two signs were loose. Sign maintenance will be completed in 2012. No other issues were identified.

\section{CAU 262, Area 25 Septic Systems and UDP}

Three CASs in CAU 262 require inspections. CAS 25-02-06 and CAS 25-05-08 were inspected on December 20, 2011. CAS 25-05-03 was inspected on December 19, 2011. During the previous inspections performed for Calendar Year 2010, one faded sign needed to be replaced at 
CAS 25-02-06. Sign maintenance was completed in June 2011. During the 2011 inspections, three signs were down at CAS 25-05-03, and one obsolete sign needed to be replaced at CAS 25-05-08. Sign maintenance will be completed in 2012. No other issues were identified.

\section{CAU 309, Area 12 Muckpiles}

Three CASs in CAU 309 require inspections. CAS 12-06-09, CAS 12-08-02, and CAS 12-28-01 were inspected on October 19, 2011. No issues were identified, and no maintenance or repairs were required.

\section{CAU 322, Areas 1 \& 3 Release Sites and Injection Wells}

One CAS in CAU 322 requires inspection. CAS 03-20-05 was inspected on November 8, 2011. During the previous inspections performed for Calendar Year 2010, two signs were down, and minor fence repair was required. Sign and fence maintenance was completed in March 2011. During the 2011 inspection, no issues were identified, and no maintenance or repairs were required.

CAS 03-20-05 requires annual inspections for the first 5 years after closure and once every 5 years thereafter for a total of 30 years. The site has been inspected annually for the past 5 years and will not be inspected again until 2016.

\section{CAU 333, U-3auS Disposal Site}

One CAS in CAU 333 requires inspection. CAS 03-16-01 was inspected on November 8, 2011. Minor fence repair was required. Fence maintenance will be completed in 2012. No other issues were identified.

CAS 03-16-01 requires inspection every 5 years until 2026. The site will not be inspected again until 2016.

\section{CAU 357, Mud Pits and Waste Dump}

Three CASs in CAU 357 require inspections. CAS 04-26-03 and CAS 10-09-06 were inspected on November 1, 2011. CAS 25-15-01 was inspected on December 19, 2011. No issues were identified, and no maintenance or repairs were required.

\section{CAU 528, Polychlorinated Biphenyls Contamination}

One CAS in CAU 528 requires inspection. CAS 25-27-03 was inspected on December 19, 2011. Three signs were down; three signs were loose, and one T-post was damaged. Sign and T-post maintenance will be completed in 2012. No other issues were identified.

CAS 25-27-03 requires annual inspections for the first 5 years after closure and once every 5 years thereafter for a total of 30 years. The site has been inspected annually for the past 5 years and will not be inspected again until 2016.

\section{CAU 529, Area 25 Contaminated Materials}

One CAS in CAU 529 requires inspection. CAS 25-23-17 was inspected on December 19, 2011. During the previous inspections performed for Calendar Year 2010, two signs were missing, and minor fence repair was required. Sign and fence maintenance were completed in May 2011. 
During the 2011 inspection, two missing signs needed to be replaced. Sign maintenance will be completed in 2012. No other issues were identified.

\section{CAU 539, Areas 25 and 26 Railroad Tracks}

One CAS in CAU 539 requires inspection. CAS 25-99-21 was inspected on December 19, 2011. No issues were identified, and no maintenance or repairs were required.

\section{CAU 542, Disposal Holes}

Five CASs in CAU 542 require inspections. CAS 03-20-07, CAS 03-20-09, CAS 03-20-10, CAS 03-20-11, and CAS 06-20-03 were inspected on November 8, 2011. During the previous inspections performed for Calendar Year 2010, several faded signs needed to be replaced at CAS 03-20-09, CAS 03-20-10, and CAS 06-20-03. Sign maintenance was completed in May 2011. During the 2011 inspections, no issues were identified, and no maintenance or repairs were required.

\section{CAU 543, Liquid Disposal Units}

Three CASs in CAU 543 require inspections. CAS 06-07-01 was inspected on November 8, 2011. CAS 15-01-03 and CAS 15-23-03 were inspected on October 27, 2011. During the previous inspections performed for Calendar Year 2010, three signs were missing and minor fence repair was required at CAS 15-01-03 and CAS 15-23-03. Sign and fence maintenance was completed in April 2011. During the 2011 inspections, minor fence repair was required at CAS 06-07-01, CAS 15-01-03, and CAS 15-23-03. Fence maintenance will be completed in 2012. No other issues were identified.

\section{CAU 544, Cellars, Mud Pits, and Oil Spills}

One CAS in CAU 544 requires inspection. CAS 20-25-04 was inspected on October 18, 2011. Two T-posts were damaged, and minor fence repair was required. T-post and fence maintenance will be completed in 2012. No other issues were identified.

\section{CAU 545, Dumps, Waste Disposal Sites, and Buried Radioactive Materials}

Two CASs in CAU 545 require inspections. CAS 03-08-03 and CAS 03-23-05 were inspected on November 8, 2011. Several faded signs needed to be replaced at CAS 03-08-03 and CAS 03-23-05, and minor fence repair were required at CAS 03-08-03. Sign and fence maintenance will be completed in 2012. No other issues were identified.

\section{CAU 546, Injection Well and Surface Releases}

One CAS in CAU 546 requires inspection. CAS 09-20-01 was inspected on October 27, 2011. No issues were identified, and no maintenance or repairs were required.

\section{CAU 551, Area 12 Muckpiles}

Four CASs in CAU 551 require inspections. CAS 12-01-09, CAS 12-06-05, CAS 12-06-07, and CAS 12-06-08 were inspected on November 14, 2011. During the previous inspections performed for Calendar Year 2010, two signs were down, and one faded sign needed to be replaced. 
Sign maintenance was completed in May 2011. During the 2011 inspections, four faded signs and one missing sign needed to be replaced. Sign maintenance will be completed in 2012. No other issues were identified.

CAU 552, Area 12 Muckpile and Ponds

One CAS in CAU 552 requires inspection. CAS 12-23-05 was inspected on October 18, 2011. One sign was loose. Sign maintenance will be completed in 2012. No other issues were identified.

\section{CAU 554, Area 23 Release Site}

One CAS in CAU 554 requires inspection. CAS 23-02-08 was inspected on December 12, 2011. No issues were identified, and no maintenance or repairs were required.

\section{CAU 560, Septic Systems}

Two CASs in CAU 560 require inspections. CAS 06-05-03 and CAS 06-05-04 were inspected on November 8,2011. One missing sign and one damaged sign needed to be replaced. Sign maintenance will be completed in 2012. No other issues were identified.

\section{CAU 561, Waste Disposal Areas}

One CAS in CAU 561 requires inspection. CAS 02-08-02 was inspected on October 24, 2011. No issues were identified, and no maintenance or repairs were required.

\section{CAU 566, EMAD Compound}

One CAS in CAU 566 requires inspection. CAS 25-99-20 was inspected on December 19, 2011. No issues were identified, and no maintenance or repairs were required.

\section{SOILS SITES}

The following use restricted sites were closed under the Soils Activity.

\section{CAU 107, Low Impact Soil Sites}

Two CASs in CAU 107 require inspections. CAS 03-23-29 was inspected on November 8, 2011. CAS 18-23-02 was inspected on October 3, 2011. During the previous inspections performed for Calendar Year 2010, minor fence repair was required at CAS 03-23-29. Fence maintenance was completed in May 2011. During the 2011 inspection, no issues were identified, and no maintenance or repairs were required.

\section{CAU 365, Baneberry Contamination Area}

One CAS in CAU 365 requires inspection. CAS 08-23-02 was inspected on November 1, 2011. No issues were identified, and no maintenance or repairs were required.

\section{CAU 367, Area 10 Sedan, Ess and Uncle Unit Craters}

Three CASs in CAU 367 require inspections. CAS 10-45-01, CAS 10-45-02, and CAS 10-45-03 were inspected on October 27, 2011. No issues were identified, and no maintenance or repairs were required. 


\section{CAU 370, T-4 Atmospheric Test Site}

One CAS in CAU 370 requires inspection. CAS 04-23-01 was inspected on November 14, 2011. During the previous inspections performed for Calendar Year 2010, two signs were down, and minor fence repair was required. Sign and fence maintenance was completed in April and November 2011. During the 2011 inspections, seven signs were down, one sign was loose, and minor fence repair was required. Sign and fence maintenance will be completed in 2012 . No other issues were identified.

\section{CAU 371, Johnnie Boy Crater and Pin Stripe}

Two CASs in CAU 371 require inspections. CAS 11-23-05 was inspected on November 14, 2011. CAS 18-45-01 was inspected on October 3, 2011. Several signs needed to be replaced at CAS 11-23-05. Sign maintenance will be completed in 2012. No other issues were identified.

\section{CAU 372, Area 20 Cabriolet/Palanquin Unit Craters}

Four CASs in CAU 372 require inspections. CAS 18-45-02 and CAS 18-45-03 were inspected on October 3, 2011. CAS 20-23-01 and CAS 20-45-01 were inspected on October 6, 2011. Minor fence repair was required at CAS 18-45-02 and CAS 18-45-03, one sign was loose at CAS 18-45-03, and two T-posts were damaged at CAS 18-45-03. Sign, fence, and T-post maintenance will be completed in 2012. No other issues were identified.

\section{CAU 374, Area 20 Schooner Unit Crater}

Two CASs in CAU 374 require inspections. CAS 18-23-01 was inspected on October 3, 2011. CAS 20-45-03 was inspected on October 6, 2011. Minor fence repair was required at CAS 18-23-01. Fence maintenance will be completed in 2012. No other issues were identified.

\section{CAU 375, Area 30 Buggy Unit Craters}

Two CASs in CAU 375 require inspections. CAS 25-23-22 was inspected on December 20, 2011. CAS 30-45-01 was inspected on October 3, 2011. One T-post was loose and minor fence repair was required at CAS 30-45-01. Sign and fence maintenance will be completed in 2012. No other issues were identified.

\section{DEFENSE THREAT REDUCTION AGENCY (DTRA) SITES}

The following use restricted sites were closed by DTRA. Results of these inspections are included in this report on behalf of DTRA.

\section{CAU 383, Area 12 E-Tunnel Sites}

Three CASs in CAU 383 require inspections. CAS 12-06-06, CAS 12-25-02, and CAS 12-28-02 were inspected on November 14, 2011. One sign was down and minor fence repair was required. Sign and fence maintenance will be completed in 2012. No other issues were identified.

CAU 476, Area 12 T-Tunnel Muckpile, and CAU 559, T-Tunnel Compressor/Blower Pad One CAS in CAU 476 and one CAS in CAU 559 require inspection. The sites are co-located and reported on a single inspection checklist. CAS 12-06-02 and CAS 12-25-13 were inspected on October 19, 2011. No issues were identified, and no maintenance or repairs were required. 


\section{CAU 477, Area 12 N-Tunnel Muckpile}

One CAS in CAU 477 requires inspection. CAS 12-06-03 was inspected on October 18, 2011. During the previous inspections performed for Calendar Year 2010, it was noted that the wording on the sign had been altered. Sign maintenance was completed in April 2011. During the 2011 inspection, no issues were identified, and no maintenance or repairs were required.

\section{CAU 478, Area 12 T-Tunnel Ponds}

One CAS in CAU 478 requires inspection. CAS 12-23-01 was inspected on October 19, 2011. During the previous inspections performed for Calendar Year 2010, minor fence repair was required. Fence maintenance was completed in May 2011. During the 2011 inspection, no issues were identified, and no maintenance or repairs were required.

\section{CAU 482, Area 15 U15a/e Muckpiles and Ponds}

Three CASs in CAU 482 require inspections. CAS 15-06-01, CAS 15-06-02, and CAS 15-38-01 were inspected on October 27, 2011. No issues were identified, and no maintenance or repairs were required.

Copies of completed inspection checklists are enclosed. Please direct comments and questions to Tiffany Lantow, of my staff, at (702) 295-7645.

ERP:8567.TL

/s/: Robert F. Boehlecke

Robert F. Boehlecke

Environmental Management

Operations Activity Manager

Enclosures:

As stated 
cc w/encl:

J. J. MacDougall, NDEP, Las Vegas, NV (2 electronic copies)

Northern Nevada Public Reading Facility, Carson City, NV (1 electronic copy)

Southern Nevada Public Reading Facility, Las Vegas, NV (2 electronic copies)

R. A. King, NSTec, Las Vegas, NV

NSTec STI Point of Contact, MS NLV051 (electronic copy to OSTI)

NSTec Correspondence Control, MS NLV008

Technical Library, NNSA/NSO, Las Vegas, NV (electronic copy)

cc w/o encl:

J. T. Fraher, DTRA/CXTS, Kirtland AFB, NM

H. S. Page, NDEP, Las Vegas, NV

T. M. Zaferatos, NDEP, Las Vegas, NV

N-I Central Files, MS NSF 156

T. A. Lantow, ERP, NNSA/NSO, Las Vegas, NV

FFACO Group, PSG, NNSA/NSO, Las Vegas, NV

NNSA/NSO Read File 
Nevada

Environmental Management

Operations Activity

ENCLOSURE:
INSPECTION CHECKLISTS

Post-Closure Inspection

Letter Report for Corrective

Action Units on the Nevada

National Security Site

Calendar Year 2011

May 2012

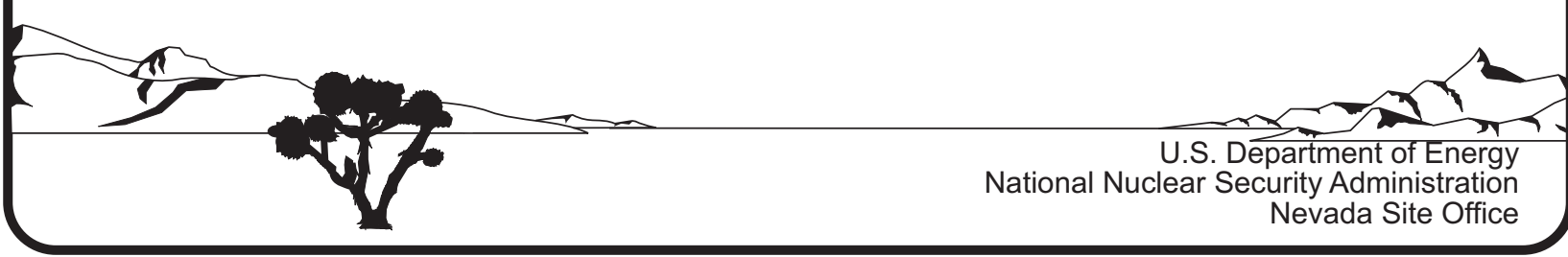


THIS PAGE INTENTIONALLY LEFT BLANK 
CAU 5: LANDFILLS 
THIS PAGE INTENTIONALLY LEFT BLANK 
Inspection Requirement: Annual (through December 2011) then Every 5 Years (through December 2036)

POST-CLOSURE INSPECTION CHECKLIST

\section{CAU 5, LANDFILLS - CAS 05-15-01, SANITARY LANDFILL}

\begin{tabular}{|c|c|c|}
\hline Inspection Date and Time: $/ / / 8$ & $11 \quad 3: 25 \mathrm{pm}$ & Reason for Inspection: \\
\hline Date of Last Post-Closure Inspection: & $11 / 22 / 10$ & Reason for Last Post-Closure Inspection: A n $\mathrm{n}$ ceal \\
\hline
\end{tabular}

Responsible Entity: NSTec Environmental Restoration, Nevada National Security Site, Mercury, Nevada

Responsible Facility Owner: Thomas A. Thiele, Project Manager, Industrial Sites, Environmental Restoration Project

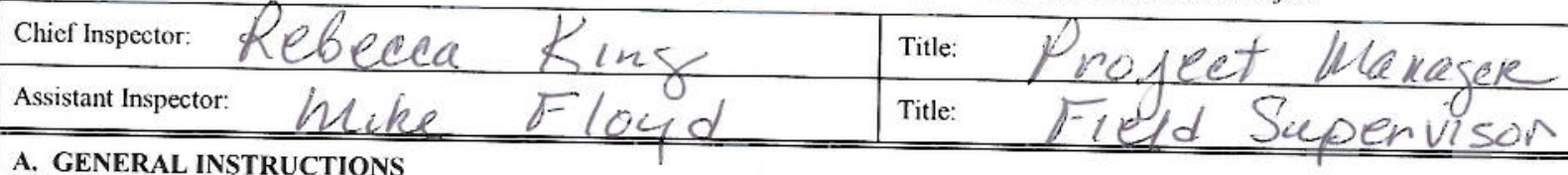

\section{A. GENERAL INSTRUCTIONS}

- Complete all checklist items.

- If a SHADED BOX is checked, provide detailed information and/or appropriate references to other documents that have the information.

- All documentation must be legible and clear

\begin{tabular}{|c|c|c|c|}
\hline B. PREPARATION (To be completed prior to site visit) & YES & NO & EXPLANATION (required if shaded box is checked) \\
\hline \multicolumn{4}{|l|}{ 1. Has the Post-Closure Plan been reviewed? } \\
\hline 2. Have the previous inspection reports been reviewed? & & & \\
\hline \multicolumn{4}{|l|}{ 3. Were anomalies or trends detected on previous inspections? } \\
\hline $\begin{array}{l}\text { 4. Were maintenance or repair activities perfonmed since the last } \\
\text { inspection? }\end{array}$ & & & $\begin{array}{l}\text { Wh sigks pehaing * Taposts } \\
\text { nepared }\end{array}$ \\
\hline $\begin{array}{l}\text { a. If yes, has site repair resulted in a change from as-built } \\
\text { conditions? }\end{array}$ & & $v$ & 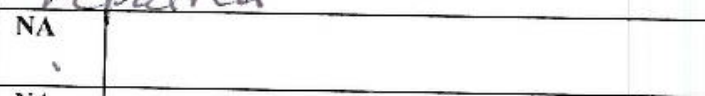 \\
\hline $\begin{array}{l}\text { b. If yes (to } 4 \mathrm{a} \text { ), are revised as-built plans available that reflect } \\
\text { repair changes? }\end{array}$ & & & NA \\
\hline
\end{tabular}

\section{SITE INSPECTION PREPARATION}

Assemble the following, as needed, to conduct inspections:

- Radio, pager, etc.

- Previous letter report, inspection checklists, repair records, and as-built plans

- Camera, digital storage drive, extra batteries, and other miscellaneous support equipment

\section{SITE INSPECTION}

- The site inspection is a walking inspection of the entire site including the perimeter and sufficient transects to be able to inspect the entire surface and all features specifically described in this checklist. The checklist should be completed during the site inspection.

- If a shaded box is checked, add detailed comments to document the results of the site inspection. Information provided should be of sufficient detail to enable reconstruction of observations regarding field conditions. The completed checklist is part of the field record of the inspection. - Field notes taken to assist in completion of this checklist will become part of the inspection record. No form is specified for field notes, and additional
field notes are not required if the checklist and associated attachments adequately describe site conditions.

1. Site Markers:

a. Have any posts been damaged or their anchoring weakened?

b. Are all use restriction signs legible?

c. Are any of the 11 use restriction signs damaged or missing?

d. How many damaged or missing signs need to be replaced?

e. Are any use restriction signs down?

f. How many down signs need to be re-hung?

\begin{tabular}{|r|r|l||}
\hline YES & NO & EXPLANATION (required if shaded box is checked) \\
\hline & $\checkmark$ & \\
\hline$\checkmark$ & & \\
\hline & $\checkmark$ & \\
\hline 0 & \\
\hline & $J$ & \\
\hline$O$ & $R$ & \\
\hline
\end{tabular}


Inspection Requirement: Annual (through December 2011) then Every 5 Years (through December 2036)

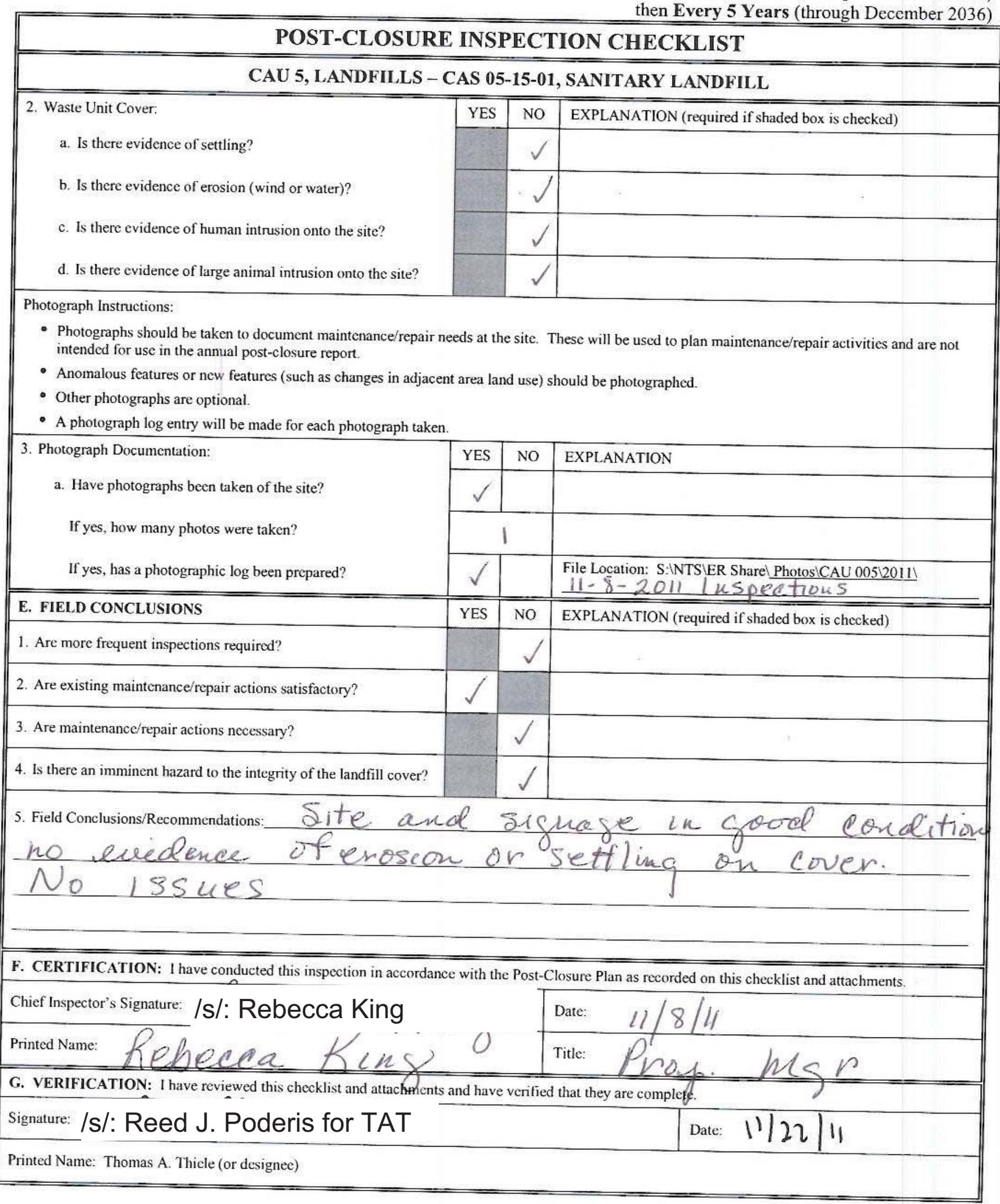




\section{POST-CLOSURE INSPECTION CHECKLIST}

\section{CAU 5, LANDFILLS - CAS 05-16-01, LANDFILL}

\begin{tabular}{|c|c|c|}
\hline Inspection Date and Time: $1 / / 14$ & $11: 05$ & Reason for Inspection: \\
\hline Date of Last Post-Closure Inspection & $2 2 \longdiv { 1 0 }$ & Reason for Last Post-Closure Inspection: $f t$ in $n<A$ \\
\hline
\end{tabular}

Responsible Entity: NSTec Environmental Restoration, Nevada National Security Site, Mercury, Nevada

Responsible Facility Owner: Thomas A. Thiele, Project Manager, Industrial Sites, Environmental Restoration Project

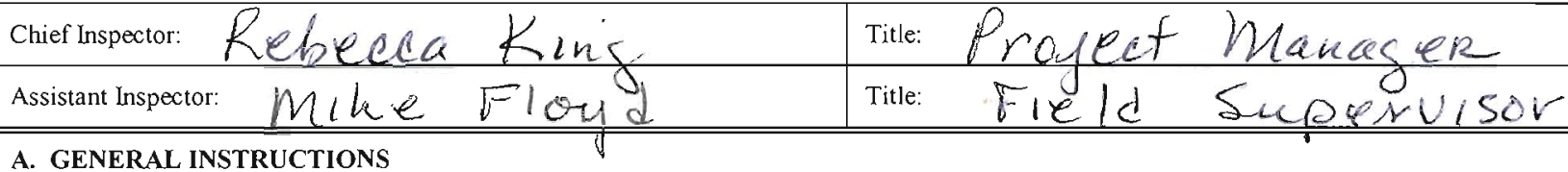

- Complete all checklist items.

- If a SHADED BOX is checked, provide detailed information and/or appropriate references to other documents that have the information.

- All documentation must be legible and clear.

B. PREPARATION (To be completed prior to site visit)

I. Has the Post-Closure Plan been reviewed?

2. Have the previous inspection reports been reviewed?

3. Were anomalies or trends detected on previous inspections?

4. Were maintenance or repair activities performed since the last inspection?

a. If yes, has site repair resulted in a change from as-built conditions?

b. If yes (to $4 a$ ), are revised as-built plans available that reflect repair changes?

\section{SITE INSPECTION PREPARATION}

Assemble the following, as needed, to conduct inspections:

- Pre-arrange access to the site with the Area 5 RWMS 1 week prior to the inspection so the activity can be added to their Plan of the Day

- Radio, pager, etc

- Previous letter report, inspection checklists, repair records, and as-built plans

- Camera, digital storage drive, extra batteries, and other miscellaneous support equipment

\section{SITE INSPECTION}

- The site inspection is a walking inspection of the entire site including the perimeter and sufficient transects to be able to inspect the entire surface and all features specifically described in this checklist. The checklist should be completed during the site inspection.

- If a shaded box is checked, add detailed comments to document the results of the site inspection. Information provided should be of sufficient detail to enable reconstruction of observations regarding field conditions. The completed checklist is part of the field record of the inspection.

- Field notes taken to assist in completion of this checklist will become part of the inspection record. No form is specified for field notes, and additional field notes are not required if the checklist and associated attachments adequately describe site conditions.

1. Site Markers East of Berm:

a. Have any sign posts been damaged or their anchoring weakened?

b. Are all use restriction signs legible?

c. Are any use restriction signs damaged or missing?

d. How many damaged or missing signs need to be replaced?

e. Are any use restriction signs down?

f. How many down signs need to be re-hung?

\begin{tabular}{|c|c|c||}
\hline YES & NO & EXPLANATION (required if shaded box is checked) \\
\hline & $\checkmark$ & \\
\hline & & \\
\hline & $\checkmark$ & \\
\hline & & \\
\hline & $J$ & \\
\hline 0 & \\
\hline
\end{tabular}




\begin{tabular}{|c|c|c|c|}
\hline \multicolumn{4}{|c|}{ POST-CLOSURE INSPECTION CHECKLIST } \\
\hline \multicolumn{4}{|c|}{ CAU 5, LANDFILLS - CAS 05-16-01, LANDFILL } \\
\hline 2. Waste Unit Cover East of Berm: & YES & NO & EXPLANATION (required if shaded box is checked) \\
\hline a. Is there evidence of settling? & & & \\
\hline b. Is there evidence of erosion (wind or water)? & & & \\
\hline c. Is there evidence of human intrusion onto the site? & & & \\
\hline d. Is there evidence of large animal intrusion onto the site? & & $\checkmark$ & \\
\hline 3. Site Markers West of Berm: & YES & NO & EXPLANATION (required if shaded box is checked) \\
\hline a. Is there damage to the fence? & & $\checkmark$ & \\
\hline $\begin{array}{l}\text { b. Have any posts been damaged or their anchoring } \\
\text { weakened? }\end{array}$ & & $\sqrt{ }$ & \\
\hline c. Are all use restriction signs legible? & $\checkmark$ & & \\
\hline d. Are any use restriction signs damaged or missing? & & $\checkmark$ & \\
\hline e. How many damaged or missing signs need to be replaced? & & & \\
\hline f. Are any use restriction signs down? & & & \\
\hline g. How many down signs need to be re-hung? & & 0 & \\
\hline 4. Waste Unit Cover West of Berm: & YES & NO & EXPLANATION (required if shaded box is checked) \\
\hline a. Is there evidence of settling? & & & \\
\hline b. Is there evidence of erosion (wind or water)? & & & \\
\hline c. Is there evidence of human intrusion onto the site? & & $\sqrt{ }$ & \\
\hline d. Is there evidence of large animal intrusion onto the site? & & $\checkmark$ & \\
\hline $\begin{array}{l}\text { Photograph Instructions: } \\
\text { - Photographs should be taken to document maintenance/repair } \\
\text { intended for use in the annual post-closure report. } \\
\text { - Anomalous features or new features (such as changes in adjac } \\
\text { - Other photographs are optional. } \\
\text { - A photograph log entry will be made for each photograph take }\end{array}$ & tarea la & site. & $\begin{array}{l}\text { lese will be used to plan maintenance/repair activities and are not } \\
\text { ould be photographed. }\end{array}$ \\
\hline 5. Photograph Documentation: & YES & NO & EXPLANATION \\
\hline a. Have photographs been taken of the site? & $\mathcal{J}$ & & \\
\hline If yes, how many photos were taken? & $R_{i}^{f} p_{1}^{R}$ & & \\
\hline If yes, has a photographic log been prepared? & $\checkmark$ & & $\begin{array}{l}\text { File Location: S:WTSIER SharelPhotosi (ALI00S) } \\
2011 \text {. }\end{array}$ \\
\hline E. FIELD CONCLUSIONS & YES & NO & EXPLANATION (required if shaded box is checked) \\
\hline 1. Are more frequent inspections required? & & & \\
\hline 2. Are existing maintenance/repair actions satisfactory? & $\checkmark$ & & \\
\hline 3. Are maintenance/repair actions necessary? & & $\sqrt{ }$ & \\
\hline 4. Is there an imminent hazard to the integrity of the landfill cover? & & $\sqrt{ }$ & \\
\hline
\end{tabular}




\begin{tabular}{|c|c|}
\hline \multicolumn{2}{|c|}{ POST-CLOSURE INSPECTION CHECKLIST } \\
\hline \multicolumn{2}{|c|}{ CAU 5, LANDFILLS - CAS 05-16-01, LANDFILL } \\
\hline \multicolumn{2}{|c|}{ 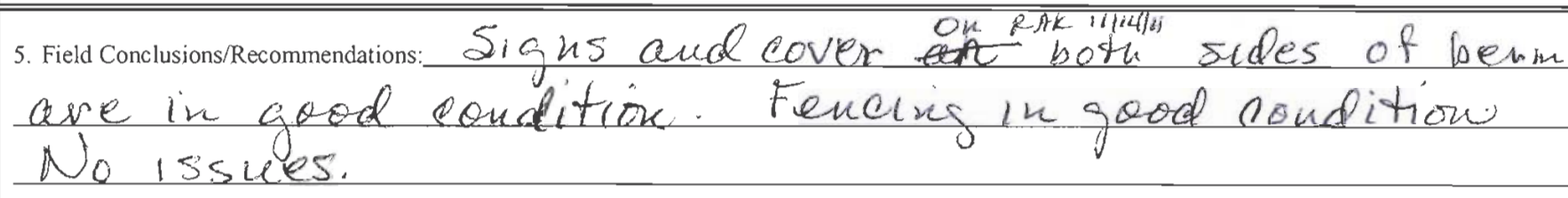 } \\
\hline \multicolumn{2}{|c|}{ F. CERTIFICATION: I have conducted this inspection in accordance with the Post-Closure Plan as recorded on this checklist and attachments. } \\
\hline Chief Inspector's Signature: /s/: Rebecca King & Date: $11 / 14111$ \\
\hline Printed Name: Kebecea King & Title: jisoneet Manage. \\
\hline \multicolumn{2}{|c|}{ G. VERIFICATION: I have reviewed this checklist and attachments and have verified that they are complete } \\
\hline Signature: /s/: Reed J. Poderis for TAT & Date: $11 / 28 / 11$ \\
\hline Printed Name: Thomas A. Thiele (or designee) & \\
\hline
\end{tabular}


THIS PAGE INTENTIONALLY LEFT BLANK 
Inspection Requirement: Annual (through December 2011) then Every 5 Years (through December 2036)

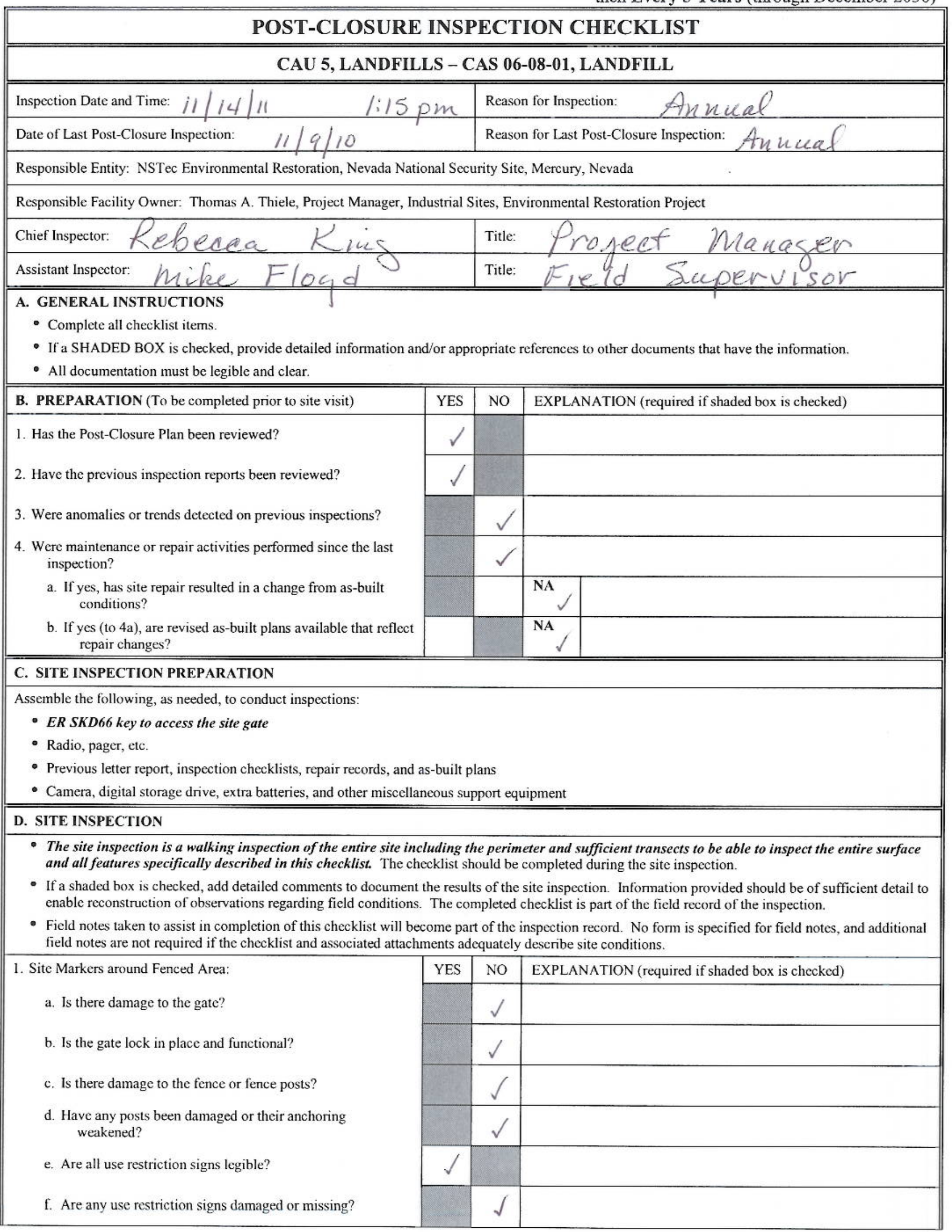


Inspection Requirement: Annual (through December 2011) then Every 5 Years (through December 2036)

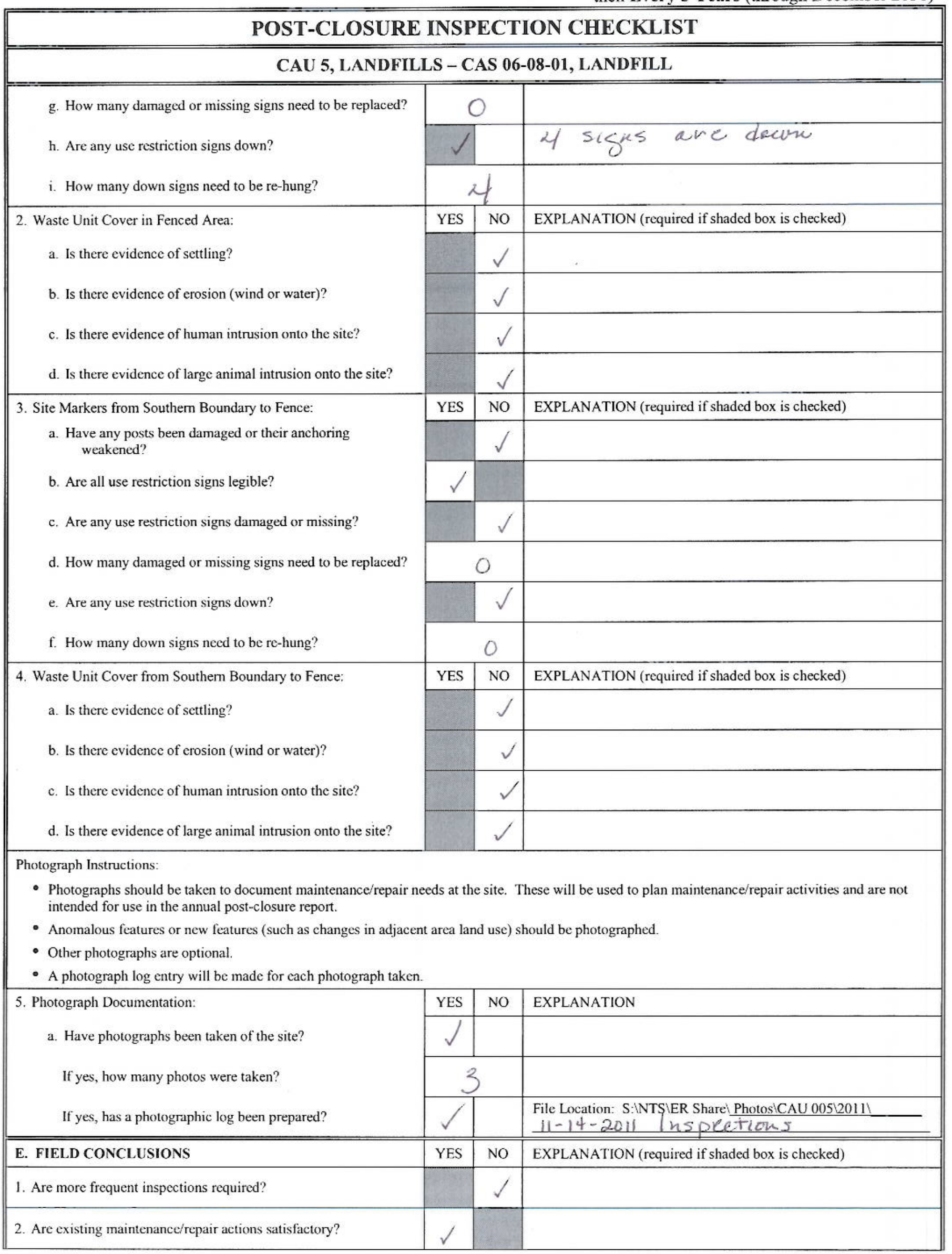

Page 2 of 3 
Inspection Requirement: Annual (through December 2011) then Every 5 Years (through December 2036)

\begin{tabular}{|c|c|}
\hline \multicolumn{2}{|c|}{ POST-CLOSURE INSPECTION CHECKLIST } \\
\hline \multicolumn{2}{|c|}{ CAU 5, LANDFILLS - CAS 06-08-01, LANDFILL } \\
\hline 3. Are maintenance/repair actions necessary? & 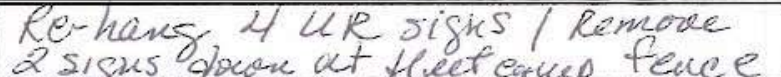 \\
\hline 4. Is there an imminent hazard to the integrity of the landfill cover? & \\
\hline \multirow{2}{*}{\multicolumn{2}{|c|}{ 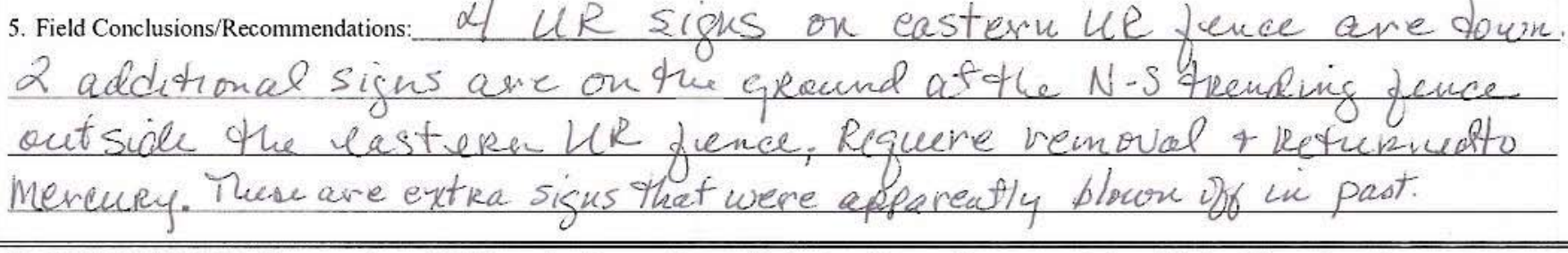 }} \\
\hline & \\
\hline \multicolumn{2}{|c|}{ F. CERTIFICATION: I have conducted this inspection in accordance with the Post-Closure Plan as recorded on this checklist and attachments. } \\
\hline Chief Inspector's Signature: /s/: Rebecca King & Date: $11 / 14 / 11$ \\
\hline Printed Name: Refecea Kins & Mavaser \\
\hline G. VERIFICATION: I have reviewed this checklist and attachmen & that they are complete? \\
\hline Signature: /s/: Reed J. Poderis for TAT & Date: $\quad 11 / 2 / / 1$ \\
\hline
\end{tabular}


THIS PAGE INTENTIONALLY LEFT BLANK 
Inspection Requirement: Annual (through December 2011) then Every 5 Years (through December 2036)

\section{POST-CLOSURE INSPECTION CHECKLIST}

\section{CAU 5, LANDFILLS -}

CAS 06-15-02, SANITARY LANDFILL, AND CAS 06-15-03, SANITARY LANDFILL, BURN PIT

\begin{tabular}{|ll|l|}
\hline \hline Inspection Date and Time: $1 / / 8 / 11$ & $2: 10 \mathrm{pm}$ & Reason for Inspection: An hucal \\
\hline Date of Last Post-Closure Inspection: $11 / 9 / 10$ & Reason for Last Post-Closure Inspection: Ann ual \\
\hline
\end{tabular}

Responsible Entity: NSTec Environmental Restoration, Nevada National Security Site, Mercury, Nevada

Responsible Facility Owner: Thomas A. Thiele, Project Manager, Industrial Sites, Environmental Restoration Project

\begin{tabular}{|c|c|c|}
\hline Chief Inspector: & 89 & Title: $\quad P_{p}$ \\
\hline Assistant Inspector: & Mine Flocid & Title: Fied sucoenvison \\
\hline
\end{tabular}

A. GENERAL INSTRUCTIONS

- Complete all checklist items.

- If a SHADED BOX is checked, provide detailed information and/or appropriate references to other documents that have the information.

- All documentation must be legible and clear.

\begin{tabular}{|c|c|c|c|}
\hline B. PREPARATION (To be completed prior to site visit) & YES & NO & EXPLANATION (required if shaded box is checked) \\
\hline \multicolumn{4}{|l|}{ 1. Has the Post-Closure Plan been reviewed? } \\
\hline \multicolumn{4}{|l|}{ 2. Have the previous inspection reports been reviewed? } \\
\hline \multicolumn{4}{|l|}{ 3. Were anomalies or trends detected on previous inspections? } \\
\hline \multicolumn{4}{|l|}{$\begin{array}{l}\text { 4. Were maintenance or repair activities performed since the last } \\
\text { inspection? }\end{array}$} \\
\hline $\begin{array}{l}\text { a. If yes, has site repair resulted in a change from as-built } \\
\text { conditions? }\end{array}$ & & & NA \\
\hline $\begin{array}{l}\text { b. If yes (to } 4 \mathrm{a} \text { ), are revised as-built plans available that reflect } \\
\text { repair changes? }\end{array}$ & & & $\mathrm{NA}_{\mathrm{N}}$ \\
\hline
\end{tabular}

\section{SITE INSPECTION PREPARATION}

Assemble the following, as needed, to conduct inspections:

- Radio, pager, etc.

- Previous letter report, inspection checklists, repair records, and as-built plans

- Camera, digital storage drive, extra batteries, and other miscellaneous support equipment

\section{SITE INSPECTION}

- The site inspection is a walking inspection of the entire site including the perimeter and sufficient transects to be able to inspect the entire surface and all features specifically described in this checklist. The checklist should be completed during the site inspection.

- If a shaded box is checked, add detailed comments to document the results of the site inspection. Information provided should be of sufficient detail to enable reconstruction of observations regarding field conditions. The completed checklist is part of the field record of the inspection.

- Field notes taken to assist in completion of this checklist will become part of the inspection record. No form is specified for field notes, and additional field notes are not required if the checklist and associated attachments adequately describe site conditions.

1. Site Markers:

a. Have any posts been damaged or their anchoring weakened?

b. Are all use restriction signs legible?

c. Are any use restriction signs damaged or missing?

d. How many damaged or missing signs need to be replaced?

e. Are any use restriction signs down?

f. How many down signs need to be re-hung?

\begin{tabular}{|c|c|c|}
\hline YES & NO & EXPLANATION (required if shaded box is checked) \\
\hline$\sqrt{ }$ & & $\begin{array}{l}\text { I sigu douk with I post out of } \\
\text { around }\end{array}$ \\
\hline$\sqrt{ }$ & & \\
\hline & $\sqrt{ }$ & \\
\hline & 0 in & Ak \\
\hline 1 & (2+1) & $\begin{array}{l}\text { I sighdown-see 1. a above and } \\
\text { isign down but posts still ingkac }\end{array}$ \\
\hline
\end{tabular}


Inspection Requirement: Annual (through December 2011) then Every 5 Years (through December 2036)

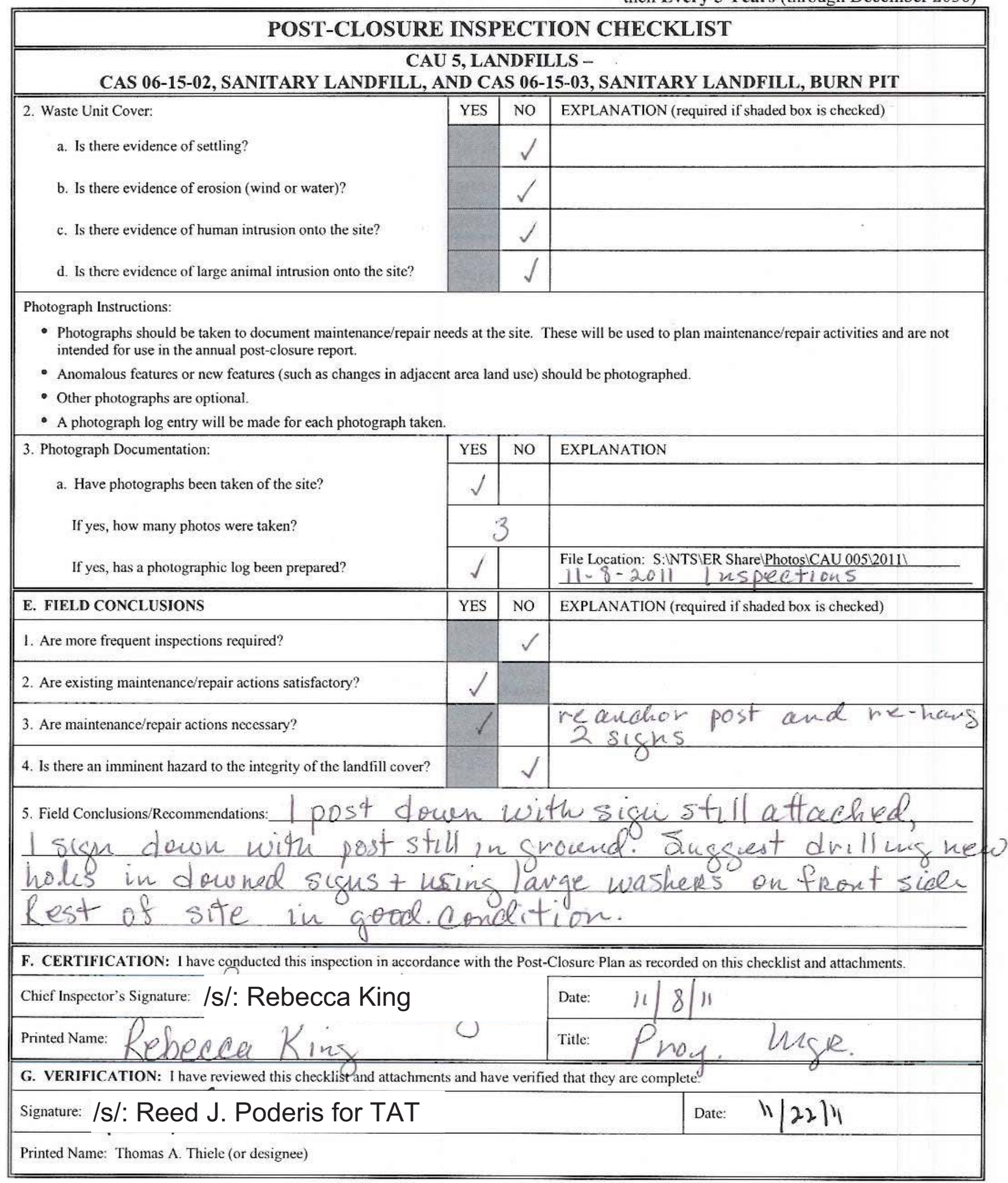




\begin{tabular}{|c|c|c|c|}
\hline \multicolumn{4}{|c|}{ POST-CLOSURE INSPECTION CHECKLIST } \\
\hline \multicolumn{4}{|c|}{ CAU 5, LANDFILLS - CAS 12-15-01, SANITARY LANDFILL } \\
\hline \multicolumn{2}{|l|}{ Inspection Date and Time: $10 / 18 / 11 \quad i 430$} & \multicolumn{2}{|c|}{ Reason for Inspection: Ank ual } \\
\hline \multicolumn{2}{|l|}{ Date of Last Post-Closure Inspection: $10 / 11 / 10$} & \multicolumn{2}{|c|}{ Reason for Last Post-Closure Inspection: An 4 L C } \\
\hline \multicolumn{4}{|c|}{ Responsible Entity: NSTec Environmental Restoration, Nevada National Security Site, Mercury, Nevada } \\
\hline \multicolumn{4}{|c|}{ Responsible Facility Owner: Thomas A. Thiele, Project Manager, Industrial Sites, Environmental Restoration Project } \\
\hline \multicolumn{2}{|l|}{ Chief Inspector: Kebeepa Xixs } & \multicolumn{2}{|c|}{ Title: Peoseet Manaser } \\
\hline \multicolumn{2}{|l|}{ Assistant Inspector: Kander Ipaces dx } & \multicolumn{2}{|c|}{ Title: haborepe } \\
\hline \multicolumn{4}{|c|}{$\begin{array}{l}\text { A. GENERAL INSTRUCTIONS } \\
\text { - Complete all checklist items. } \\
\text { - If a SHADED BOX is checked, provide detailed information and/or appropriate references to other documents that have the information. } \\
\text { - All documentation must be legible and clear. }\end{array}$} \\
\hline B. PREPARATION (To be completed prior to site visit) & YES & NO & EXPLANATION (required if shaded box is checked) \\
\hline \multicolumn{4}{|l|}{ 1. Has the Post-Closure Plan been reviewed? } \\
\hline \multicolumn{4}{|l|}{ 2. Have the previous inspection reports been reviewed? } \\
\hline \multicolumn{4}{|l|}{ 3. Were anomalies or trends detected on previous inspections? } \\
\hline \multirow{3}{*}{$\begin{array}{l}\text { 4. Were maintenance or repair activities performed since the last } \\
\text { inspection? } \\
\text { a. If yes, has site repair resulted in a change from as-built } \\
\quad \text { conditions? } \\
\text { b. If yes (to } 4 \text { a), are revised as-built plans available that reflect } \\
\text { repair changes? }\end{array}$} & & & Sight fence munktinanee \\
\hline & & $\checkmark$ & 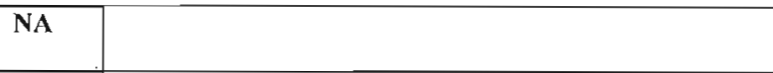 \\
\hline & & & $\stackrel{\text { NA }}{2}$ \\
\hline \multicolumn{4}{|l|}{ C. SITE INSPECTION PREPARATION } \\
\hline \multicolumn{4}{|c|}{$\begin{array}{l}\text { Assemble the following, as needed, to conduct inspections: } \\
\text { - ER SKD66 key to access the three site gates } \\
\text { - Radio, pager, etc. } \\
\text { - Previous letter report, inspection checklists, repair records, and as-built plans } \\
\text { - Camera, digital storage drive, extra batteries, and other miscellaneous support equipment }\end{array}$} \\
\hline \multicolumn{4}{|l|}{ D. SITE INSPECTION } \\
\hline \multicolumn{4}{|c|}{$\begin{array}{l}\text { - The site inspection is a walking inspection of the entire site including the perimeter and sufficient transects to be able to inspect the entire surface } \\
\text { and all features specifically described in this checklist. The checklist should be completed during the site inspection. } \\
\text { - If a shaded box is checked, add detailed comments to document the results of the site inspection. Information provided should be of sufficient detail to } \\
\text { enable reconstruction of observations regarding field conditions. The completed checklist is part of the field record of the inspection. } \\
\text { - Field notes taken to assist in completion of this checklist will become part of the inspection record. No form is specified for field notes, and additional } \\
\text { field notes are not required if the checklist and associated attachments adequately describe site conditions. }\end{array}$} \\
\hline \multirow{2}{*}{\multicolumn{4}{|c|}{$\begin{array}{l}\text { I. Site Markers: } \\
\text { a. Is there damage to any of the three gates? }\end{array}$}} \\
\hline & & & \\
\hline b. Are the gate locks in place and functional? & $\sqrt{ }$ & & \\
\hline c. Is there damage to the fence or fence posts? & & $\checkmark$ & \\
\hline $\begin{array}{l}\text { d. Have any sign posts been damaged or their anchoring } \\
\text { weakened? }\end{array}$ & & $\sqrt{ }$ & \\
\hline e. Are all use restriction signs legible? & 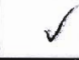 & & \\
\hline f. Are any use restriction signs damaged or missing? & & $\checkmark$ & \\
\hline g. How many damaged or missing signs need to be replaced? & & 0 & \\
\hline h. Are any use restriction signs down? & & $\gamma$ & \\
\hline i. How many down signs need to be re-hung? & & 0 & \\
\hline
\end{tabular}


Inspection Requirement: Annual (through December 2011) then Every 5 Years (through December 2036)

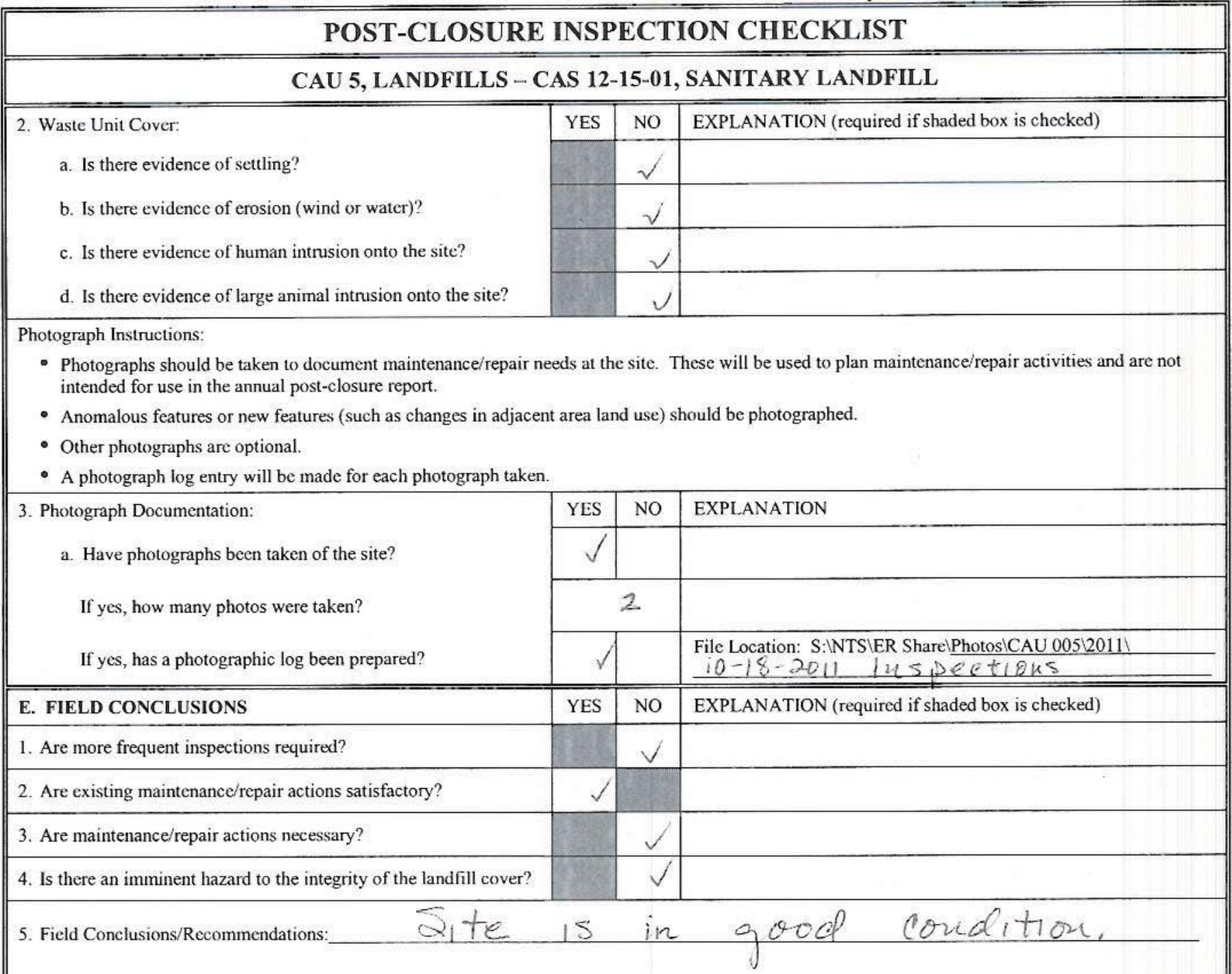

\footnotetext{
F. CERTIFICATION: I have conducted this inspection in accordance with the Post-Closure Plan as recorded on this checklist and attachments.

Chief Inspector's Signature: /s/: Rebecca King

Printed Name: $\quad$ eleca Kr $n$

G. VERIFICATION: I have reviewed this checklist and at achments and have verified that they are complete.

Signature: /s/: Reed J. Poderis for TAT $\quad$ Date: $11 / 3 / 201 /$

Printed Name: Thomas A. Thicle (or designee)
} 


\section{POST-CLOSURE INSPECTION CHECKLIST}

\section{CAU 5, LANDFILLS - CAS 20-15-01, LANDFILL}

\begin{tabular}{|l|l|l|l|l|l}
\hline \hline Inspection Date and Time: $10 / 8 / 11$ & Reason for Inspection: \\
\hline Date of Last Post-Closure Inspection: $10 / 18 / 10$ & Reason for Last Post-Closure Inspection:
\end{tabular}

Responsible Entity: NSTec Environmental Restoration, Nevada National Security Site, Mercury, Nevada

Responsible Facility Owner: Thomas A. Thiele, Project Manager, Industrial Sites, Environmental Restoration Project

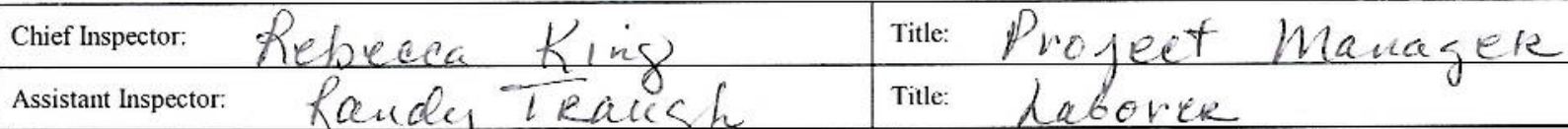

\section{A. GENERAL INSTRUCTIONS}

- Complete all checklist items.

- If a SHADED BOX is checked, provide detailed information and/or appropriate references to other documents that have the information.

- All documentation must be legible and clear.

\begin{tabular}{l|l|l|l} 
B. PREPARATION (To be completed prior to site visit) & YES & NO & EXPLANATION (required if shaded box is checked)
\end{tabular}

1. Has the Post-Closure Plan been reviewed?

2. Have the previous inspection reports been reviewed?

3. Were anomalies or trends detected on previous inspections?

4. Were maintenance or repair activities performed since the last inspection?

a. If yes, has site repair resulted in a change from as-built conditions?

b. If yes (to 4a), are revised as-built plans available that reflect repair changes?

\section{SITE INSPECTION PREPARATION}

Assemble the following, as needed, to conduct inspections:

- Radio, pager, etc.

- Previous letter report, inspection checklists, repair records, and as-built plans

- Camera, digital storage drive, extra batteries, and other miscellaneous support equipment

\section{SITE INSPECTION}

- The site inspection is a walking inspection of the entire site including the perimeter and sufficient transects to be able to inspect the entire surface and all features specifically described in this checklist. The checklist should be completed during the site inspection.

- If a shaded box is checked, add detailed comments to document the results of the site inspection. Information provided should be of sufficient detail to enable reconstruction of observations regarding field conditions. The completed checklist is part of the field record of the inspection.

- Field notes taken to assist in completion of this checklist will become part of the inspection record. No form is specified for field notes, and additional field notes are not required if the checklist and associated attachments adequately describe site conditions.

1. Site Markers:

a. Have any posts been damaged or their anchoring weakened?

b. Are all use restriction signs legible?

c. Are any use restriction signs damaged or missing?

d. How many damaged or missing signs need to be replaced?

e. Are any use restriction signs down?

f. How many down signs need to be re-hung?

\begin{tabular}{|c|c|l||}
\hline YES & NO & EXPLANATION (required if shaded box is checked) \\
\hline & $\checkmark$ & \\
\hline$\checkmark$ & & \\
\hline & $\checkmark$ & \\
\hline & 0 & \\
\hline & $\checkmark$ & \\
\hline & & \\
\hline
\end{tabular}


Inspection Requirement: Annual (through December 2011) then Every 5 Years (through December 2036)

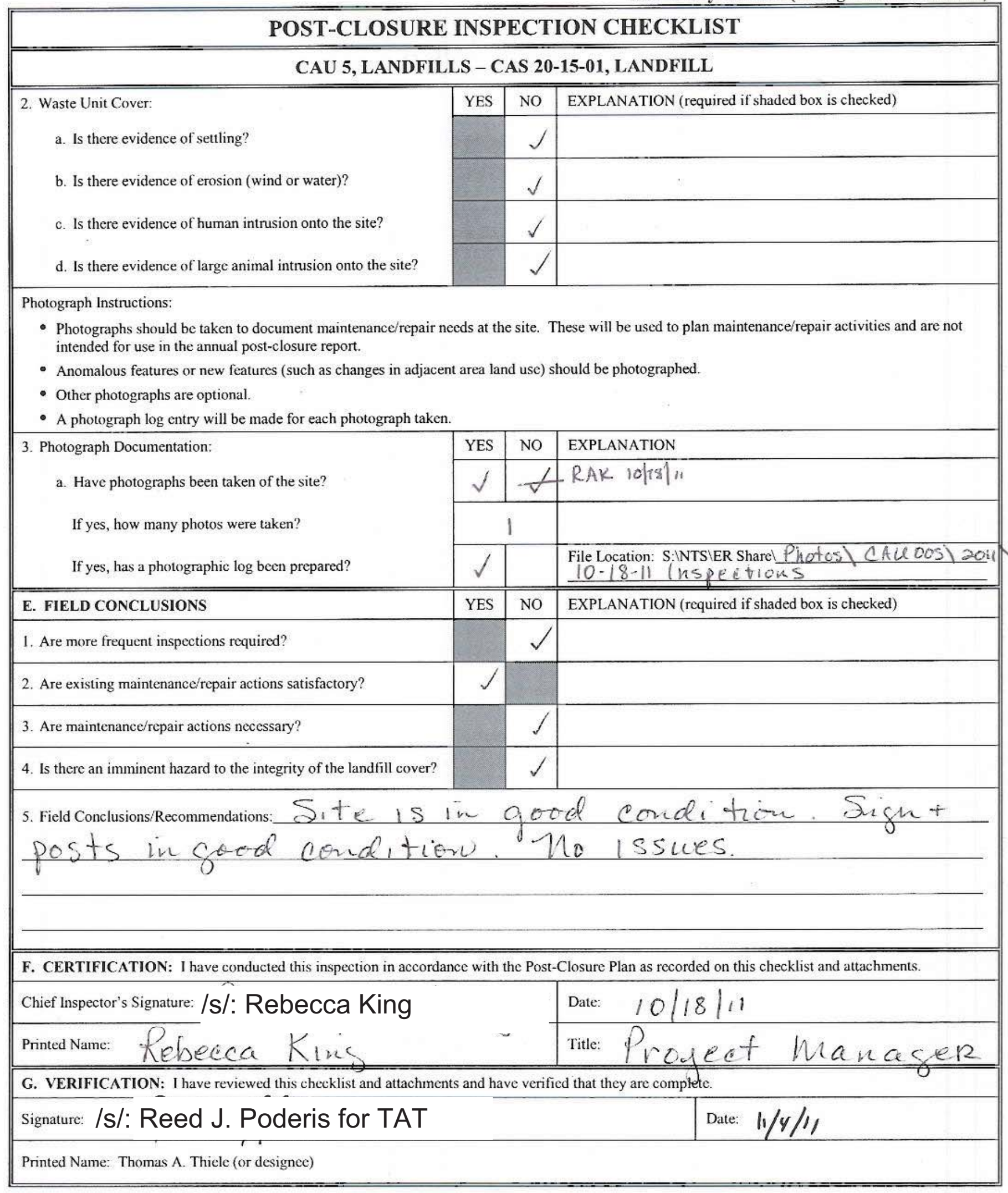


Inspection Requirement: Annual (through December 2011) then Every 5 Years (through December 2036)

\begin{tabular}{|c|c|c|c|}
\hline \multicolumn{4}{|c|}{ POST-CLOSURE INSPECTION CHECKLIST } \\
\hline \multicolumn{4}{|c|}{ CAU 5, LANDFILLS - CAS 23-15-03, DISPOSAL SITE } \\
\hline \multicolumn{2}{|c|}{ Inspection Date and Time: $12 / 12 / 11 \quad 10 \mathrm{am}$} & \multicolumn{2}{|c|}{ Reason for Inspection: $\quad A_{n}$ u } \\
\hline \multicolumn{2}{|l|}{ Date of Last Post-Closure Inspection: $\quad / / / 29 / 10$} & \multicolumn{2}{|c|}{ Reason for Last Post-Closure Inspection: A $u$ u } \\
\hline \multicolumn{4}{|c|}{ Responsible Entity: NSTec Environmental Restoration, Nevada National Security Site, Mercury, Nevada } \\
\hline \multicolumn{4}{|c|}{ Responsible Facility Owner: Thomas A. Thiele, Project Manager, Industrial Sites, Environmental Restoration Project } \\
\hline \multicolumn{2}{|l|}{ chief Inspector: $R e b e c a$ foln } & \multicolumn{2}{|c|}{ Title: Wrofect Manlesen } \\
\hline \multicolumn{2}{|l|}{ Assistant Inspector: $\quad \mathrm{AA}$} & \multicolumn{2}{|c|}{ Title: $\quad 0$} \\
\hline \multicolumn{4}{|c|}{$\begin{array}{l}\text { A. GENERAL INSTRUCTIONS } \\
\text { - Complete all checklist items. } \\
\text { - If a SHADED BOX is checked, provide detailed information and/or appropriate references to other documents that have the information. } \\
\text { - All documentation must be legible and clear. }\end{array}$} \\
\hline B. PREPARATION (To be completed prior to site visit) & YES & NO & EXPLANATION (required if shaded box is checked) \\
\hline \multicolumn{4}{|l|}{ 1. Has the Post-Closure Plan been reviewed? } \\
\hline \multicolumn{4}{|l|}{ 2. Have the previous inspection reports been reviewed? } \\
\hline \multicolumn{4}{|l|}{ 3. Were anomalies or trends detected on previous inspections? } \\
\hline \multirow{3}{*}{$\begin{array}{l}\text { 4. Were maintenance or repair activities performed since the last } \\
\text { inspection? } \\
\text { a. If yes, has site repair resulted in a change from as-built } \\
\text { conditions? } \\
\text { b. If yes (to } 4 \text { a), are revised as-built plans available that reflect } \\
\text { repair changes? }\end{array}$} & & & Sign vepair \\
\hline & & & \\
\hline & & & NA \\
\hline \multicolumn{4}{|l|}{ C. SITE INSPECTION PREPARATION } \\
\hline \multicolumn{4}{|c|}{$\begin{array}{l}\text { Assemble the following, as needed, to conduct inspections: } \\
\text { - Pre-arrange access to both the WSI Training Facility and the Area } 23 \text { Landfill } \\
\text { - Obtain key from Waste Generator Services to access the site } \\
\text { - Radio, pager, etc. } \\
\text { - Previous letter report, inspection checklists, repair records, and as-built plans } \\
\text { - Camera, digital storage drive, extra batteries, and other miscellaneous support equipment }\end{array}$} \\
\hline \multicolumn{4}{|l|}{ D. SITE INSPECTION } \\
\hline \multicolumn{4}{|c|}{$\begin{array}{l}\text { - The site inspection is a walking inspection of the entire site including the perimeter and sufficient transects to be able to inspect the entire surface } \\
\text { and all features specifically described in this checklist. The checklist should be completed during the site inspection. } \\
\text { - If a shaded box is checked, add detailed comments to document the results of the site inspection. Information provided should be of sufficient detail to } \\
\text { enable reconstluction of observations regarding field conditions. The completed checklist is part of the field record of the inspection. } \\
\text { - Field notes taken to assist in completion of this checklist will become part of the inspection record. No form is specified for field notes, and additional } \\
\text { field notes are not required if the checklist and associated attachments adequately describe site conditions. }\end{array}$} \\
\hline \multirow{2}{*}{$\begin{array}{l}\text { 1. Site Markers (Area } 23 \text { Landfill): } \\
\text { a. Have any posts been damaged or their anchoring } \\
\text { weakened? }\end{array}$} & YES & NO & EXPLANATION (required if shaded box is checked) \\
\hline & & : & 1 Lave T-post \\
\hline \multicolumn{4}{|l|}{ b. Are all use restriction signs legible? } \\
\hline c. Are any use restriction signs damaged or missing? & & $\sqrt{ }$ & \\
\hline d. How many damaged or missing signs need to be replaced? & & & \\
\hline e. Are any use restriction signs down? & & & I sign dacon \\
\hline f. How many down signs need to be re-hung? & & 1 & \\
\hline
\end{tabular}


Inspection Requirement: Annual (through December 2011) then Every 5 Years (through December 2036)

\begin{tabular}{|c|c|c|c|}
\hline \multicolumn{4}{|c|}{ POST-CLOSURE INSPECTION CHECKLIST } \\
\hline \multicolumn{4}{|c|}{ CAU 5, LANDFILLS - CAS 23-15-03, DISPOSAL SITE } \\
\hline \multirow[t]{2}{*}{ 2. Waste Unit Cover (Area 23 Landfill): } & YES & NO & EXPLANATION (required if shaded box is checked) \\
\hline & & & \\
\hline \multicolumn{4}{|l|}{ b. Is there evidence of erosion (wind or water)? } \\
\hline \multicolumn{4}{|l|}{ c. Is there evidence of human intrusion onto the site? } \\
\hline \multicolumn{4}{|l|}{ d. Is there evidence of large animal intrusion onto the site? } \\
\hline \multirow{2}{*}{$\begin{array}{l}\text { 3. Site Markers (WSI Training Facility): } \\
\text { a. Have any posts been damaged or their anchoring } \\
\text { weakened? }\end{array}$} & YES & NO & EXPLANATION (required if shaded box is checked) \\
\hline & & & 1 D post down \\
\hline \multicolumn{4}{|l|}{ b. Are all use restriction signs legible? } \\
\hline \multicolumn{4}{|l|}{ c. Are any use restriction signs damaged or missing? } \\
\hline d. How many damaged or missing signs need to be replaced? & \multicolumn{2}{|r|}{0} & \\
\hline e. Are any use restriction signs down? & & & docer \\
\hline f. How many down signs need to be re-hung? & \multicolumn{2}{|c|}{2} & \\
\hline \multirow{2}{*}{$\begin{array}{l}\text { 4. Waste Unit Cover (WSI Training Facility): } \\
\text { a. Is there evidence of settling? }\end{array}$} & YES & NO & EXPLANATION (required if shaded box is checked) \\
\hline & & & \\
\hline b. Is there evidence of erosion (wind or water)? & & $\checkmark$ & \\
\hline c. Is there evidence of human intrusion onto the site? & & 2 & \\
\hline d. Is there evidence of large animal intrusion onto the site? & & & \\
\hline \multicolumn{4}{|l|}{$\begin{array}{l}\text { - Photographs should be taken to document maintenance/repair need } \\
\text { intended for use in the annual post-closure report. } \\
\text { - Anomalous features or new features (such as changes in adjacent a } \\
\text { - Other photographs are optional. } \\
\text { - A photograph log entry will be made for each photograph taken. }\end{array}$} \\
\hline \multirow{2}{*}{$\begin{array}{l}\text { 5. Photograph Documentation: } \\
\text { a. Have photographs been taken of the site? }\end{array}$} & YES & NO & EXPLANATION \\
\hline & & & \\
\hline If yes, how many photos were taken? & \multicolumn{2}{|c|}{5} & \\
\hline If yes, has a photographic log been prepared? & & & 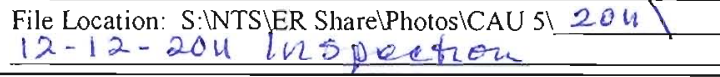 \\
\hline E. FIELD CONCLUSIONS & YES & NO & EXPLANATION (required if shaded box is checked) \\
\hline 1. Are more frequent inspections required? & & & \\
\hline 2. Are existing maintenance/repair actions satisfactory? & & & \\
\hline 3. Are maintenance/repair actions necessary? & & & $\begin{array}{r}\text { Repair } 2 \text { Tosts, Rehang } \\
3 \text { sishs }\end{array}$ \\
\hline 4. Is there an imminent hazard to the integrity of the landfill cover? & & & \\
\hline
\end{tabular}




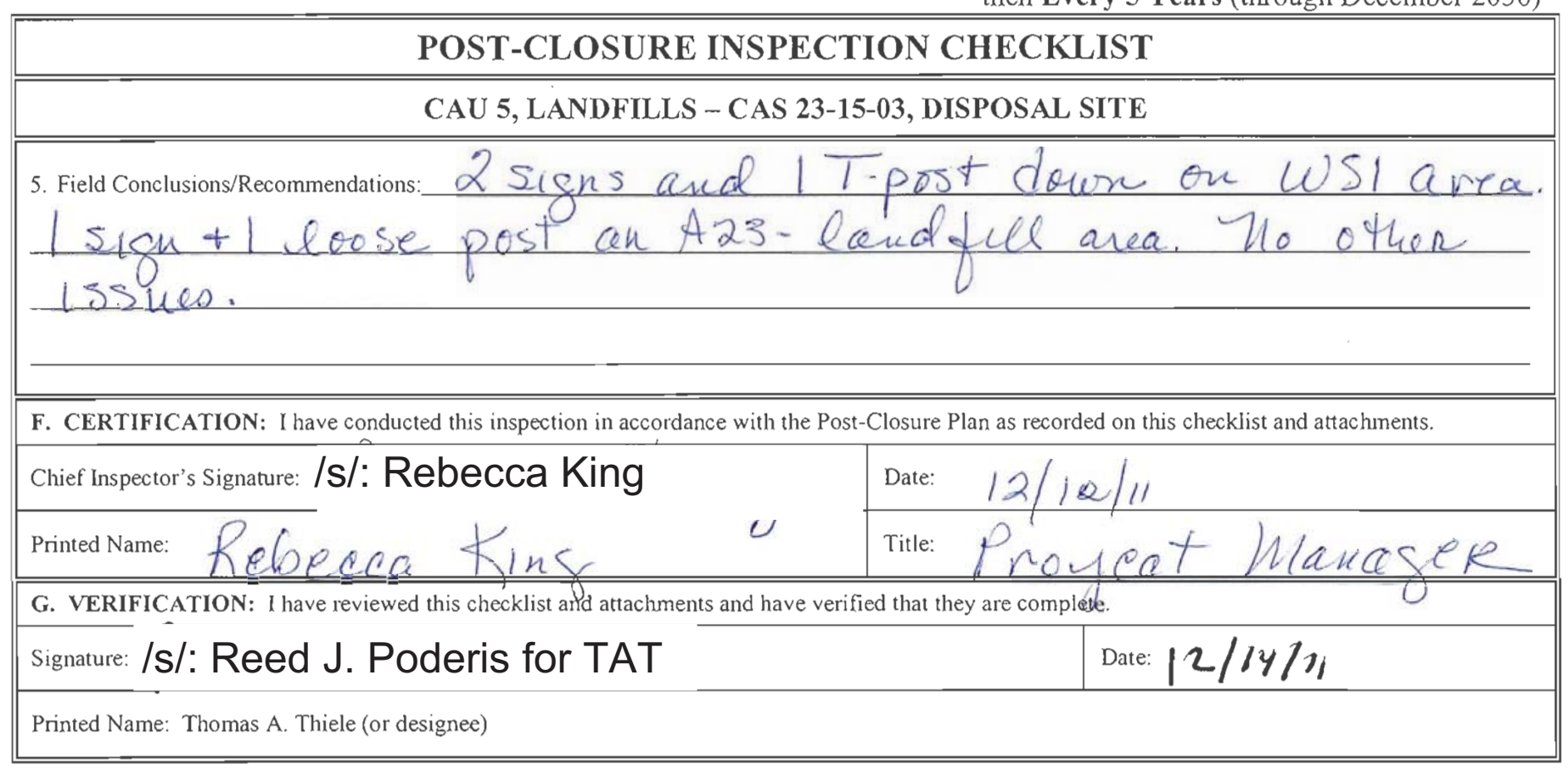


THIS PAGE INTENTIONALLY LEFT BLANK 
CAU 113: AREA 25 R-MAD FACILITY 
THIS PAGE INTENTIONALLY LEFT BLANK 


\section{POST-CLOSURE INSPECTION CHECKILIST}

\section{CAU 113, AREA 25 R-MAD FACILITY - CAS 25-41-01, R-MAD FACILITY}

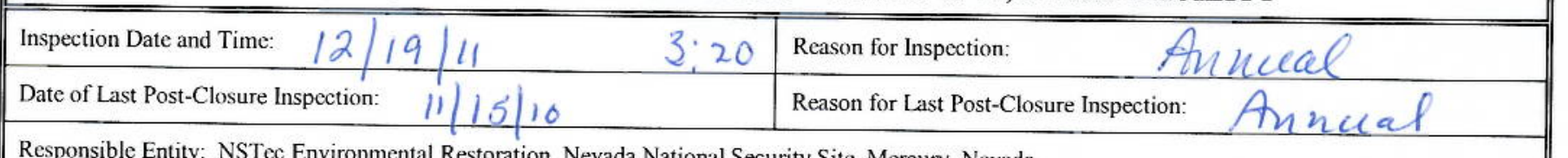

Responsible Entity: NSTec Environmental Restoration, Nevada National Security Site, Mercury, Nevada

Responsible Facility Owner: Thomas A. Thiele, Project Manager, Industrial Sites, Environmental Restoration Project

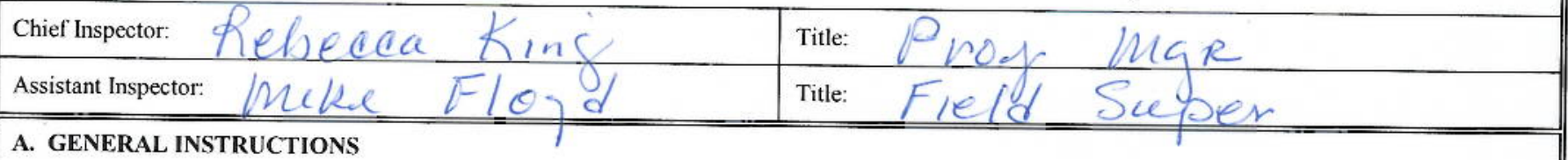

A. GENERAL INSTRUCTIONS

- Complete all checklist items.

- If a SHADED BOX is checked, provide detailed information and/or appropriate references to other documents that have the information.

- All documentation must be legible and clear.

\begin{tabular}{||l|l|l|l||}
\hline \hline B. PREPARATION (To be completed prior to site visit) & YES & NO & EXPLANATION (required if shaded box is checked) \\
\hline 1. Has the Post-Closure Plan been reviewed? & & & \\
2. Have the previous inspection reports been reviewed? & & & \\
3. Were anomalies or trends detected on previous inspections? & & & \\
4. Were maintenance or repair activities performed since the last \\
inspection?
\end{tabular}

\section{SITE INSPECTION PREPARATION}

Assemble the following, as needed, to conduct inspections:

- Radio, pager, etc.

- Previous letter report, inspection checklists, repair records, and as-built plans

- Camera, digital storage drive, extra batteries, and other miscellaneous support equipment

D. SITE INSPECTION

- The site inspection is a walking inspection of the perimeter of the use-restricted area and sufficient transects of the use-restricted area to be able to inspect the entire surface and all features specifically described in this checklist. The inspection does not include the outer $R$-MAD Facility fence or any areas within the R-MAD Facility fence that are outside the use-restricted area. The checklist should be completed during the site inspection.

- If a shaded box is checked, add detailed comments to document the results of the site inspection. Information provided should be of sufficient detail to enable reconstruction of observations regarding field conditions. The completed checklist is part of the field record of the inspection.

- Field notes taken to assist in completion of this checklist will become part of the inspection record. No form is specified for field notes, and additional field notes are not required if the checklist and associated attachments adequately describe site conditions.

1. Site Markers:

a. Have any posts been damaged or their anchoring weakened?

b. Are all use restriction signs legible?

c. Are any of the 10 use restriction signs damaged or missing?

d. How many damaged or missing signs need to be replaced?

e. Are any use restriction signs down?

f. How many down signs need to be re-hung?

g. Do any Underground Radioactive Material Area signs need to be replaced or re-hung?

2. Use-Restricted Area:

a. Is there evidence of human intrusion onto the site?

\begin{tabular}{|c|l|l||}
\hline YES & NO & EXPLANATION (required if shaded box is checked) \\
\hline & & \\
\hline & & \\
\hline & & \\
\hline & $/$ & \\
\hline & & \\
\hline & & \\
\hline YES & NO & EXPLANATION (required if shaded box is checked) \\
\hline & & \\
\hline
\end{tabular}

Page 1 of 2 


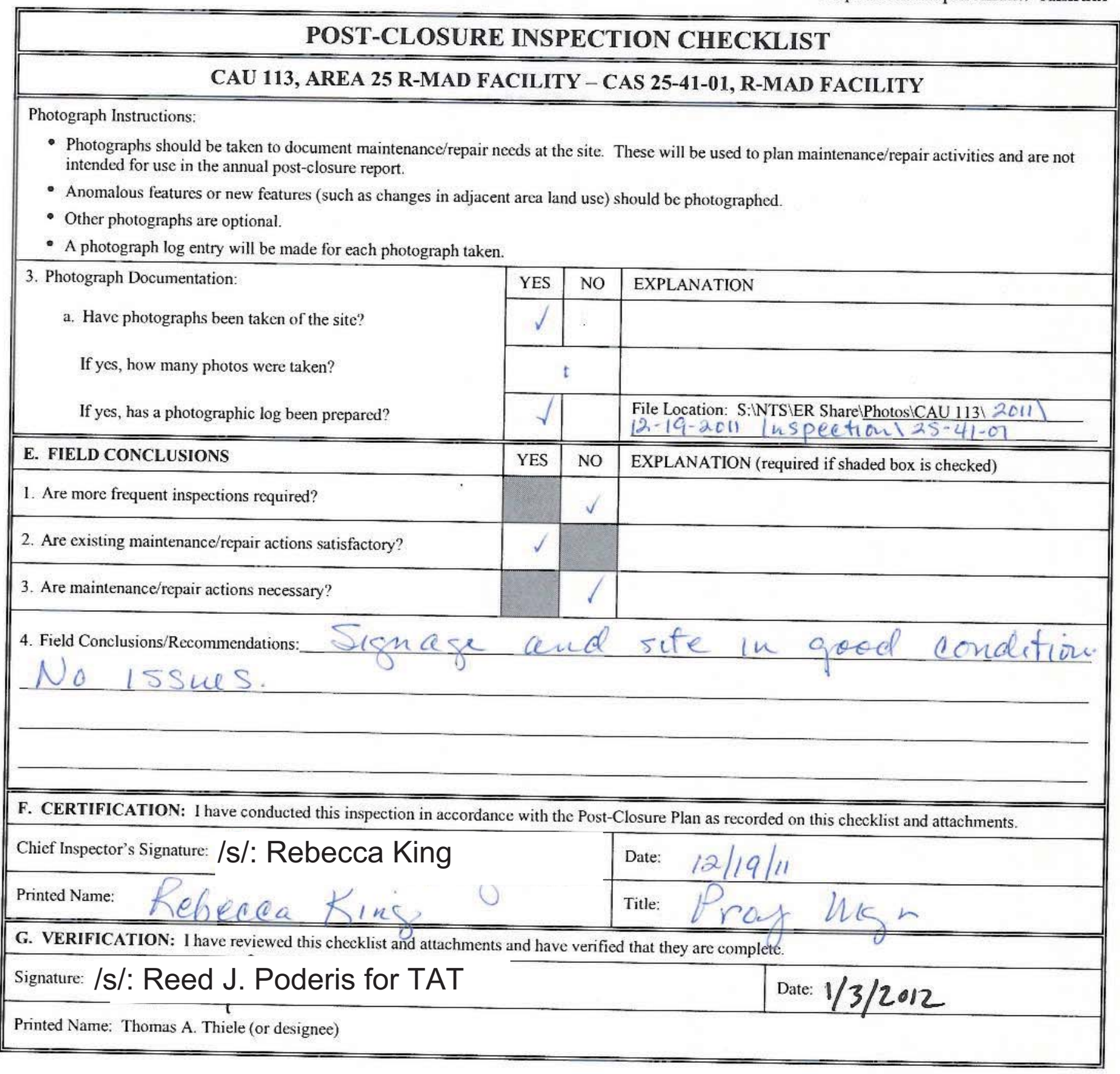


CAU 115: AREA 25 TEST CELL A FACILITY 
THIS PAGE INTENTIONALLY LEFT BLANK 


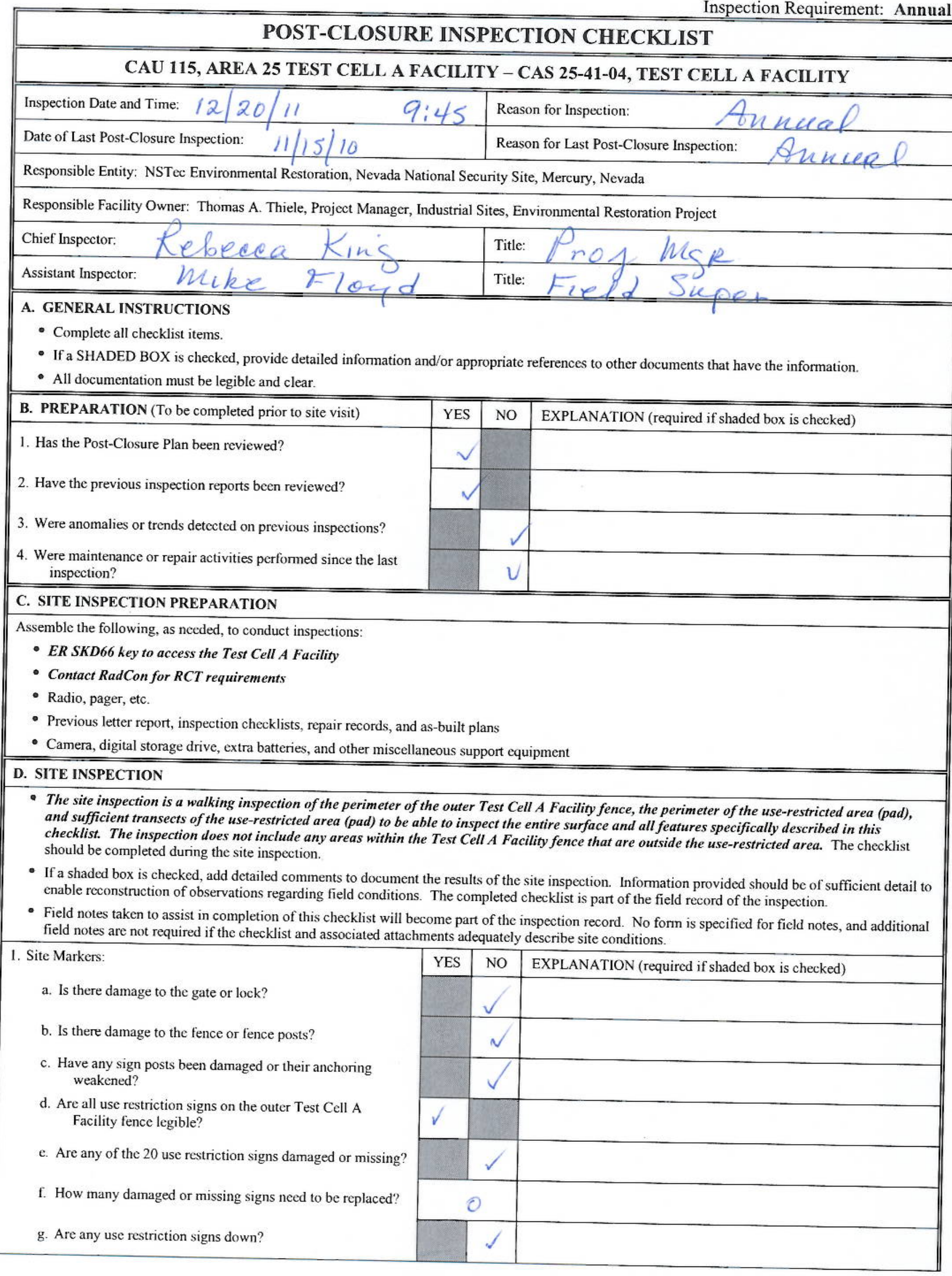


POST-CLOSURE INSPECTION CHECKLIST

CAU 115, AREA 25 TEST CELL A FACILITY - CAS 25-41-04, TEST CELL A FACILITY

h. How many down signs need to be re-hung?

i. Do any Radioactive Material Area signs on the outer Test Cell A Facility fence need to be replaced or re-hung?

j. Do any Underground Radioactive Material Area signs around the pad need to be replaced or re-hung?

2. Use-Restricted Area:

a. Is there evidence of human intrusion onto the site?

\begin{tabular}{|c|c|l||}
\hline \multicolumn{2}{|c|}{0} & \\
\hline & $\checkmark$ & \\
\hline & $\sqrt{ }$ & \\
\hline YES & NO & EXPLANATION (required if shaded box is checked) \\
\hline & $\sqrt{ }$ & \\
\hline
\end{tabular}

Photograph Instructions:

- Photographs should be taken to document maintenance/repair needs at the site. These will be used to plan maintenance/repair activities and are not intended for use in the annual post-closure report.

- Anomalous features or new features (such as changes in adjacent area land use) should be photographed.

- Other photographs are optional.

- A photograph log entry will be made for each photograph taken.

3. Photograph Documentation:

a. Have photographs been taken of the site?

If yes, how many photos were taken?

If yes, has a photographic log been prepared?

\section{E. FIELD CONCLUSIONS}

1. Are more frequent inspections required?

2. Are existing maintenance/repair actions satisfactory?

3. Are maintenance/repair actions necessary? 4. Field Conclusions/Recommendations: sis nace, fenderis

File Location: S: 12 TS $\backslash$ ER Share $P$ Photos $\backslash$ CAU 115 $\backslash 20 \mathrm{~W} \backslash$ 12-20-20 li luspectión

\begin{tabular}{llll}
\hline YES & NO & EXPLANATION (required if shaded box is checked)
\end{tabular}

V

$\checkmark$

\section{$y$ ?}


CAU 116: AREA 25 TEST CELL C FACILITY 
THIS PAGE INTENTIONALLY LEFT BLANK 
POST-CLOSURE INSPECTION CHECKLIST

CAU 116, AREA 25 TEST CELL C FACILITY - CAS 25-41-05, TEST CELL C FACILITY

\begin{tabular}{|ll|l|l|l}
\hline Inspection Date and Time: $12 / 20 / 11$ & $9 ; 15$ & Reason for Inspection: \\
\hline Date of Last Post-Closure Inspection: $N A$ & Reason for Last Post-Closure Inspection:
\end{tabular}

Responsible Entity: NSTec Environmental Restoration, Nevada National Security Site, Mercury, Nevada

Responsible Facility Owner: Thomas A. Thiele, Project Manager, Industrial Sites, Environmental Restoration Project

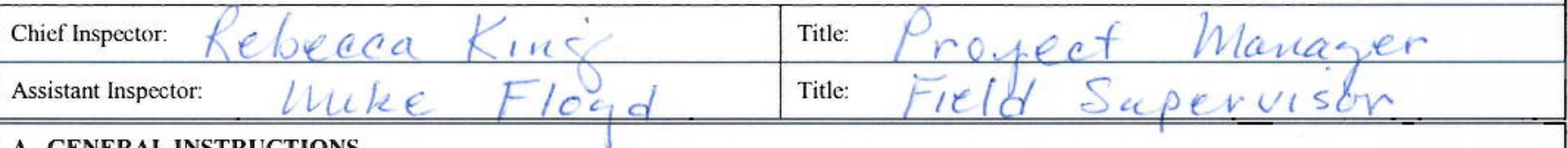

\section{A. GENERAL INSTRUCTIONS}

- Complete all checklist items.

- If a SHADED BOX is checked, provide detailed information and/or appropriate references to other documents that have the information.

- All documentation must be legible and clear.

\begin{tabular}{|l|l|l|l}
\hline B. PREPARATION (To be completed prior to site visit) & YES & NO & EXPLANATION (required if shaded box is checked)
\end{tabular}

1. Has the Post-Closure Plan been reviewed?

2. Have the previous inspection reports been reviewed?

3. Were anomalies or trends detected on previous inspections?

4. Were maintenance or repair activities performed since the last inspection?

\section{SITE INSPECTION PREPARATION}

Assemble the following, as needed, to conduct inspections:

- ER SKD66 key to access the Test Cell C Facility

- Contact RadCon for RCT requirements

- Radio, pager, etc.

- Previous letter report, inspection checklists, repair records, and as-built plans

- Camera, digital storage drive, extra batteries, and other miscellaneous support equipment

\section{SITE INSPECTION}

- The site inspection is a walking inspection of the perimeter of the use-restricted area and sufficient transects of the use-restricted area to be able to inspect the entire surface and all features specifically described in this checklist. The inspection does not include the outer Test Cell C Facility fence or any areas within the Test Cell C Facility fence that are outside the use-restricted area. The checklist should be completed during the site inspection.

- If a shaded box is checked, add detailed comments to document the results of the site inspection. Information provided should be of sufficient detail to enable reconstruction of observations regarding field conditions. The completed checklist is part of the field record of the inspection.

- Field notes taken to assist in completion of this checklist will become part of the inspection record. No form is specified for field notes, and additional field notes are not required if the checklist and associated attachments adequately describe site conditions.

1. Site Markers:

a. Is there damage to the gate or lock?

b. Is there damage to the fence or fence posts?

c. Have any sign posts been damaged or their anchoring weakened?

d. Are all use restriction signs legible?

e. Are any use restriction signs damaged or missing?

f. How many damaged or missing signs need to be replaced?

g. Are any use restriction signs down?

\begin{tabular}{|l|l|l|}
\hline YES & NO & EXPLANATION (required if shaded box is checked) \\
\hline & & \\
\hline & & \\
\hline & & \\
\hline & & \\
\hline & & \\
\hline & & \\
\hline & & \\
\hline
\end{tabular}


POST-CLOSURE INSPECTION CHECKLIST

CAU 116, AREA 25 TEST CELL C FACILITY - CAS 25-41-05, TEST CELL C FACILITY

h. How many down signs need to be re-hung?

i. Do any Underground Radioactive Material Area signs need to be replaced or re-hung?

2. Use-Restricted Area:

a. Is there evidence of human intrusion onto the site?

Photograph Instructions:

- Photographs should be taken to document maintenance/repair needs at the site. These will be used to plan maintenance/repair activitics and are not intended for use in the annual post-closure report.

- Anomalous features or new features (such as changes in adjacent area land use) should be photographed.

- Other photographs are optional.

- A photograph log entry will be made for each photograph taken.

3. Photograph Documentation:

a. Have photographs been taken of the site?

If yes, how many photos were taken?

If yes, has a photographic log been prepared?

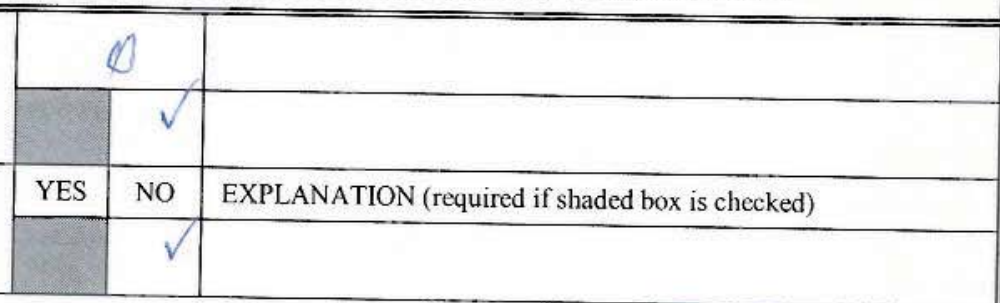

E. FIELD CONCLUSIONS

1. Are more frequent inspections required?

2. Are existing maintenance/repair actions satisfactory?

3. Are maintenance/repair actions necessary?

4. Field Conclusions/Recommendations: Sishage
Ho losucs at othis site

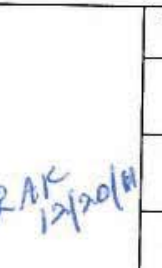

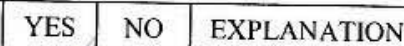

F. CERTIFICATION: I have conducted this inspection in accordance with the Post-Closure Plan as recorded on this checklist and attachments.

Chief Inspector's Signature: /s/: Rebecca King

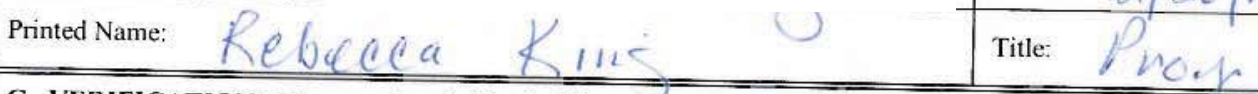

G. VERIFICATION: I have reviewed this checklist and attachments and have verified that they are complete.

Signature: /s/: Reed J. Poderis for TAT

Date: $1 / 3 / 2$ or 2

Printed Name: Thomas A. Thiele (or designee) 
CAU 118: AREA 27 SUPER KUKLA FACILITY 
THIS PAGE INTENTIONALLY LEFT BLANK 


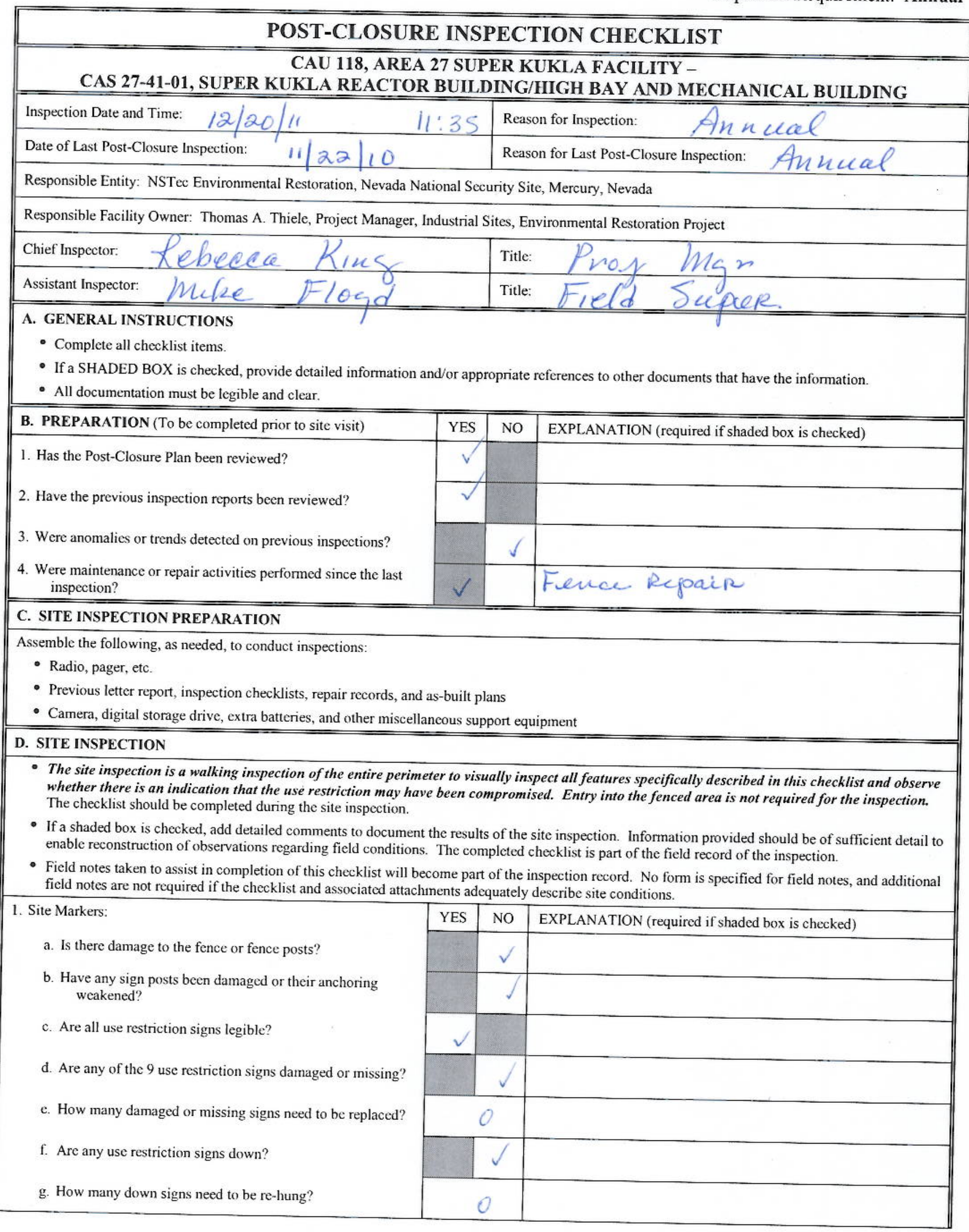




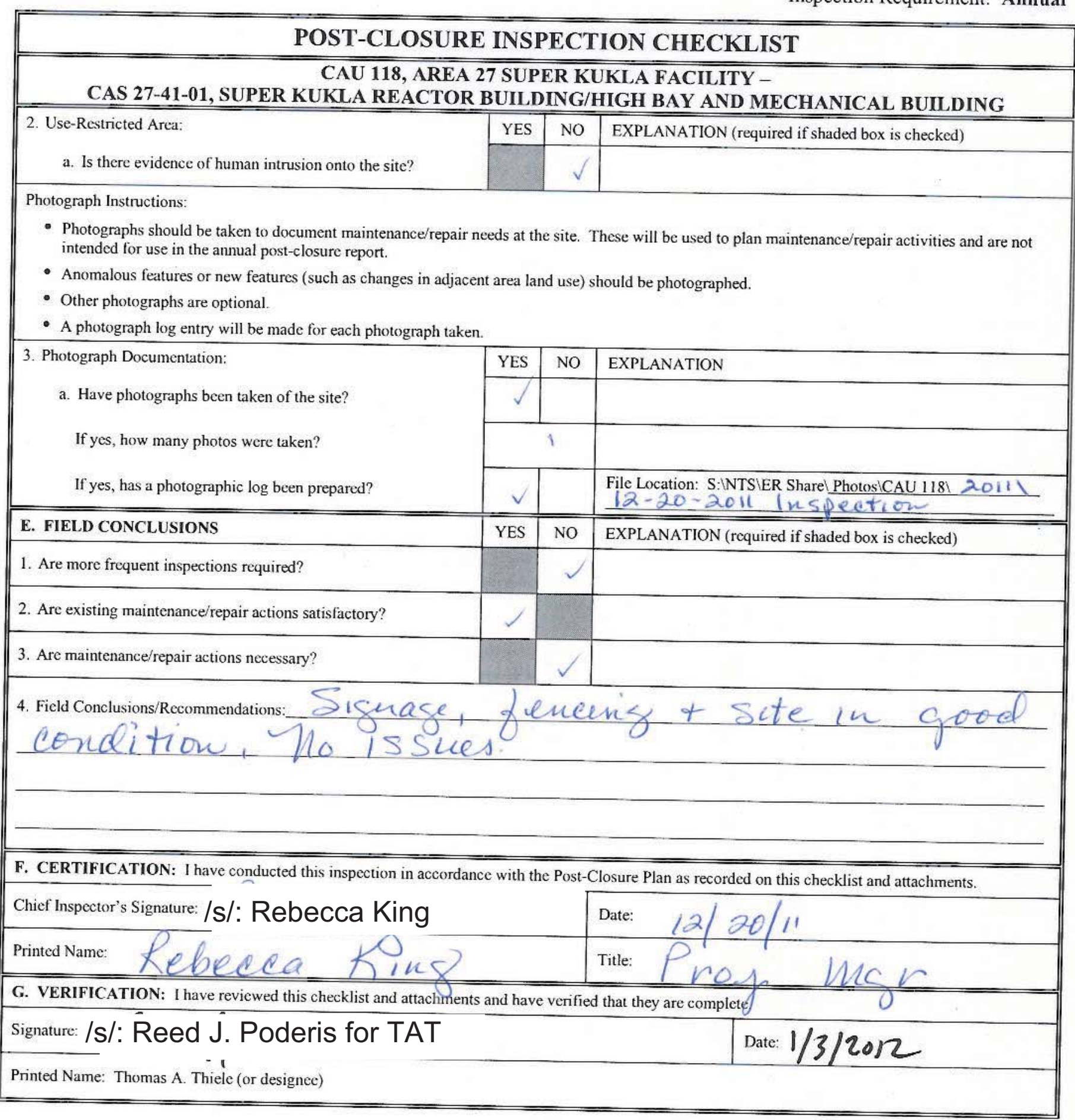


CAU 127: AREAS 25 AND 26 STORAGE TANKS 
THIS PAGE INTENTIONALLY LEFT BLANK 


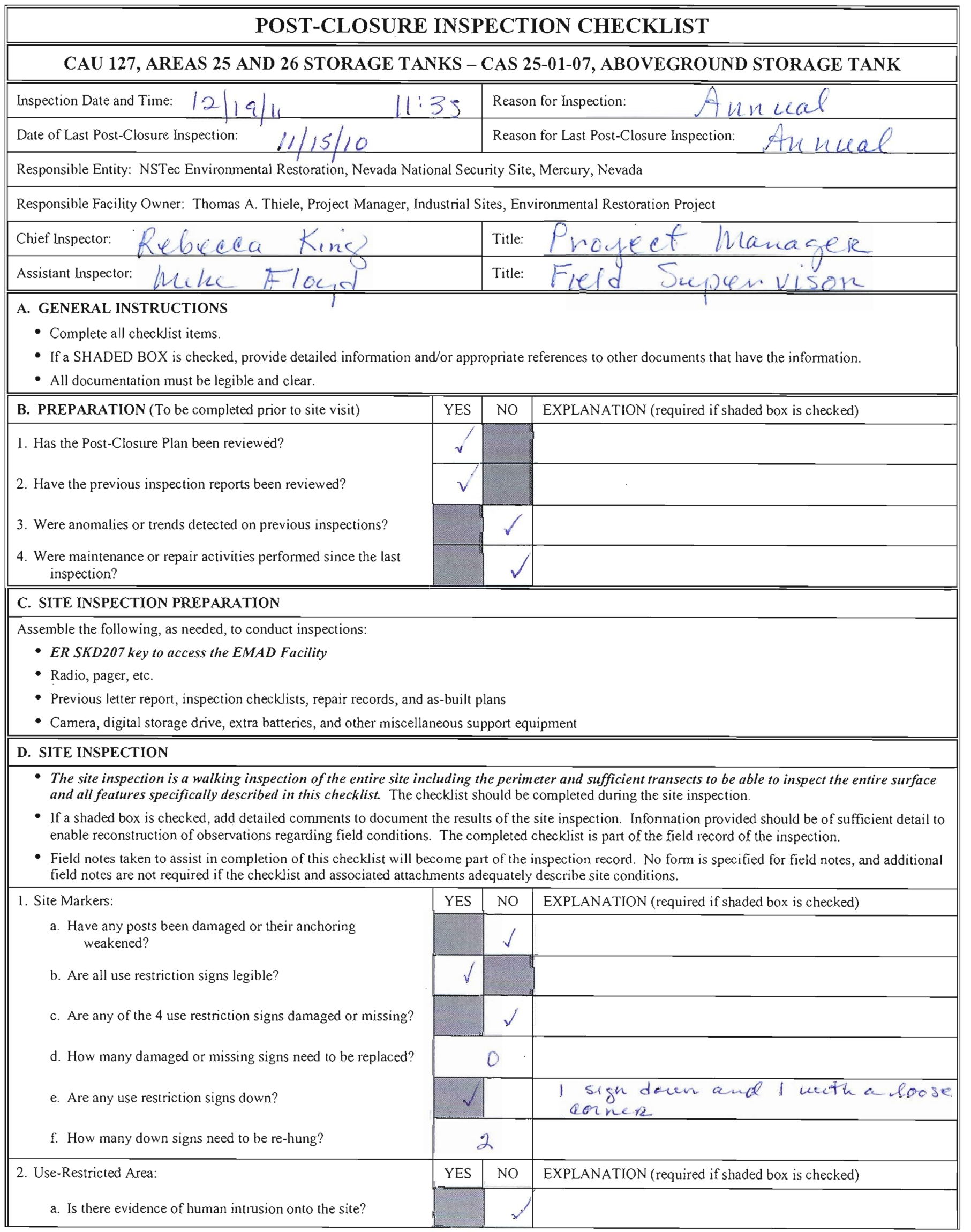




\section{POST-CLOSURE INSPECTION CHECKLIST}

\section{CAU 127, AREAS 25 AND 26 STORAGE TANKS - CAS 25-01-07, ABOVEGROUND STORAGE TANK}

Photograph Instructions:

- Photographs should be taken to document maintenance/repair needs at the site. These will be used to plan maintenance/repair activities and are not intended for use in the annual post-closure report.

- Anomalous features or new features (such as changes in adjacent area land use) should be photographed.

- Other photographs are optional

- A photograph log entry will be made for each photograph taken.

3. Photograph Documentation:

a. Have photographs been taken of the site?

If yes, how many photos were taken?

If yes, has a photographic log been prepared?

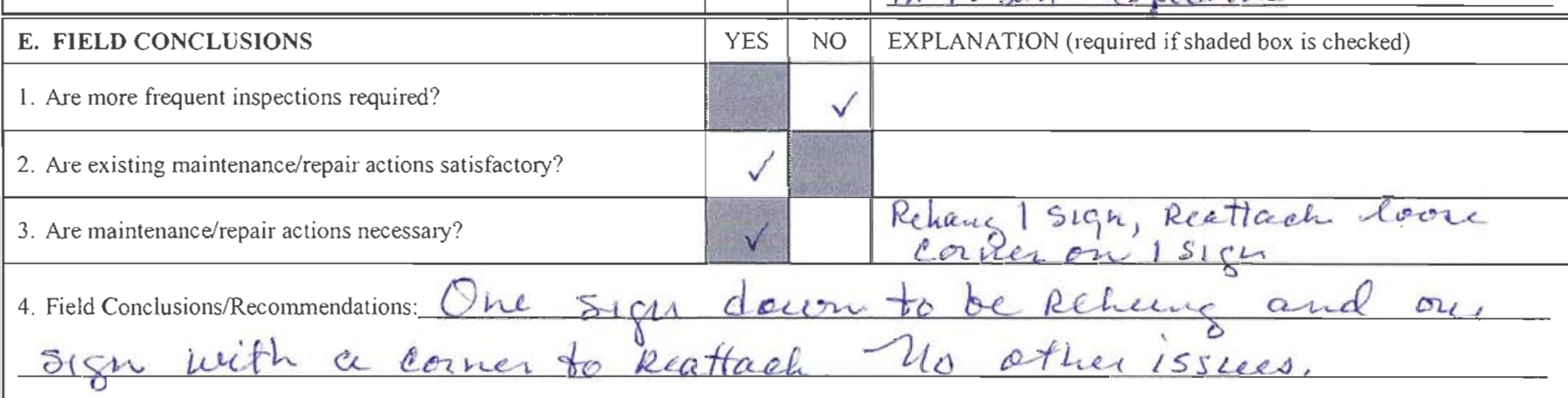

F. CERTIFICATION: I have conducted this inspection in accordance with the Post-Closure Plan as recorded on this checklist and attachments

Cliee Inspector's signature: /s/: Rebecca King

Printed Name: Tebeopa Kaks

O

\begin{tabular}{|r|r|r|}
\hline YES & NO \\
\hline & \\
\hline \multicolumn{2}{|r|}{2} & \\
\hline$\checkmark$ & YES & NO \\
\hline$\checkmark$ & \\
$\checkmark$ & \\
\hline
\end{tabular}

EXPLANATION

\begin{tabular}{c|c} 
& \\
\hline & \\
\hline & \\
\hline &
\end{tabular}

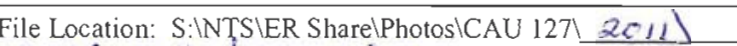
$12-19-201 \mid$ inspection.

G. VERIFICATION: I have reviewed this checklist and attachments and have verified that they are complete. Signature: /s/: Reed J. Poderis for TAT Date: $\quad 1 / 3 / 2012$

Printed Name: Thomas A. Thiele (or designee) 


\section{POST-CLOSURE INSPECTION CHECKLIST}

\section{CAU 127, AREAS 25 AND 26 STORAGE TANKS - CAS 25-02-02, UNDERGROUND STORAGE TANK}

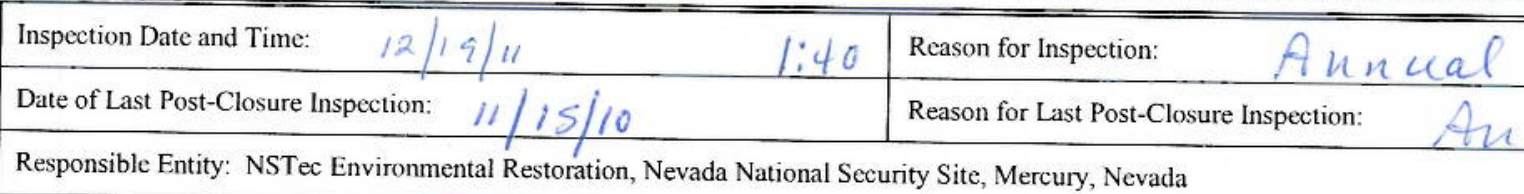

Responsible Facility Owner: Thomas A. Thiele, Project Manager, Industrial Sites, Environmental Restoration Project

\begin{tabular}{|c|c|c|}
\hline Chief Inspector: & Reloreca Kins & Title: Proyeet Mauaser \\
\hline Assistant Inspector: & mike Flocid & Title: Fleld Supervison \\
\hline
\end{tabular}

\section{A. GENERAL INSTRUCTIONS}

- Complete all checklist items.

- If a SHADED BOX is checked, provide detailed information and/or appropriate references to other documents that have the information.

- All documentation must be legible and clear.

\begin{tabular}{||l|l|l|l||}
\hline B. PREPARATION (To be completed prior to site visit) & YES & NO & EXPLANATION (required if shaded box is checked) \\
\hline $\begin{array}{l}\text { 1. Has the Post-Closure Plan been reviewed? } \\
\text { 2. Have the previous inspection reports been reviewed? }\end{array}$ & & & \\
\cline { 2 - 5 } $\begin{array}{l}\text { 3. Were anomalies or trends detected on previous inspections? } \\
\text { 4. Were maintenance or repair activities performed since the last } \\
\text { inspection? }\end{array}$ & & $\checkmark$ & \\
\hline \hline
\end{tabular}

\section{SITE INSPECTION PREPARATION}

Assemble the following, as needed, to conduct inspections:

- Radio, pager, etc.

- Previous letter report, inspection checklists, repair records, and as-built plans

- Camera, digital storage drive, extra batteries, and other miscellaneous support equipment

\section{SITE INSPECTION}

- The site inspection is a walking inspection of the entire site including the perimeter and sufficient transects to be able to inspect the entire surface and all features specifically described in this checklist. The checklist should be completed during the site inspection.

- If a shaded box is checked, add detailed comments to document the results of the site inspection. Information provided should be of sufficient detail to enable reconstruction of observations regarding field conditions. The completed checklist is part of the field record of the inspection.

- Field notes taken to assist in completion of this checklist will become part of the inspection record. No form is specified for field notes, and additional field notes are not required if the checklist and associated attachments adequately describe site conditions.

\section{Site Markers:}

a. Have any posts been damaged or their anchoring weakened?

b. Are all use restriction signs legible?

c. Are any of the 4 use restriction signs damaged or missing?

d. How many damaged or missing signs need to be replaced?

e. Are any use restriction signs down?

f. How many down signs need to be re-hung?

g. Do any Underground Radioactive Material Area signs need to be replaced or re-hung?

2. Use-Restricted Area:

a. Is there evidence of human intrusion onto the site?

\begin{tabular}{|r|l|l||}
\hline YES & NO & EXPLANATION (required if shaded box is checked) \\
\hline & & \\
\hline$\checkmark$ & & \\
\hline & & \\
\hline & & \\
\hline & & \\
\hline & & \\
\hline & $\checkmark$ & \\
\hline YES & NO & EXPLANATION (required if shaded box is checked) \\
\hline & & \\
\hline
\end{tabular}




\section{POST-CLOSURE INSPECTION CHECKLIST}

\section{CAU 127, AREAS 25 AND 26 STORAGE TANKS - CAS 25-02-02, UNDERGROUND STORAGE TANK}

Photograph Instructions:

- Photographs should be taken to document maintenance/repair needs at the site. These will be used to plan maintenance/repair activities and are not intended for use in the annual post-closure report.

- Anomalous features or new features (such as changes in adjacent area land use) should be photographed.

- Other photographs are optional.

- A photograph log entry will be made for each photograph taken.

3. Photograph Documentation:

a. Have photographs been taken of the site?

If yes, how many photos were taken?

If yes, has a photographic log been prepared?

\section{E. FIELD CONCLUSIONS}

1. Are more frequent inspections required?

2. Are existing maintenance/repair actions satisfactory?

3. Are maintenance/repair actions necessary?

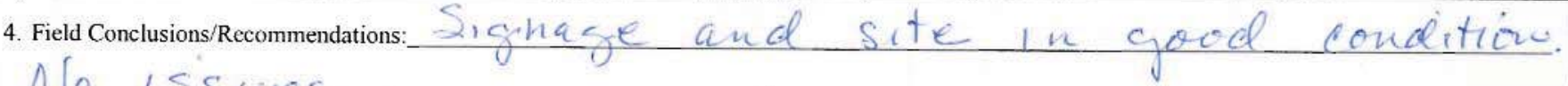

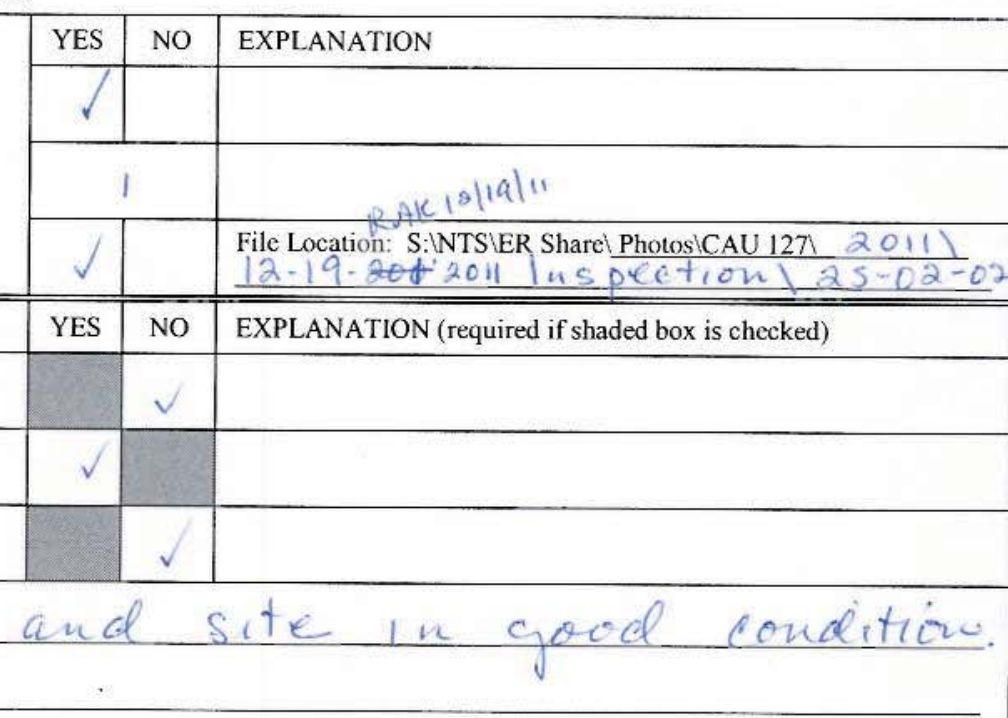

ha 1 s seces

F. CERTIFICATION: I have conducted this inspection in accordance with the Post-Closure Plan as recorded on this checklist and attachments.

Chief Inspector's Signature: /s/: Rebecca King

Printed Name:
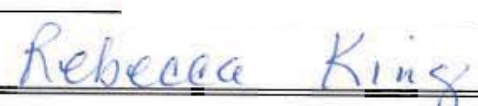

Date: $12 / 19 / 11$

G. VERIFICATION: I have reviewed this checklist and attachments and have verified that they are complete.

\begin{tabular}{|l|l}
\hline Signature: /s/: Reed J. Poderis for TAT & Date: $1 / 3 / 2012$
\end{tabular}

Printed Name: Thomas A. Thicle (or designee) 
CAU 137: WASTE DISPOSAL SITES 
THIS PAGE INTENTIONALLY LEFT BLANK 


\section{POST-CLOSURE INSPECTION CHECKLIST}

\section{CAU 137, WASTE DISPOSAL SITES - CAS 01-08-01, WASTE DISPOSAL SITE}

\begin{tabular}{|c|c|}
\hline Inspection Date and Time: $1 / 18 / \mathrm{l} \quad 2: 25 \mathrm{pm}$ & Reason for Inspection: \\
\hline Date of Last Post-Closure Inspection: $\quad 1 / / 9 / 10$ & Reason for Last Post-Closure Inspection: \\
\hline \multicolumn{2}{|c|}{ Responsible Entity: NSTec Environmental Restoration, Nevada National Security Site, Mercury, Nevada } \\
\hline \multicolumn{2}{|c|}{ Responsible Facility Owner: Thomas A. Thiele, Project Manager, Industrial Sites, Environmental Restoration Project } \\
\hline Chief Inspector: & aser \\
\hline Assistant Inspector: Were Fl $\left.(G)_{0}\right)^{\circ}$ & Title: Fiejd \\
\hline
\end{tabular}

\section{A. GENERAL INSTRUCTIONS}

- Complete all checklist items.

- If a SHADED BOX is checked, provide detailed information and/or appropriate references to other documents that have the information.

- All documentation must be legible and clear.

\begin{tabular}{|l|l|l|l}
\hline B. PREPARATION (To be completed prior to site visit) & YES & NO & EXPLANATION (required if shaded box is checked)
\end{tabular}

1. Has the Post-Closure Plan been reviewed?

2. Have the previous inspection reports been reviewed?

3. Were anomalies or trends detected on previous inspections?

4. Were maintenance or repair activities performed since the last inspection?

\section{SITE INSPECTION PREPARATION}

Assemble the following, as needed, to conduct inspections:

- Radio, pager, etc.

- Previous letter report, inspection checklists, repair records, and as-built plans

- Camera, digital storage drive, extra batteries, and other miscellaneous support equipment

\section{SITE INSPECTION}

- The site inspection is a walking inspection of the entire perimeter to visually inspect all features specifically described in this checklist and observe whether there is an indication that the use restriction may have been compromised. Entry into the fenced area is not required for the inspection.

The checklist should be completed during the site inspection.

- If a shaded box is checked, add detailed comments to document the results of the site inspection. Information provided should be of sufficient detail to enable reconstruction of observations regarding field conditions. The completed checklist is part of the field record of the inspection.

- Field notes taken to assist in completion of this checklist will become part of the inspection record. No form is specified for field notes, and additional field notes are not required if the checklist and associated attachments adequately describe site conditions.

1. Site Markers:

a. Is there damage to the fence or fence posts?

b. Have any posts been damaged or their anchoring weakened?

c. Are all use restriction signs legible?

d. Are any of the 10 use restriction signs damaged or missing?

e. How many damaged or missing signs need to be replaced?

f. Are any use restriction signs down?

g. How many down signs need to be re-hung?

\section{Use-Restricted Area:}

a. Is there evidence of human intrusion onto the site?

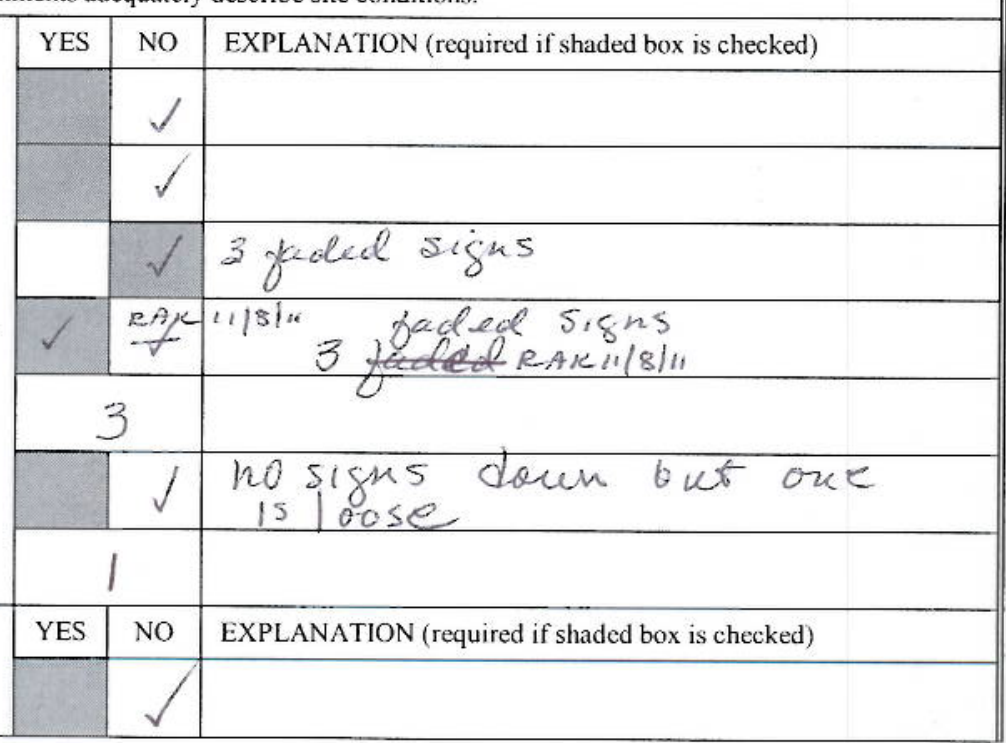




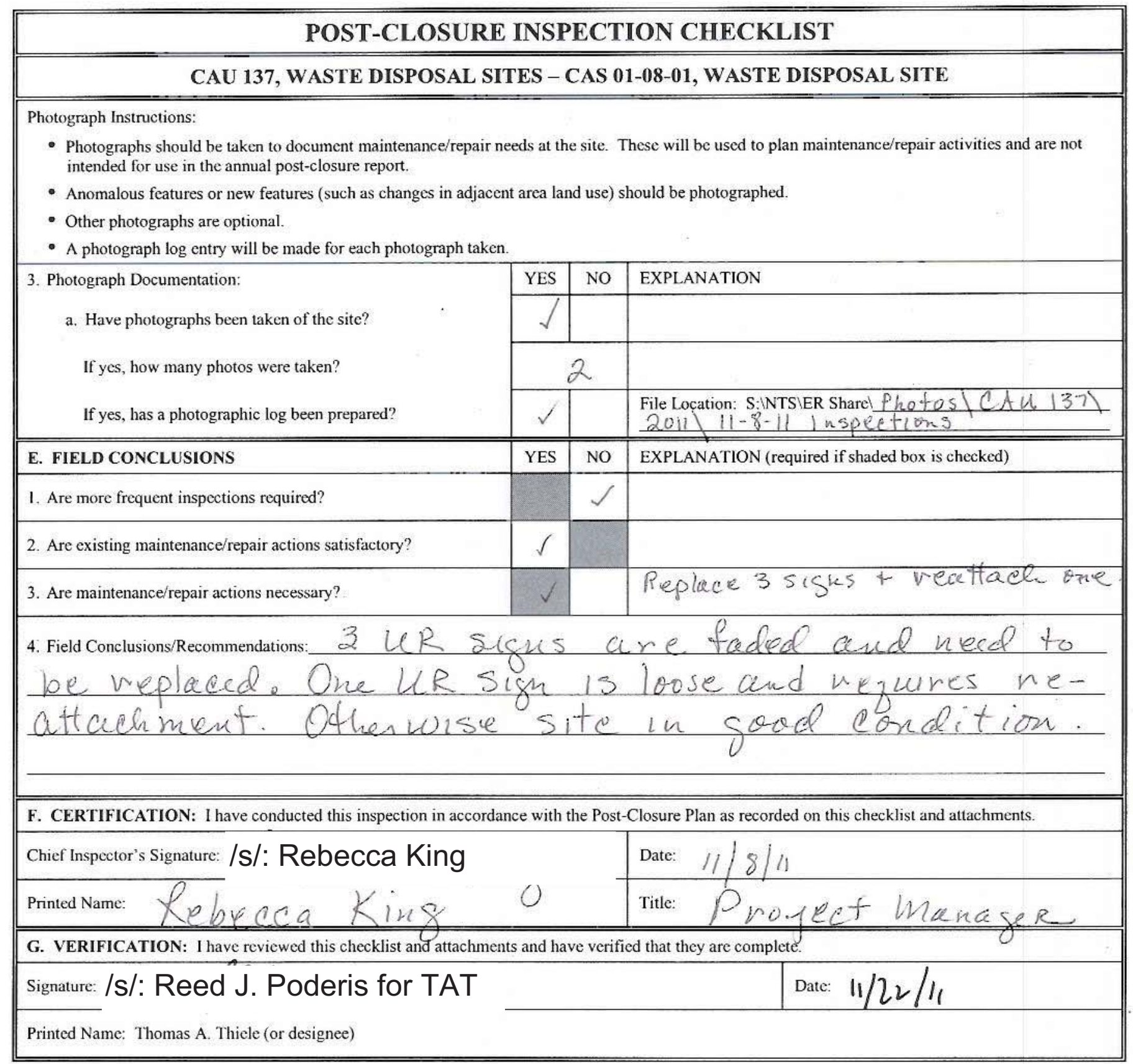




\section{POST-CLOSURE INSPECTION CHECKLIST}

\section{CAU 137, WASTE DISPOSAL SITES - CAS 07-23-02, RADIOACTIVE WASTE DISPOSAL SITE}

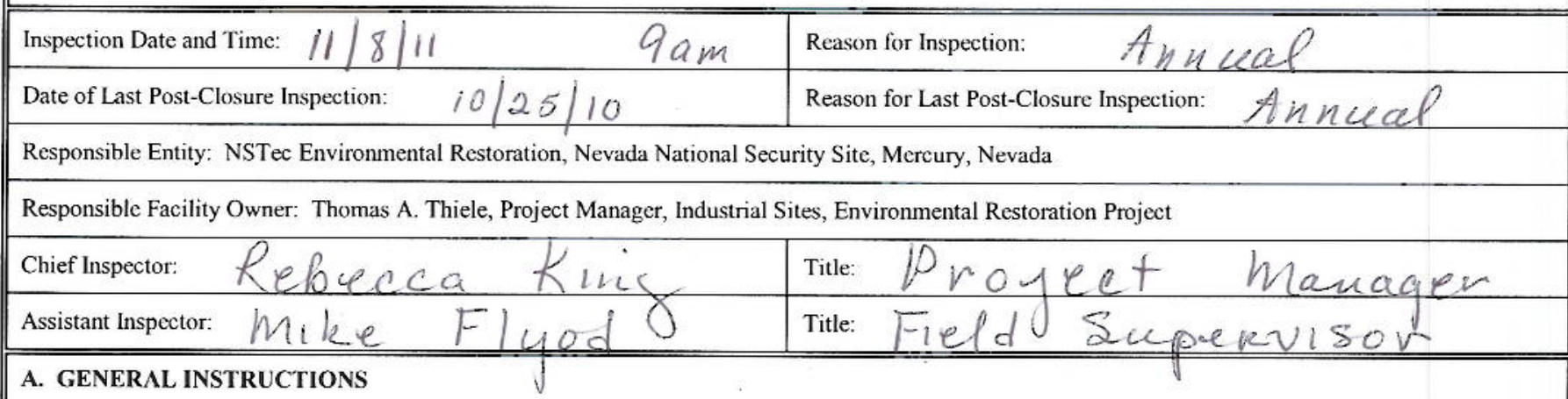

- Complete all checklist items.

- If a SHADED BOX is checked, provide detailed information and/or appropriate references to other documents that have the information.

- All documentation must be legible and clcar.

\begin{tabular}{|l|l|l|l}
\hline \hline B. PREPARATION (To be completed prior to site visit) & YES & NO & EXPLANATION (required if shaded box is checked) \\
\hline
\end{tabular}

1. Has the Post-Closure Plan been reviewed?

2. Have the previous inspection reports been reviewed?

3. Were anomalies or trends detected on previous inspections?

4. Were maintenance or repair activities performed since the last inspection?

\section{SITE INSPECTION PREPARATION}

Assemble the following, as needed, to conduct inspections:

- Radio, pager, etc.

- Previous letter report, inspection checklists, repair records, and as-built plans

- Camera, digital storage drive, extra batteries, and other miscellaneous support equipment

\section{SITE INSPECTION}

- The site inspection is a walking inspection of the entire perimeter to visually inspect all features specifically described in this checklist and observe whether there is an indication that the use restriction may have been compromised. Entry into the fenced area is not required for the inspection. The checklist should be completed during the site inspection.

- If a shaded box is checked, add detailed comments to document the results of the site inspection. Information provided should be of sufficient detail to enable reconstruction of observations regarding field conditions. The completed checklist is part of the field record of the inspection.

- Field notes taken to assist in completion of this checklist will become part of the inspection record. No form is specified for field notes, and additional field notes are not required if the checklist and associated attachments adequately describe site conditions.

1. Site Markers:

a. Is there damage to the fence or fence posts?

b. Have any posts been damaged or their anchoring weakened?

c. Are all use restriction signs legible?

d. Are any of the 6 use restriction signs damaged or missing?

e. How many damaged or missing signs need to be replaced?

f. Are any use restriction signs down?

g. How many down signs need to be re-hung?

h. Do any Underground Radioactive Material Area signs need to be replaced or re-hung?

\begin{tabular}{|r|r|l||}
\hline YES & NO & EXPLANATION (required if shaded box is checked) \\
\hline & $\checkmark$ & \\
\hline & $\checkmark$ & \\
\hline$\checkmark$ & & \\
\hline & $\checkmark$ & \\
\hline & 0 & \\
\hline & $\checkmark$ & \\
\hline & 0 & \\
\hline & $\checkmark$ & \\
\hline
\end{tabular}


Inspection Requirement: Annual

\section{POST-CLOSURE INSPECTION CHECKLIST}

\section{CAU 137, WASTE DISPOSAL SITES - CAS 07-23-02, RADIOACTIVE WASTE DISPOSAL SITE}

2. Use-Restricted Area:

a. Is there evidence of human intrusion onto the site?

Photograph Instructions:

- Photographs should be taken to document maintenance/repair needs at the site. These will be used to plan maintenance/repair activities and are not intended for use in the annual post-closure report.

- Anomalous features or new features. (such as changes in adjacent area land use) should be photographed.

- Other photographs are optional.

- A photograph log entry will be made for each photograph taken.

3. Photograph Documentation:

a. Have photographs been taken of the site?

If yes, how many photos were taken?

If yes, has a photographic log been prepared?

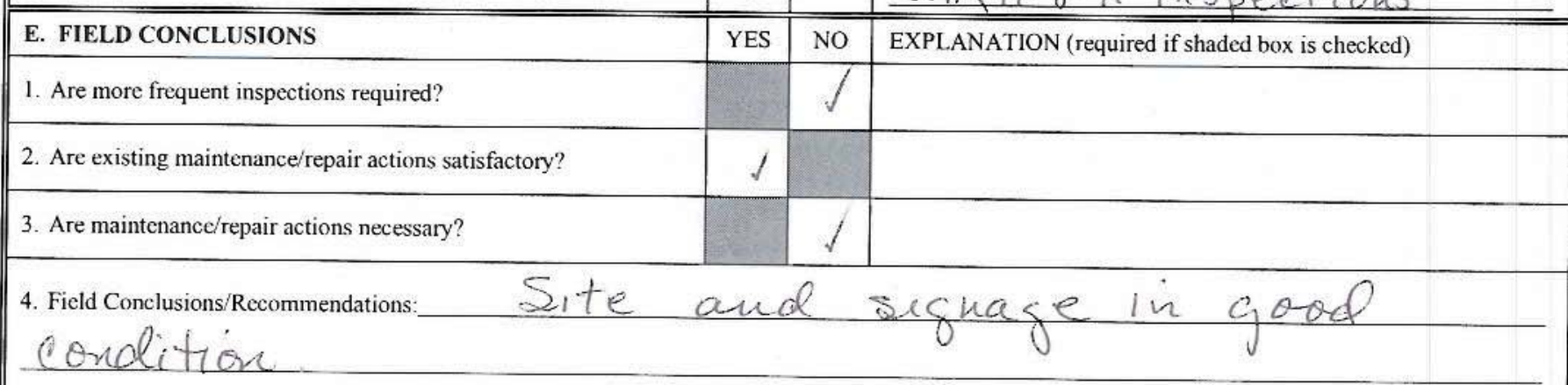

ondition

\begin{tabular}{|r|r|r|}
\hline YES & NO & EXPLANATION (required if shaded box is checked) \\
\hline & & \\
\hline
\end{tabular}
n.

\begin{tabular}{|l|l|l}
\hline YES & NO & EXPLANATION \\
\hline
\end{tabular}




\section{POST-CLOSURE INSPECTION CHECKLIST}

\section{CAU 137, WASTE DISPOSAL SITES -}

CAS 12-08-01, WASTE DISPOSAL SITE, AND CAS 12-23-07, WASTE DISPOSAL SITE

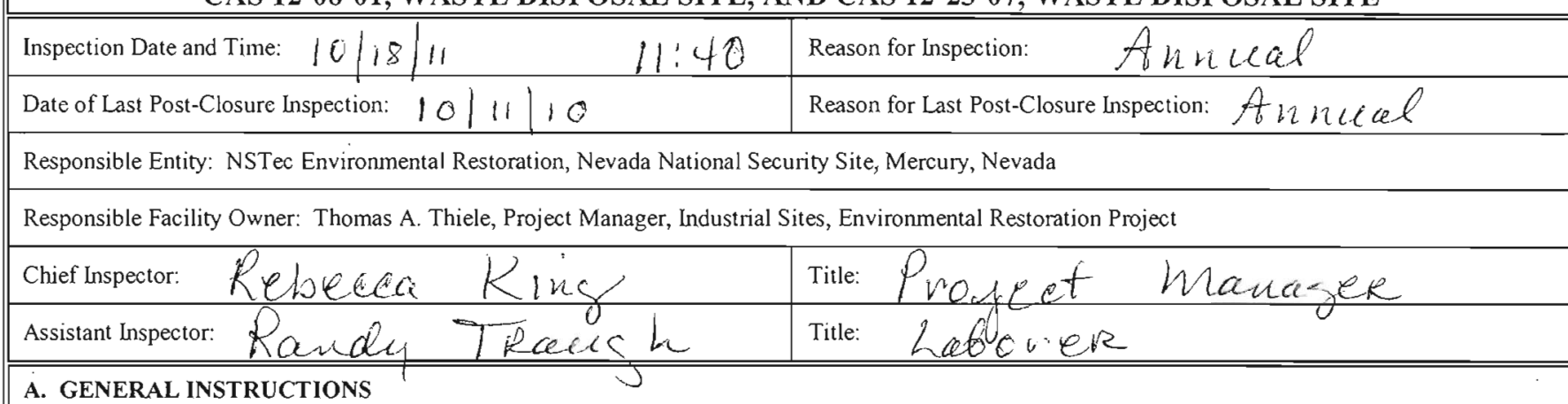

- Complete all checklist iterms.

- If a SHADED BOX is checked, provide detailed information and/or appropriate references to other documents that have the information.

- All documentation must be legible and clear.

\begin{tabular}{|c|c|c|c|}
\hline B. PREPARATION (To be completed prior to site visit) & YES & NO & EXPLANATION (required if shaded box is checked) \\
\hline 3. Were anomalies or trends detected on previous inspections? & & & \\
\hline
\end{tabular}

\section{SITE INSPECTION PREPARATION}

Assemble the following, as needed, to conduct inspections

- Radio, pager, etc.

- Previous letter report, inspection checklists, repair records, and as-built plans

- Camera, digital storage drive, extra batteries, and other miscellaneous support equipment

\section{SITE INSPECTION}

\section{- Check in at the G-Tunnel office prior to the inspection.}

- The site inspection is a walking inspection of the entire perimeter to visually inspect all features specifically described in this checklist and observe whether there is an indication that the use restriction may have been compromised. Entry into the fenced area is not required for the inspection. The checklist should be completed during the site inspection.

- If a shaded box is checked, add detailed comments to document the results of the site inspection. Information provided should be of sufficient detail to enable reconstruction of observations regarding field conditions. The completed checklist is part of the field record of the inspection.

- Field notes taken to assist in completion of this checklist will become part of the inspection record. No form is specified for field notes, and additional field notes are not required if the checklist and associated attachments adequately describe site conditions

1. Site Markers:

a. Is there damage to the fence?

b. Have any posts been damaged or their anchoring weakened?

c. Are all use restriction signs legible?

d. Are any of the 8 use restriction signs damaged or missing?

e. How many damaged or missing signs need to be replaced?

f. Are any use restriction signs down?

g. How many down signs need to be re-hung?

\begin{tabular}{|r|r|l||}
\hline YES & NO & EXPLANATION (required if shaded box is checked) \\
\hline & $\sqrt{ }$ & \\
\hline$\sqrt{ }$ & & \\
\hline & $\sqrt{ }$ & \\
\hline & 0 & \\
\hline & $\sqrt{ }$ & \\
\hline &
\end{tabular}




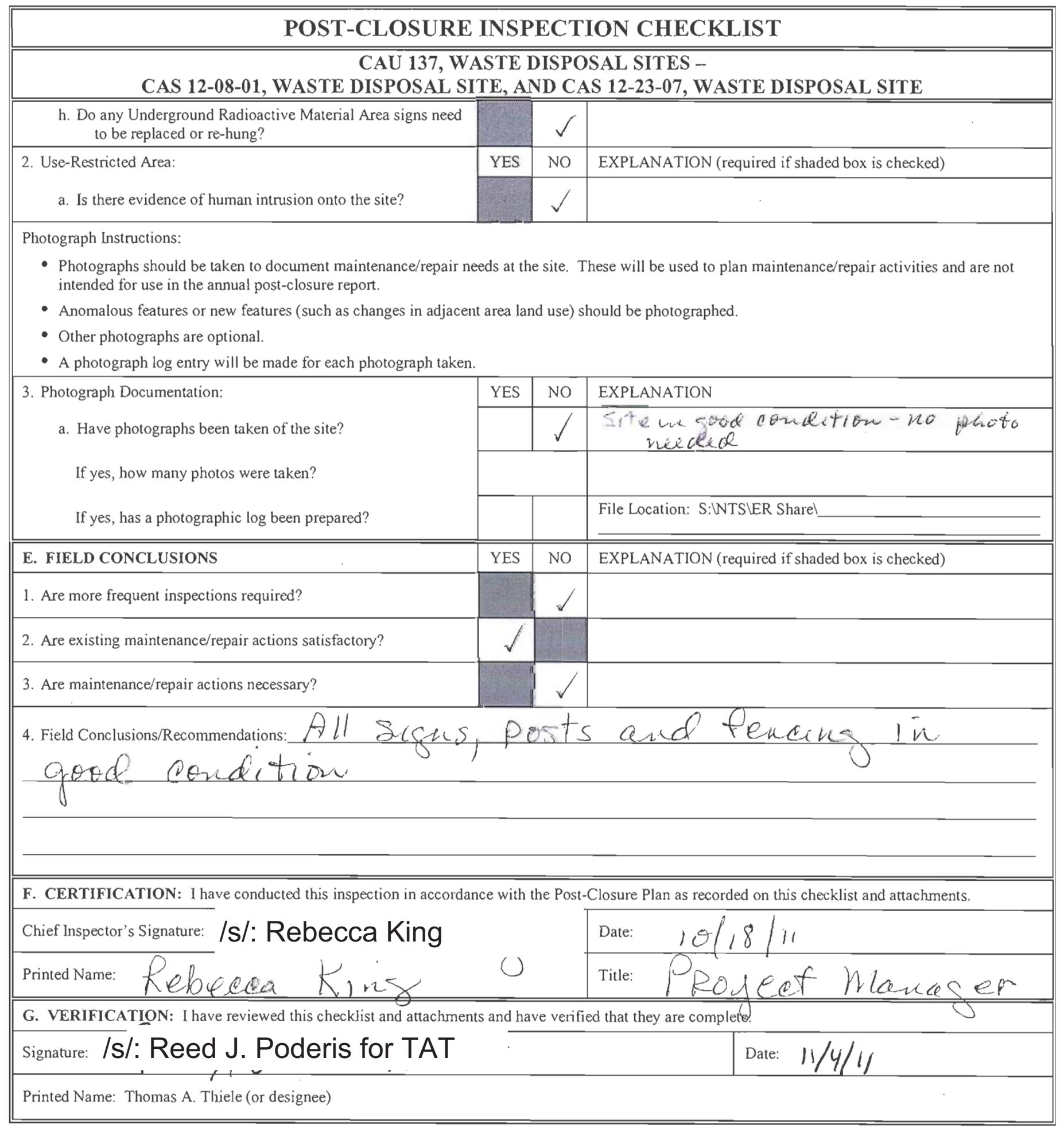




\section{CAU 139: WASTE DISPOSAL SITES}


THIS PAGE INTENTIONALLY LEFT BLANK 


\section{POST-CLOSURE INSPECTION CHECKLIST}

\section{CAU 139, WASTE DISPOSAL SITES - CAS 06-19-03, WASTE DISPOSAL TRENCHES}

\begin{tabular}{|c|c|c|}
\hline Inspection Date and Time: $\quad i / / 8 / 11$ & $1: 40 \mathrm{pm}$ & Reason for Inspection: Annual \\
\hline Date of Last Post-Closure Inspection: $/ / / q$ & & Reason for Last Post-Closure Inspection: \\
\hline
\end{tabular}

Responsible Entity: NSTec Environmental Restoration, Nevada National Security Site, Mercury, Nevada

Responsible Facility Owner: Thomas A. Thiele, Project Manager, Industrial Sites, Environmental Restoration Project

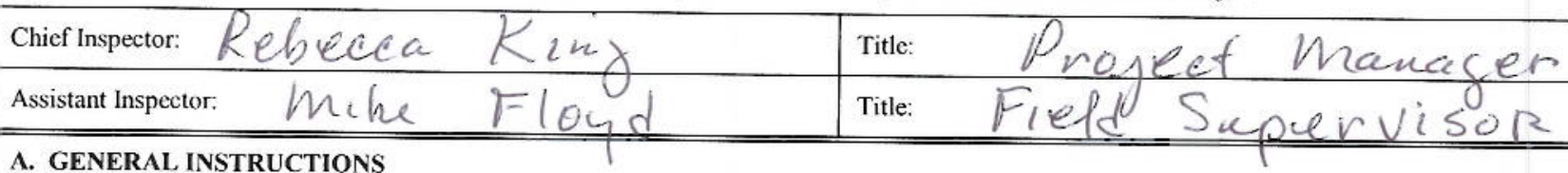

- Complete all checklist items.

- If a SHADED BOX is checked, provide detailed information and/or appropriate references to other documents that have the information.

- All documentation must be legible and clear.

\begin{tabular}{|l|l|l|l|l}
\hline B. PREPARATION (To be completed prior to site visit) & YES & NO & EXPLANATION (required if
\end{tabular}

1. Has the Post-Closure Plan been reviewed?

2. Have the previous inspection reports been reviewed?

3. Were anomalies or trends detected on previous inspections?

4. Were maintenance or repair activities performed since the last inspection?

a. If yes, has site repair resulted in a change from as-built conditions?

b. If yes (to $4 a$ ), are revised as-built plans available that reflect repair changes?

\section{SITE INSPECTION PREPARATION}

Assemble the following, as needed, to conduct inspections:

- Radio, pager, etc.

- Previous letter report, inspection checklists, repair records, and as-built plans

- Camera, digital storage drive, extra batteries, and other miscellaneous support equipment

\section{SITE INSPECTION}

- The site inspection is a walking inspection of the entire site including the perimeter and sufficient transects to be able to inspect the entire surface and all features specifically described in this checklist. The checklist should be completed during the site inspection.

- If a shaded box is checked, add detailed comments to document the results of the site inspection. Information provided should be of sufficient detail to enable reconstruction of observations regarding field conditions. The completed checklist is part of the field record of the inspection.

- Field notes taken to assist in completion of this checklist will become part of the inspection record. No form is specified for field notes, and additional field notes are not required if the checklist and associated attachments adequately describe site conditions.

1. Site Markers:

a. Have any monuments been damaged?

b. Are all use restriction signs legible?

c. Are any use restriction signs damaged or missing?

d. How many damaged or missing signs need to be replaced?

e. Are any use restriction signs down?

f. How many down signs need to be re-hung?

\begin{tabular}{|c|c|c||}
\hline YES & NO & EXPLANATION (required if shaded box is checked) \\
\hline & $\checkmark$ & \\
\hline$\checkmark$ & & \\
\hline & $\checkmark$ & \\
\hline & $\checkmark$ & \\
\hline & $\checkmark$ & \\
\hline & & \\
\hline
\end{tabular}




\section{POST-CLOSURE INSPECTION CHECKLIST}

\section{CAU 139, WASTE DISPOSAL SITES - CAS 06-19-03, WASTE DISPOSAL TRENCHES}

\section{Waste Unit Cover}

a. Is there evidence of settling?

b. Is there evidence of erosion (wind or water)?

c. Is there evidence of human intrusion onto the site?

d. Is there evidence of large animal intrusion onto the site?

\begin{tabular}{|r|r|r||}
\hline YES & NO & EXPLANATION (required if shaded box is checked) \\
\hline & $\checkmark$ & \\
\hline & $\checkmark$ & \\
\hline & $\checkmark$ & \\
\hline & $\checkmark$ & \\
\hline
\end{tabular}

Photograph Instructions:

- Photographs should be taken to document maintenance/repair needs at the site. These will be used to plan maintenance/repair activities and are not intended for use in the annual post-closure report.

- Anomalous features or new features (such as changes in adjacent area land use) should be photographed.

- Other photographs are optional.

- A photograph log entry will be made for each photograph taken.

\begin{tabular}{|c|c|c|c|}
\hline 3. Photograph Documentation: & YES & NO & EXPLANATION \\
\hline a. Have photographs been taken of the site? & $\sqrt{ }$ & & \\
\hline If yes, how many photos were taken? & & & \\
\hline If yes, has a photographic log been prepared? & $\sqrt{ }$ & & $\begin{array}{l}\text { File Location: S:INTS\ER Share Photos\CAU } 13912011 \\
11-8-2011 \text { lnspeetions }\end{array}$ \\
\hline E. FIELD CONCLUSIONS & YES & NO & EXPLANATION (required if shaded box is checked) \\
\hline 1. Are more frequent inspections required? & & $\checkmark$ & \\
\hline 2. Are existing maintenance/repair actions satisfactory & & & \\
\hline 3. Are maintenance/repair actions necessary? & & & \\
\hline 4. Is there an imminent hazard to the integrity of the la & & & \\
\hline $\begin{array}{l}\text { 5. Field Conclusions/Recommendations: } 2, t e \\
\text { Che in covel }\end{array}$ & & & $\begin{array}{l}\text { nage, aude@o } \\
\text { ssues. }\end{array}$ \\
\hline
\end{tabular}

F. CERTIFICATION: I have conducted this inspection in accordance with the Post-Closure Plan as recorded on this checklist and attachments.

Chief Inspector's Signature: /s/: Rebecca King

Printed Name:

$$
\text { Rebecea }
$$

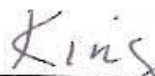

$U$

G. VERIFICATION: I have reviewed this checklist and attachments and have verified that they are complete

Signature: /s/: Reed J. Poderis for TAT
Date

Printed Name: Thomas A. Thiele (or designee) 


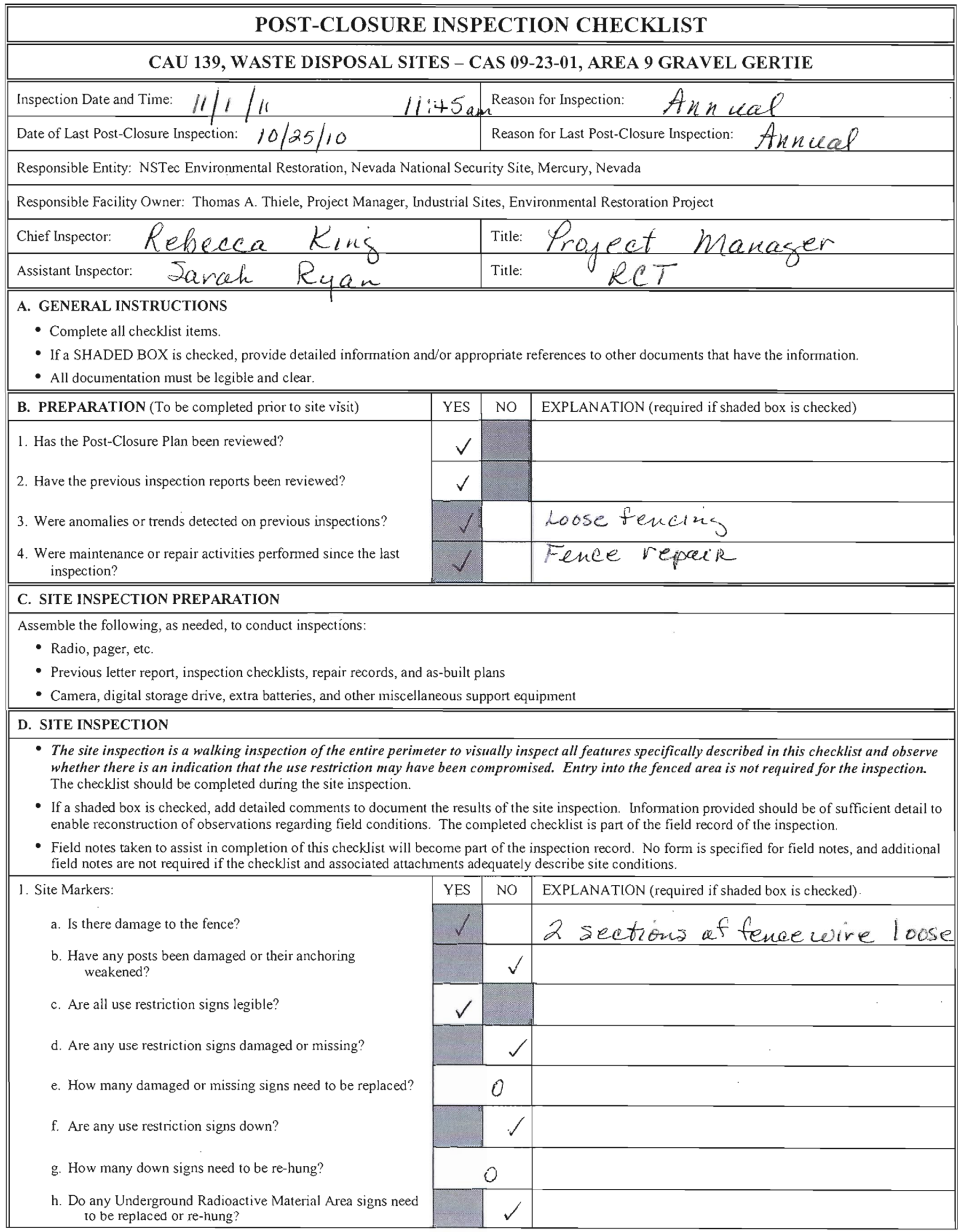




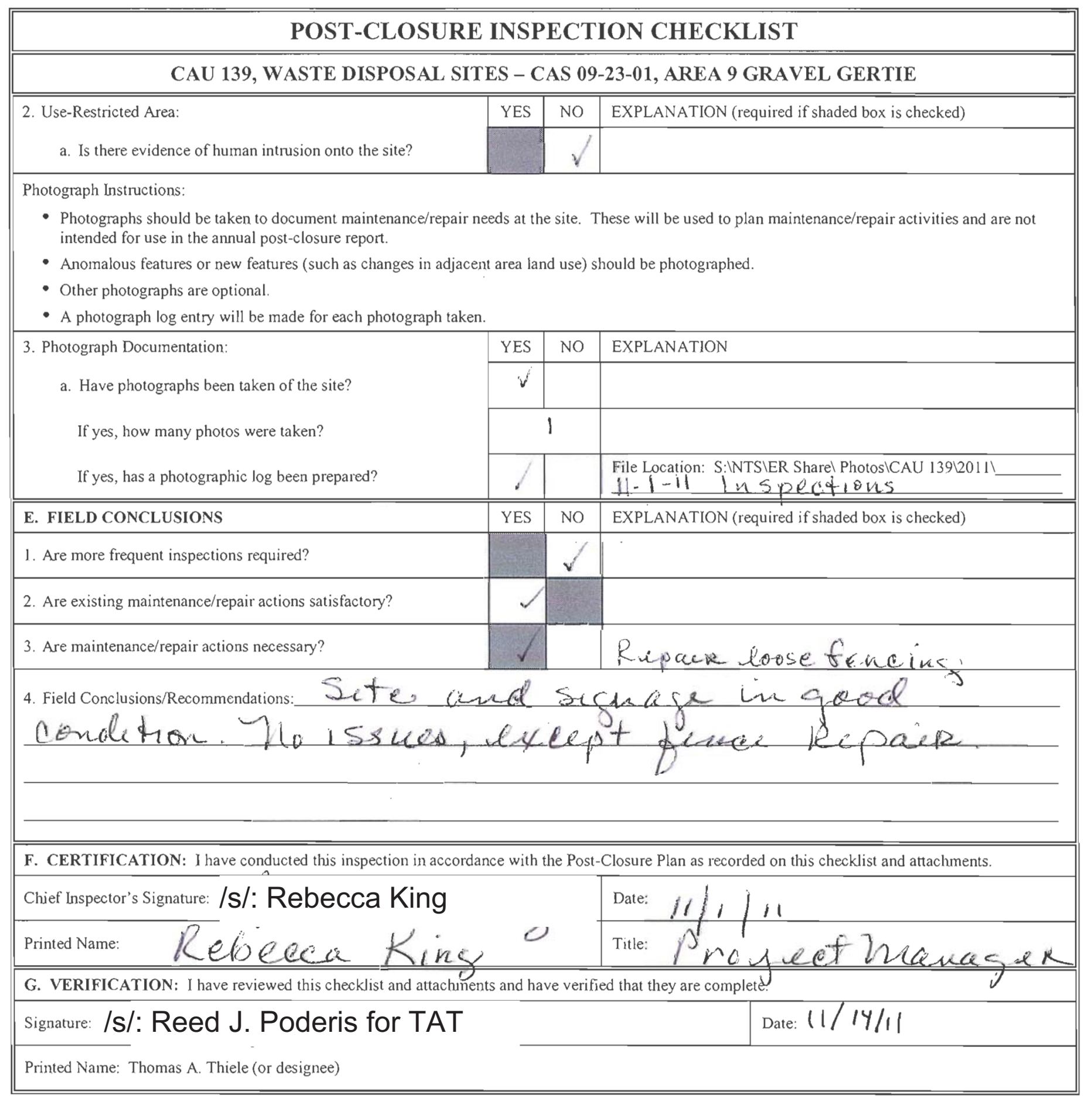


CAU 140: WASTE DUMPS, BURN PITS, AND STORAGE AREA 
THIS PAGE INTENTIONALLY LEFT BLANK 


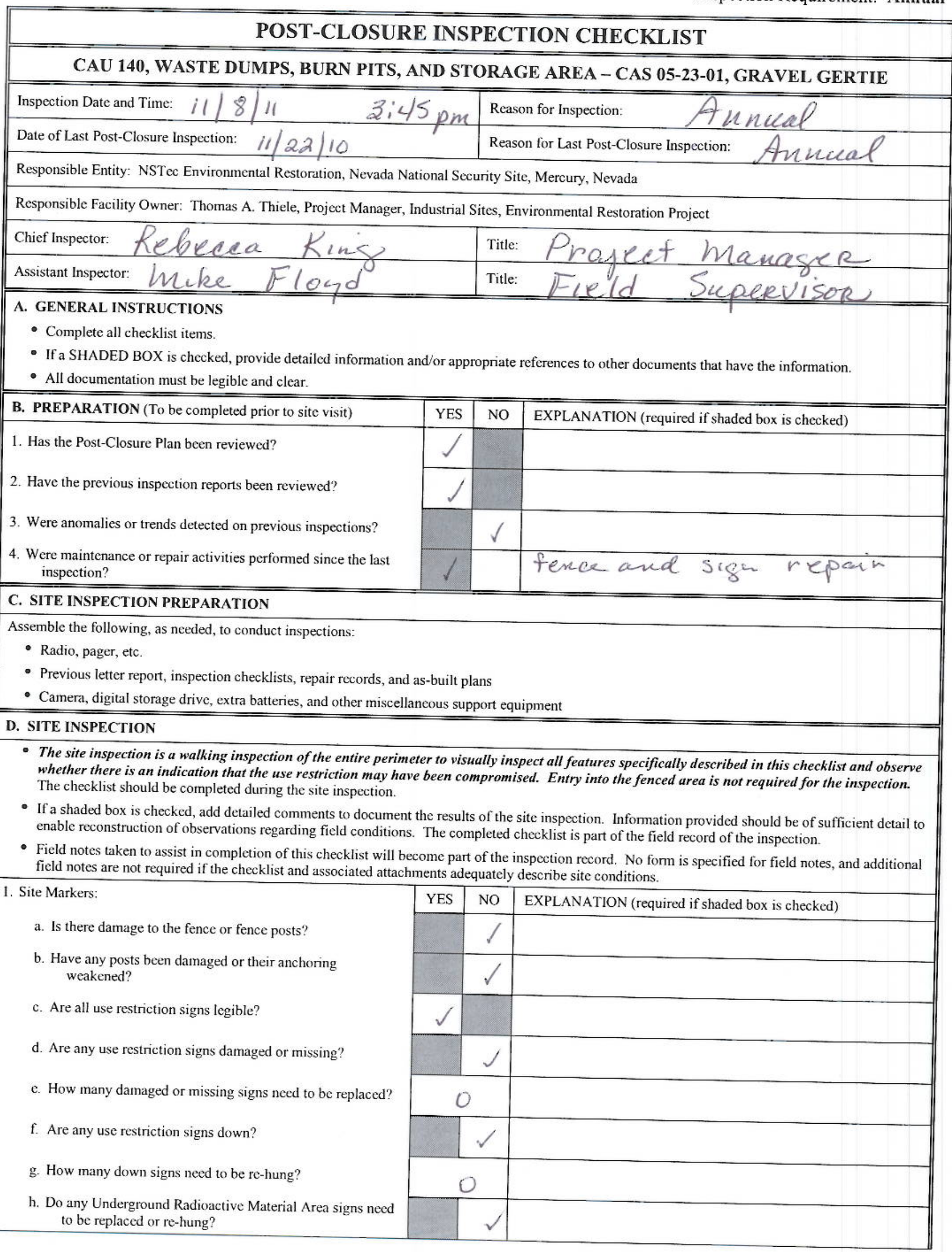




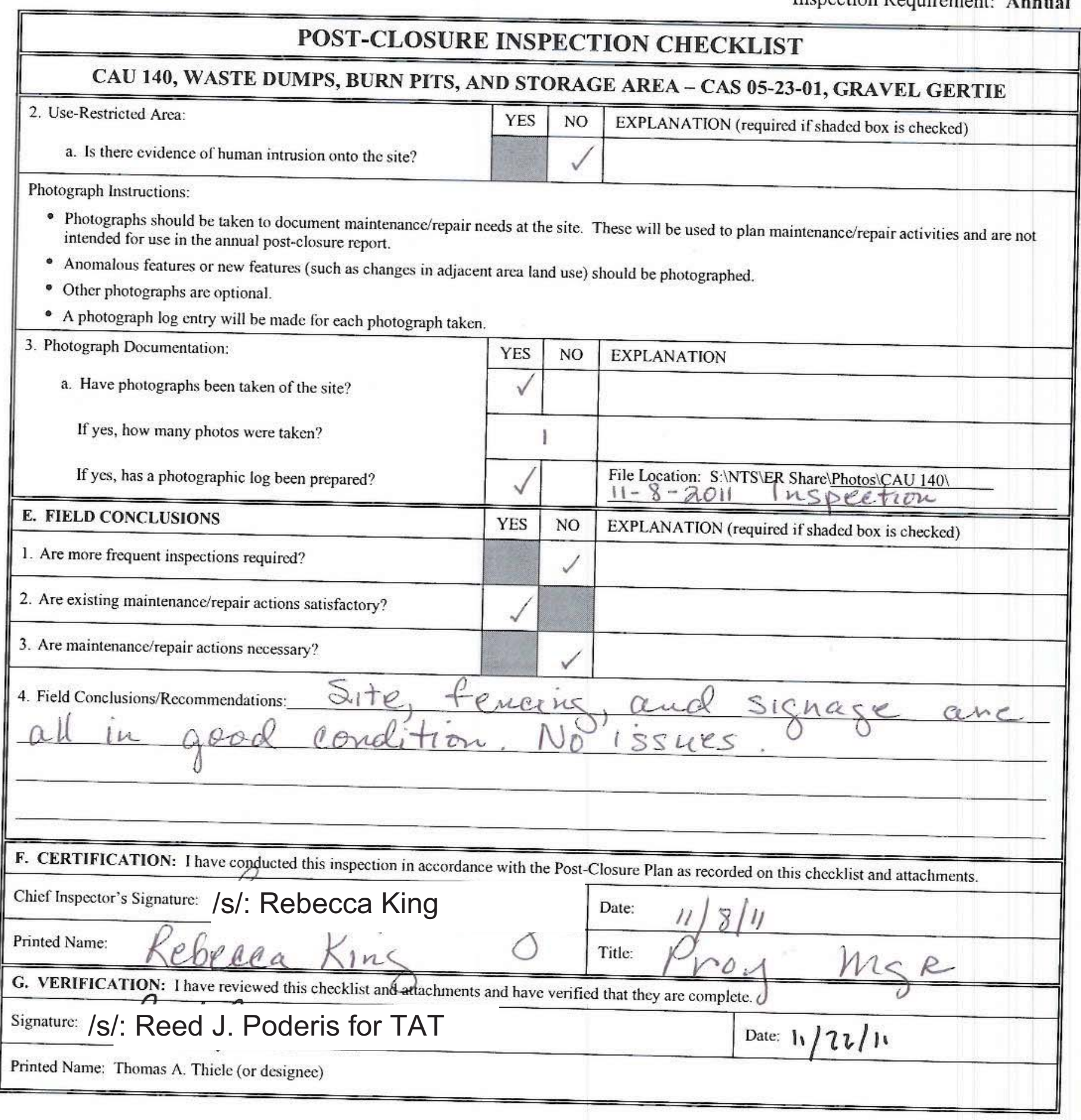




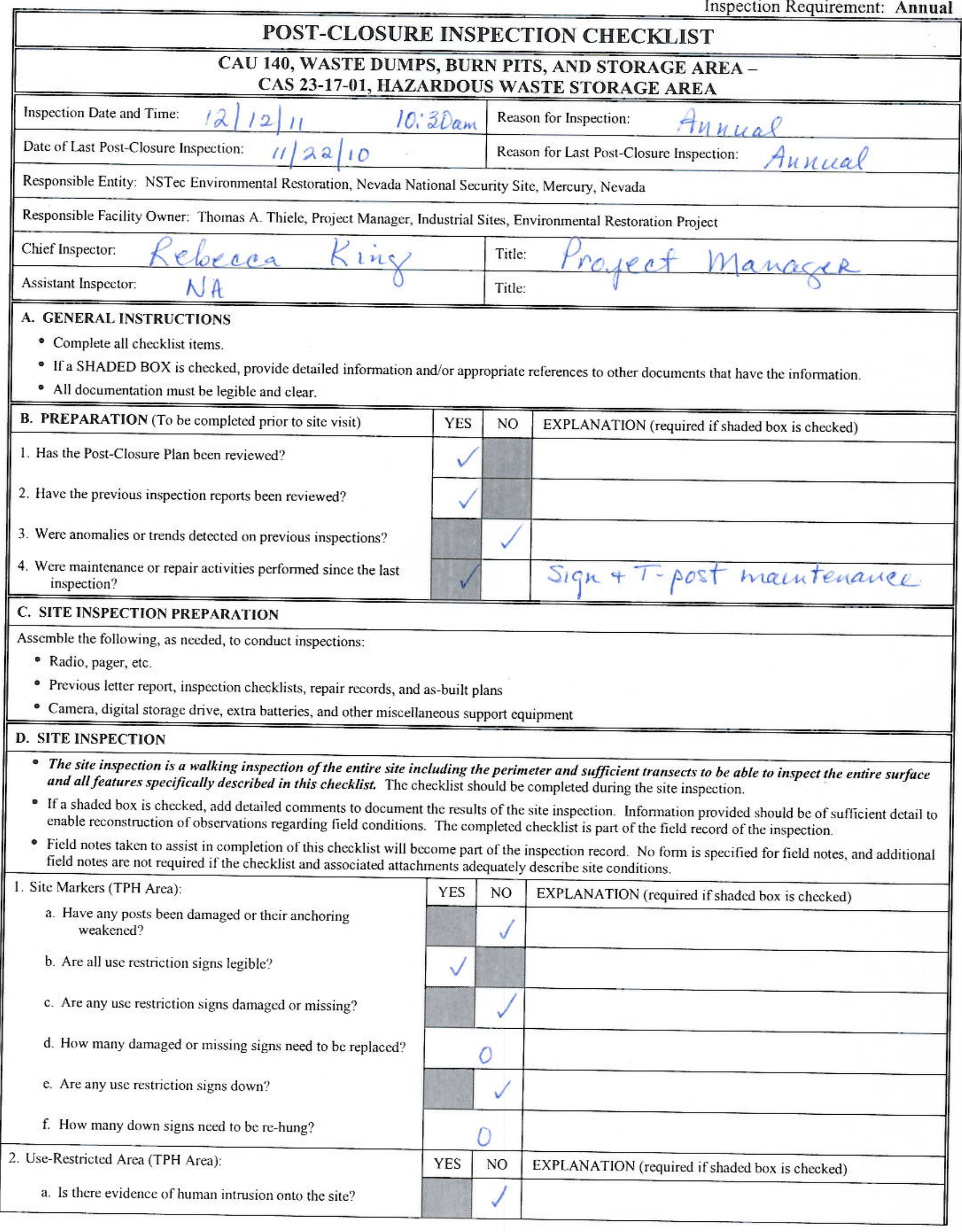




\section{POST-CLOSURE INSPECTION CHECKLIST}

\section{CAU 140, WASTE DUMPS, BURN PITS, AND STORAGE AREA - CAS 23-17-01, HAZARDOUS WASTE STORAGE AREA}

\section{Site Markers (Landfill Area): \\ a. Have any posts been damaged or their anchoring weakened? \\ b. Are all use restriction signs legible? \\ c. Are any use restriction signs damaged or missing? \\ d. How many damaged or missing signs need to be replaced? \\ e. Are any use restriction signs down? \\ f. How many down signs need to be re-hung?}

4. Use-Restricted Area (Landfill Area):

a. Is there evidence of human intrusion onto the site?

\begin{tabular}{|c|c|l||}
\hline YES & NO & EXPLANATION (required if shaded box is checked) \\
\hline & $\checkmark$ & \\
\hline & & \\
\hline & $\checkmark$ & \\
\hline & 0 & \\
\hline & $\checkmark$ & \\
\hline & 0 & \\
\hline YES & NO & EXPLANATION (required if shaded box is checked) \\
\hline & & \\
\hline
\end{tabular}

Photograph Instructions:

- Photographs should be taken to document maintenance/repair needs at the site. These will be used to plan maintenance/repair activities and are not intended for use in the annual post-closure report.

- Anomalous features or new features (such as changes in adjacent area land use) should be photographed.

- Other photographs are optional.

- A photograph log entry will be made for each photograph taken.

5. Photograph Documentation:

a. Have photographs been taken of the site?

If yes, how many photos were taken?

If yes, has a photographic log been prepared?

E. FIELD CONCLUSIONS

1. Are more frequent inspections required?

2. Are existing maintenance/repair actions satisfactory?

3. Are maintenance/repair actions necessary?

4. Field Conclusions/Recommendations:- Site a d RAK $12 / 1 / 4$

Good condition dig - signage are in

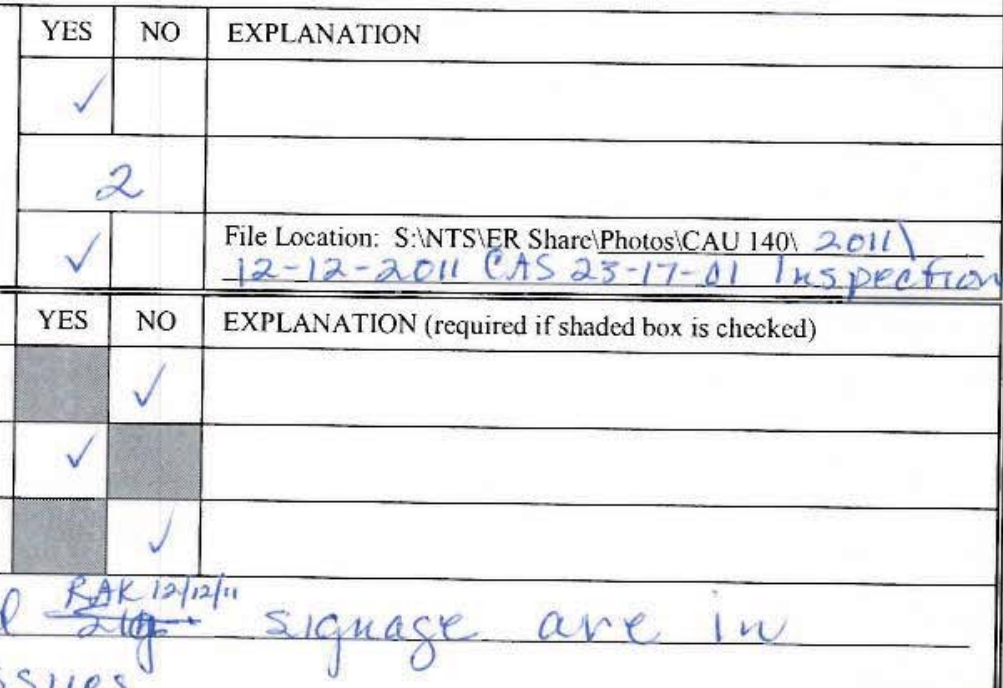

0

F. CERTIFICATION: I have conducted this inspection in accordance with the Post-Closure Plan as recorded on this checklist and attachments.

Chief Inspector's Signature; /s/: Rebecca King

Printed Name: Rebecea Kins

0

Ditle: Project Mlanacen

G. VERIFICATION: I have reviewed this checklist and attachments and have verified that they are complete.

Signature: /s/: Reed J. Poderis for TAT

Printed Name: Thomas A. Thiele (or designee) 
CAU 143: AREA 25 CONTAMINATED WASTE DUMPS 
THIS PAGE INTENTIONALLY LEFT BLANK 


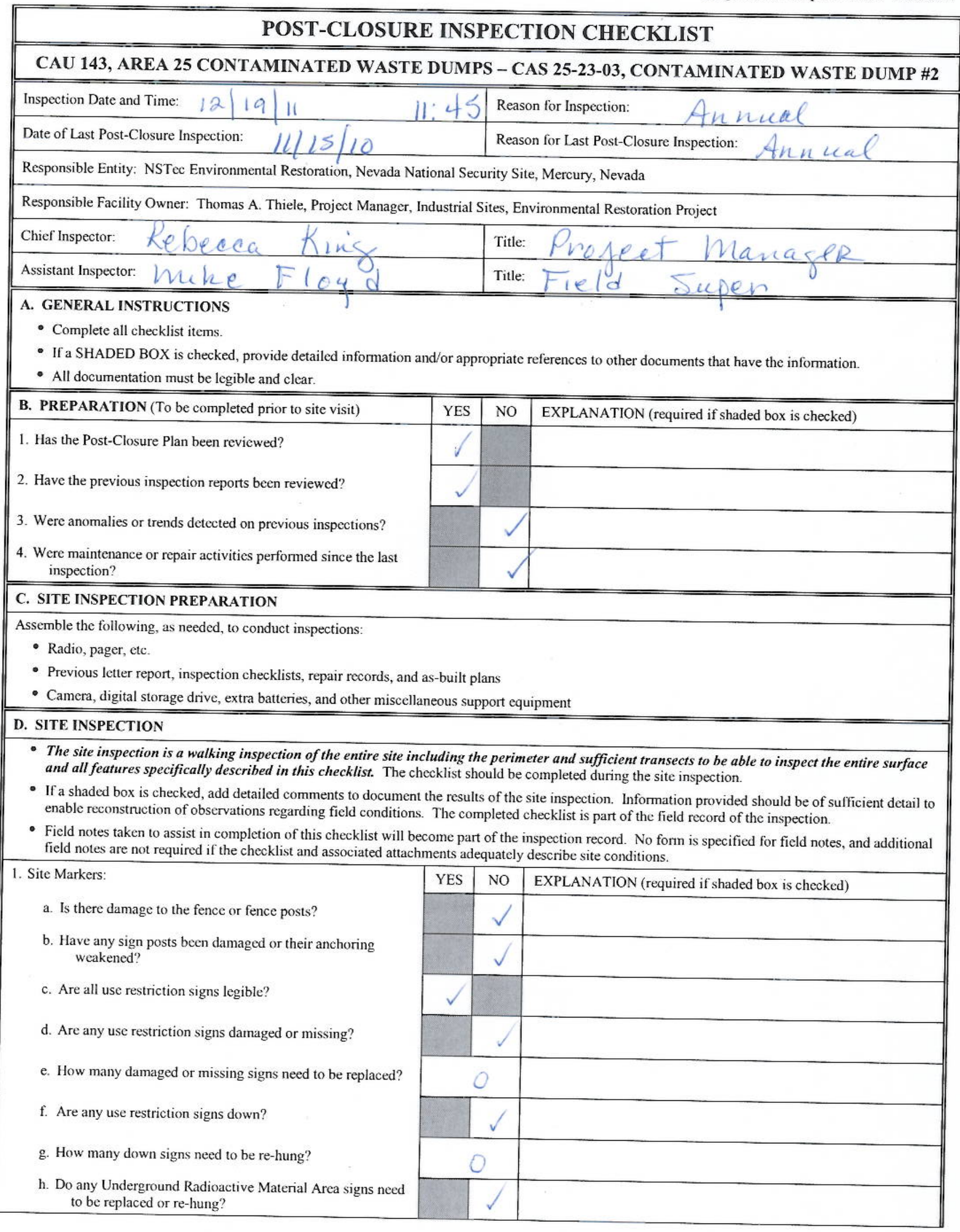




\section{POST-CLOSURE INSPECTION CHECKLIST}

\section{CAU 143, AREA 25 CONTAMINATED WASTE DUMPS - CAS 25-23-03, CONTAMINATED WASTE DUMP \#2}

2. Use-Restricted Area:

a. Is there evidence of human intrusion onto the site?

Photograph Instructions:

- Photographs should be taken to document maintenance/repair needs at the site. These will be used to plan maintenance/repair activities and are not intended for use in the annual post-closure report.

- Anomalous features or new features (such as changes in adjacent area land use) should be photographed.

- Other photographs are optional.

- A photograph log entry will be made for each photograph taken.

3. Photograph Documentation:

a. Have photographs been taken of the site?

If yes, how many photos were taken?

If yes, has a photographic log been prepared?

\section{E. FIELD CONCLUSIONS \\ 1. Are more frequent inspections required?}

2. Are existing maintenance/repair actions satisfactory?

3. Are maintenance/repair actions necessary?

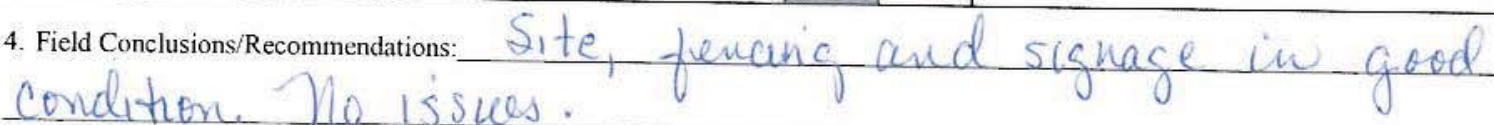

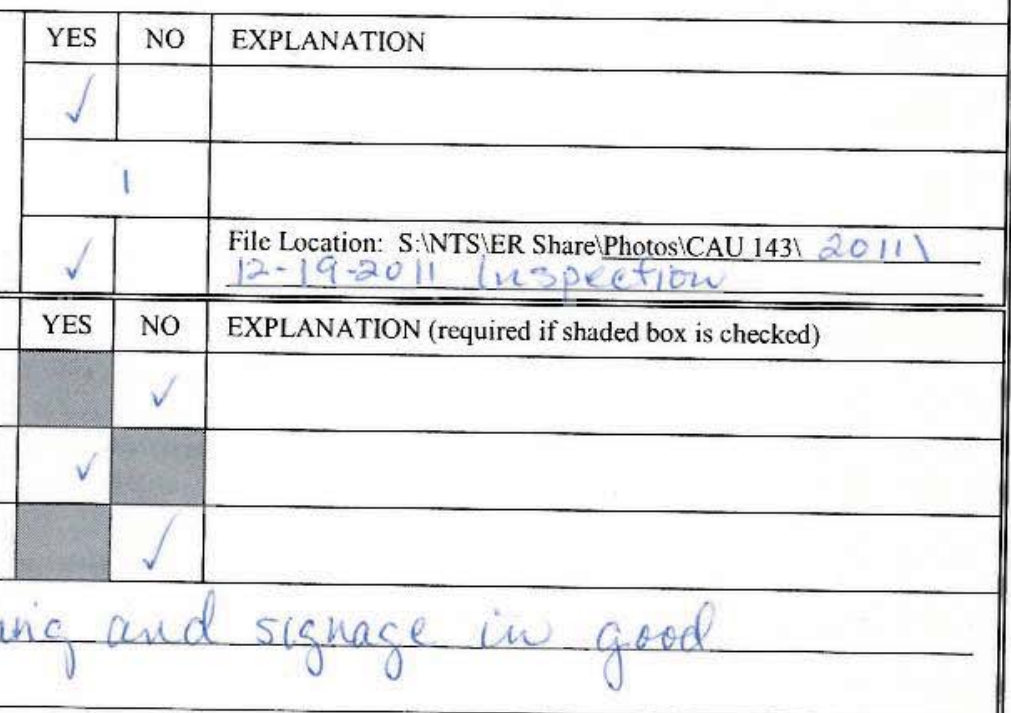

F. CERTIFICATION: I have conducted this inspection in accordance with the Post-Closure Plan as recorded on this checklist and attachments.

Chief Inspector's Signature: /s/: Rebecca King

Printed Name: Reberea KiliG

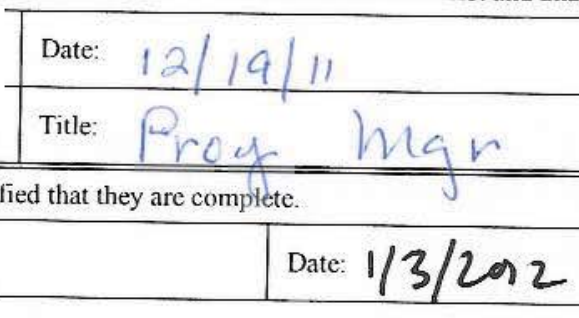

G. VERIFICATION: I have reviewed this checklist and attachments and have verified that they are complete

Signature: /s/: Reed J. Poderis for TAT

Printed Name: Thomas A. Thicle (or designee) 
POST-CLOSURE INSPECTION CHECKLIST

\section{CAU 143, AREA 25 CONTAMINATED WASTE DUMPS - CAS 25-23-09, CONTAMINATED WASTE DUMP \#1}

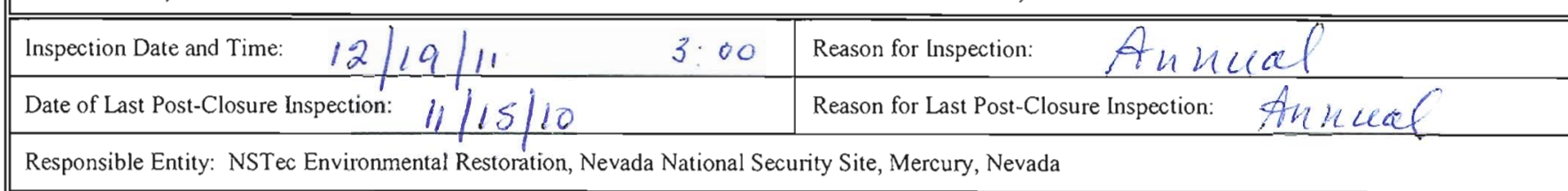

Responsible Facility Owner: Thomas A. Thiele, Project Manager, Industrial Sites, Environmental Restoration Project

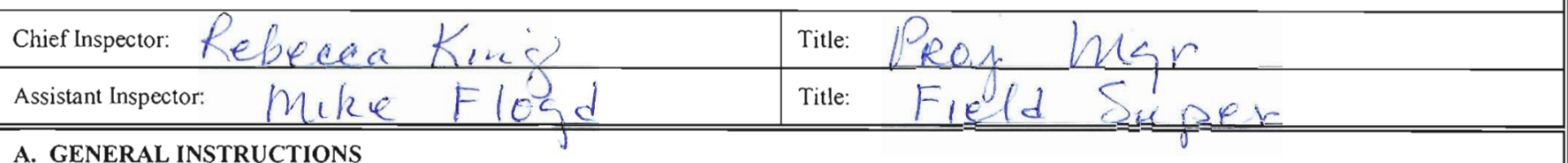

A. GENERAL INSTRUCTIONS

- Complete all checklist items.

- If a SHADED BOX is checked, provide detailed information and/or appropriate references to other documents that have the information.

- All documentation must be legible and clear.

\begin{tabular}{|c|c|c|c|}
\hline B. PREPARATION (To be completed prior to site visit) & YES & $\mathrm{NO}$ & EXPLANATION (required if shaded box is checked) \\
\hline \multicolumn{4}{|l|}{ 1. Has the Post-Closure Plan been reviewed? } \\
\hline \multicolumn{4}{|l|}{ 2. Have the previous inspection reports been reviewed? } \\
\hline \multicolumn{4}{|l|}{ 3. Were anomalies or trends detected on previous inspections? } \\
\hline $\begin{array}{l}\text { 4. Were maintenance or repair activities performed since the last } \\
\text { inspection? }\end{array}$ & & & repar \\
\hline
\end{tabular}

\section{SITE INSPECTION PREPARATION}

Assemble the following, as needed, to conduct inspections:

- Radio, pager, etc.

- Previous letter report, inspection checklists, repair records, and as-built plans

- Camera, digital storage drive, extra batteries, and other miscellaneous support equipment

\section{SITE INSPECTION}

- The site inspection is a walking inspection of the entire perimeter to visually inspect all features specifically described in this checklist and observe whether there is an indication that the use restriction may have been compromised. Entry into the fenced area is not required for the inspection.

The checklist should be completed during the site inspection.

- If a shaded box is checked, add detailed comments to document the results of the site inspection. Information provided should be of sufficient detail to enable reconstruction of observations regarding field conditions. The completed checklist is part of the field record of the inspection.

- Field notes taken to assist in completion of this checklist will become part of the inspection record. No form is specified for field notes, and additional field notes are not required if the checklist and associated attachments adequately describe site conditions.

1. Site Markers:

a. Is there damage to the fence or fence posts?

b. Have any sign posts been damaged or their anchoring weakened?

c. Are all use restriction signs legible?

d. Are any of the 10 use restriction signs damaged or missing?

e. How many damaged or missing signs need to be replaced?

f. Are any use restriction signs down?

g. How many down signs need to be re-hung?

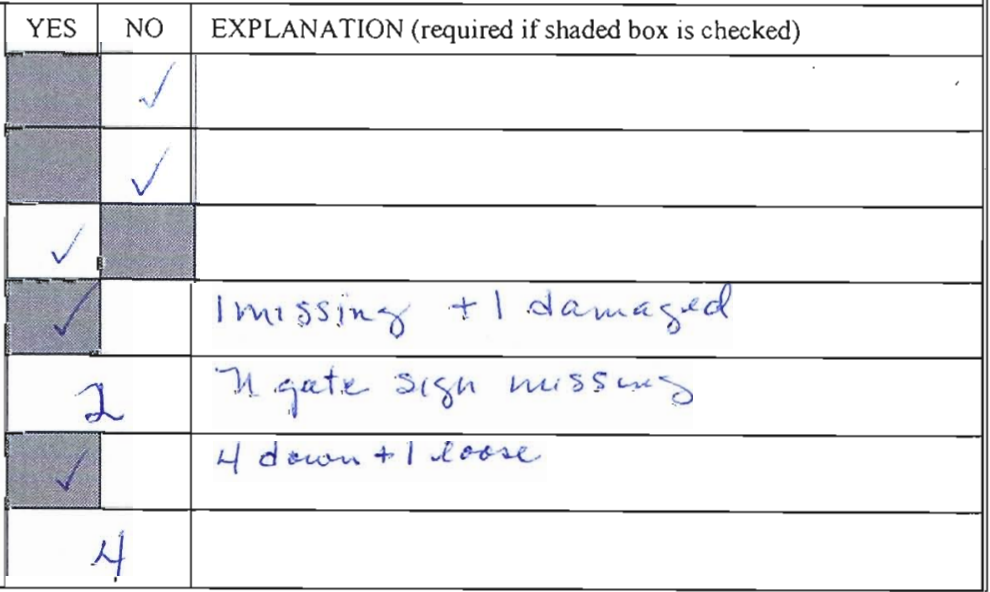




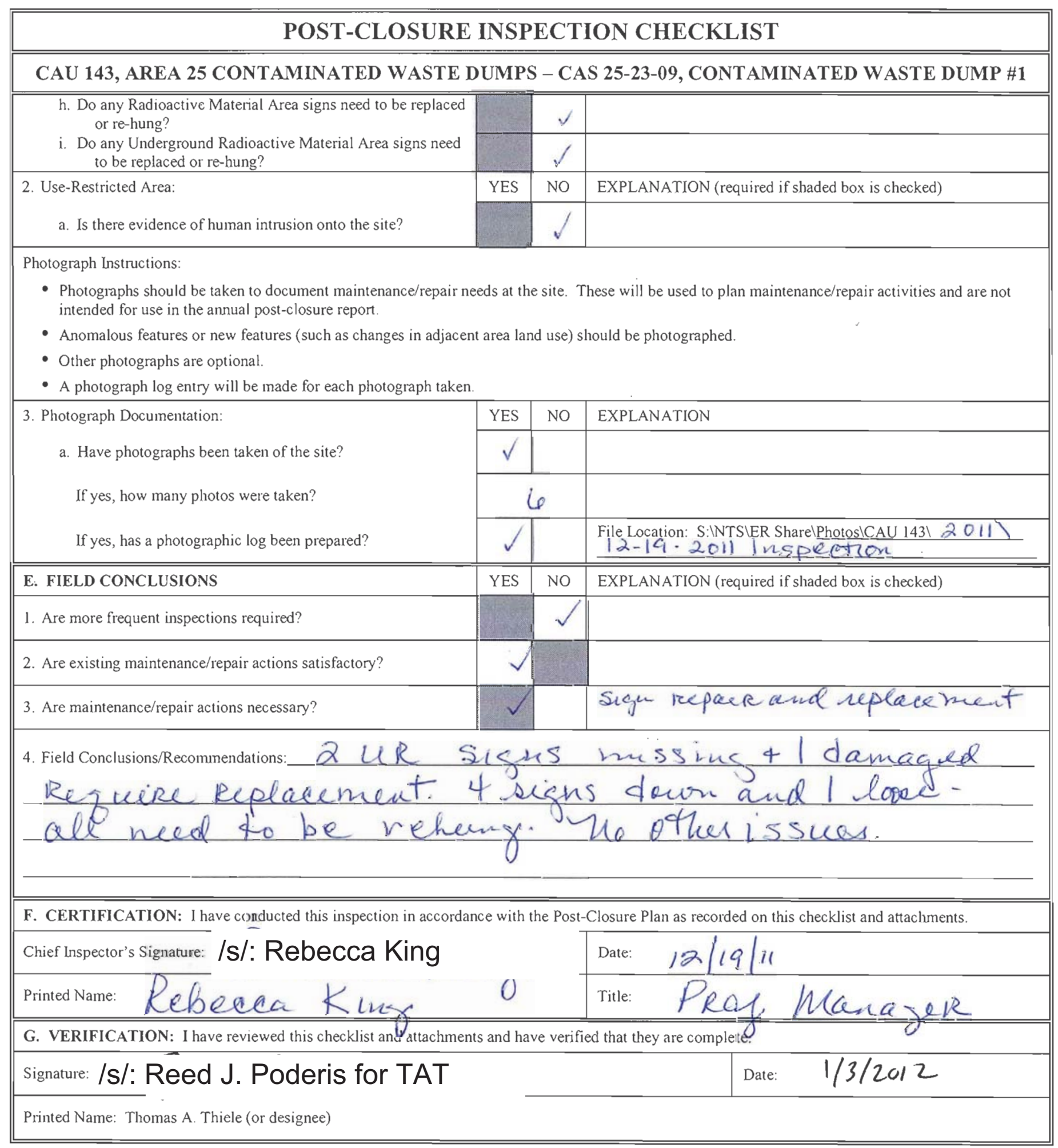


CAU 145: WELLS AND STORAGE HOLES 
THIS PAGE INTENTIONALLY LEFT BLANK 


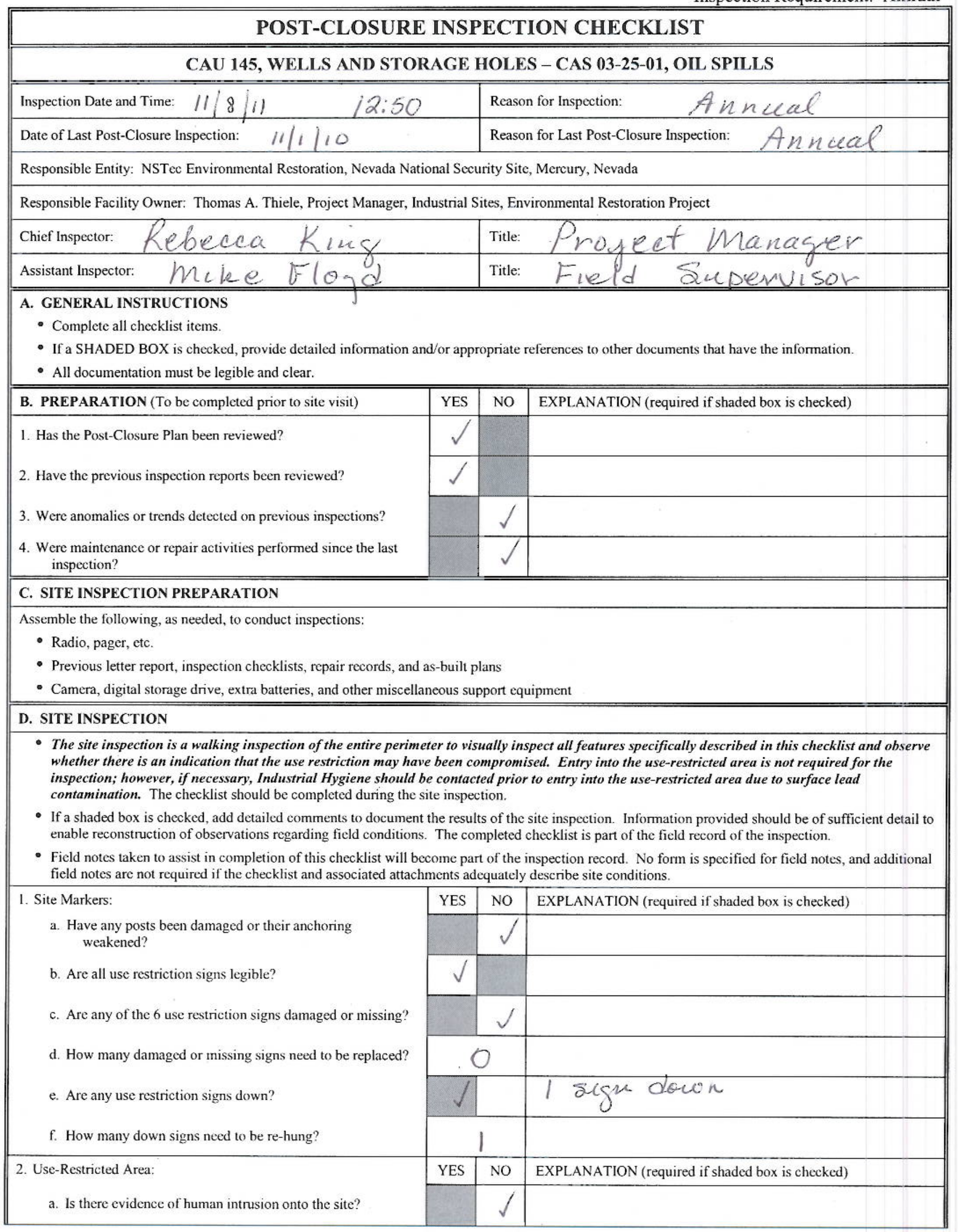




\section{POST-CLOSURE INSPECTION CHECKLIST}

\section{CAU 145, WELLS AND STORAGE HOLES - CAS 03-25-01, OIL SPILLS}

Photograph Instructions:

- Photographs should be taken to document maintenance/repair needs at the site. These will be used to plan maintenance/repair activities and are not intended for use in the annual post-closure report.

- Anomalous features or new features (such as changes in adjacent area land use) should be photographed.

- Other photographs are optional.

- A photograph log entry will be made for each photograph taken.

3. Photograph Documentation:

a. Have photographs been taken of the site?

If yes, how many photos were taken?

If yes, has a photographic log been prepared?

\begin{tabular}{|c|c|c|}
\hline YES & NO & EXPLANATION \\
\hline \multicolumn{3}{|c|}{ i } \\
\hline & & 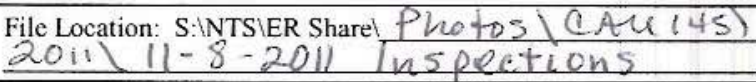 \\
\hline YES & NO & EXPLANATION (required if shaded box is checked) \\
\hline & & $118 \prod^{n}$ \\
\hline & & Lerhans I sign \\
\hline
\end{tabular}

3. Are maintenance/repair actions necessary?

sisin 13

4. Field Conclusions/Recommendations: $1 L R$

re-hanging, Other wise site condition.

F. CERTIFICATION: I have conducted this inspection in accordance with the Post-Closure Plan as recorded on this checklist and attachments.

Chief Inspector's Signature: /s/: Rebecca King

Printed Name:
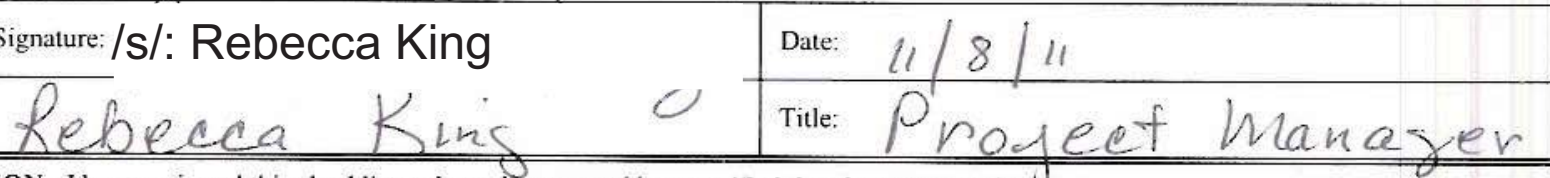

G. VERIFICATION: I have reviewed this checklist and attachments and have verified that they are complete.

Signature: /s/: Reed J. Poderis for TAT

Date: $11 / 22 / 1$,

Printed Name: Thomas A. Thicle (or designee) 
CAU 151: SEPTIC SYSTEMS AND DISCHARGE AREA 
THIS PAGE INTENTIONALLY LEFT BLANK 


\begin{tabular}{|c|c|c|c|c|}
\hline \multicolumn{5}{|c|}{ POST-CLOSURE INSPECTION CHECKLIST } \\
\hline \multicolumn{5}{|c|}{$\begin{array}{l}\text { CAU 151, SEPTIC SYSTEMS AND DISCHARGE AREA - CAS 12-03-01, SEWAGE LAGOONS (6) } \\
\text { LAGOON A }\end{array}$} \\
\hline \multicolumn{2}{|l|}{ Date of Last Post-Closure Inspection: $10 / 1 / / 10$} & \multicolumn{3}{|c|}{ Reason for Last Post-Closure Inspection: A $1 \mathrm{rccal}$} \\
\hline \multicolumn{5}{|c|}{ Responsible Facility Owner: Thomas A. Thiele, Project Manager, Industrial Sites, Environmental Restoration Project } \\
\hline \multicolumn{2}{|c|}{ Chief Inspector: Pebecea Kins } & \multicolumn{3}{|c|}{ Title: Proved Manasue } \\
\hline \multicolumn{2}{|l|}{ Assistant Inspector: Kavely Y Ree } & \multicolumn{3}{|c|}{ Title: Latorere } \\
\hline \multicolumn{5}{|c|}{$\begin{array}{l}\text { A. GENERAL INSTRUCTIONS } \\
\text { - Complete all checklist items. } \\
\text { - If a SHADED BOX is checked, provide detailed information and/or appropriate references to other documents that have the information. } \\
\text { - All documentation must be legible and clear. }\end{array}$} \\
\hline B. PREPARATION (To be completed prior to site visit) & YES & NO & EXPLANATION (required if shaded box is checked) & \\
\hline \\
\hline \\
\hline \multicolumn{5}{|l|}{ 3. Were anomalies or trends detected on previous inspections? } \\
\hline \multicolumn{5}{|l|}{$\begin{array}{l}\text { 4. Were maintenance or repair activities performed since the last } \\
\text { inspection? }\end{array}$} \\
\hline \multicolumn{5}{|l|}{ C. SITE INSPECTION PREPARATION } \\
\hline \multirow{3}{*}{$\begin{array}{l}\text { 1. Site Markers: } \\
\text { a. Have any sign posts been damaged or their anchoring } \\
\text { weakened? } \\
\text { b. Are all use restriction signs legible? }\end{array}$} & YES & NO & EXPLANATION (required if shaded box is checked) & \\
\hline & & & & \\
\hline & $v$ & & & \\
\hline \multicolumn{5}{|l|}{ c. Are any of the 6 use restriction signs damaged or missing? } \\
\hline d. How many damaged or missing signs need to be replaced? & \multicolumn{2}{|c|}{0} & & \\
\hline \multicolumn{5}{|l|}{ e. Are any use restriction signs down? } \\
\hline f. How many down signs need to be re-hung? & \multicolumn{2}{|r|}{ 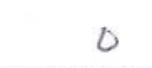 } & & \\
\hline \multirow{2}{*}{$\begin{array}{l}\text { 2. Use-Restricted Area: } \\
\text { a. Is there evidence of human intrusion onto the site? }\end{array}$} & YES & NO & EXPLANATION (required if shaded box is checked) & \\
\hline & & & & \\
\hline
\end{tabular}




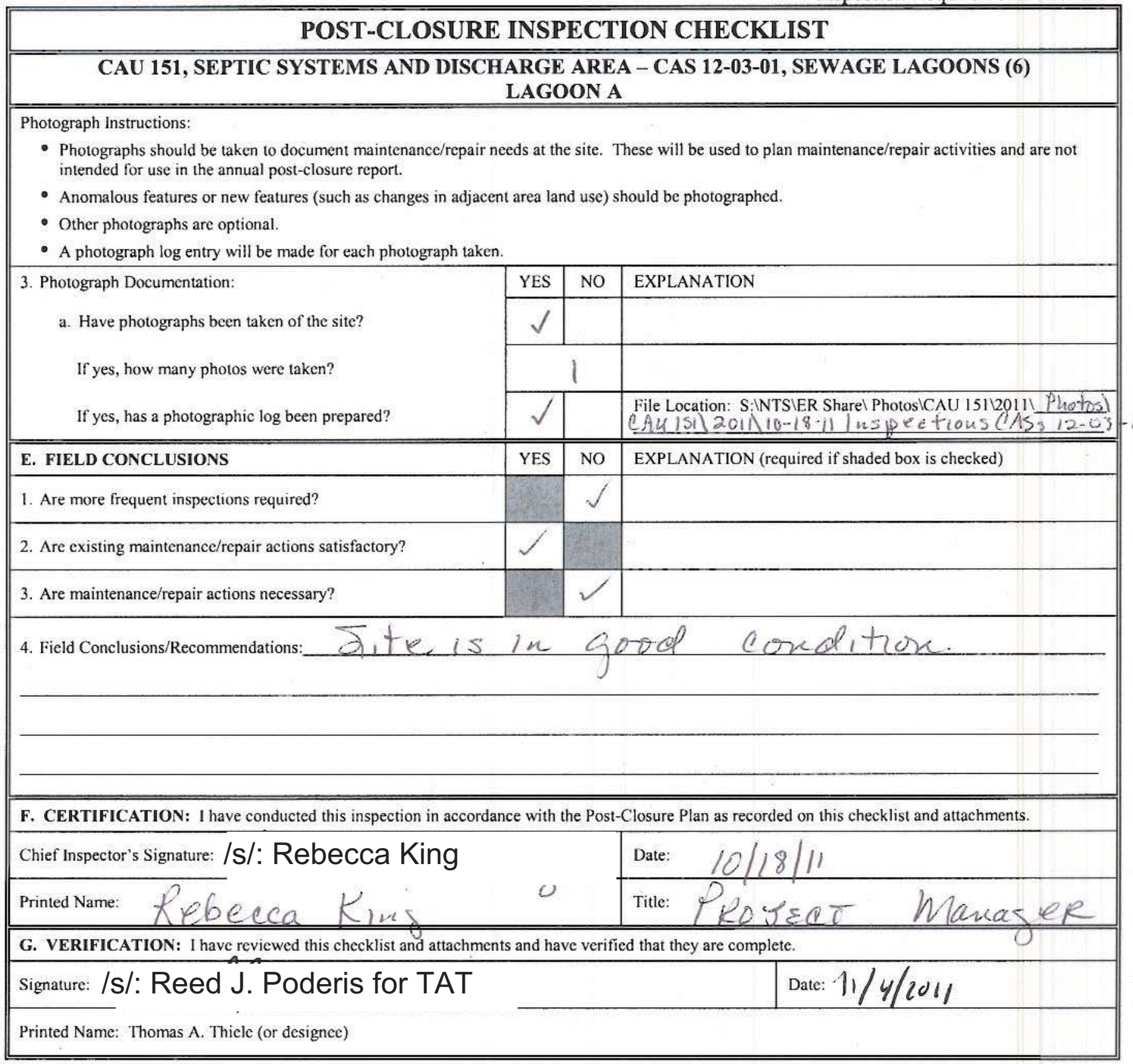


CAU 165: AREA 25 AND 26 DRY WELL AND WASHDOWN AREAS 
THIS PAGE INTENTIONALLY LEFT BLANK 
POST-CLOSURE INSPECTION CHECKLIST

CAU 165, AREA 25 AND 26 DRY WELL AND WASHDOWN AREAS - CAS 25-20-01, LAB DRAIN DRY WELL

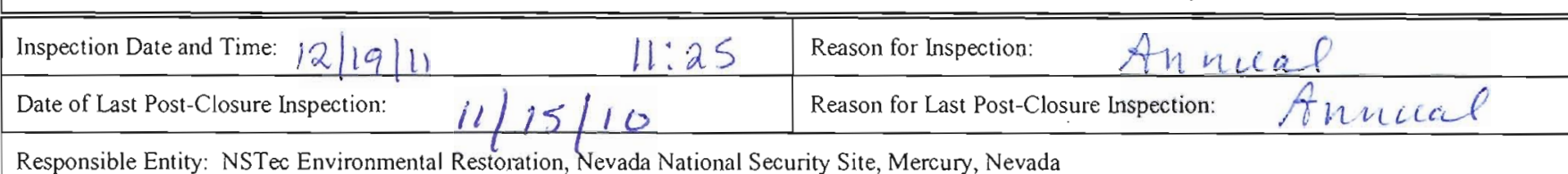

Responsible Entity: NSTec Environmental Restoration, Nevada National Security Site, Mercury, Nevada

Responsible Facility Owner: Thomas A. Thiele, Project Manager, Industrial Sites, Environmental Restoration Project

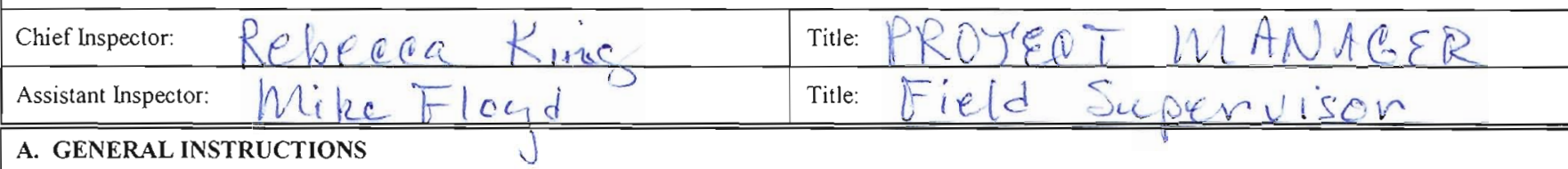

- Complete all checklist items.

- If a SHADED BOX is checked, provide detailed information and/or appropriate references to other documents that have the information.

- All documentation must be legible and clear.

\begin{tabular}{|c|c|c|c|}
\hline B. PREPARATION (To be completed prior to site visit) & YES & $\mathrm{NO}$ & EXPLANATION (required if shaded box is checked) \\
\hline 1. Has the Post-Closure Plan been reviewed? & & & \\
\hline 2. Have the previous inspection reports been reviewed? & & & \\
\hline 3. Were anomalies or trends detected on previous inspections? & & & \\
\hline $\begin{array}{l}\text { 4. Were maintenance or repair activities performed since the last } \\
\text { inspection? }\end{array}$ & & & . \\
\hline
\end{tabular}

\section{SITE INSPECTION PREPARATION}

Assemble the following, as needed, to conduct inspections:

- Radio, pager, etc.

- Previous letter report, inspection checklists, repair records, and as-built plans

- Camera, digital storage drive, extra batteries, and other miscellaneous support equipment

\section{SITE INSPECTION}

- The site inspection is a walking inspection of the entire site including the perimeter and sufficient transects to be able to inspect the entire surface and all features specifically described in this checklist. The checklist should be completed during the site inspection.

- If a shaded box is checked, add detailed comments to document the results of the site inspection. Information provided should be of sufficient detail to enable reconstruction of observations regarding field conditions. The completed checklist is part of the field record of the inspection.

- Field notes taken to assist in completion of this checklist will become part of the inspection record. No form is specified for field notes, and additional field notes are not required if the checklist and associated attachments adequately describe site conditions.

1. Site Markers:

a. Have any posts been damaged or their anchoring weakened?

b. Are all use restriction signs legible?

c. Are any use restriction signs damaged or missing?

d. How many damaged or missing signs need to be replaced?

e. Are any use restriction signs down?

f. How many down signs need to be re-hung?

2. Use-Restricted Area:

a. Is there evidence of human intrusion onto the site?

\begin{tabular}{|c|c|c|c|}
\hline YES & NO & EXPLANATION (required if shaded box is checked) \\
\hline$\sqrt{ }$ & $\checkmark$ & & \\
\hline & & 1 sign loo se om i sicle \\
\hline & & \\
\hline YES & NO & EXPLANATION (required if shaded box is checked) \\
\hline
\end{tabular}


POST-CLOSURE INSPECTION CHECKLIST

\section{CAU 165, AREA 25 AND 26 DRY WELL AND WASHDOWN AREAS - CAS 25-20-01, LAB DRAIN DRY WELL}

Photograph Instructions:

- Photographs should be taken to document maintenance/repair needs at the site. These will be used to plan maintenance/repair activities and are not intended for use in the annual post-closure report.

- Anomalous features or new features (such as changes in adjacent area land use) should be photographed.

- Other photographs are optional.

- A photograph log entry will be made for each photograph taken.

3. Photograph Documentation:

a. Have photographs been taken of the site?

If yes, how many photos were taken?

If yes, has a photographic log been prepared?

\begin{tabular}{|l|l|}
\hline E. FIELD CONCLUSIONS & Yre more frequent inspections required? \\
\hline 2. Are existing maintenance/repair actions satisfactory? & \\
\hline 3. Are maintenance/repair actions necessary? & \\
\hline
\end{tabular}

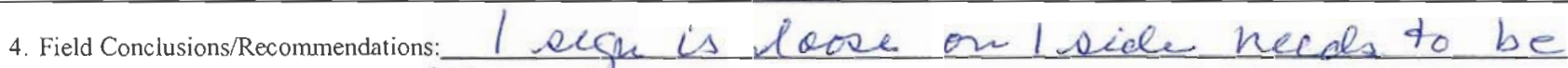
Reattached Wo other issues.

F. CERTIFICATION: I have conducted this inspection in accordance with the Post-Closure Plan as recorded on this checklist and attachments Chief Inspector's Signature: /s/: Rebecca King Printed Name: $\quad$ Rebecea Kuis

G. VERIFICATION: I have reviewed this checklist and attachments and have verified that they are complete. Signature: /s/: Reed J. Poderis for TAT Date: $\quad 1 / 3 / 2012$

Printed Name: Thomas A. Thiele (or designee) 
CAU 168: AREA 25 AND 26 CONTAMINATED MATERIALS AND WASTE DUMPS 
THIS PAGE INTENTIONALLY LEFT BLANK 
Inspection Requirement: Annual (through December 2011) then Every 5 Years (through December 2036)

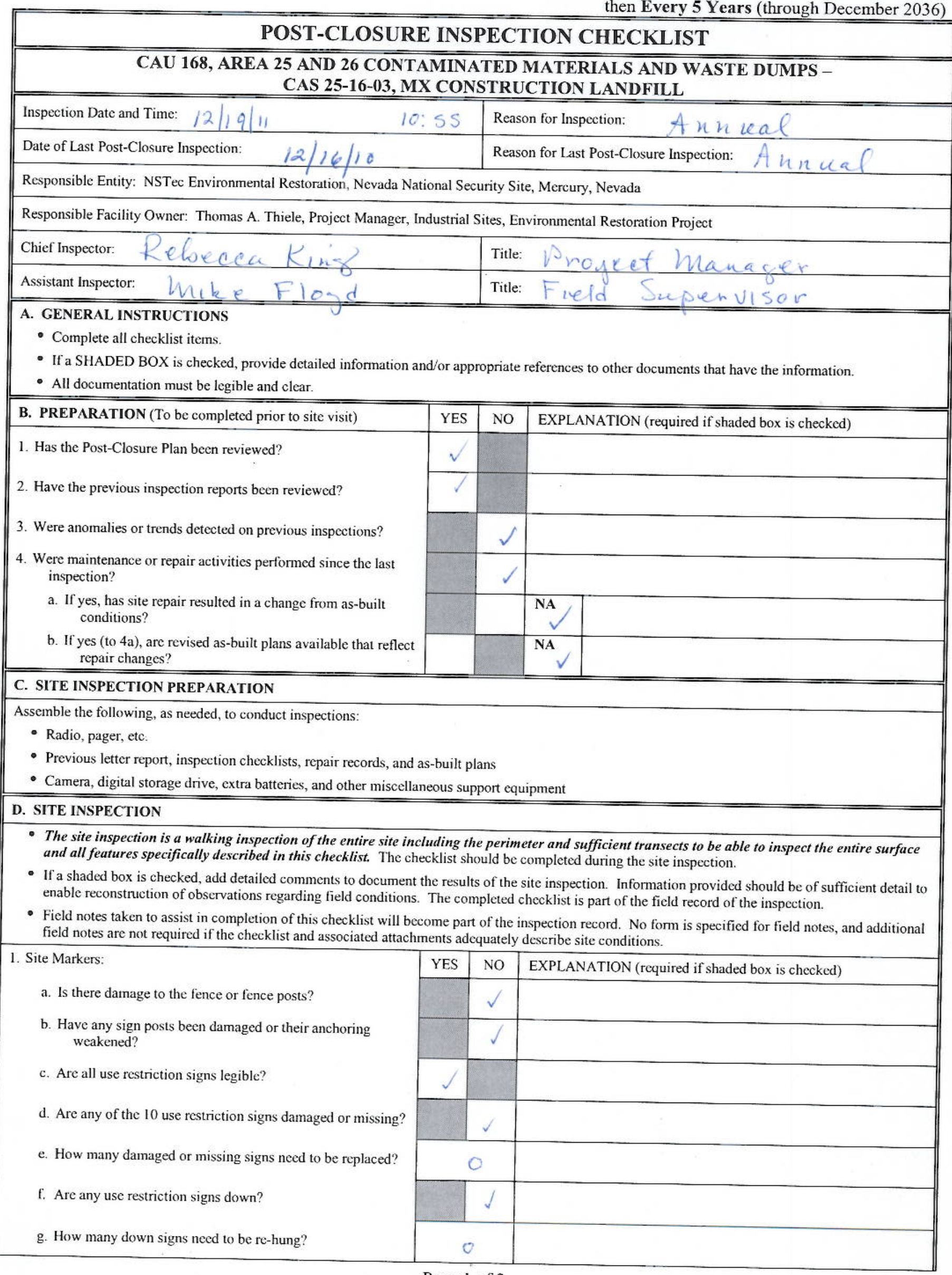

Page 1 of 2 


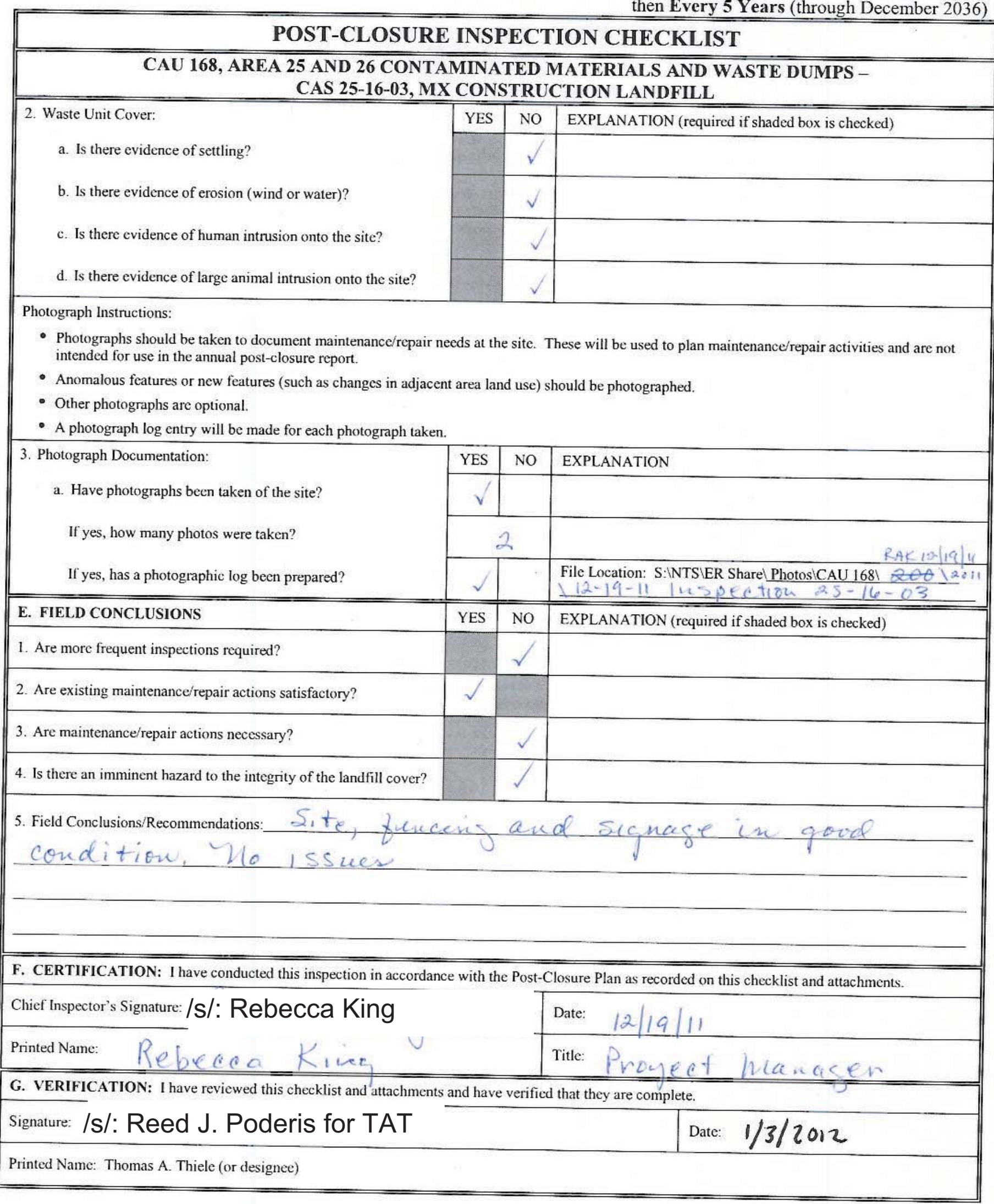


Inspection Requirement: Annual (through December 2011) then Every 5 Years (through December 2036)

POST-CLOSURE INSPECTION CHECKLIST

\section{CAU 168, AREA 25 AND 26 CONTAMINATED MATERIALS AND WASTE DUMPS - CAS 25-23-02, RADIOACTIVE STORAGE RR CARS}

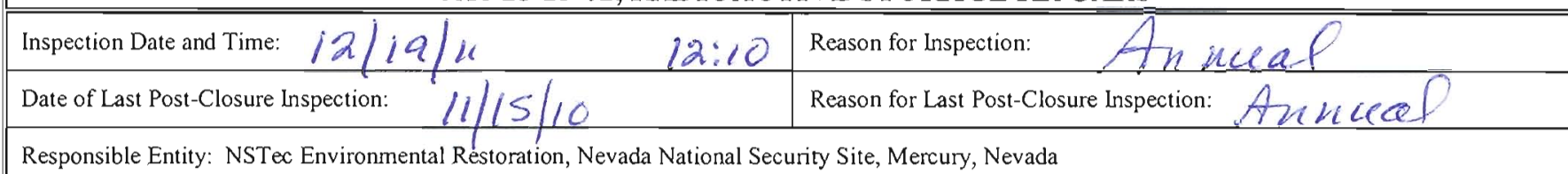

Responsible Entity: NSTec Environmental Restoration, Nevada National Security Site, Mercury, Nevada

Responsible Facility Owner: Thomas A. Thiele, Project Manager, Industrial Sites, Environmental Restoration Project

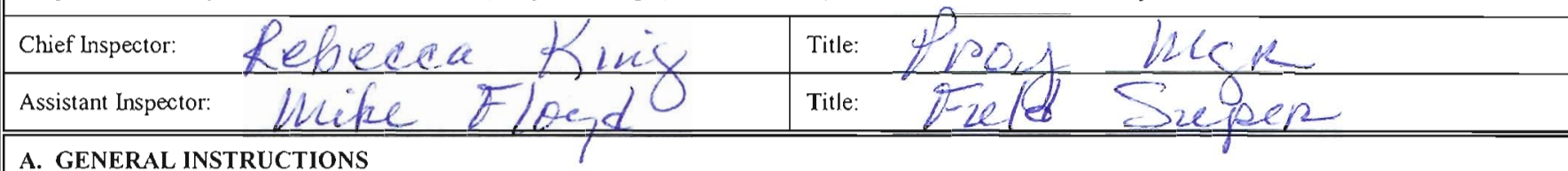

A. GENERAL INSTRUCTIONS

- Complete all checklist items.

- If a SHADED BOX is checked, provide detailed information and/or appropriate references to other documents that have the information.

- All documentation must be legible and clear.

\begin{tabular}{|l|l|l|l} 
B. PREPARATION (To be completed prior to site visit) & YES & NO & EXPLANATION (required if shaded box is checked)
\end{tabular}

1. Has the Post-Closure Plan been reviewed?

2. Have the previous inspection reports been reviewed?

3. Were anomalies or trends detected on previous inspections?

4. Were maintenance or repair activities performed since the last inspection?

\section{SITE INSPECTION PREPARATION}

Assemble the following, as needed, to conduct inspections:

- Radio, pager, etc.

- Previous letter report, inspection checklists, repair records, and as-built plans

- Camera, digital storage drive, extra batteries, and other miscellaneous support equipment

\section{SITE INSPECTION}

- The site inspection is a walking inspection of the entire perimeter to visually inspect all features specifically described in this checklist and observe whether there is an indication that the use restriction may have been compromised. Entry into the fenced area is not required for the inspection. The checklist should be completed during the site inspection.

- If a shaded box is checked, add detailed comments to document the results of the site inspection. Information provided should be of sufficient detail to enable reconstruction of observations regarding field conditions. The completed checklist is part of the field record of the inspection.

- Field notes taken to assist in completion of this checklist will become part of the inspection record. No form is specified for field notes, and additional field notes are not required if the checklist and associated attachments adequately describe site conditions.

1. Site Markers:

a. Is there damage to the fence or fence posts?

b. Have any sign posts been damaged or their anchoring weakened?

c. Are all use restriction signs legible?

d. Are any of the 18 use restriction signs damaged or missing?

e. How many damaged or missing signs need to be replaced?

f. Are any use restriction signs down?

g. How many down signs need to be re-hung?

h. Do any Radioactive Material Area signs need to be replaced or re-hung?

\begin{tabular}{|c|c|l||} 
YES & NO & EXPLANATION (required if shaded box is checked) \\
\hline & $\checkmark$ & \\
\hline & $\checkmark$ & \\
\hline & & \\
\hline & & \\
\hline & & \\
\hline & 1 & 1 \\
\hline & & \\
\hline
\end{tabular}

Page 1 of 2 


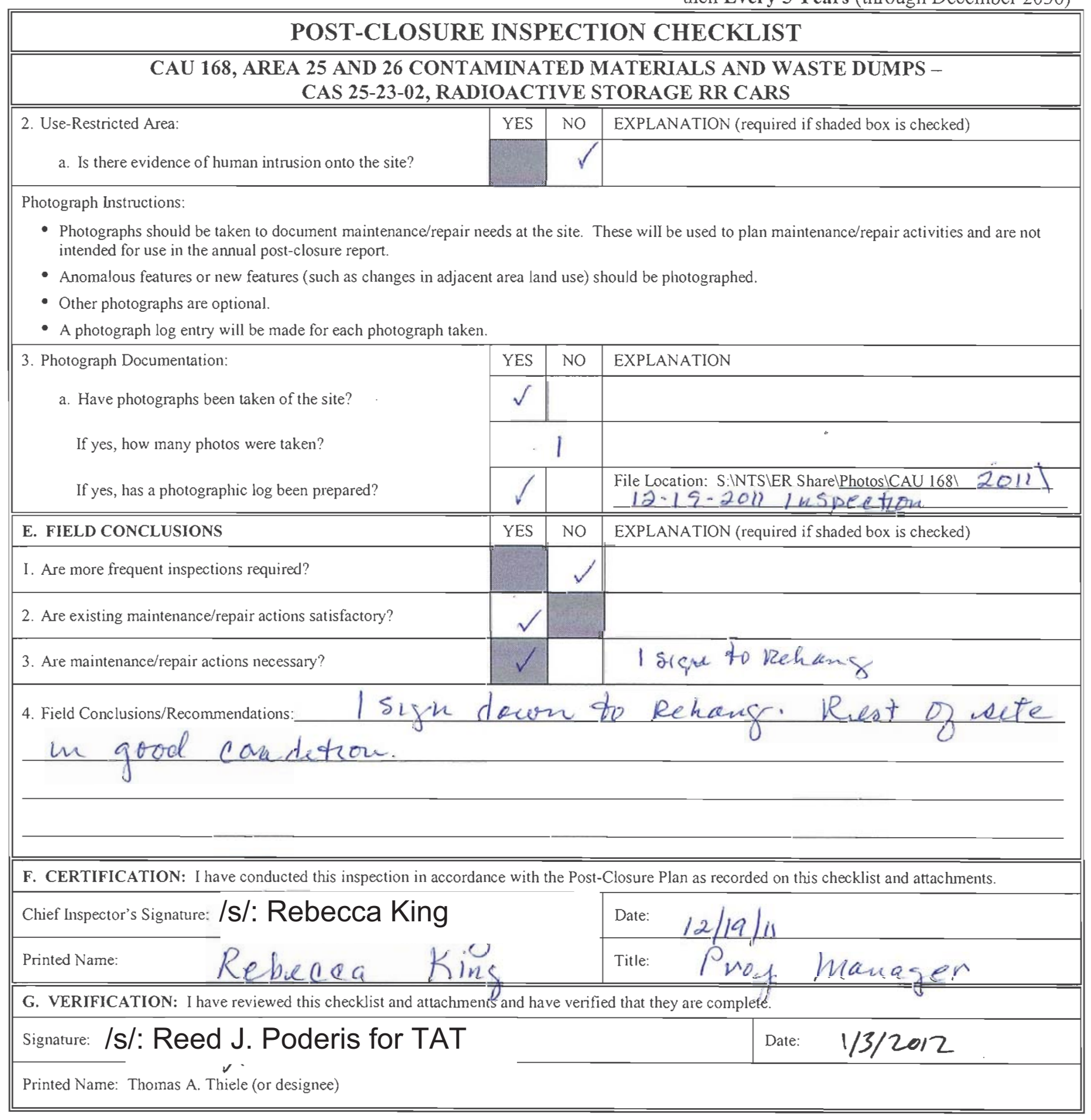




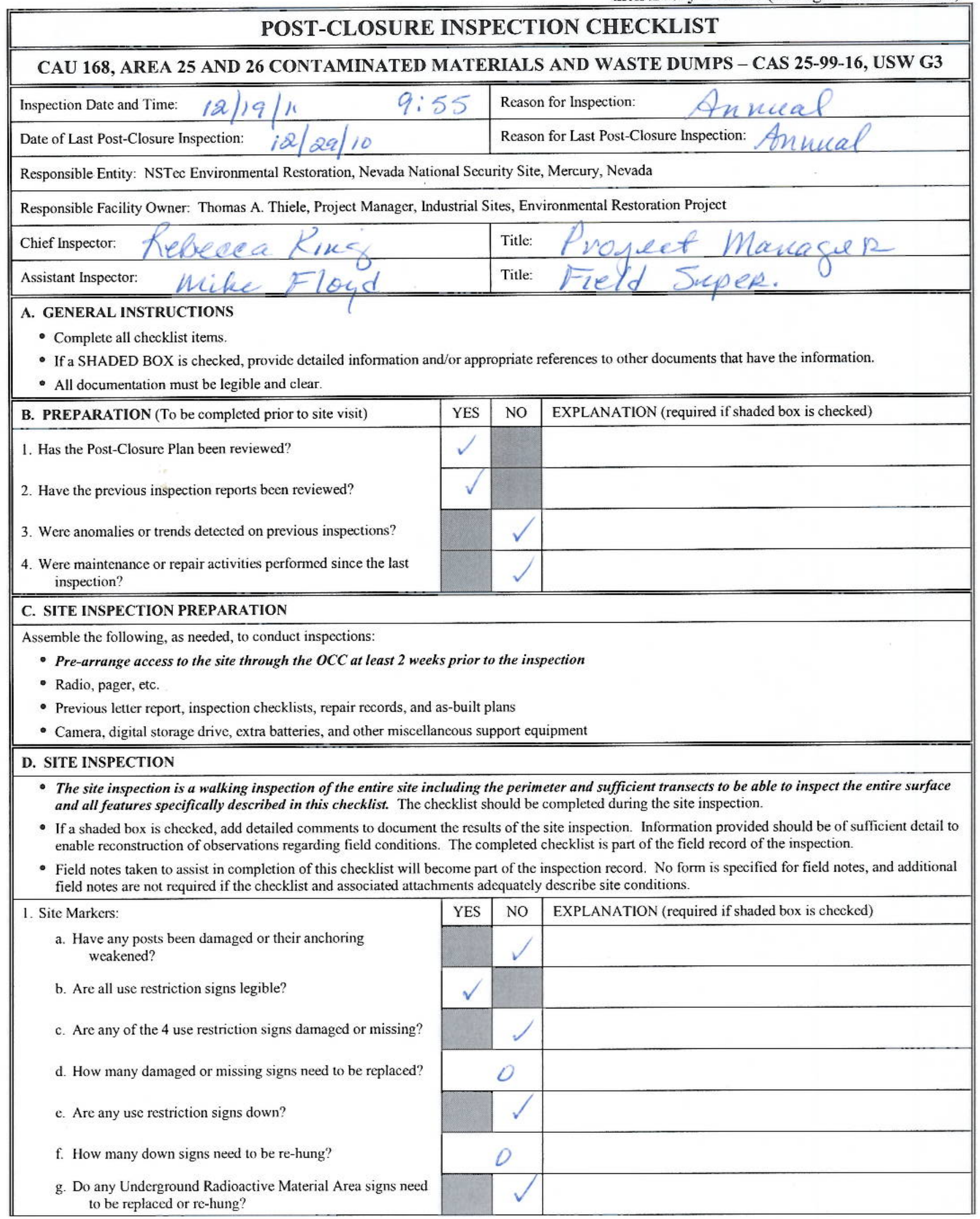




\section{POST-CLOSURE INSPECTION CHECKLIST}

\section{CAU 168, AREA 25 AND 26 CONTAMINATED MATERIALS AND WASTE DUMPS - CAS 25-99-16, USW G3}

\begin{tabular}{l|l|l|l}
\hline 2. Use-Restricted Area: & YES & NO & EXPLANATION (required if shaded box is checked) \\
\cline { 2 - 4 }
\end{tabular}

a. Is there evidence of human intrusion onto the site?

Photograph Instructions:

- Photographs should be taken to document maintenance/repair needs at the site. These will be used to plan maintenance/repair activities and are not intended for use in the annual post-closure report.

- Anomalous features or new features (such as changes in adjacent area land use) should be photographed.

- Other photographs are optional.

- A photograph log entry will be made for each photograph taken.

3. Photograph Documentation:

a. Have photographs been taken of the site?

If yes, how many photos were taken?

If yes, has a photographic log been prepared?

\begin{tabular}{|c|c|c|}
\hline YES & NO & EXPLANATION \\
\hline$\sqrt{ }$ & & \\
\hline & 2 & \\
\hline$\sqrt{ }$ & & $\begin{array}{l}\text { File Location: S:INTSIER SharelPhotosiCAU } 168 \backslash 20111 \\
12-19-2011 \text { Inspection }\end{array}$ \\
\hline
\end{tabular}

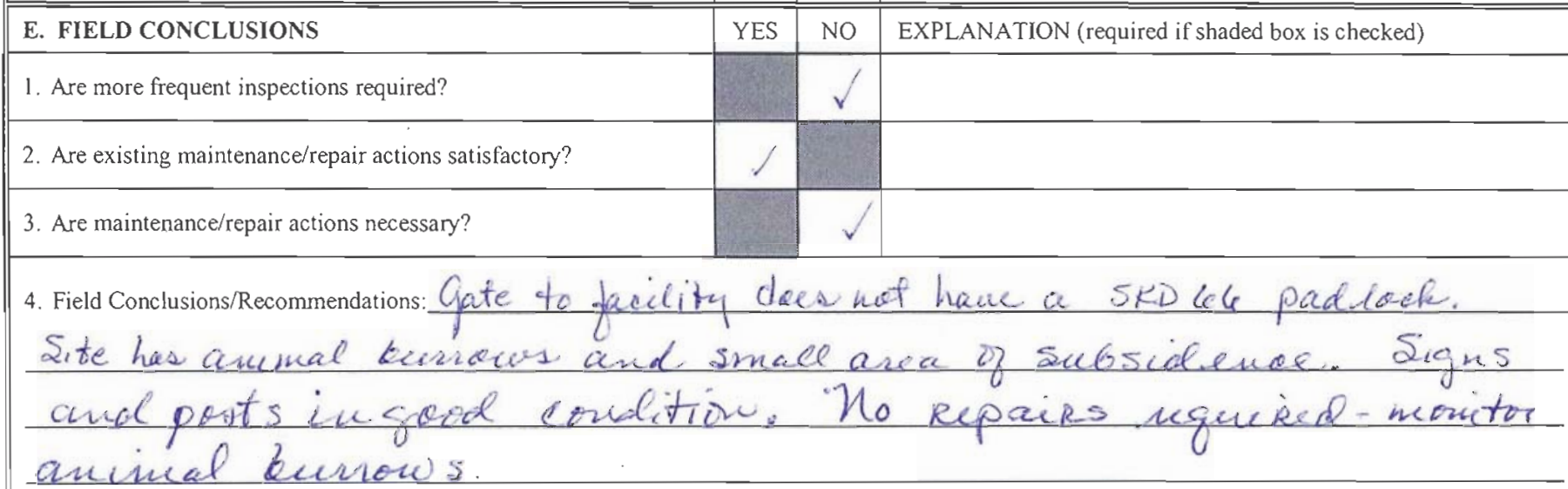

F. CERTIFICATION: I have conducted this inspection in accordance with the Post-Closure Plan as recorded on this checklist and attachunents.

Chief Inspector's Signature: /s/: Rebecca King Printed Name: Rebecea Krns

G. VERIFICATION: $\backslash$ have reviewed this checklist and attachments and have verified that they are complete.

Signature: /s/: Reed J. Poderis for TAT

Date: $1 / 3 / 12$

Printed Name: Thomas A. Thiele (or designee) 
CAU 204: STORAGE BUNKERS 
THIS PAGE INTENTIONALLY LEFT BLANK 


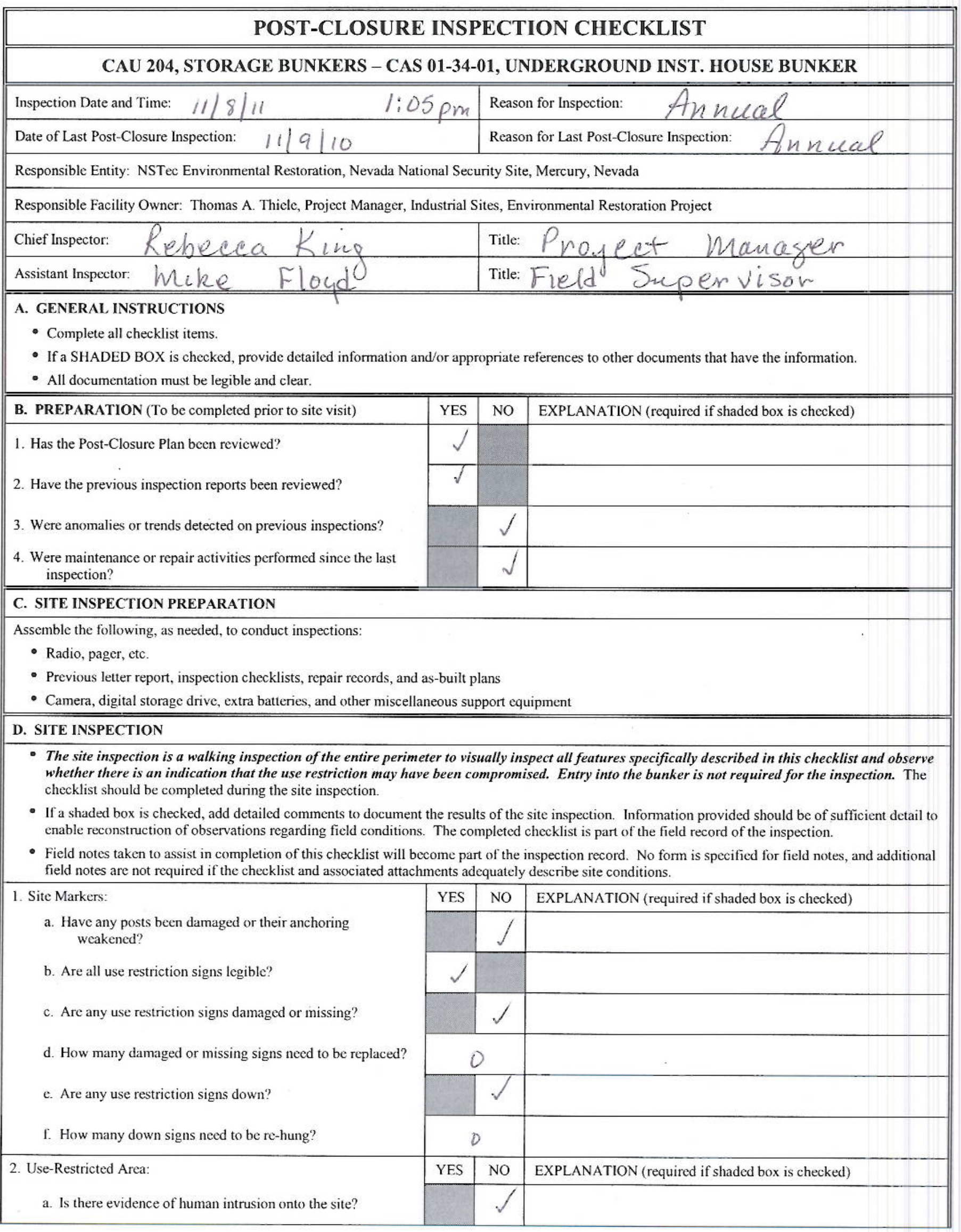


Inspection Requirement: Annual

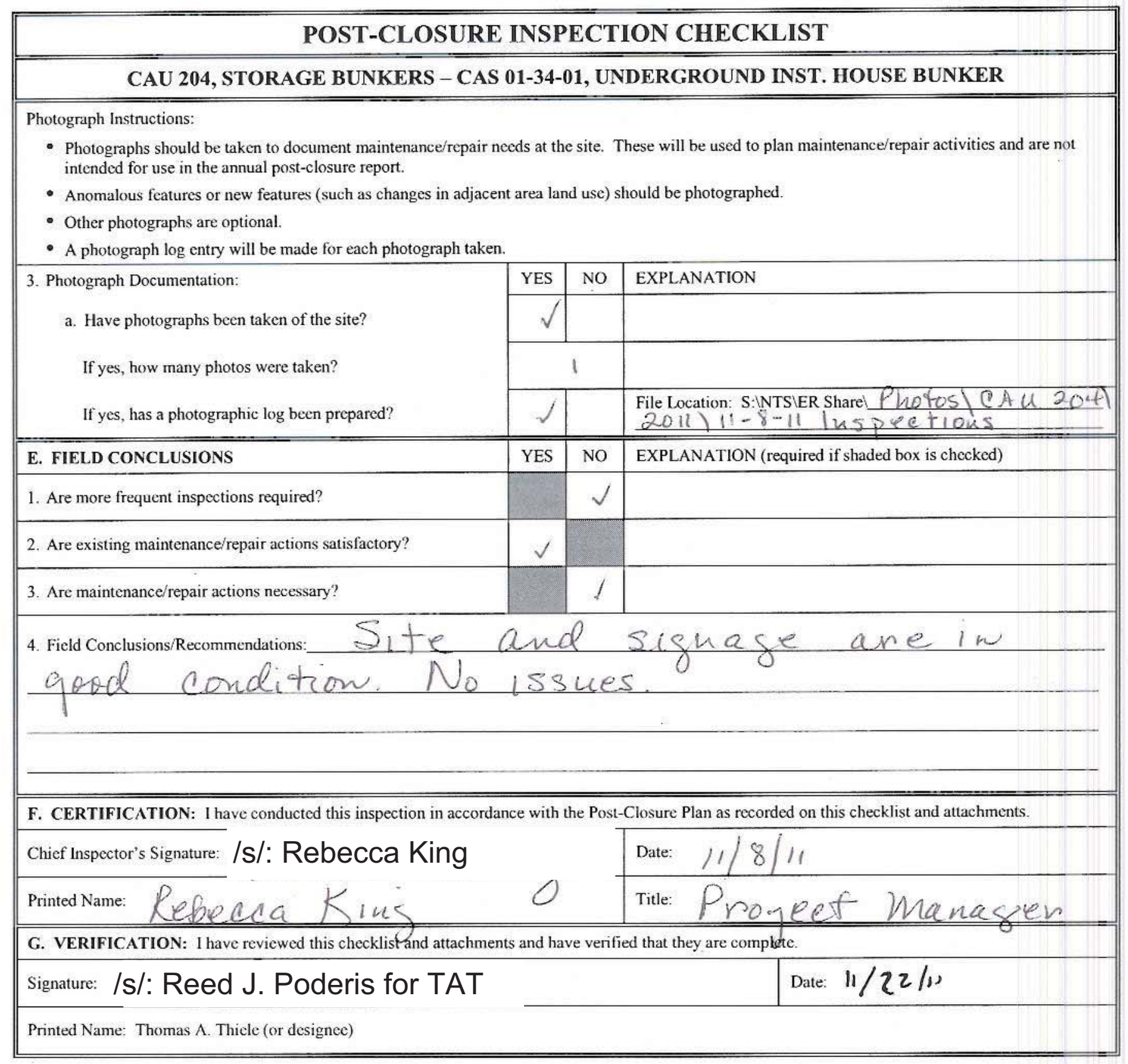




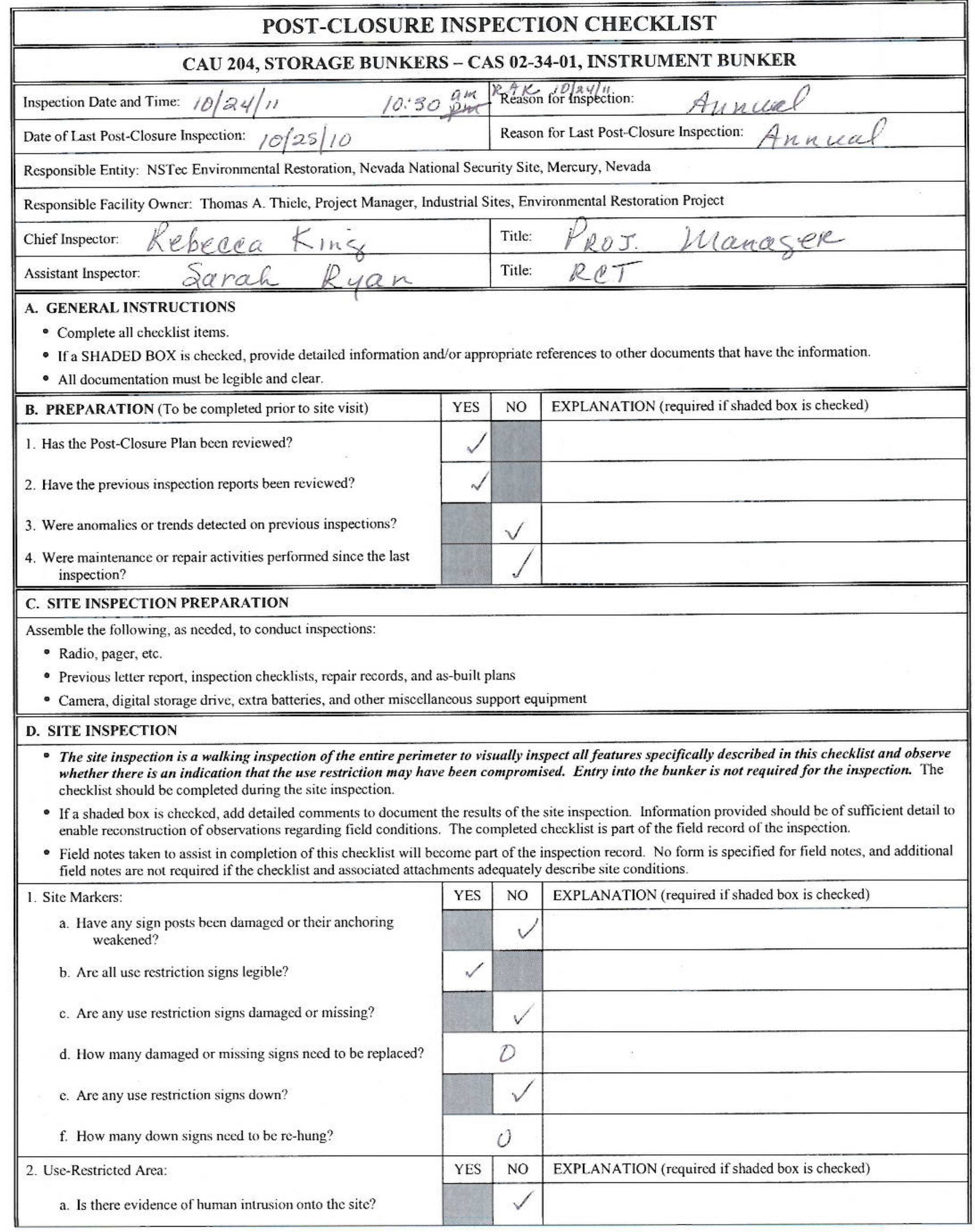




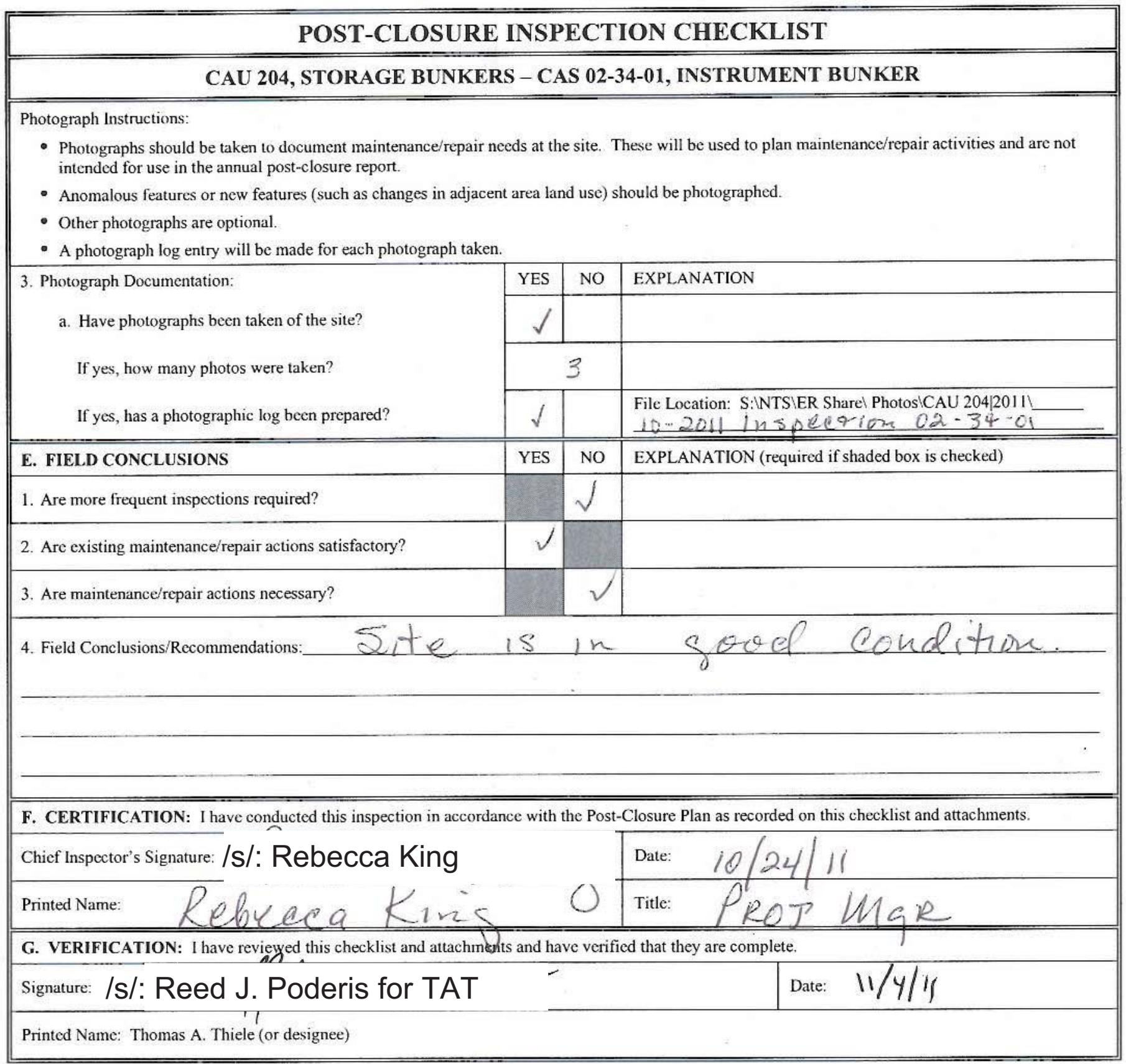


Inspection Requirement: Annual

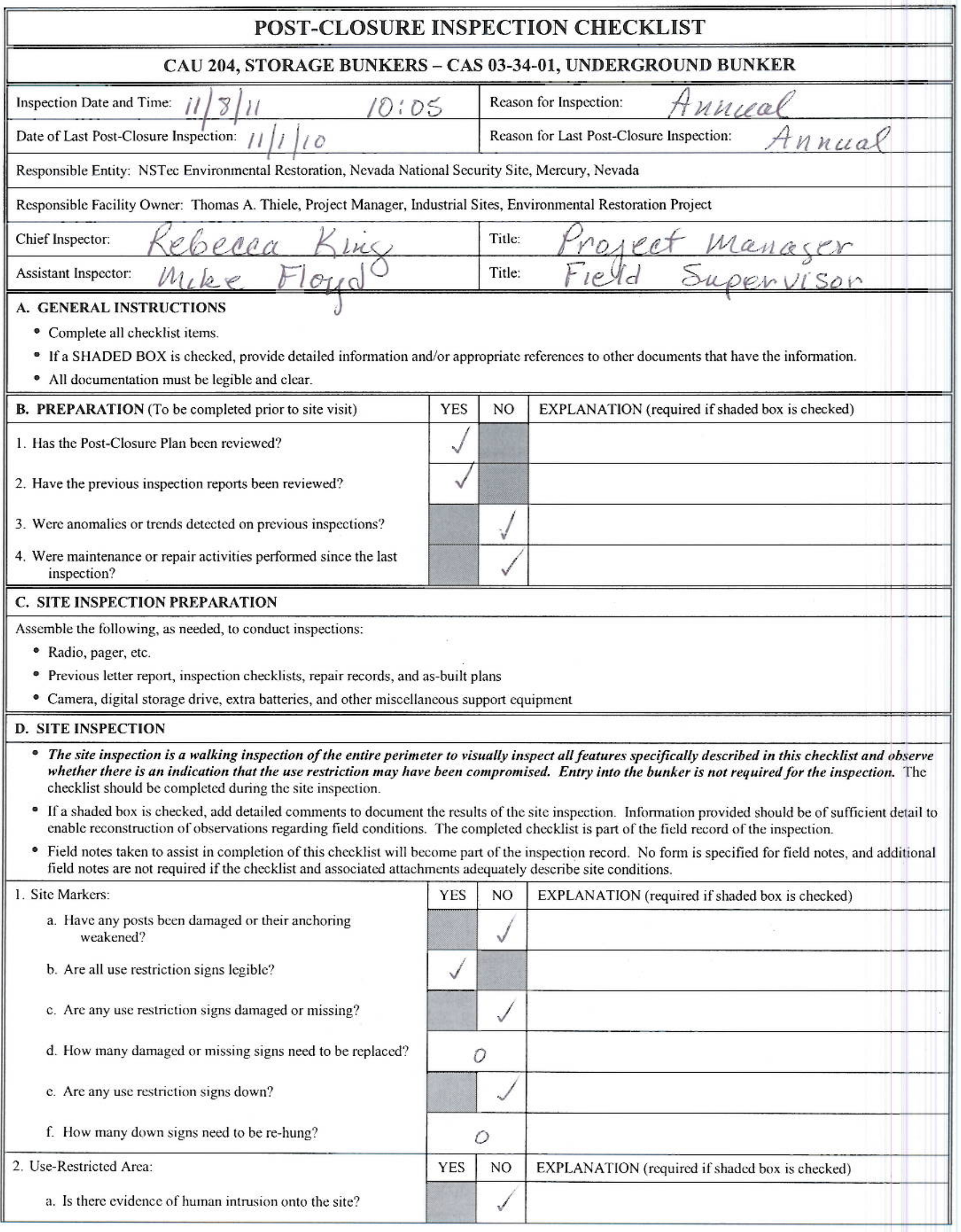




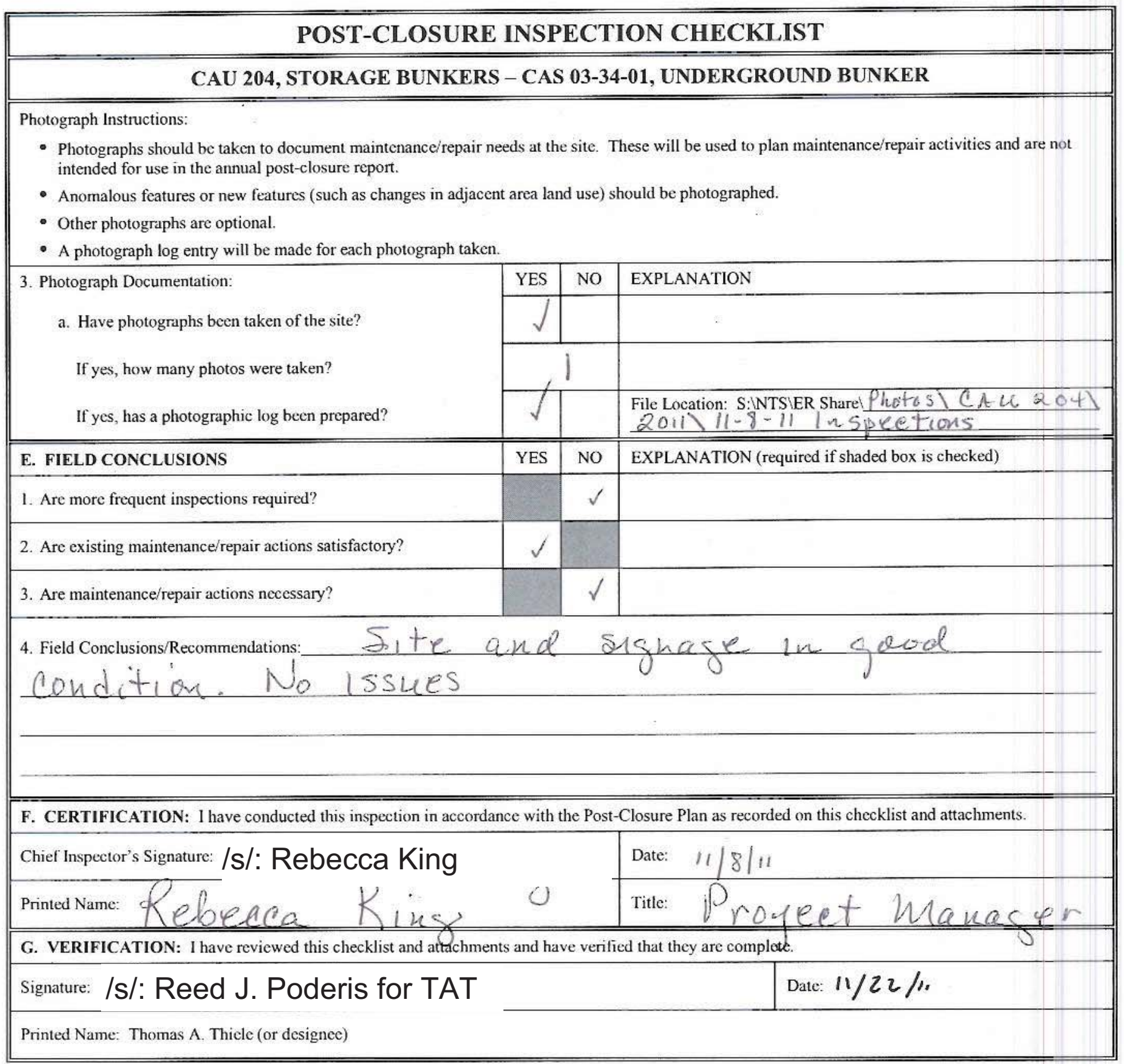




\section{POST-CLOSURE INSPECTION CHECKLIST}

\section{CAU 204, STORAGE BUNKERS - CAS 05-18-02, CHEMICAL EXPLOSIVES STORAGE}

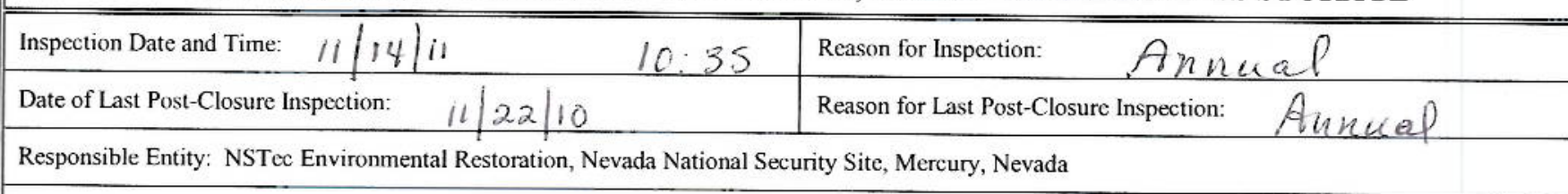

Responsible Facility Owner: Thomas A. Thiele, Project Manager, Industrial Sites, Environmental Restoration Project

\begin{tabular}{|c|c|c|}
\hline chief Inspector: Rebeaca King & Title: Propeet & Wa hacer \\
\hline Assistant Inspector: hake Rlocid & Title: Fletd Se & wison jer \\
\hline
\end{tabular}

A. GENERAL INSTRUCTIONS

- Complete all checklist items.

- If a SHADED BOX is checked, provide detailed information and/or appropriate references to other documents that have the information.

- All documentation must be legible and clear.

\begin{tabular}{||l|c|c|c||}
\hline \hline B. PREPARATION (To be completed prior to site visit) & YES & NO & EXPLANATION (required if shaded box is checked) \\
\hline 1. Has the Post-Closure Plan been reviewed? & & & \\
\cline { 2 - 5 } 2. Have the previous inspection reports been reviewed? & & & \\
\cline { 2 - 5 } $\begin{array}{l}\text { 3. Were anomalies or trends detected on previous inspections? } \\
\text { inspection? }\end{array}$ & & $\sqrt{ }$ & \\
\hline \hline
\end{tabular}

\section{SITE INSPECTION PREPARATION}

Assemble the following, as needed, to conduct inspections:

- Radio, pager, etc.

- Previous letter report, inspection checklists, repair records, and as-built plans

- Camera, digital storage drive, extra batteries, and other miscellaneous support equipment

\section{SITE INSPECTION}

- The site inspection is a walking inspection of the entire perimeter to visually inspect all features specifically described in this checklist and observe whether there is an indication that the use restriction may have been compromised. Entry into the fenced area is not required for the inspection. The checklist should be completed during the site inspection,

- If a shaded box is checked, add detailed comments to document the results of the site inspection. Information provided should be of sufficient detail to enable reconstruction of observations regarding field conditions. The completed checklist is part of the field record of the inspection.

- Field notes taken to assist in completion of this checklist will become part of the inspection record. No fonm is specified for field notes, and additional field notes are not required if the checklist and associated atlachments adequately describe site conditions.

1. Site Markers:

a. Is there damage to the fence?

b. Have any posts been damaged or their anchoring weakened?

c. Are all use restriction signs legible?

d. Are any of the 13 use restriction signs damaged or missing?

e. How many damaged or missing signs need to be replaced?

f. Are any use restriction signs down?

g. How many down signs need to be re-hung?

2. Use-Restricted Area:

a. Is there evidence of human intrusion onto the site?

\begin{tabular}{|r|r|l||}
\hline YES & NO & EXPLANATION (required if shaded box is checked) \\
\hline & $\checkmark$ & \\
\hline$\checkmark$ & & \\
\hline & $\checkmark$ & \\
\hline & & \\
\hline & $\checkmark$ & \\
\hline & & \\
\hline YES & NO & EXPLANATION (required if shaded box is checked) \\
\hline & $\checkmark$ & \\
\hline
\end{tabular}


Inspection Requirement: Annual

\section{POST-CLOSURE INSPECTION CHECKLIST}

\section{CAU 204, STORAGE BUNKERS - CAS 05-18-02, CHEMICAL EXPLOSIVES STORAGE}

Photograph Instructions:

- Photographs should be taken to document maintenance/repair needs at the site. These will be used to plan maintenance/repair activities and are not intended for use in the annual post-closure report.

- Anomalous features or new features (such as changes in adjacent area land use) should be photographed.

- Other photographs are optional.

- A photograph log entry will be made for each photograph taken.

3. Photograph Documentation:

a. Have photographs been taken of the site?

If yes, how many photos were taken?

If yes, has a photographic log been prepared?

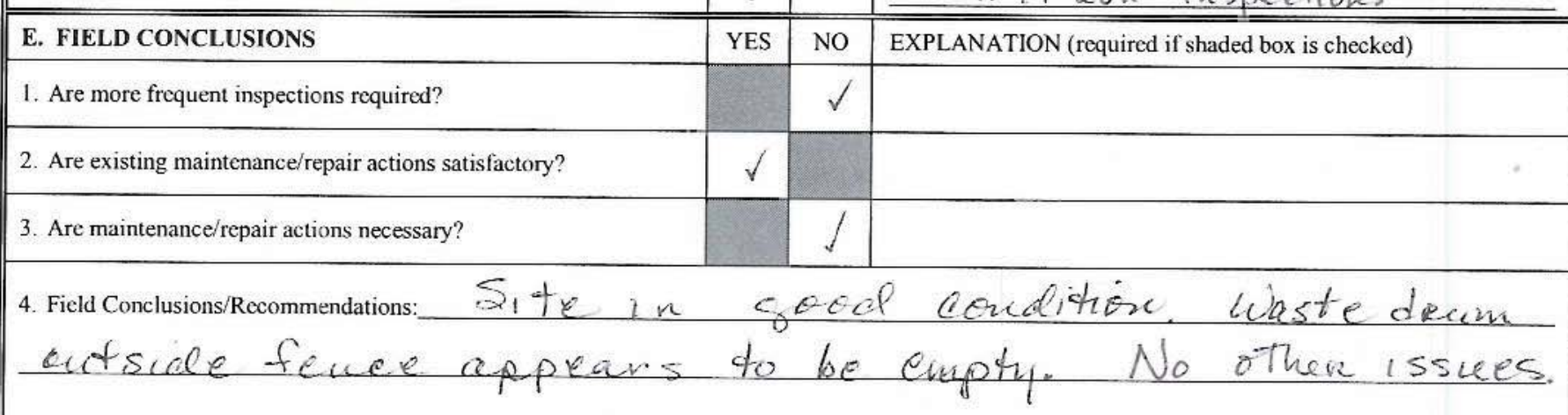

F. CERTIFICATION: I have conducted this inspection in accordance with the Post-Closure Plan as recorded on this checklist and attachments.

Chief Inspector's Signature:, /s/: Rebecca King

Printed Name: Rebeces Kinc

G. VERIFIGATION: I have reviewed this checklist and attachments and have verified that they are complete.

Signature: /s/: Reed J. Poderis for TAT 1

Date: $1 / 14 / \|$
Title: $/ 120$ ofe of 112 ance $R$
Date: $11 / 28 / 1$

Printed Name: Thomas A. Thiele (or designee) 
Inspection Requirement: Annual

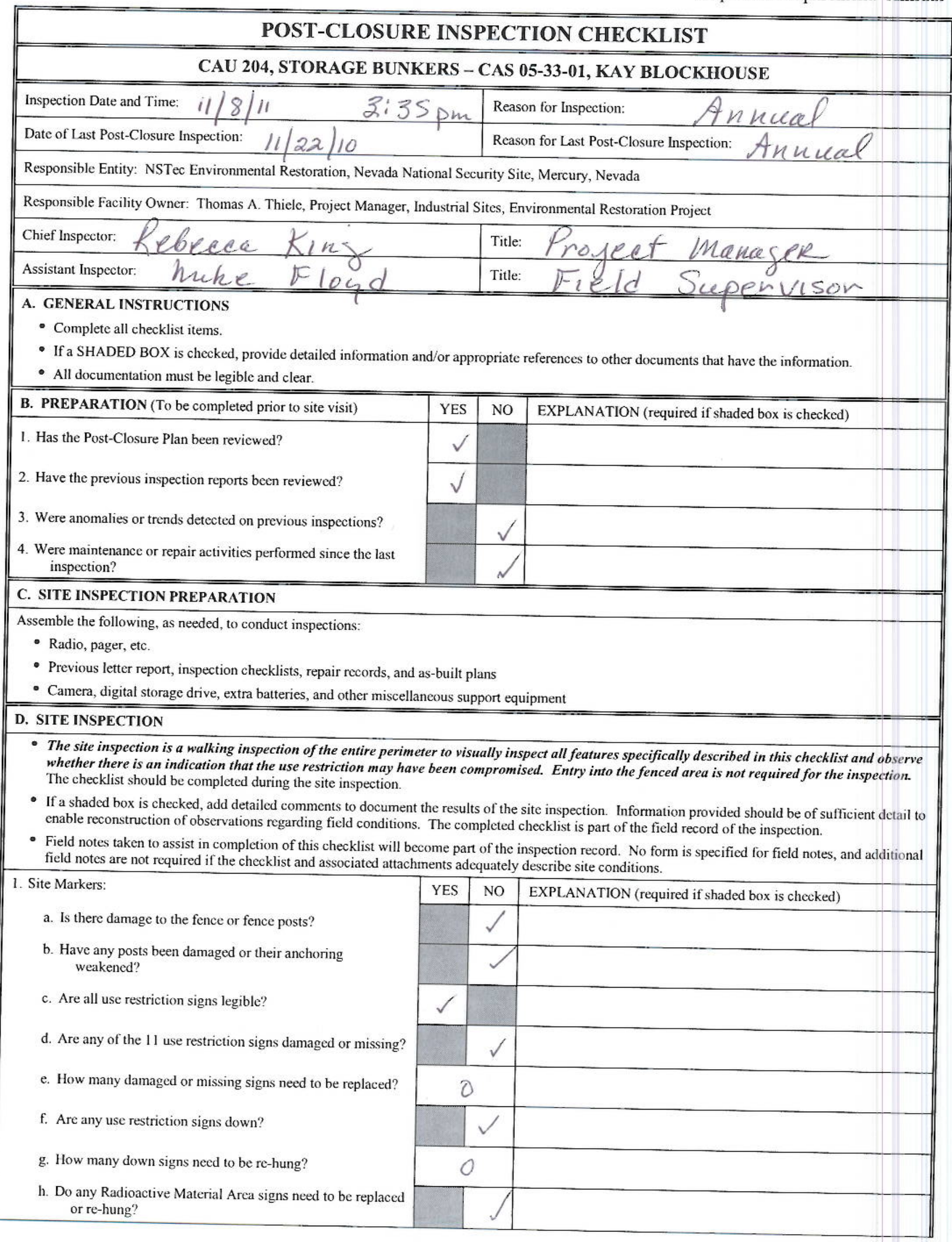


Inspection Requirement: Annual

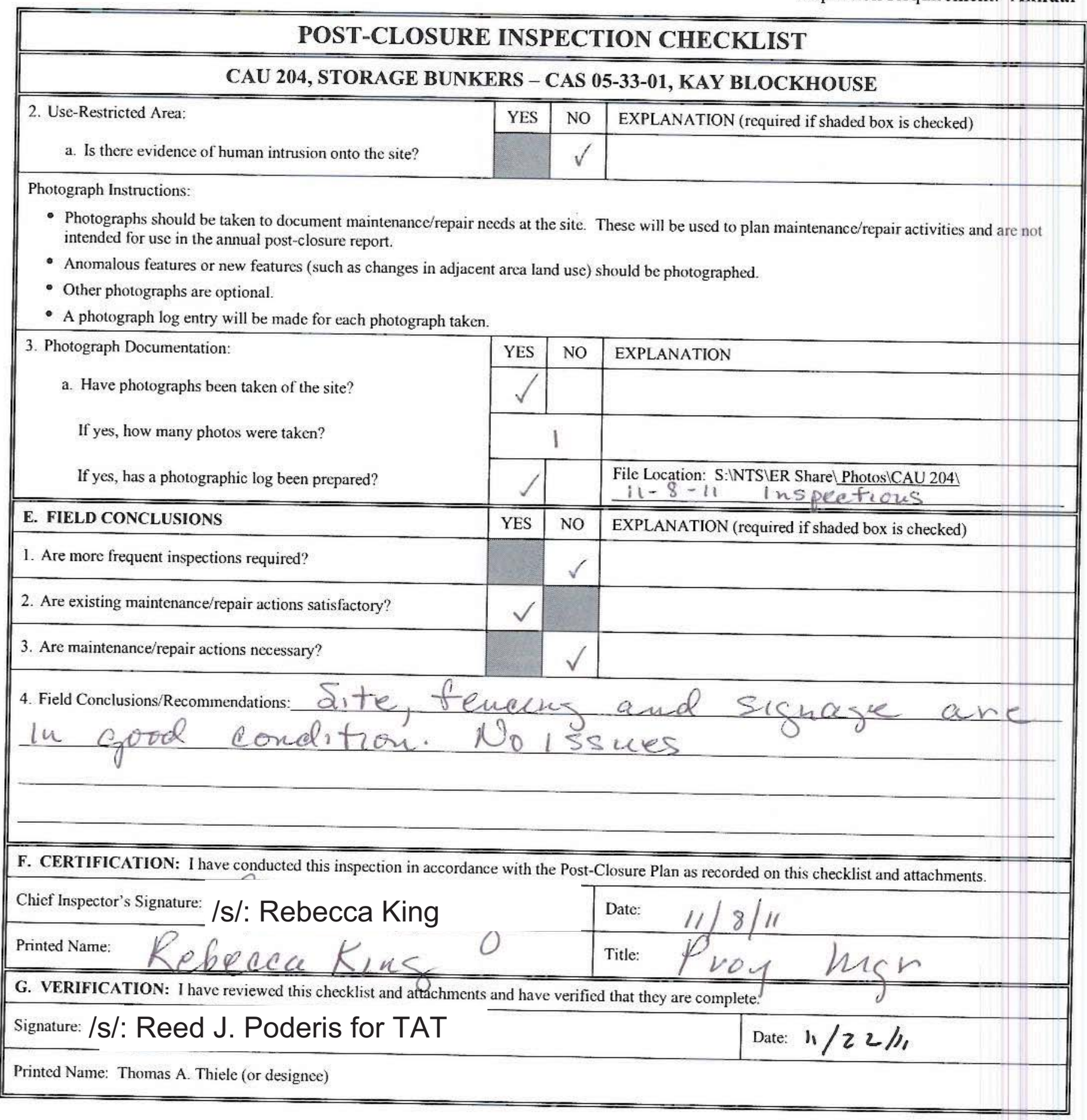


CAU 254: AREA 25 R-MAD DECONTAMINATION FACILITY 
THIS PAGE INTENTIONALLY LEFT BLANK 


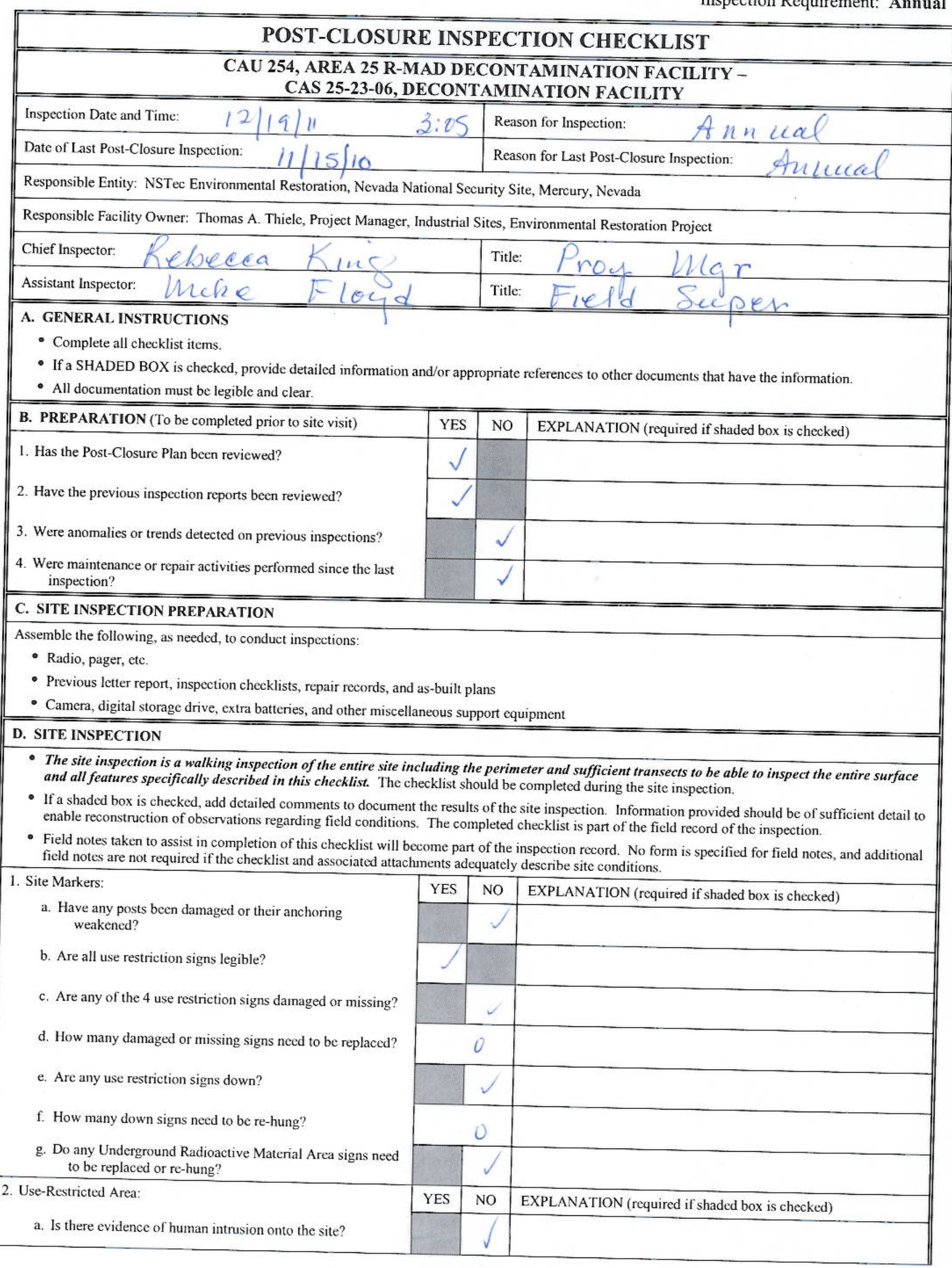




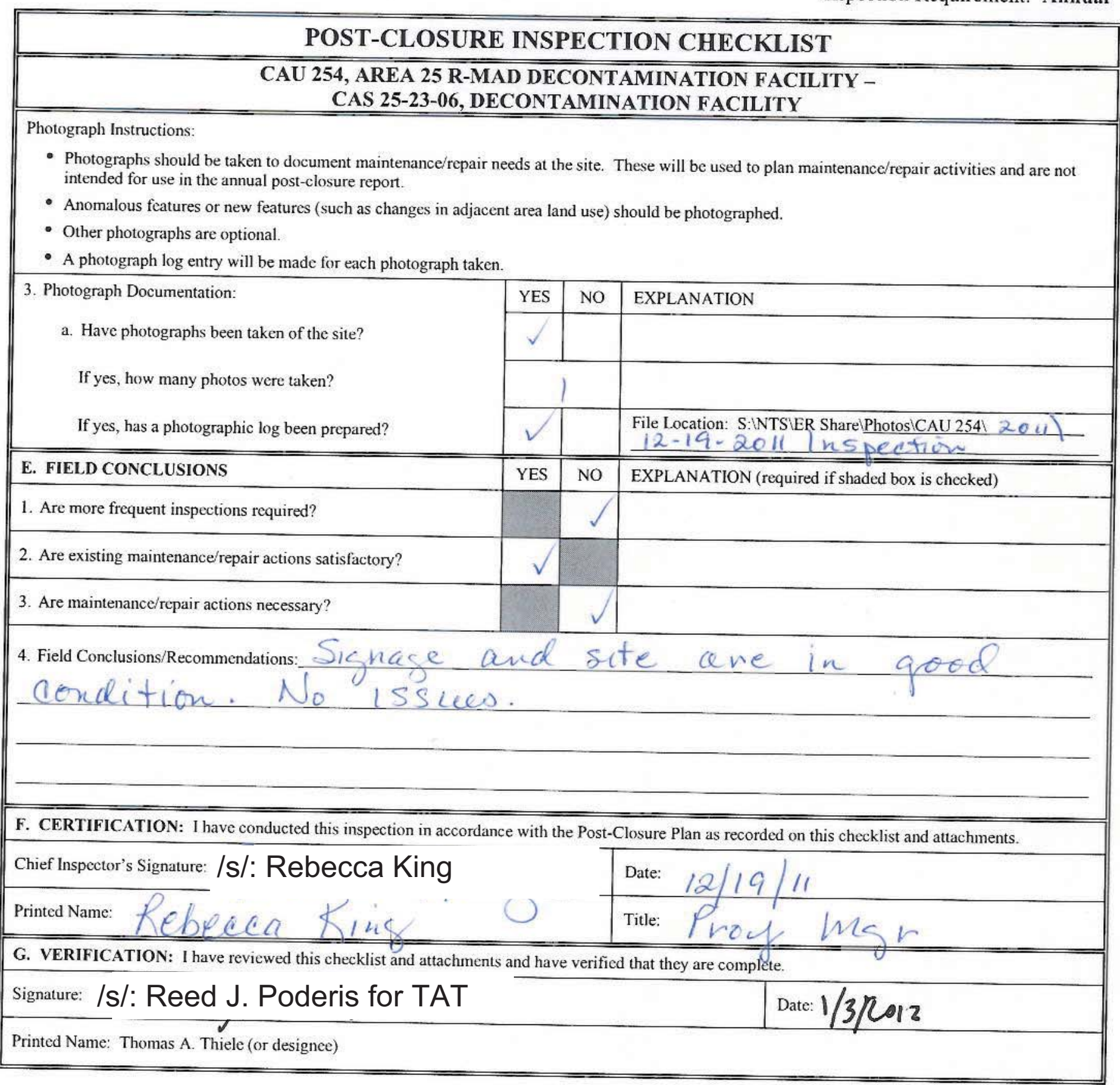


CAU 261: AREA 25 TEST CELL A LEACHFIELD SYSTEM 
THIS PAGE INTENTIONALLY LEFT BLANK 


\section{POST-CLOSURE INSPECTION CHECKLIST}

\section{CAU 261, AREA 25 TEST CELL A LEACHFIELD SYSTEM - CAS 25-05-01, LEACHFIELD}

\begin{tabular}{|c|c|c|}
\hline Inspection Date and Time: $1 / 2 / 20$ & $10: 15$ & Reason for Inspection: \\
\hline Date of Last Post-Closure Inspection: & $11 / 15 / 10$ & Reason for Last Post-Closure Inspection: \\
\hline
\end{tabular}

Responsible Facility Owner: Thomas A. Thiele, Project Manager, Industrial Sites, Environmental Restoration Project

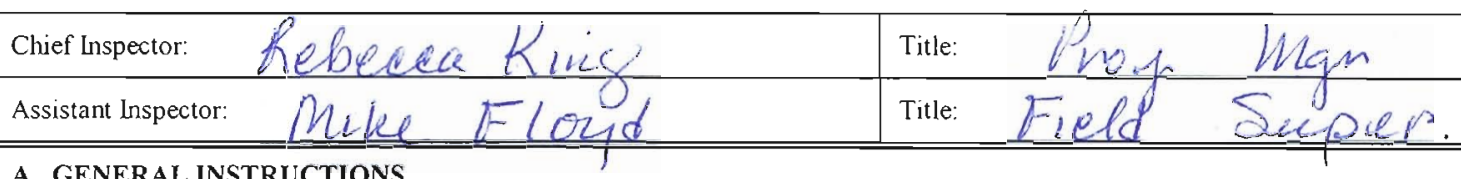

- Complete all checklist items.

- If a SHADED BOX is checked, provide detailed information and/or appropriate references to other documents that have the information.

- All documentation must be legible and clear

\begin{tabular}{|l|l|l|l|}
\hline \hline B. PREPARATION (To be completed prior to site visit) & YES & NO & EXPLANATION (required if shaded box is checked) \\
\hline $\begin{array}{l}\text { 1. Has the Post-Closure Plan been reviewed? } \\
\text { 2. Have the previous inspection reports been reviewed? }\end{array}$ & & & \\
\cline { 2 - 5 } $\begin{array}{l}\text { 3. Were anomalies or trends detected on previous inspections? } \\
\text { 4. Were maintenance or repair activities performed since the last } \\
\text { inspection? }\end{array}$ & & & \\
\hline \hline
\end{tabular}

\section{SITE INSPECTION PREPARATION}

Assemble the following, as needed, to conduct inspections:

- Radio, pager, etc.

- Previous letter report, inspection checklists, repair records, and as-built plans

- Camera, digital storage drive, extra batteries, and other miscellaneous support equipment

\section{SITE INSPECTION}

- The site inspection is a walking inspection of the entire perimeter to visually inspect all features specifically described in this checklist and observe whether there is an indication that the use restriction may have been compromised. Entry into the fenced area is not required for the inspection. The checklist should be completed during the site inspection.

- If a shaded box is checked, add detailed comments to document the results of the site inspection. Information provided should be of sufficient detail to enable reconstruction of observations regarding field conditions. The completed checklist is part of the field record of the inspection.

- Field notes taken to assist in completion of this checklist will become part of the inspection record. No form is specified for field notes, and additional field notes are not required if the checklist and associated attachments adequately describe site conditions.

1. Site Markers:

a. Is there damage to the fence or fence posts?

b. Have any sign posts been damaged or their anchoring weakened?

c. Are all use restriction signs legible?

d. Are any of the 4 use restriction signs damaged or missing?

e. How many damaged or missing signs need to be replaced?

f. Are any use restriction signs down?

g. How many down signs need to be re-hung?

h. Do any Underground Radioactive Material Area signs need to be replaced or re-hung?

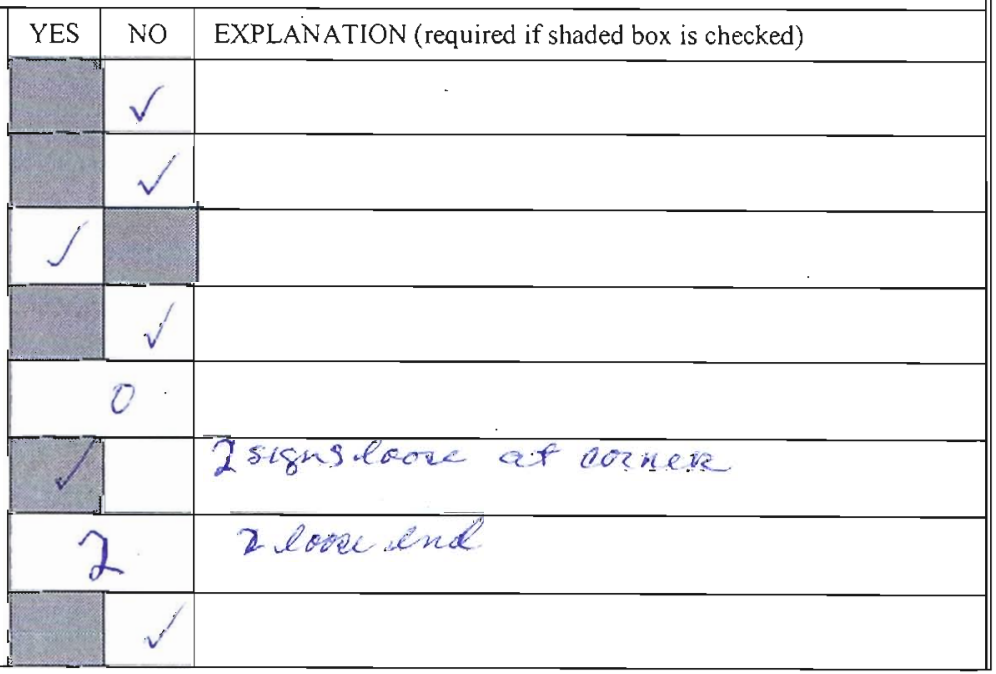


POST-CLOSURE INSPECTION CHECKLIST

CAU 261, AREA 25 TEST CELL A LEACHFIELD SYSTEM - CAS 25-05-01, LEACHFIELD

2. Use-Restricted Area:

a. Is there evidence of human intrusion onto the site?

\begin{tabular}{|c|c|c|} 
YES & NO & EXPLANATION (required if shaded box is checked) \\
\hline & $\sqrt{ }$ \\
\hline
\end{tabular}

Photograph Instructions:

- Photographs should be taken to document maintenance/repair needs at the site. These will be used to plan maintenance/repair activities and are not intended for use in the annual post-closure report.

- Anomalous features or new features (such as changes in adjacent area land use) should be photographed.

- Other photographs are optional.

- A photograph log entry will be made for each photograph taken.

3. Photograph Documentation:

a. Have photographs been taken of the site?

If yes, how many photos were taken?

If yes, has a photographic log been prepared?

\begin{tabular}{|l|l|l|l|}
\hline \hline E. FIELD CONCLUSIONS & YES & NO & EXPLANATION (required if shaded box is checked) \\
\hline 1. Are more frequent inspections required? & & & \\
\hline 2. Are existing maintenance/repair actions satisfactory? & & & \\
\hline 3. Are maintenance/repair actions necessary? & Re fasteu sighs & & Ren \\
\hline
\end{tabular}

4. Field Conclusions/Recommendations: 2 LR sigus with loose corkere to

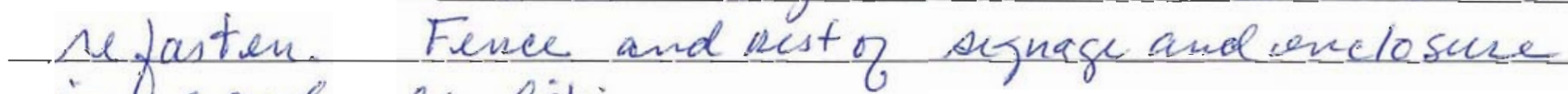
in good condition.

F. CERTIFICATION: I have conducted this inspection in accordance with the Post-Closure Plan as recorded on this checklist and attachments. Chief Inspector's Signature: /s/: Rebecca King Printed Name: Rebpeca $R$ ins $\begin{array}{ll}\text { Date: } & 12 / 20 / \text { II } \\ \text { Title: Prop of hanaser }\end{array}$

G. VERIFICATION: 1 have reviewed this checklist and attachments and have verified that they are complete. Signature: /s/: Reed J. Poderis for TAT Date: $1 / 3 / 2012$

Printed Name: Thomas A. Thiele (or designee) 
CAU 262: AREA 25 SEPTIC SYSTEMS AND UDP 
THIS PAGE INTENTIONALLY LEFT BLANK 


\section{POST-CLOSURE INSPECTION CHECKLIST}

\section{CAU 262, AREA 25 SEPTIC SYSTEMS AND UDP - CAS 25-02-06, UNDERGROUND STORAGE TANK}

Inspection Date and Time: $12 / 20 / 1$

Date of Last Post-Closure Inspection:

I/ $/ 5 / 10$

Responsible Entity: NSTec Environmental Restoration, Nevada National Security Site, Mercury, Nevada

Responsible Facility Owner: Thomas A. Thiele, Project Manager, Industrial Sites, Environmental Restoration Project

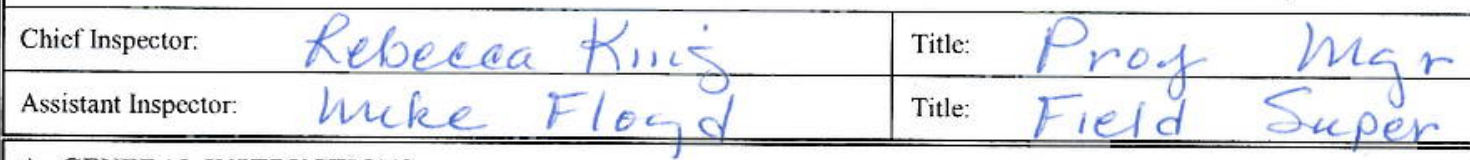

\section{A. GENERAL INSTRUCTIONS}

- Complete all checklist items.

- If a SHADED BOX is checked, provide detailed information and/or appropriate references to other documents that have the information.

- All documentation must be legible and clear.

\begin{tabular}{|c|c|c|c|}
\hline B. PREPARATION (To be completed prior to site visit) & YES & NO & EXPLANATION (required if shaded box is checked) \\
\hline 1. Has the Post-Closure Plan been reviewed? & & & \\
\hline 2. Have the previous inspection reports been reviewed? & & & \\
\hline 3. Were anomalies or trends detected on previous inspections? & & & \\
\hline $\begin{array}{l}\text { 4. Were maintenance or repair activities performed since the last } \\
\text { inspection? }\end{array}$ & & & Slgu nuaintenance \\
\hline
\end{tabular}

\section{SITE INSPECTION PREPARATION}

Assemble the following, as needed, to conduct inspections:

- Radio, pager, etc.

- Previous letter report, inspection checklists, repair records, and as-built plans

- Camera, digital storage drive, extra batteries, and other miscellaneous support equipment

\section{SITE INSPECTION}

- The site inspection is a walking inspection of the entire site including the perimeter and sufficient transects to be able to inspect the entire surface and all features specifically described in this checklist. The checklist should be completed during the site inspection.

- If a shaded box is checked, add detailed comments to document the results of the site inspection. Information provided should be of sufficient detail to enable reconstruction of observations regarding field conditions. The completed checklist is part of the field record of the inspection.

- Field notes taken to assist in completion of this checklist will become part of the inspection record. No form is specified for field notes, and additional field notes are not required if the checklist and associated attachments adequately describe site conditions.

1. Site Markers:

a. Have any posts been damaged or their anchoring weakened?

b. Are all use restriction signs legible?

c. Is either of the 2 use restriction signs damaged or missing?

d. How many damaged or missing signs need to be replaced?

e. Are any use restriction signs down?

f. How many down signs need to be re-hung?

2. Use-Restricted Area:

a. Is there evidence of human intrusion onto the site?

\begin{tabular}{|l|l|l||}
\hline YES & NO & EXPLANATION (required if shaded box is checked) \\
\hline & & \\
\hline & & \\
\hline & & \\
\hline & 6 & \\
\hline & & \\
\hline & 0 & \\
\hline YES & NO & EXPLANATION (required if shaded box is checked) \\
\hline & & \\
\hline
\end{tabular}




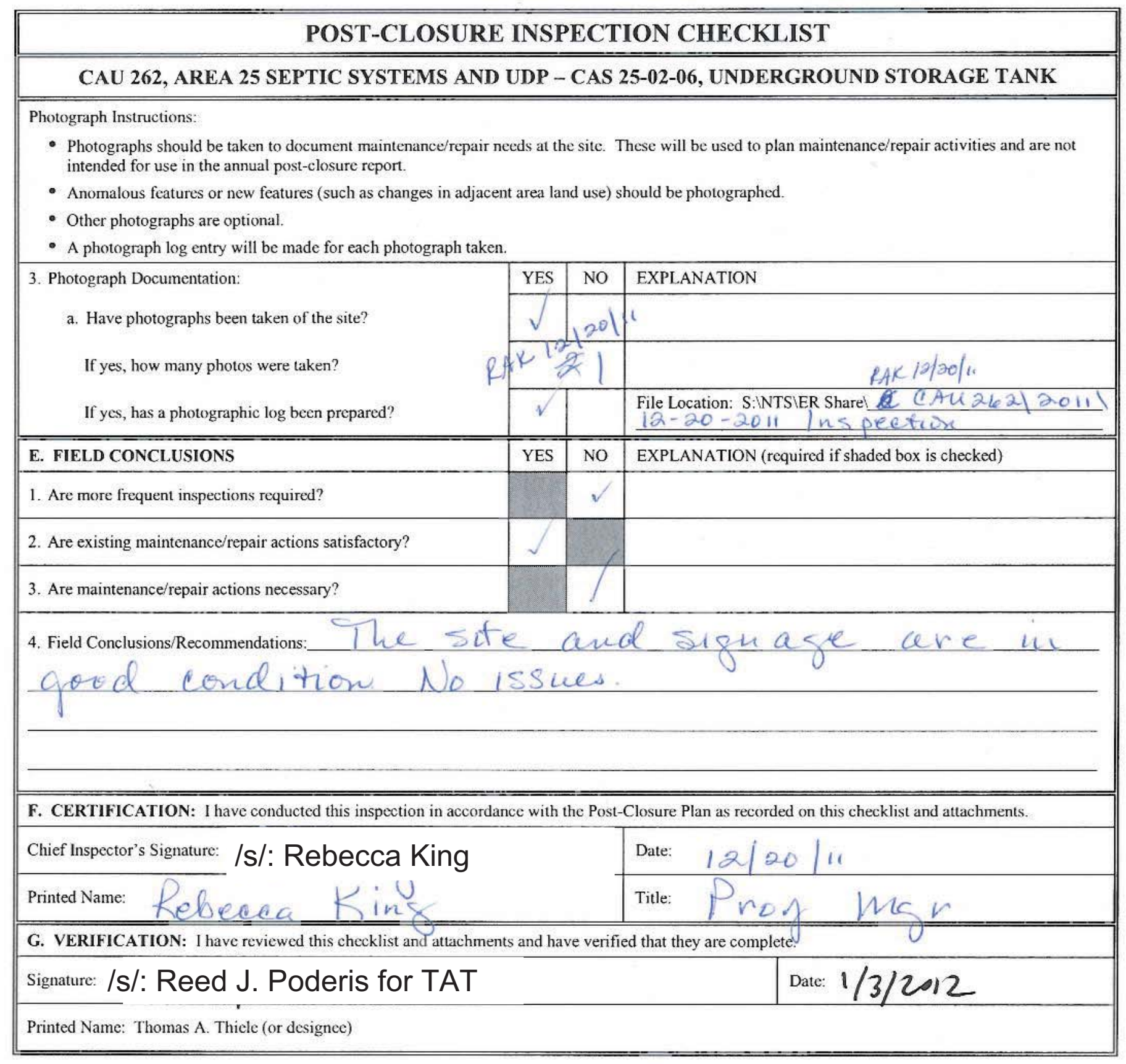




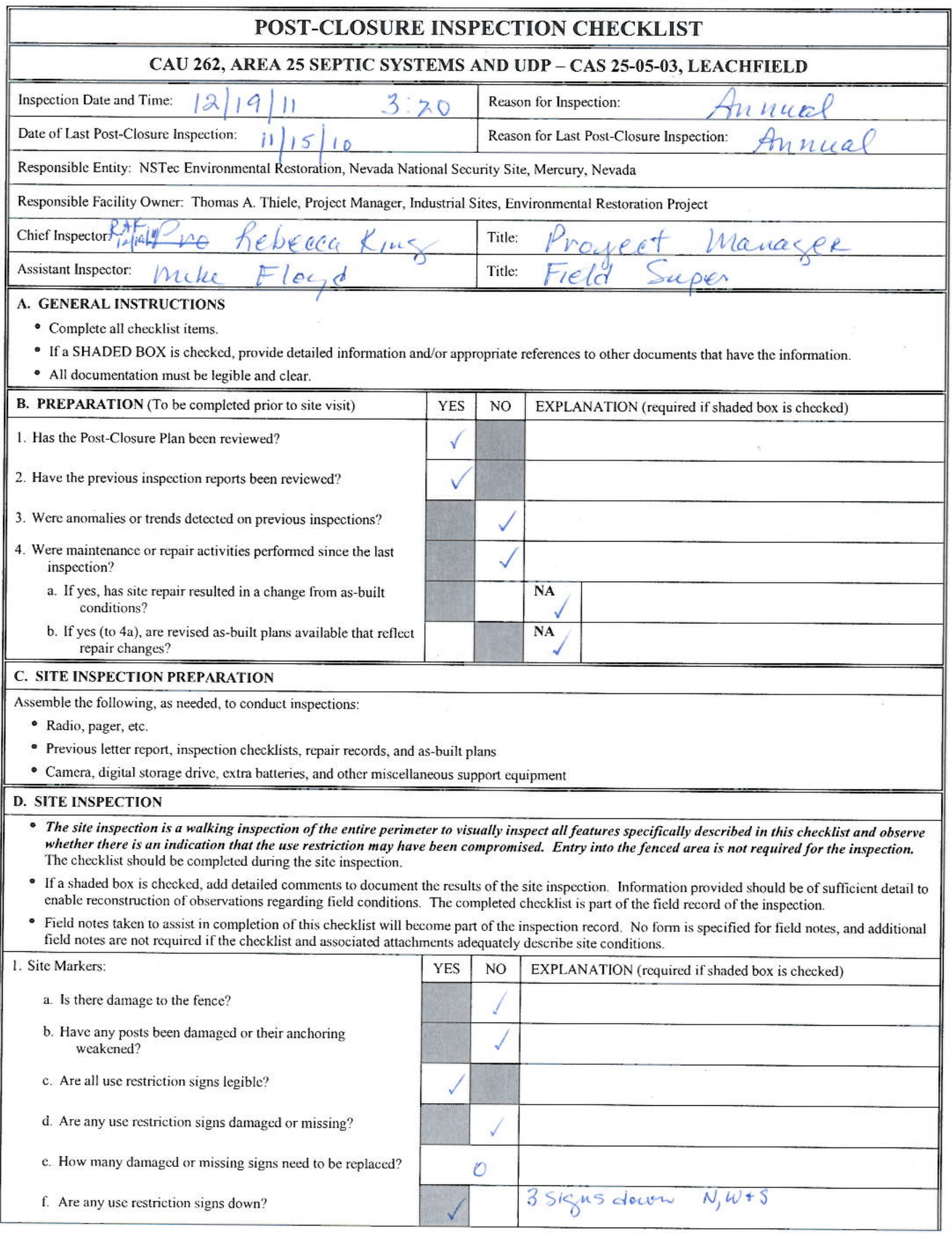




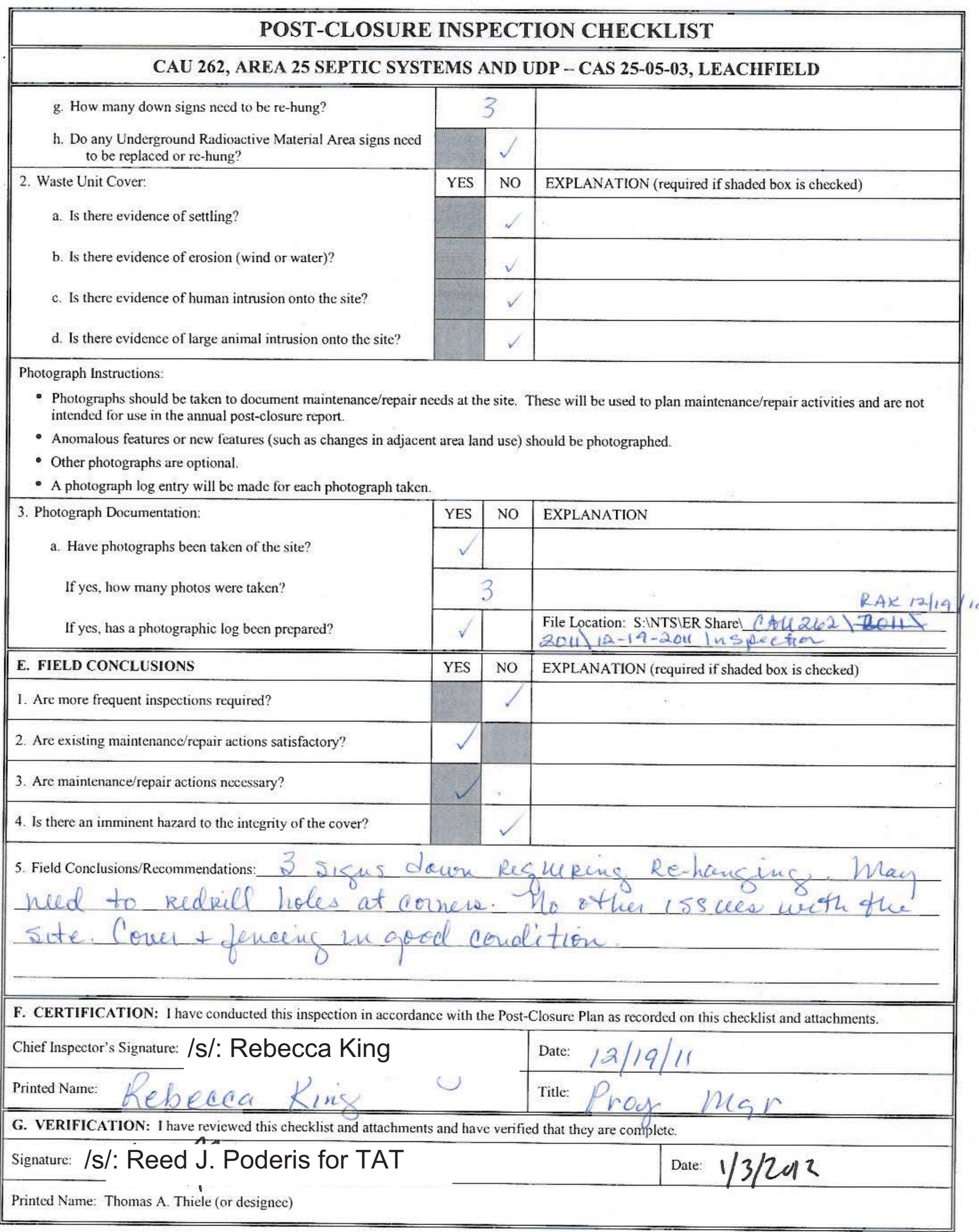




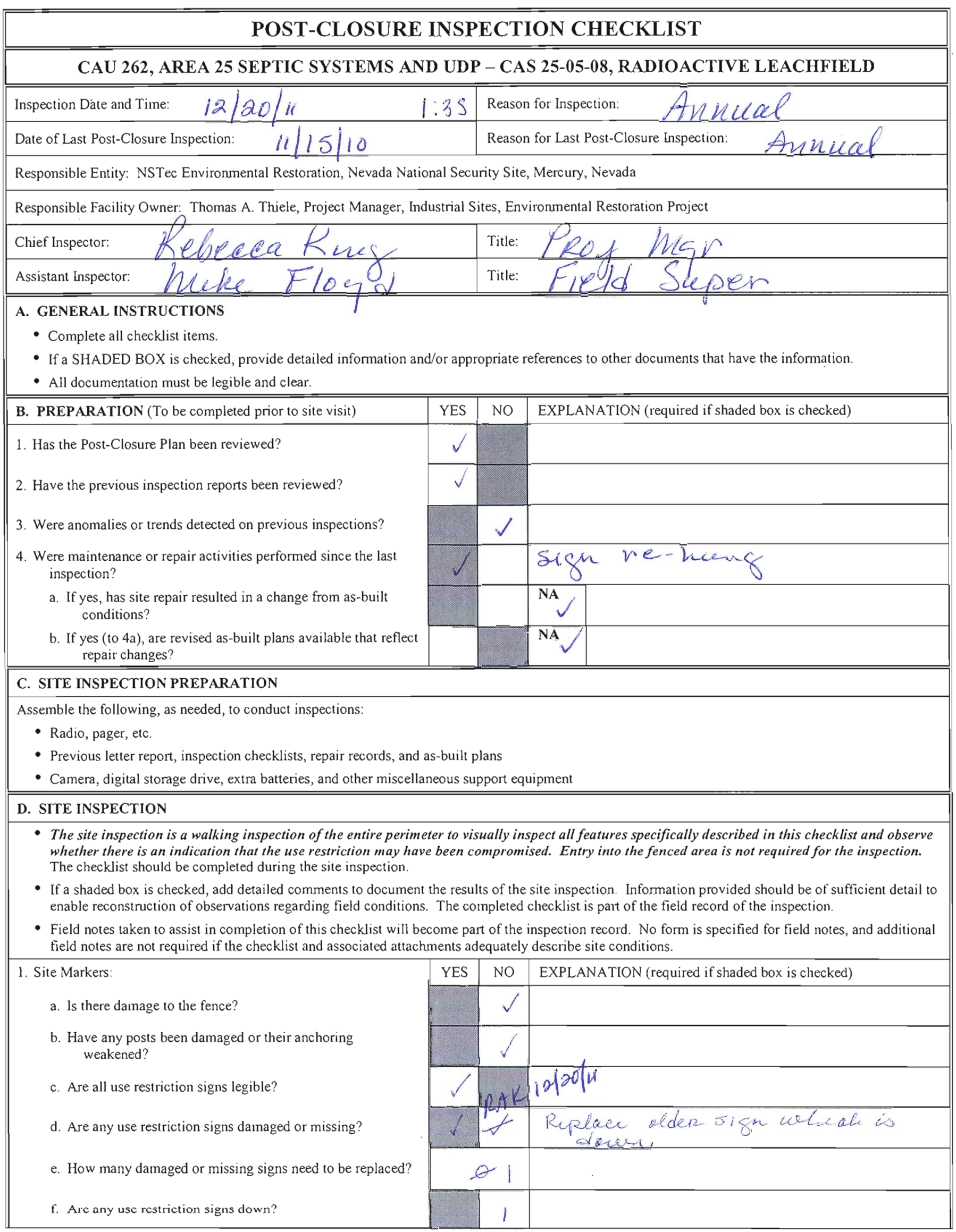




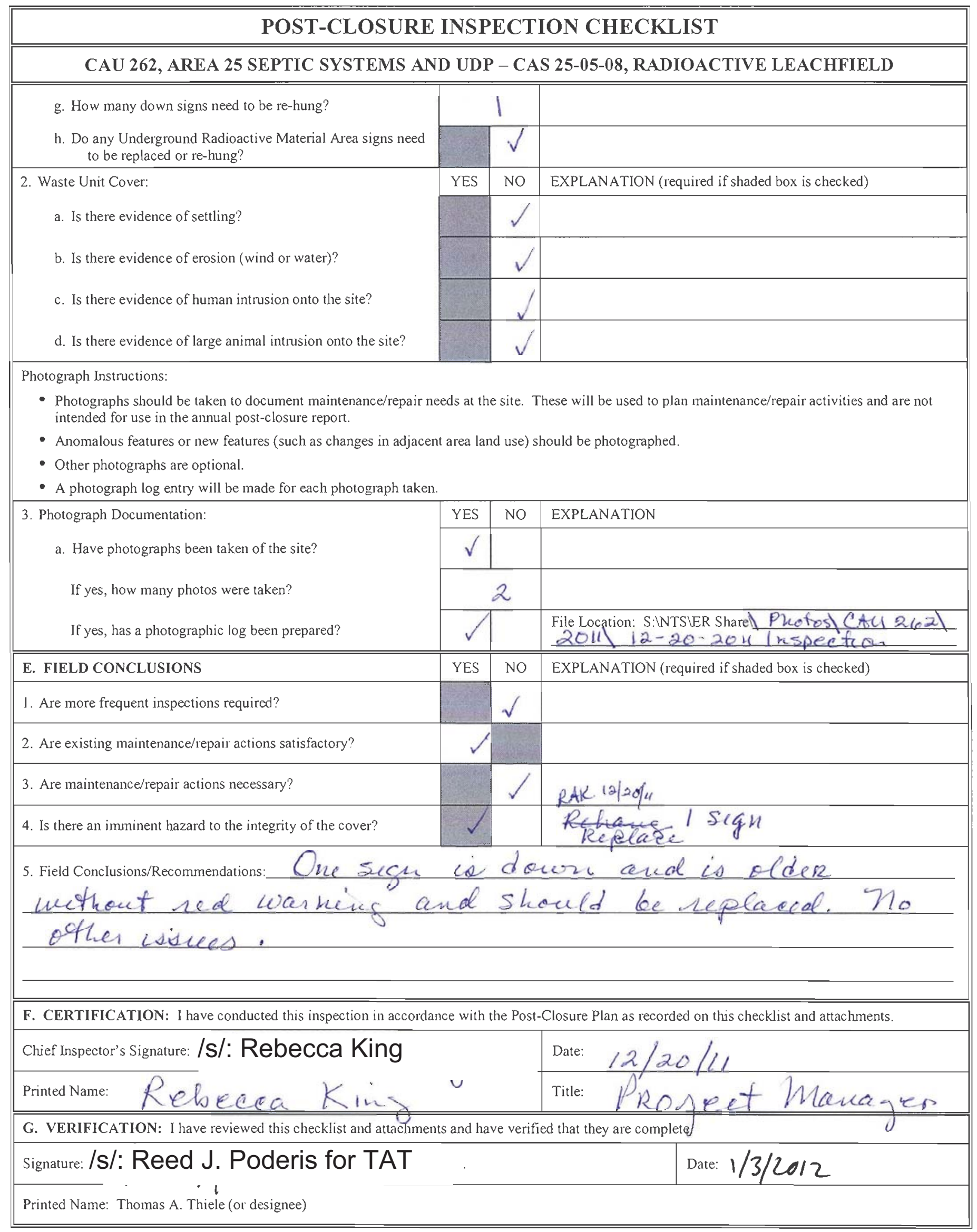


CAU 309: AREA 12 MUCKPILES 
THIS PAGE INTENTIONALLY LEFT BLANK 


\begin{tabular}{|c|c|c|c|}
\hline \multicolumn{4}{|c|}{ POST-CLOSURE INSPECTION CHECKLIST } \\
\hline \multicolumn{4}{|c|}{$\begin{array}{l}\text { CAU 309, AREA } 12 \text { MUCKPILES - CAS 12-06-09, MUCKPILE, } \\
\text { CAS 12-08-02, CONTAMINATED WASTE DUMP (CWD), AND CAS 12-28-01, I, J, AND K-TUNNEL DEBRIS }\end{array}$} \\
\hline \multicolumn{2}{|c|}{ Inspection Date and Time: $10 / 19 / 11 \quad 3: 00 \mathrm{pm}$} & \multicolumn{2}{|c|}{ Reason for Inspection: $A$ in nual } \\
\hline \multicolumn{2}{|c|}{ Date of Last Post-Closure Inspection: $10 / 11 / 10$} & \multicolumn{2}{|c|}{ Reason for Last Post-Closure Inspection: Ahncial } \\
\hline \multicolumn{4}{|c|}{ Responsible Entity: NSTec Environmental Restoration, Nevada National Security Site, Mercury, Nevada } \\
\hline \multicolumn{4}{|c|}{ Responsible Facility Owner: Thomas A. Thiele, Project Manager, Industrial Sites, Environmental Restoration Project } \\
\hline \multicolumn{2}{|c|}{ Chief Inspector: Kebuecia Kins } & Title: & hanasen \\
\hline \multicolumn{2}{|l|}{ Assistant Inspector: Sarach ku,ak } & Titl & $R C^{N}$ \\
\hline \multicolumn{4}{|c|}{$\begin{array}{l}\text { A. GENERAL INSTRUCTIONS } \\
\text { - Complete all checklist items. } \\
\text { - If a SHADED BOX is checked, provide detailed information and/or appropriate references to other documents that have the information. } \\
\text { - All documentation must be legible and clear. }\end{array}$} \\
\hline B. PREPARATION (To be completed prior to site visit) & YES & NO & EXPLANATION (required if shaded box is checked) \\
\hline \multirow{4}{*}{$\begin{array}{l}\text { 1. Has the Post-Closure Plan been reviewed? } \\
\text { 2. Have the previous inspection reports been reviewed? } \\
\text { 3. Were anomalies or trends detected on previous inspections? } \\
\text { 4. Were maintenance or repair activities performed since the last } \\
\text { inspection? }\end{array}$} & & & \\
\hline & & & \\
\hline & & & \\
\hline & & & \\
\hline \multicolumn{4}{|l|}{ C. SITE INSPECTION PREPARATION } \\
\hline \multicolumn{4}{|c|}{$\begin{array}{l}\text { Assemble the following, as needed, to conduct inspections: } \\
\text { - ER SKD66 key to access the sites } \\
\text { - Radio, pager, etc. } \\
\text { - Previous letter report, inspection checklists, repair records, and as-built plans } \\
\text { - Camera, digital storage drive, extra batteries, and other miscellaneous support equipment }\end{array}$} \\
\hline \multicolumn{4}{|l|}{ D. SITE INSPECTION } \\
\hline \multicolumn{4}{|c|}{$\begin{array}{l}\text { - Visually inspect all features specifically described in this checklist and observe whether there is an indication that the use restriction inay have been } \\
\text { compromised. Entry into the fenced Contamination Areas is not required for the inspection. The checklist should be completed during the site } \\
\text { inspection. } \\
\text { - If a shaded box is checked, add detailed comments to document the results of the site inspection. Information provided should be of sufficient detail to } \\
\text { enable reconstruction of observations regarding field conditions. The completed checklist is part of the field record of the inspection. } \\
\text { - Field notes taken to assist in completion of this checklist will become part of the inspection record. No form is specified for field notes, and additional } \\
\text { field notes are not required if the checklist and associated attachments adequately describe site conditions. }\end{array}$} \\
\hline \multirow{2}{*}{$\begin{array}{l}\text { 1. Site Markers (CAS 12-06-09): } \\
\text { a. Have any sign posts been damaged or their anchoring } \\
\text { weakened? }\end{array}$} & YES & NO & EXPLANATION (required if shaded box is checked) \\
\hline & & $\sqrt{ }$ & \\
\hline \multicolumn{4}{|l|}{ b. Are all use restriction signs legible? } \\
\hline \multicolumn{4}{|l|}{ c. Are any of the 3 use restriction signs damaged or missing? } \\
\hline d. How many damaged or missing signs need to be replaced? & & & \\
\hline e. Are any use restriction signs down? & & & \\
\hline f. How many down signs need to be re-hung? & & 0 & \\
\hline $\begin{array}{l}\text { g. Do any Contamination Area or Underground Radioactive } \\
\text { Material Area signs need to be replaced or re-hung? }\end{array}$ & & $\sqrt{ }$ & \\
\hline
\end{tabular}




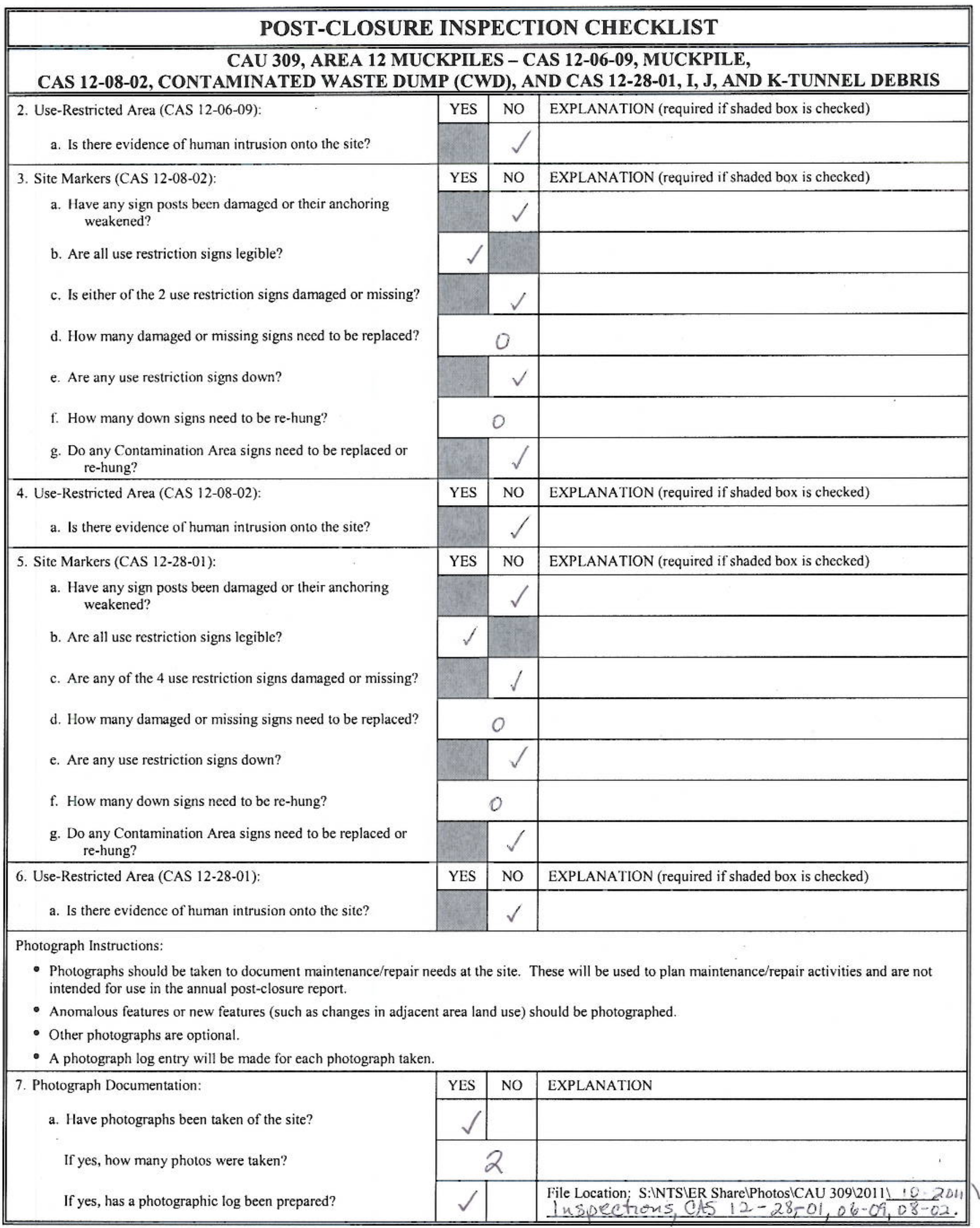




\begin{tabular}{|c|c|c|c|}
\hline \multicolumn{4}{|c|}{ POST-CLOSURE INSPECTION CHECKLIST } \\
\hline \multicolumn{4}{|c|}{$\begin{array}{l}\text { CAU 309, AREA 12 MUCKPILES - CAS 12-06-09, MUCKPILE, } \\
\text { CAS 12-08-02, CONTAMINATED WASTE DUMP (CWD), AND CAS 12-28-01, I, J, AND K-TUNNEL DEBRIS }\end{array}$} \\
\hline E. FIELD CONCLUSIONS & YES & NO & EXPLANATION (required if shaded box is checked) \\
\hline \multicolumn{4}{|l|}{ 1. Are more frequent inspections required? } \\
\hline 2. Are existing maintenance/repair actions satisfactory? & $\sqrt{ }$ & & \\
\hline \multicolumn{4}{|l|}{ 3. Are maintenance/repair actions necessary? } \\
\hline \multicolumn{4}{|c|}{$\begin{array}{l}\text { 4. Field Conclusions/Recommendations: Site, posts and signage, are in } \\
\text { good condition. }\end{array}$} \\
\hline \multicolumn{4}{|l|}{ - } \\
\hline \multicolumn{4}{|c|}{ F. CERTIFICATION: I have conducted this inspection in accordance with the Post-Closure Plan as recorded on this checklist and attachments. } \\
\hline \multicolumn{3}{|l|}{ Chief Inspector's Signature: /s/: Rebecca King } & Date: $\quad 10 / 19 / 11$ \\
\hline \multicolumn{3}{|l|}{ Printed Name: Rebecea King } & Title: PROTEQT NLNAGER \\
\hline \multicolumn{4}{|c|}{ G. VERIFICATION: I have reviewed this checklist and attachments and have verified that they are complete. } \\
\hline \multicolumn{4}{|l|}{ Signature: /s/: Reed J. Poderis for TAT . } \\
\hline
\end{tabular}


THIS PAGE INTENTIONALLY LEFT BLANK 


\section{CAU 322: AREAS 1 \& 3 RELEASE SITES AND INJECTION WELLS}


THIS PAGE INTENTIONALLY LEFT BLANK 
Inspection Requirement: Annual (through December 2011) then Every 5 Years (through December 2036)

\section{POST-CLOSURE INSPECTION CHECKLIST}

\section{CAU 322, AREAS 1 \& 3 RELEASE SITES AND INJECTION WELLS - CAS 03-20-05, INJECTION WELLS}

\begin{tabular}{|c|c|c|}
\hline Inspection Date and Time: & 1118111 & An nulael \\
\hline Date of Last Post-Closure Ir & pection: $\quad 1 i / 1 / 10$ & Reason for Last Post-Closure Inspection: $A$ \\
\hline
\end{tabular}

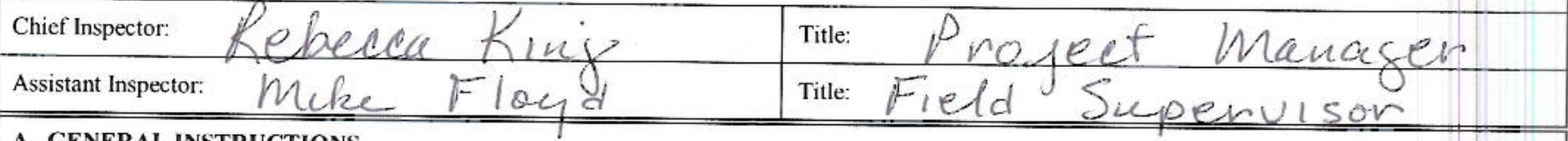

\section{A. GENERAL INSTRUCTIONS}

- Complete all checklist items.

- If a SHADED BOX is checked, provide detailed information and/or appropriate references to other documents that have the information.

- All documentation must be legible and clear.

\begin{tabular}{|c|c|c|c|}
\hline B. PREPARATION (To be completed prior to site visit) & YES & NO & EXPLANATION (required if shaded box is checked) \\
\hline 1. Has the Post-Closure Plan been reviewed? & & & \\
\hline 2. Have the previous inspection reports been reviewed? & & & \\
\hline 3. Were anomalies or trends detected on previous inspections? & & & \\
\hline $\begin{array}{l}\text { 4. Were maintenance or repair activities performed since the last } \\
\text { inspection? }\end{array}$ & & & Sigins \\
\hline
\end{tabular}

\section{SITE INSPECTION PREPARATION}

Assemble the following, as needed, to conduct inspections:

- Radio, pager, etc.

- Previous letter report, inspection checklists, repair records, and as-built plans

- Camera, digital storage drive, extra batteries, and other miscellaneous support equipment

\section{SITE INSPECTION}

- The site inspection is a walking inspection of the entire perimeter to visually inspect all features specifically described in this checklist and observe whether there is an indication that the use restriction may have been compromised. Entry into the fenced area is not required for the inspection. The checklist should be completed during the site inspection.

- If a shaded box is checked, add detailed comments to document the results of the site inspection. Information provided should be of sufficient detail to enable reconstruction of observations regarding field conditions. The completed checklist is part of the field record of the inspection.

- Field notes taken to assist in completion of this checklist will become part of the inspection record. No form is specified for field notes, and additional field notes are not required if the checklist and associated attachments adequately describe site conditions.

1. Site Markers:

a. Is there damage to the fence or fence posts?

b. Have any posts been damaged or their anchoring weakened?

c. Are all use restriction signs legible?

d. Are any use restriction signs damaged or missing?

e. How many damaged or missing signs need to be replaced?

f. Are any use restriction signs down?

g. How many down signs need to be re-hung?

h. Do any Underground Radioactive Material Area signs need to be replaced or re-hung?

\begin{tabular}{|c|c|c|}
\hline YES & NO & EXPLANATION (required if shaded box is checked) \\
\hline & $\checkmark$ & \\
\hline & $\sqrt{ }$ & \\
\hline$\sqrt{ }$ & & \\
\hline & $\sqrt{ }$ & \\
\hline & 0 & \\
\hline & 1 & \\
\hline & $R_{12}$ & $8 / 11$ \\
\hline & $\checkmark$ & \\
\hline
\end{tabular}


Inspection Requirement: Annual (through December 2011) then Every 5 Years (through December 2036)

\section{POST-CLOSURE INSPECTION CHECKLIST}

\section{CAU 322, AREAS 1 \& 3 RELEASE SITES AND INJECTION WELLS - CAS 03-20-05, INJECTION WELLS}

2. Use-Restricted Area:

a. Is there evidence of human intrusion onto the site?

Photograph Instructions:

- Photographs should be taken to document maintenance/repair needs at the site. These will be used to plan maintenance/repair activities and are not intended for use in the annual post-closure report.

- Anomalous features or new features (such as changes in adjacent area land use) should be photographed.

- Other photographs are optional.

- A photograph log entry will be made for each photograph taken.

3. Photograph Documentation:

a. Have photographs been taken of the site?

If yes, how many photos were taken?

If yes, has a photographic log been prepared?

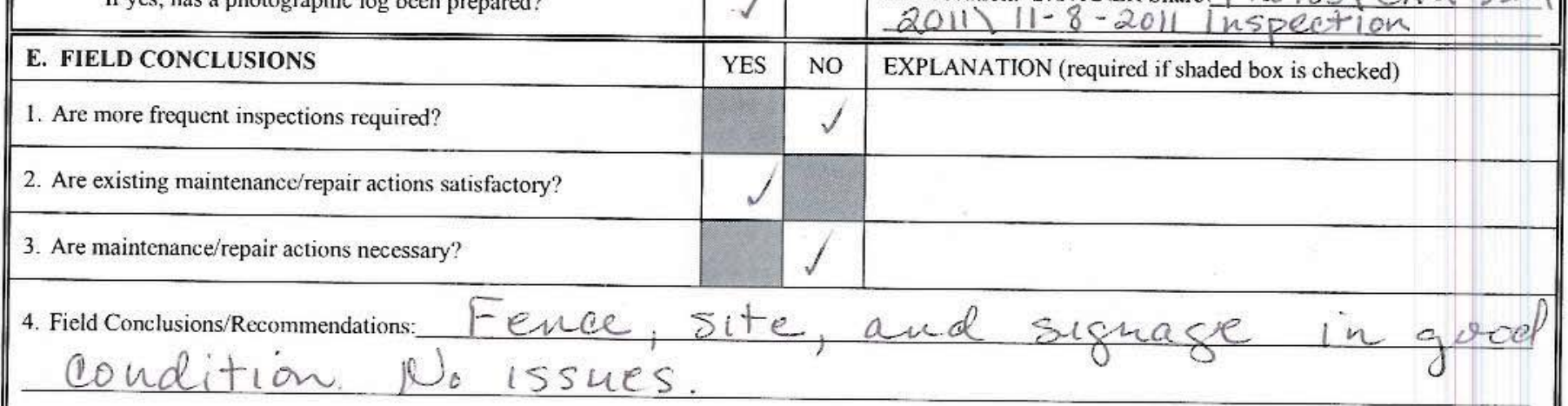

F. CERTIFICATION: I have conducted this inspection in accordance with the Post-Closure Plan as recorded on this checklist and attachments.

Chicf Inspector's Signature: /s/: Rebecca King

Printed Name: Rebecea Kins

G. VERIFICATION: I have reviewed this checklist and attachments and have verified that they are complete.

Signature: /s/: Reed J. Poderis for TAT

Date: $11 / 22 / 1$

Printed Name: Thomas A. Thiele (or designee) 
CAU 333: U-3auS DISPOSAL SITE 
THIS PAGE INTENTIONALLY LEFT BLANK 
Inspection Requirement: Every 5 Years (through December 2026)

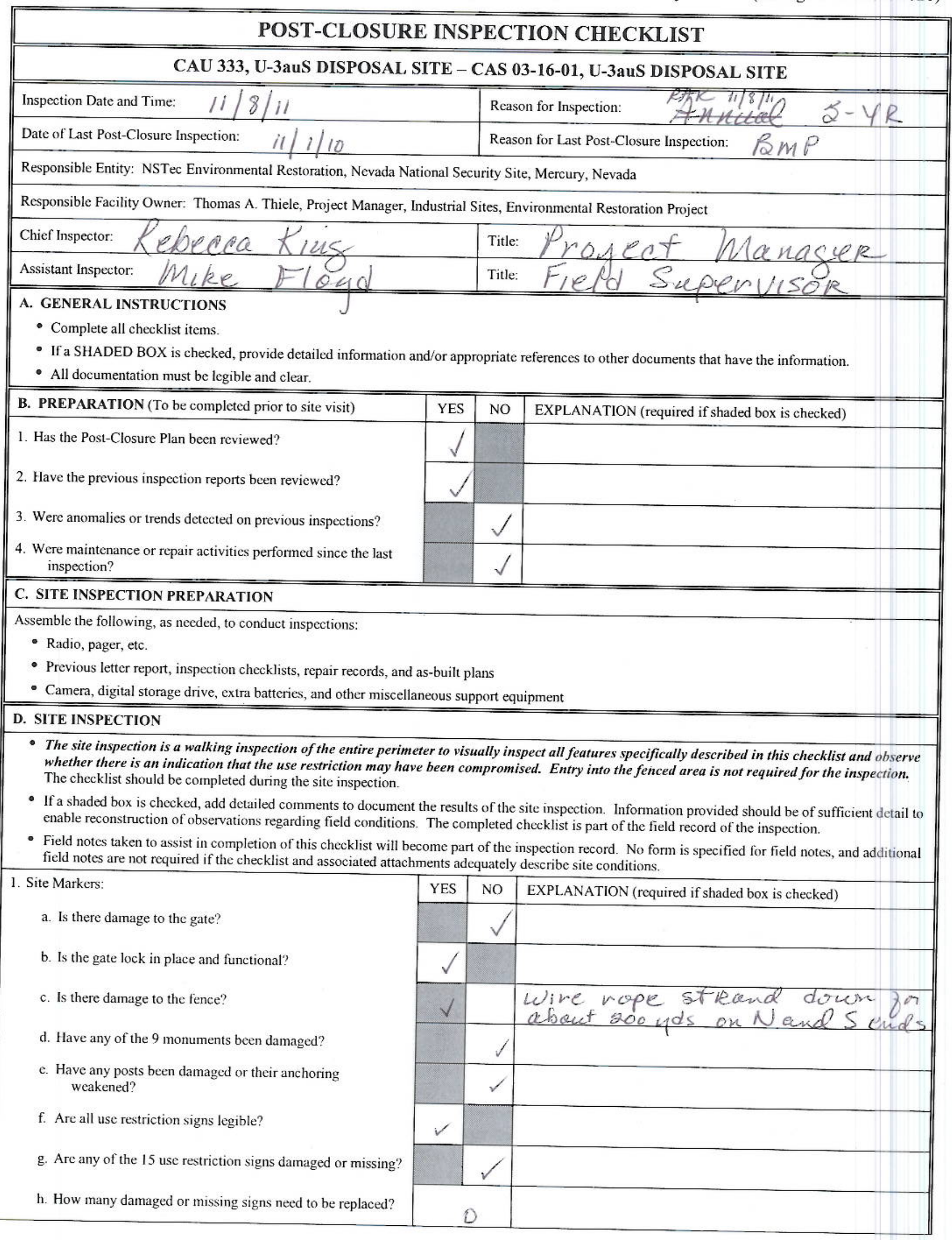


Inspection Requirement: Every 5 Years (through December 2026)

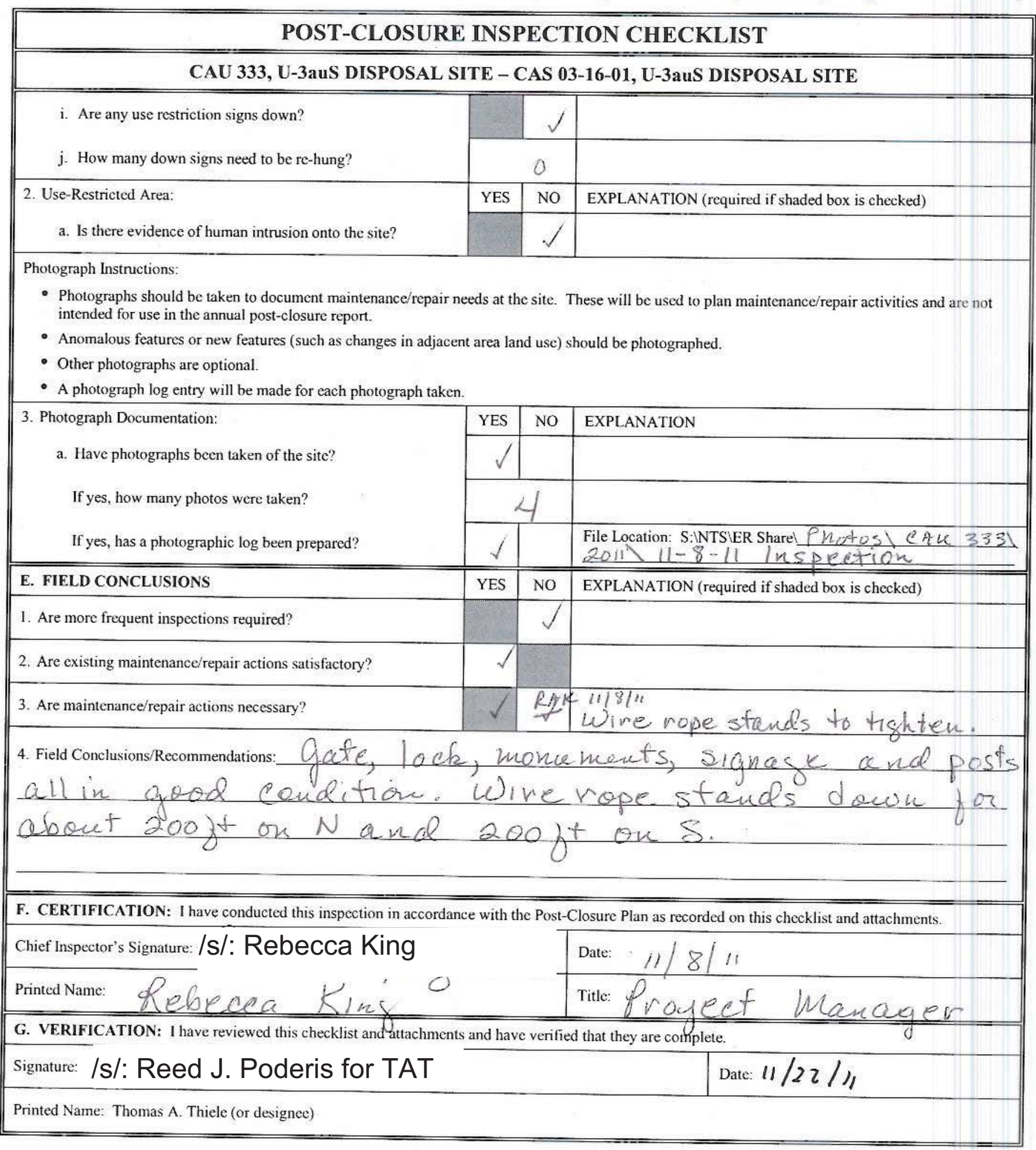


CAU 357: MUD PITS AND WASTE DUMP 
THIS PAGE INTENTIONALLY LEFT BLANK 


\begin{tabular}{|c|c|c|}
\hline \multicolumn{3}{|c|}{ POST-CLOSURE INSPECTION CHECKLIST } \\
\hline \multicolumn{3}{|c|}{ CAU 357, MUD PITS AND WASTE DUMP - CAS 04-26-03, LEAD BRICKS } \\
\hline & Reason for Inspection: A \\
\hline \multicolumn{2}{|l|}{ Date of Last Post-Closure Inspection: $\quad 11 / 9 / 10$} & Reason for Last Post-Closure Inspection: An Aural \\
\hline \multicolumn{3}{|c|}{ Responsible Entity: NSTec Environmental Restoration, Nevada National Security Site, Mercury, Nevada } \\
\hline \multicolumn{3}{|c|}{ Responsible Facility Owner: Thomas A. Thiele, Project Manager, Industrial Sites, Environmental Restoration Project } \\
\hline \multicolumn{3}{|c|}{ 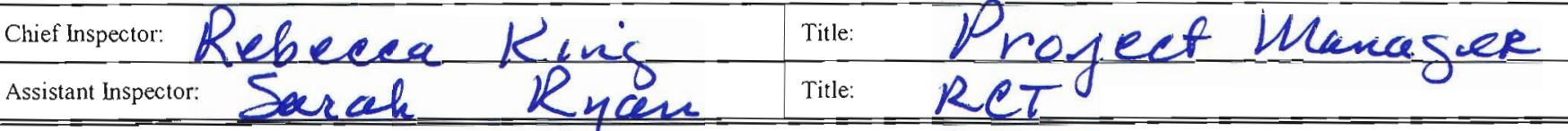 } \\
\hline \multicolumn{3}{|c|}{$\begin{array}{l}\text { A. GENERAL INSTRUCTIONS } \\
\text { - Complete all checklist items. } \\
\text { - If a SHADED BOX is checked, provide detailed information and/or appropriate references to other documents that have the information. } \\
\text { - All documentation must be legible and clear. }\end{array}$} \\
\hline B. PREPARATION (To be completed prior to site visit) & YES & EXPLANATION (required if shaded box is checked) \\
\hline \multicolumn{3}{|l|}{ 1. Has the Post-Closure Plan been reviewed? } \\
\hline \\
\hline \multicolumn{3}{|l|}{ 3. Were anomalies or trends detected on previous inspections? } \\
\hline \multicolumn{3}{|l|}{$\begin{array}{l}\text { 4. Were inaintenance or repair activities performed since the last } \\
\text { inspection? }\end{array}$} \\
\hline \multicolumn{3}{|l|}{ C. SITE INSPECTION PREPARATION } \\
\hline \multicolumn{3}{|c|}{$\begin{array}{l}\text { Assemble the following, as needed, to conduct inspections: } \\
\text { - Radio, pager, etc. } \\
\text { - Previous letter report, inspection checklists, repair records, and as-built plans } \\
\text { - Camera, digital storage drive, extra batteries, and other miscellaneous support equipment }\end{array}$} \\
\hline \multicolumn{3}{|l|}{ D. SITE INSPECTION } \\
\hline \multicolumn{3}{|c|}{$\begin{array}{l}\text { - Check in at the BEEF office prior to the inspection. } \\
\text { - Visually inspect all features specifically described in this checklist and observe whether there is an indication that the use restriction may have been } \\
\text { compromised. Entry into the fenced Radioactive Material Area that surrounds the site is not required for the inspection. The checklist should be } \\
\text { completed during the site inspection. } \\
\text { - If a shaded box is checked, add detailed comments to document the results of the site inspection. Infornation provided should be of sufficient detail to } \\
\text { enable reconstruction of observations regarding field conditions. The completed checklist is part of the field record of the inspection. } \\
\text { - Field notes taken to assist in completion of this checklist will become part of the inspection record. No form is specified for field notes, and additional } \\
\text { field notes are not required if the checklist and associated attachnents adequately describe site conditions. }\end{array}$} \\
\hline \multirow{2}{*}{\multicolumn{3}{|c|}{$\begin{array}{l}\text { 1. Site Markers: } \\
\begin{array}{l}\text { a. Have any sign posts been damaged or their anchoring } \\
\text { weakened? }\end{array}\end{array}$}} \\
\hline & & \\
\hline b. Are all use restriction signs legible? & $\checkmark$ & \\
\hline c. Are any use restriction signs damaged or missing? & & \\
\hline d. How many damaged or missing signs need to be rep & 0 & \\
\hline e. Are any use restriction signs down? & & \\
\hline f. How many down signs need to be re-hung? & 0 & \\
\hline 2. Use-Restricted Area: & YES & EXPLANATION (required if shaded box is checked) \\
\hline a. Is there evidence of human intrusion onto the site? & & \\
\hline
\end{tabular}




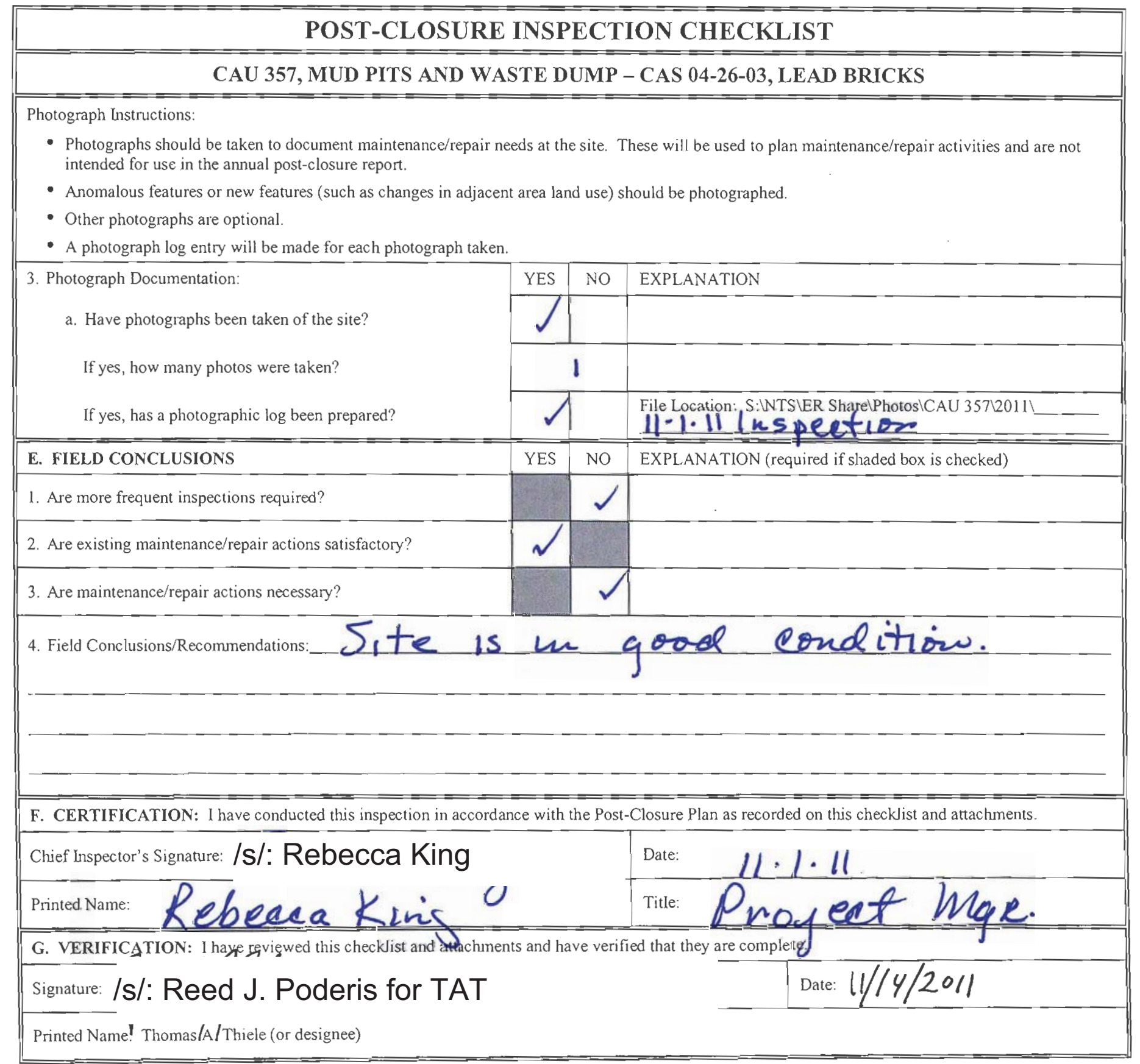




\begin{tabular}{|c|c|c|c|c|}
\hline \multicolumn{5}{|c|}{ POST-CLOSURE INSPECTION CHECKLIST } \\
\hline \multicolumn{5}{|c|}{ CAU 357, MUD PITS AND WASTE DUMP - CAS 10-09-06, MUD PIT; STAINS; MATERIAL } \\
\hline \multicolumn{2}{|c|}{ Inspection Date and Time: $\quad 11 / 1 / 11 \quad 2: 10 \mathrm{pm}$} & \multicolumn{3}{|c|}{ Reason for Inspection: } \\
\hline \multicolumn{2}{|l|}{ Date of Last Post-Closure Inspection: $\quad 10 / 25 / 10$} & \multicolumn{3}{|c|}{ Reason for Last Post-Closure Inspection: An $\mathrm{nuCl}$} \\
\hline \multicolumn{5}{|c|}{ Responsible Entity: NSTec Environmental Restoration, Nevada National Security Site, Mercury, Nevada } \\
\hline \multicolumn{5}{|c|}{ Responsible Facility Owner: Thomas A. Thiele, Project Manager, Industrial Sites, Environmental Restoration Project } \\
\hline \multicolumn{2}{|l|}{ Chief Inspector: Kebeeca Kins } & \multicolumn{3}{|c|}{ Title: Propeat Managen } \\
\hline \multicolumn{2}{|l|}{ Assistant Inspector: Sarah Kyan } & \multicolumn{3}{|c|}{ Title: $\quad 2 C$} \\
\hline \multicolumn{5}{|c|}{$\begin{array}{l}\text { A. GENERAL INSTRUCTIONS } \\
\text { - Complete all checklist items. } \\
\text { - If a SHADED BOX is checked, provide detailed information and/or appropriate references to other documents that have the information. } \\
\text { - All documentation must be legible and clear. }\end{array}$} \\
\hline B. PREPARATION (To be completed prior to site visit) & YES & NO & EXPLANATION (required if shaded box is checked) & \\
\hline \multicolumn{5}{|l|}{ 1. Has the Post-Closure Plan been reviewed? } \\
\hline \multicolumn{5}{|l|}{ 2. Have the previous inspection reports been reviewed? } \\
\hline \multicolumn{5}{|l|}{ 3. Were anomalies or trends detected on previous inspections? } \\
\hline \multicolumn{5}{|l|}{$\begin{array}{l}\text { 4. Were maintenance or repair activities performed since the last } \\
\text { inspection? }\end{array}$} \\
\hline \multicolumn{5}{|l|}{ C. SITE INSPECTION PREPARATION } \\
\hline \multicolumn{5}{|l|}{$\begin{array}{l}\text { Assemble the following, as needed, to conduct inspections: } \\
\text { - Radio, pager, etc. } \\
\text { - Previous letter report, inspection checklists, repair records, and } \\
\text { - Camera, digital storage drive, extra batteries, and other miscell }\end{array}$} \\
\hline \multicolumn{5}{|l|}{ D. SITE INSPECTION } \\
\hline \multicolumn{5}{|c|}{$\begin{array}{l}\text { - The site inspection is a walking inspection of the entire perimeter to visually inspect all features specifically described in this checklist and observe } \\
\text { whether there is an indication that the use restriction may have been compromised. Entry into the fenced area is not required for the inspection. } \\
\text { The checklist should be completed during the site inspection. } \\
\text { - If a shaded box is checked, add detailed comments to document the results of the site inspection. Information provided should be of sufficient detail to } \\
\text { enable reconstruction of observations regarding field conditions. The completed checklist is part of the field record of the inspection. } \\
\text { - Field notes taken to assist in completion of this checklist will become part of the inspection record. No form is specified for field notes, and additional } \\
\text { field notes are not required if the checklist and associated attachments adequately describe site conditions. }\end{array}$} \\
\hline \multirow{2}{*}{\multicolumn{5}{|c|}{$\begin{array}{l}\text { 1. Site Markers: } \\
\text { a. Is there damage to the fence or fence posts? }\end{array}$}} \\
\hline & & & & \\
\hline \multicolumn{5}{|l|}{$\begin{array}{l}\text { b. Have any sign posts been damaged or their anchoring } \\
\text { weakened? }\end{array}$} \\
\hline \multicolumn{5}{|l|}{ c. Are all use restriction signs legible? } \\
\hline \multicolumn{5}{|l|}{ d. Are any use restriction signs damaged or missing? } \\
\hline e. How many damaged or missing signs need to be replaced? & \multicolumn{2}{|c|}{0} & & \\
\hline \multicolumn{5}{|l|}{ f. Are any use restriction signs down? } \\
\hline g. How many down signs need to be re-hung? & \multicolumn{2}{|c|}{0} & & \\
\hline \multirow{2}{*}{$\begin{array}{l}\text { 2. Use-Restricted Area: } \\
\text { a. Is there evidence of human intrusion onto the site? }\end{array}$} & YES & NO & EXPLANATION (required if shaded box is checked) & \\
\hline & & & & \\
\hline
\end{tabular}

Page 1 of 2 


\section{POST-CLOSURE INSPECTION CHECKLIST}

\section{CAU 357, MUD PITS AND WASTE DUMP - CAS 10-09-06, MUD PIT; STAINS; MATERIAL}

Photograph Instructions:

- Photographs should be taken to document maintenance/repair needs at the site. These will be used to plan maintenance/repair activities and are not intended for use in the annual post-closure report.

- Anomalous features or new features (such as changes in adjacent area land use) should be photographed.

- Other photographs are optional.

- A photograph log entry will be made for each photograph taken.

3. Photograph Documentation:

a. Have photographs been taken of the site?

If yes, how many photos were taken?

If yes, has a photographic log been prepared?

\begin{tabular}{l|l|l|l} 
YES & NO & EXPLANATION
\end{tabular}

\begin{tabular}{|l|l|l|l|}
\hline \hline E. FIELD CONCLUSIONS & YES & NO & EXPLANATION (required if shaded box is checked) \\
\hline 1. Are more frequent inspections required? & & \\
\hline 2. Are existing maintenance/repair actions satisfactory? & \\
\hline 3. Are maintenance/repair actions necessary? & \\
4. Field Conclusions/Recommendations: &
\end{tabular}

F. CERTIFICATION: I have conducted this inspection in accordance with the Post-Closure Plan as recorded on this checklist and attachments.

Chief Inspector's Signature: /S/: Rebecca King

Printed Name:

\section{Rebeca Kins}

()

G. VERIFICATION: I have reviewed this checklist and attachments and have verified that they are complete.

Signature: /s/: Reed J. Poderis for TAT Date: $11 / 14 / 1 /$

Printed Name: Thomas A. Thiele (or designee) 


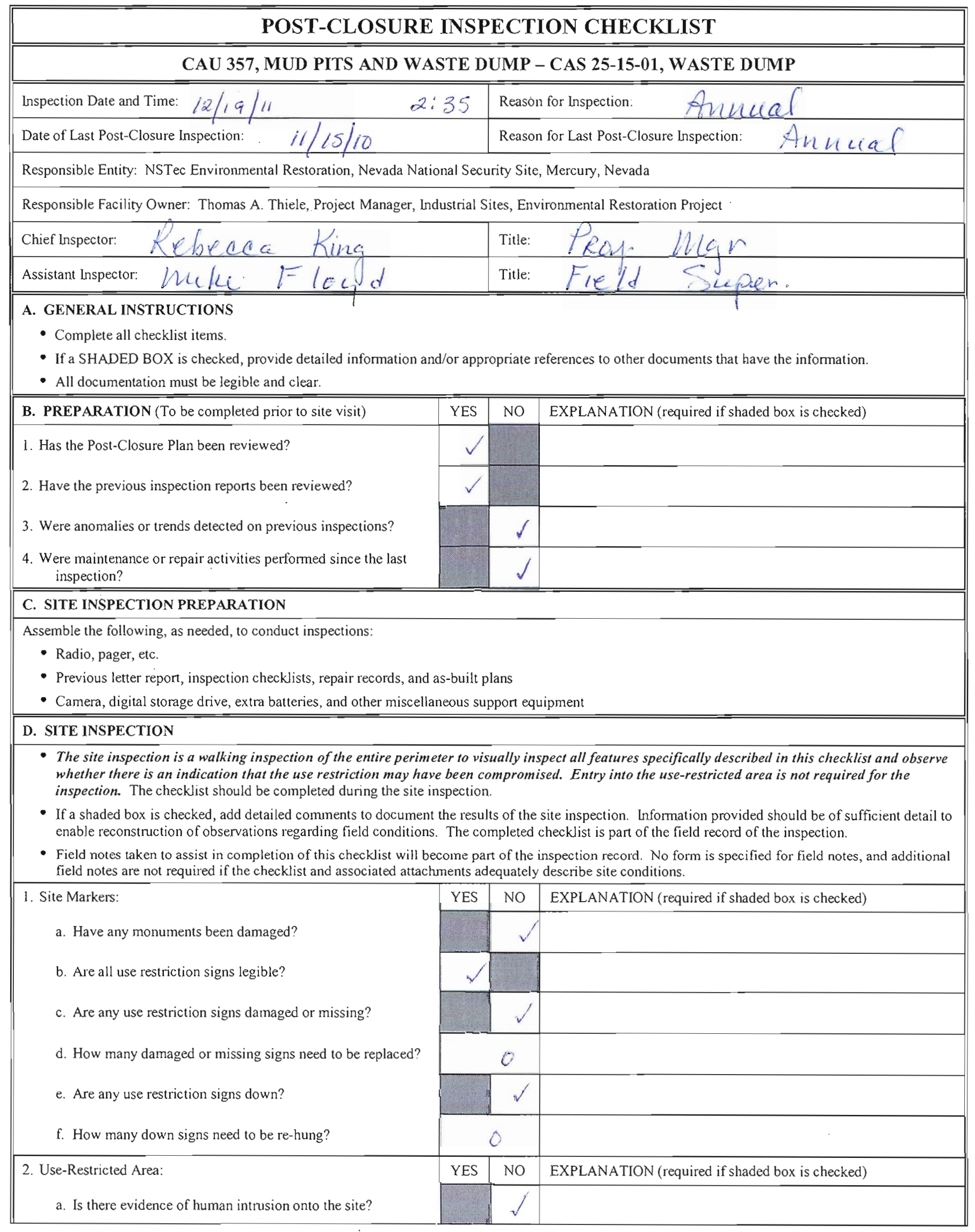




\section{POST-CLOSURE INSPECTION CHECKLIST}

\section{CAU 357, MUD PITS AND WASTE DUMP - CAS 25-15-01, WASTE DUMP}

Photograph Instructions:

- Photographs should be taken to document maintenance/repair needs at the site. These will be used to plan maintenance/repair activities and are not intended for use in the annual post-closure report.

- Anomalous features or new features (such as changes in adjacent area land use) should be photographed.

- Other photographs are optional.

- A photograph log entry will be made for each photograph taken.

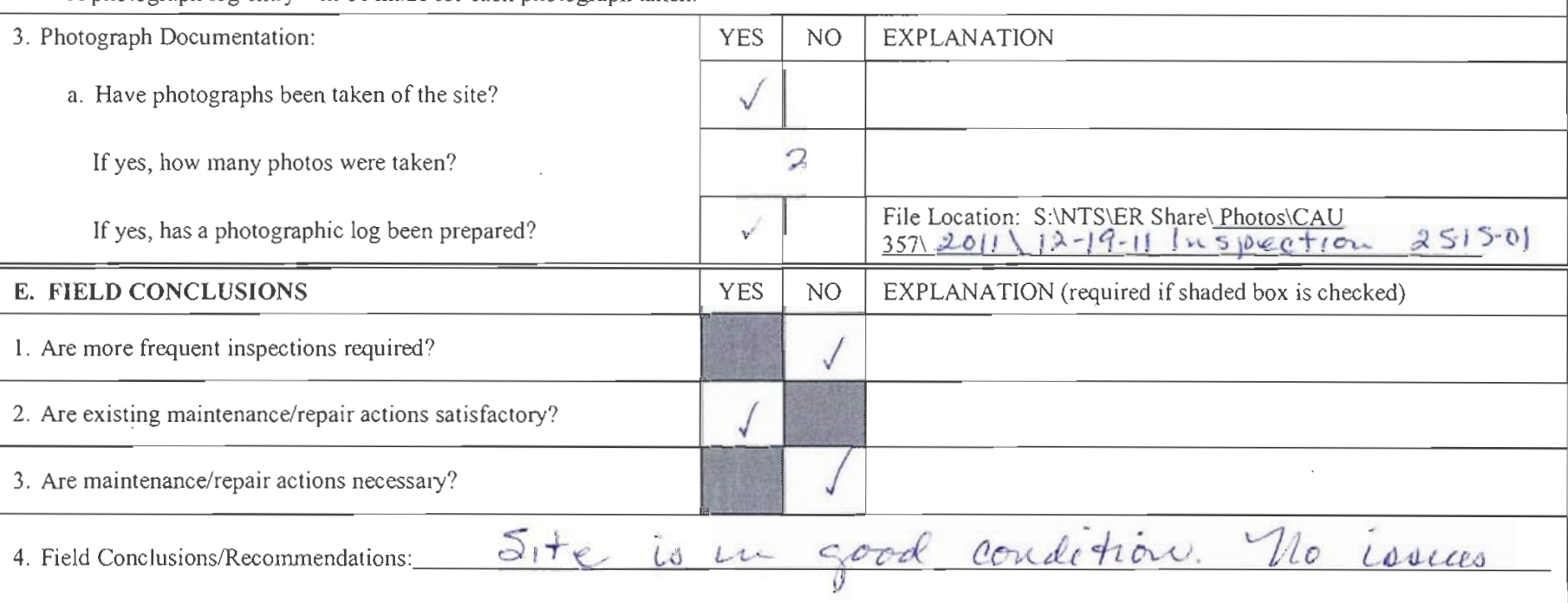

F. CERTIFICATION: I have conducted this inspection in accordance with the Post-Closure Plan as recorded on this checklist and attachments

Chief Inspector's Signature:/s/: Rebecca King

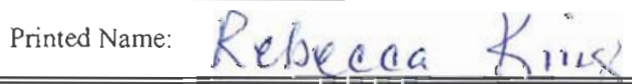

Date: $12 \cdot 19 \cdot 11$

G. VERIFICATION: I have reviewed this checklist and attachments and have verified that they are complete.

Signature: /s/: Reed J. Poderis for TAT

Date: $1 / 3 / 2012$

Printed Name: Thomas A. Thiele (or designee) 
CAU 528: POLYCHLORINATED BIPHENYLS CONTAMINATION 
THIS PAGE INTENTIONALLY LEFT BLANK 


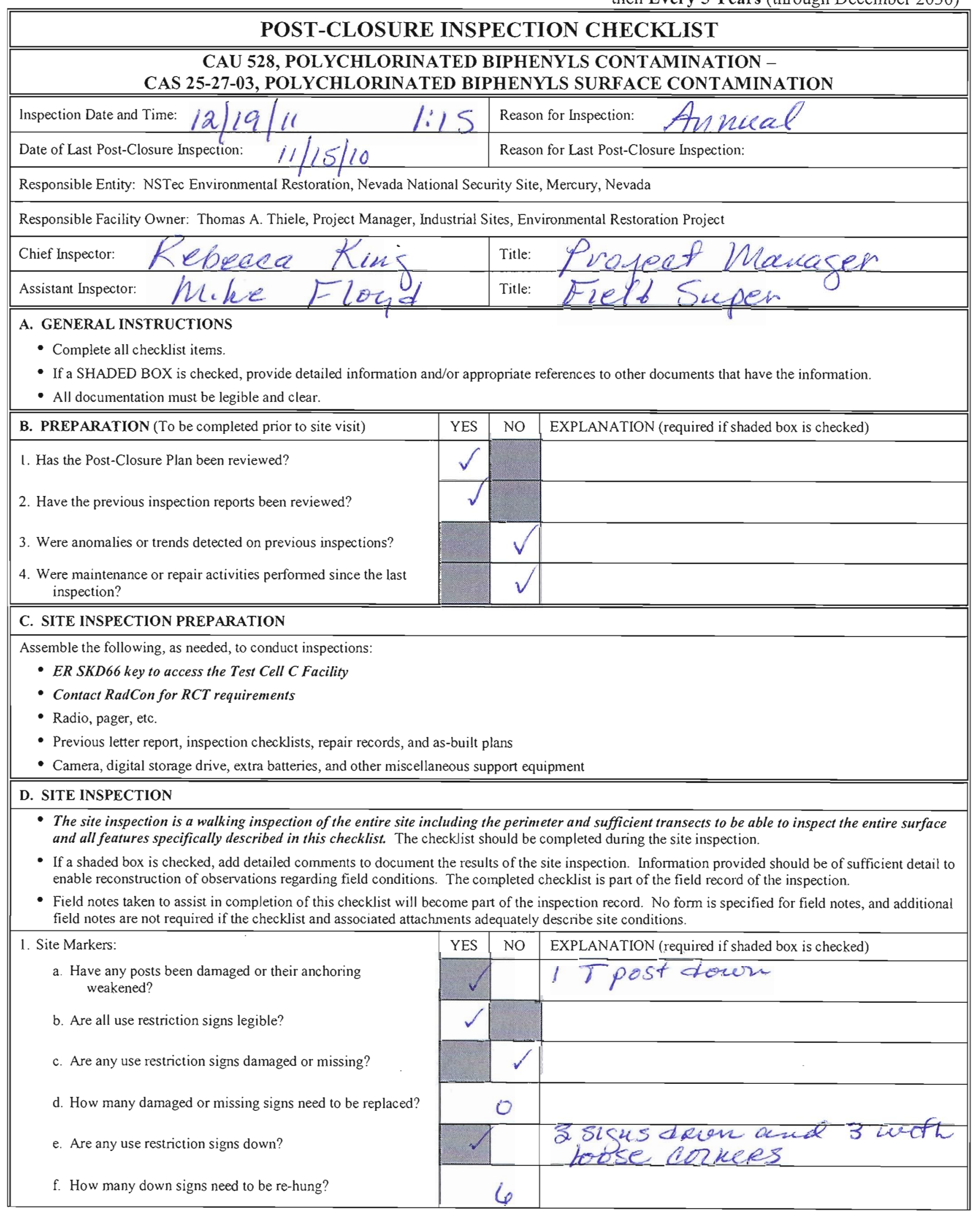




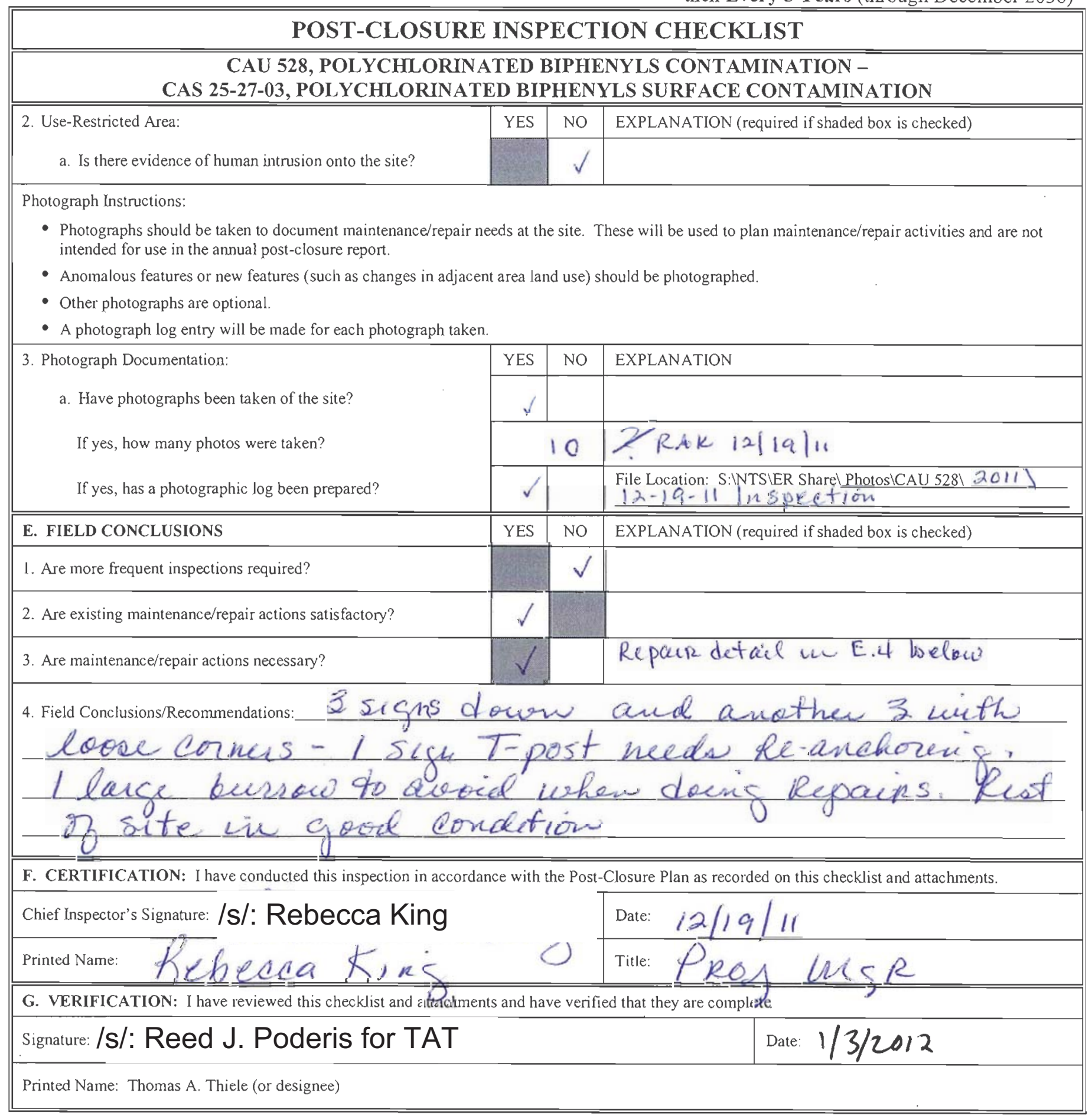


CAU 529: AREA 25 CONTAMINATED MATERIALS 
THIS PAGE INTENTIONALLY LEFT BLANK 


\section{POST-CLOSURE INSPECTION CHECKLIST}

\section{CAU 529, AREA 25 CONTAMINATED MATERIALS - CAS 25-23-17, CONTAMLNATED WASH PARCELS E \& H}

\begin{tabular}{|l|l|l|l}
\hline Inspection Date and Time: $12 / 19 / 2$ & Reason for Inspection: \\
\hline Date of Last Post-Closure Inspection: & Reason for Last Post-Closure Inspection: \\
\hline Responsible Entity: NSTec Environmental Restoration, Nevada National Security Site, Mercury, Nevada
\end{tabular}

Responsible Entity: NSTec Environmental Restoration, Nevada National Security Site, Mercury, Nevada

Responsible Facility Owner: Thomas A. Thiele, Project Manager, Industrial Sites, Environmental Restoration Project

Assistant Inspector:

\section{A. GENERAL INSTRUCTIONS}

- Complete all checklist items.

- If a SHADED BOX is checked, provide detailed information and/or appropriate references to other documents that have the information.

- All documentation must be legible and clear.

B. PREPARATION (To be completed prior to site visit)

1. Has the Post-Closure Plan been reviewed?

2. Have the previous inspection reports been reviewed?

3. Were anomalies or trends detected on previous inspections?

4. Were maintenance or repair activities performed since the last inspection?

\section{SITE INSPECTION PREPARATION}

Assemble the following, as needed, to conduct inspections:

- ER SKD66 key to access the Test Cell C Facility

- Contact RadCon for RCT requirements

- Radio, pager, etc.

- Previous letter report, inspection checklists, repair records, and as-built plans

- Camera, digital storage drive, extra batteries, and other miscellaneous support equipment

\section{SITE INSPECTION}

- The site inspection is a walking inspection of the entire perimeter to visually inspect all features specifically described in this checklist and observe whether there is an indication that the use restriction may have been compromised. Entry into the fenced area is not required for the inspection. The checklist should be completed during the site inspection.

- If a shaded box is checked, add detailed comments to document the results of the site inspection. Information provided should be of sufficient detail to enable reconstruction of observations regarding field conditions. The completed checklist is part of the field record of the inspection.

- Field notes taken to assist in completion of this checklist will become part of the inspection record. No form is specified for field notes, and additional field notes are not required if the checklist and associated attachments adequately describe site conditions.

1. Site Markers (Parcel E):

a. Is there damage to the fence and fence posts?

b. Have any sign posts been damaged or their anchoring weakened?

c. Are all use restriction signs legible?

d. Are any use restriction signs damaged or missing?

e. How many damaged or missing signs need to be replaced?

f. Are any use restriction signs down?

g. How many down signs need to be re-hung?

\begin{tabular}{|c|c|c|}
\hline YES & NO & EXPLANATION (required if shaded box is checked) \\
\hline & $\checkmark$ & \\
\hline$\sqrt{ }$ & & 2 sugus inside tele fince \\
\hline & 2 & 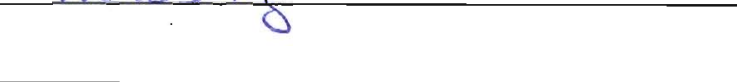 \\
\hline & $\checkmark$ & \\
\hline & 0 & \\
\hline
\end{tabular}




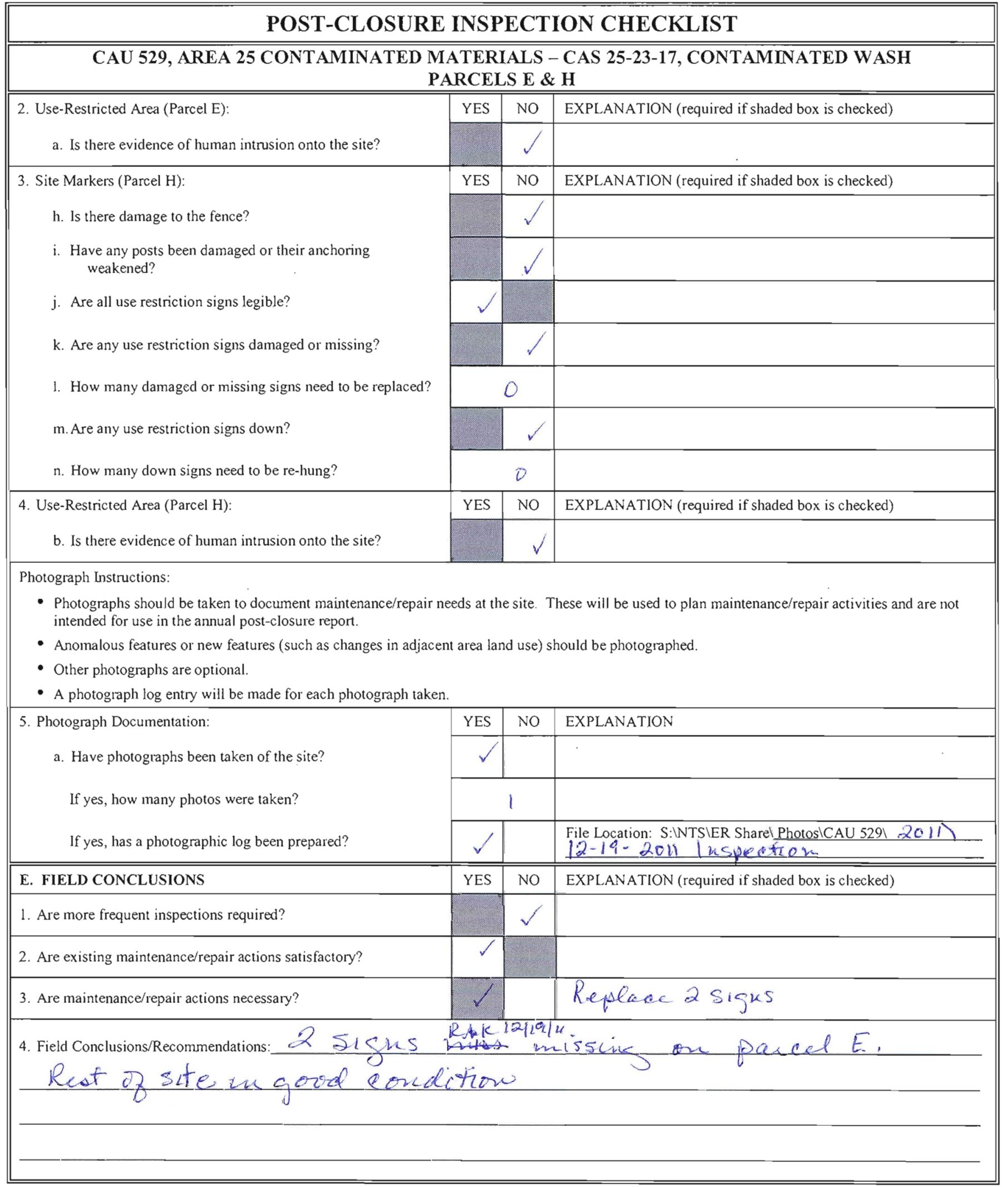




\begin{tabular}{|l||}
\hline \multicolumn{3}{|c||}{ POST-CLOSURE INSPECTION CHECKLIST } \\
\hline \hline \multicolumn{2}{|c||}{ CAU 529, AREA 25 CONTAMINATED MATERIALS - CAS 25-23-17, CONTAMINATED WASH } \\
PARCES E \& H \\
\hline \hline F. CERTIFICATION: I have conducted this inspection in accordance with the Post-Closure Plan as recorded on this checklist and attachments. \\
\hline Chief lnspector's Signature: /S/: Rebecca King \\
\hline Printed Name:
\end{tabular}


THIS PAGE INTENTIONALLY LEFT BLANK 
CAU 539: AREAS 25 AND 26 RAILROAD TRACKS 
THIS PAGE INTENTIONALLY LEFT BLANK 


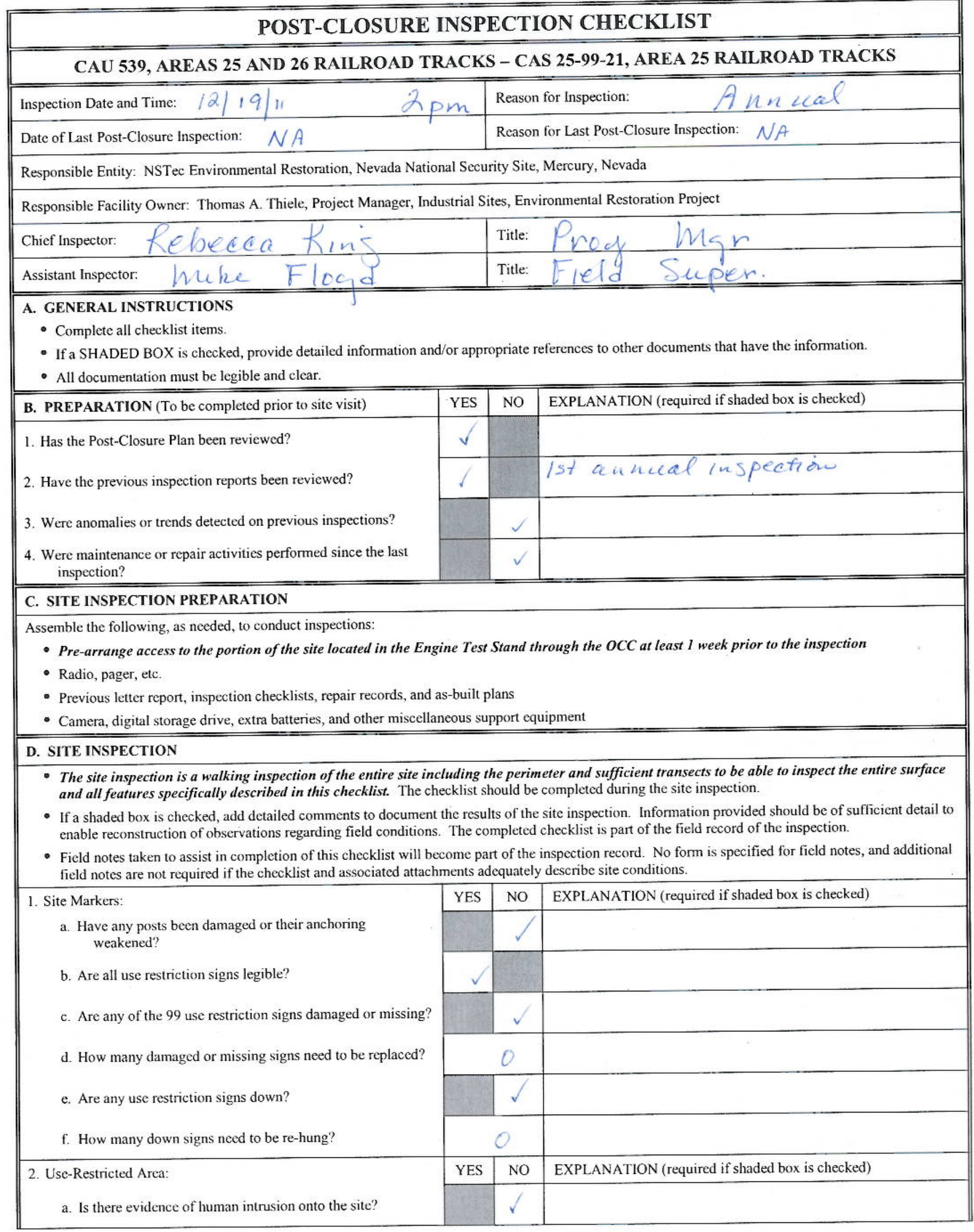




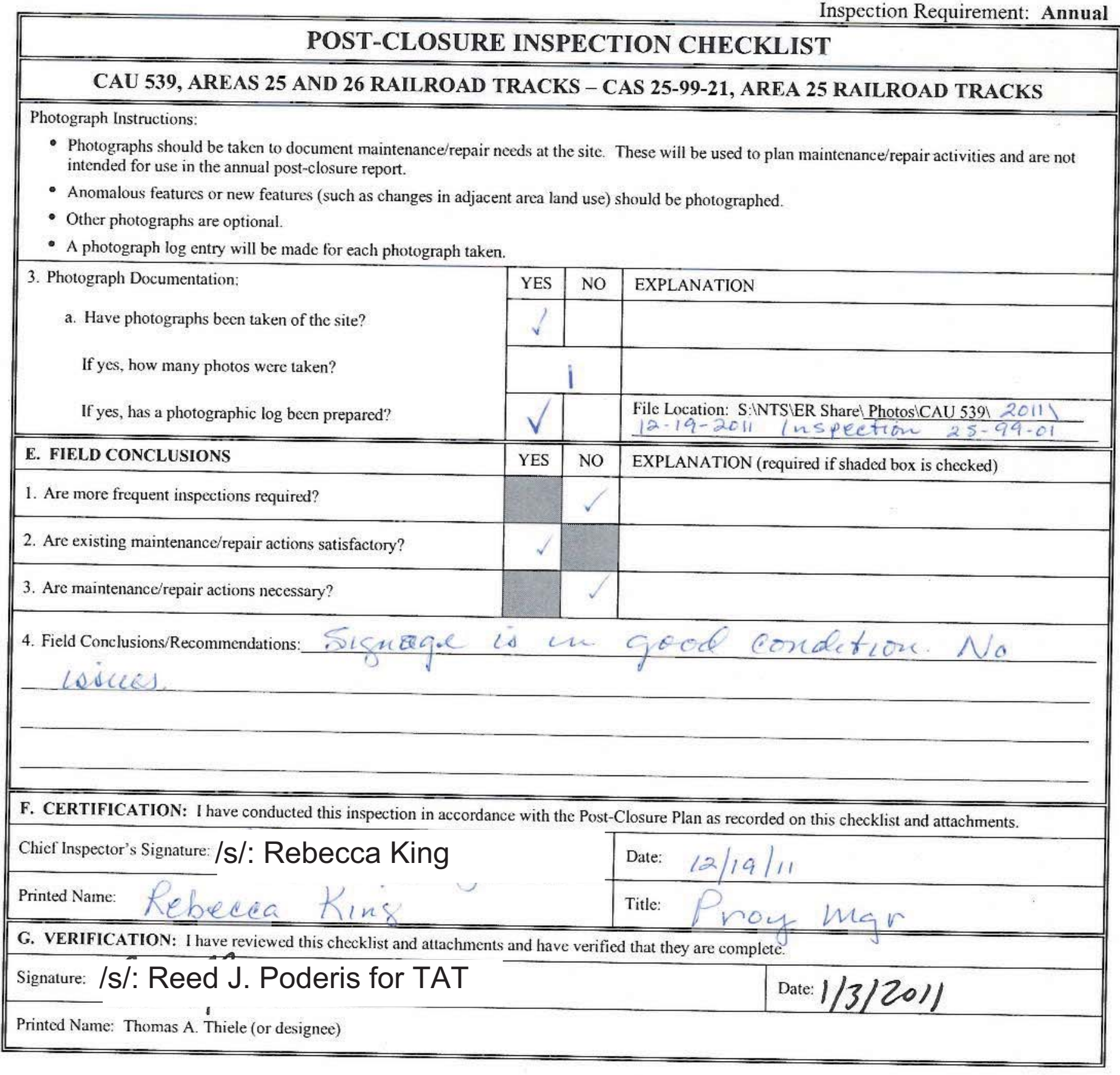


CAU 542: DISPOSAL HOLES 
THIS PAGE INTENTIONALLY LEFT BLANK 


\section{POST-CLOSURE INSPECTION CHECKLIST}

\section{CAU 542, DISPOSAL HOLES - CAS 03-20-07, UD-3a DISPOSAL HOLE}

\begin{tabular}{|l|l|l}
\hline \hline Inspection Date and Time: $11 / 8 / 11$ & Reason for Inspection: \\
\hline Date of Last Post-Closure Inspection: $1 / 1 / i 0$ & Reason for Last Post-Closure Inspection: \\
\hline Responsible Entity: NSTec Environmental Restoration, Nevada National Security Site, Mercury, Nevada
\end{tabular}

Responsible Facility Owner: Thomas A. Thiele, Project Manager, Industrial Sites, Environmental Restoration Project

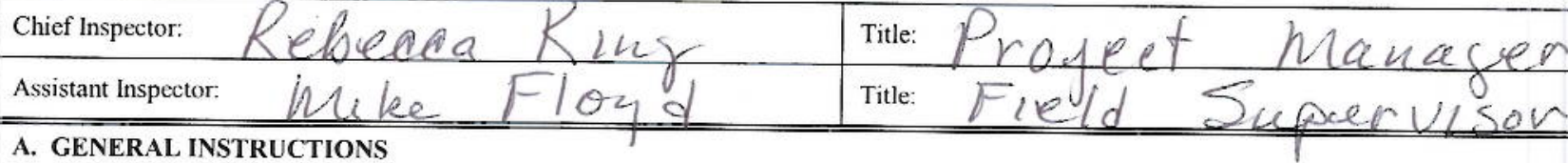

RUCTIONS

- Complete all checklist items.

- If a SHADED BOX is checked, provide detailed information and/or appropriate references to other documents that have the information.

- All documentation must be legible and clear.

B. PREPARATION (To be completed prior to site visit)

1. Has the Post-Closure Plan been reviewed?

2. Have the previous inspection reports been reviewed?

3. Were anomalies or trends detected on previous inspections?

4. Were maintenance or repair activities performed since the last inspection?

\section{SITE INSPECTION PREPARATION}

Assemble the following, as needed, to conduct inspections:

- Radio, pager, etc.

- Previous letter report, inspection checklists, repair records, and as-built plans

- Camera, digital storage drive, extra batteries, and other miscellaneous support equipment

\section{SITE INSPECTION}

- The site inspection is a walking inspection of the entire site including the perimeter and sufficient transects to be able to inspect the entire surface and all features specifically described in this checklist. The checklist should be completed during the site inspection.

- If a shaded box is checked, add detailed comments to document the results of the site inspection. Information provided should be of sufficient detail to enable reconstruction of observations regarding field conditions. The completed checklist is part of the field record of the inspection.

- Field notes taken to assist in completion of this checklist will become part of the inspection record. No form is specified for field notes, and additional field notes are not required if the checklist and associated attachments adequately describe site conditions.

1. Site Markers:

a. Have any posts been damaged or their anchoring weakened?

b. Are all use restriction signs legible?

c. Are any of the 4 use restriction signs damaged or missing?

d. How many damaged or missing signs need to be replaced?

e. Are any use restriction signs down?

f. How many down signs need to be re-hung?

2. Use-Restricted Area:

a. Is there evidence of human intrusion onto the site?

\begin{tabular}{|r|r|l||}
\hline YES & NO & EXPLANATION (required if shaded box is checked) \\
\hline & & \\
\hline & & \\
\hline & $\checkmark$ & \\
\hline & & \\
\hline & $\sqrt{ }$ & \\
\hline & & \\
\hline YES & NO & EXPLANATION (required if shaded box is checked) \\
\hline & $\sqrt{ }$ & \\
\hline
\end{tabular}




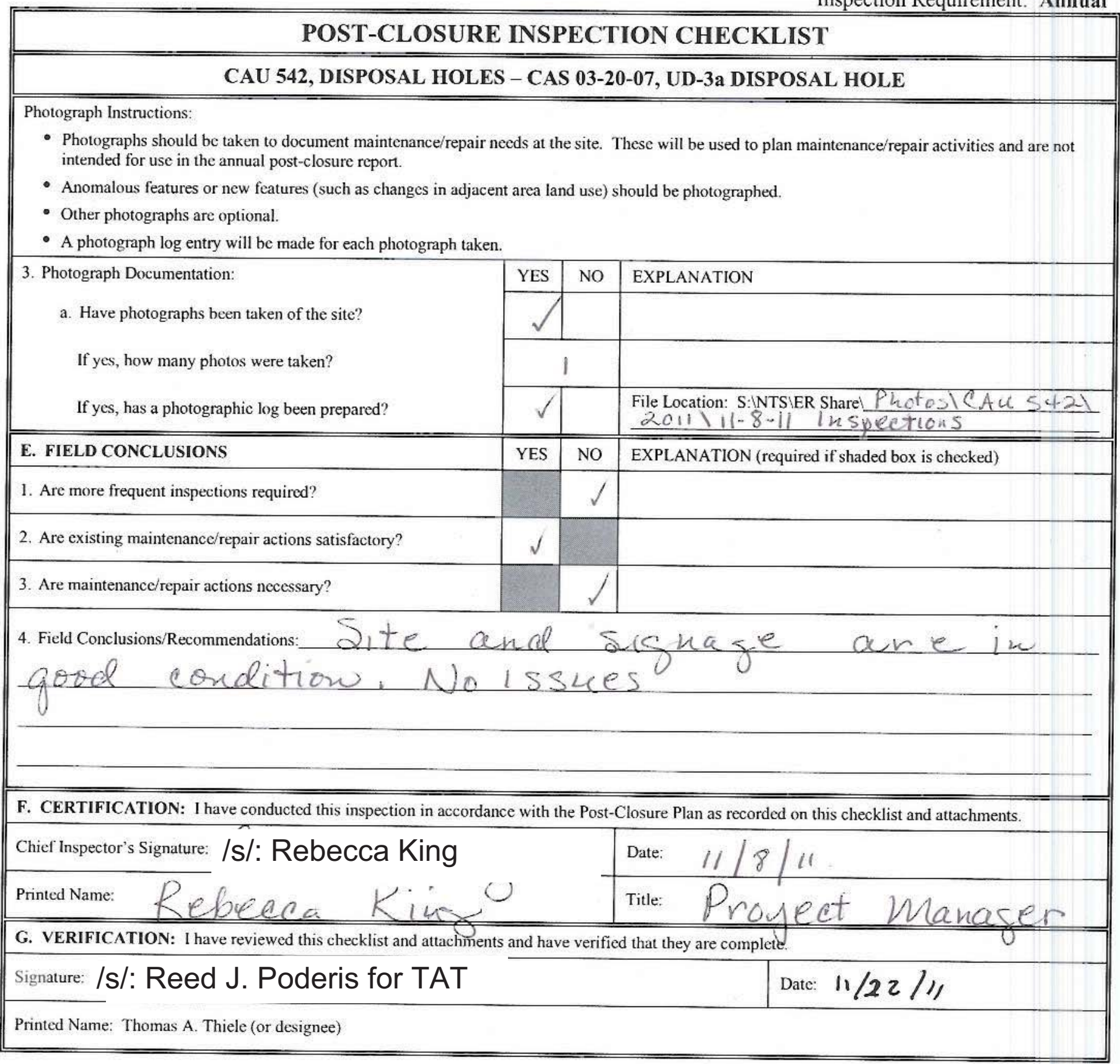




\section{POST-CLOSURE INSPECTION CHECKLIST}

\section{CAU 542, DISPOSAL HOLES - CAS 03-20-09, UD-3b DISPOSAL HOLE}

\begin{tabular}{|c|c|c|}
\hline Inspection Date and Time: $11 / 8$ & $11 \quad 10 ; 15$ arn & Reason for Inspection: \\
\hline Date of Last Post-Closure Inspection: & $11 / 1 / 10$ & Reason for Last Post-Closure Inspection: $4 k$ L L a \\
\hline
\end{tabular}

Responsible Entity: NSTec Environmental Restoration, Nevada National Security Site, Mercury, Nevada

Responsible Facility Owner: Thomas A. Thiele, Project Manager, Industrial Sites, Environmental Restoration Project

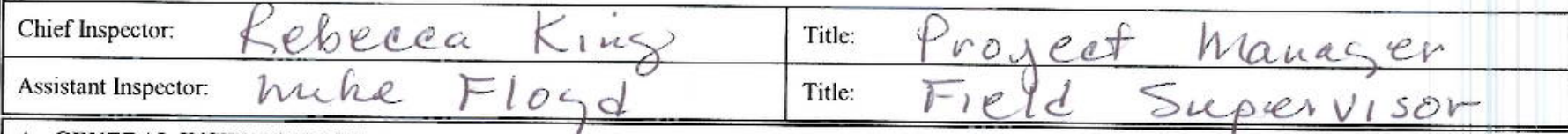

A. GENERAL INSTRUCTIONS

- Complete all checklist items.

- If a SHADED BOX is checked, provide detailed information and/or appropriate references to other documents that have the information.

- All documentation must be legible and clear.

\begin{tabular}{|c|c|c|c|}
\hline B. PREPARATION (To be completed prior to site visit) & YES & NO & EXPLANATION (required if shaded box is checked) \\
\hline \multicolumn{4}{|l|}{ 1. Has the Post-Closure Plan been reviewed? } \\
\hline \multicolumn{4}{|l|}{ 2. Have the previous inspection reports been reviewed? } \\
\hline \multicolumn{4}{|l|}{ 3. Were anomalies or trends detected on previous inspections? } \\
\hline $\begin{array}{l}\text { 4. Were maintenance or repair activities performed since the last } \\
\text { inspection? }\end{array}$ & & & 1 sign replaced \\
\hline
\end{tabular}

\section{SITE INSPECTION PREPARATION}

Assemble the following, as needed, to conduct inspections:

- Radio, pager, etc.

- Previous letter report, inspection checklists, repair records, and as-built plans

- Camera, digital storage drive, extra batteries, and other miscellaneous support equipment

\section{SITE INSPECTION}

- The site inspection is a walking inspection of the entire site including the perimeter and sufficient transects to be able to inspect the entire surface and all features specifically described in this checklist. The checklist should be completed during the site inspection.

- If a shaded box is checked, add detailed comments to document the results of the site inspection. Information provided should be of sufficient detail to enable reconstruction of observations regarding field conditions. The completed checklist is part of the field record of the inspection.

- Field notes taken to assist in completion of this checklist will become part of the inspection record. No form is specified for field notes, and additional field notes are not required if the checklist and associated attachments adequately describe site conditions.

1. Site Markers:

a. Have any posts been damaged or their anchoring weakened?

b. Are all use restriction signs legible?

c. Are any of the 4 use restriction signs damaged or missing?

d. How many damaged or missing signs need to be replaced?

e. Are any use restriction signs down?

f. How many down signs need to be re-hung?

2. Use-Restricted Area:

a. Is there evidence of human intrusion onto the site?

\begin{tabular}{|c|c|c|}
\hline YES & $\mathrm{NO}$ & EXPLANATION (required if shaded box is checked) \\
\hline & & 7 \\
\hline & & \\
\hline & & \\
\hline & & \\
\hline & & \\
\hline YES & NO & EXPLANATION (required if shaded box is checked) \\
\hline & & \\
\hline
\end{tabular}


POST-CLOSURE INSPECTION CHECKLIST

\section{CAU 542, DISPOSAL HOLES - CAS 03-20-09, UD-3b DISPOSAL HOLE}

Photograph Instructions:

- Photographs should be taken to document maintenance/repair needs at the site. These will be used to plan maintenance/repair activities and are not intended for use in the annual post-closure report.

- Anomalous features or new features (such as changes in adjacent area land use) should be photographed.

- Other photographs are optional.

- A photograph log entry will be made for each photograph taken.

3. Photograph Documentation:

a. Have photographs been taken of the site?

If yes, how many photos were taken?

If yes, has a photographic log been prepared?

\section{E. FIELD CONCLUSIONS}

1. Are more frequent inspections required?

2. Are existing maintenance/repair actions satisfactory?

3. Are maintenance/repair actions necessary?

\section{\begin{tabular}{l|l|l} 
YES & NO & EXPLANATION
\end{tabular}}

$1 /$ I

4. Ficld Conclusions/Recommendations:

condition No isslees.

F. CERTIFICATION: I have conducted this inspection in accordance with the Post-Closure Plan as recorded on this checklist and attachments.

Chief Inspector's Signature: /s/: Rebecca King

Printed Name: Lebleca Kins

G. VERIFICATION: I have reviewed this checklist and attachments and have verified that they are complete.

Signature: /s/: Reed J. Poderis for TAT

Date: $11 / 22 / 1$

Printed Name: Thomas A. Thiele (or designee) 
POST-CLOSURE INSPECTION CHECKLIST

\section{CAU 542, DISPOSAL HOLES - CAS 03-20-10, UD-3c DISPOSAL HOLE}

\begin{tabular}{ll|l}
\hline Inspection Date and Time: $1 / / 8 / i 1$ & Reason for Inspection:
\end{tabular}

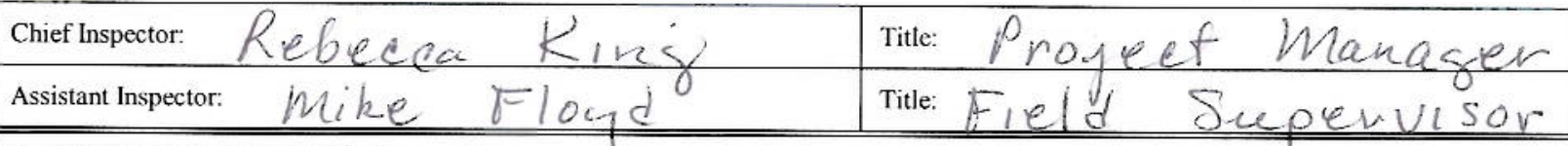
A. GENERAL INSTRUCTIONS

- Complete all checklist items.

- If a SHADED BOX is checked, provide detailed information and/or appropriate references to other documents that have the information.

- All documentation must be legible and clear.

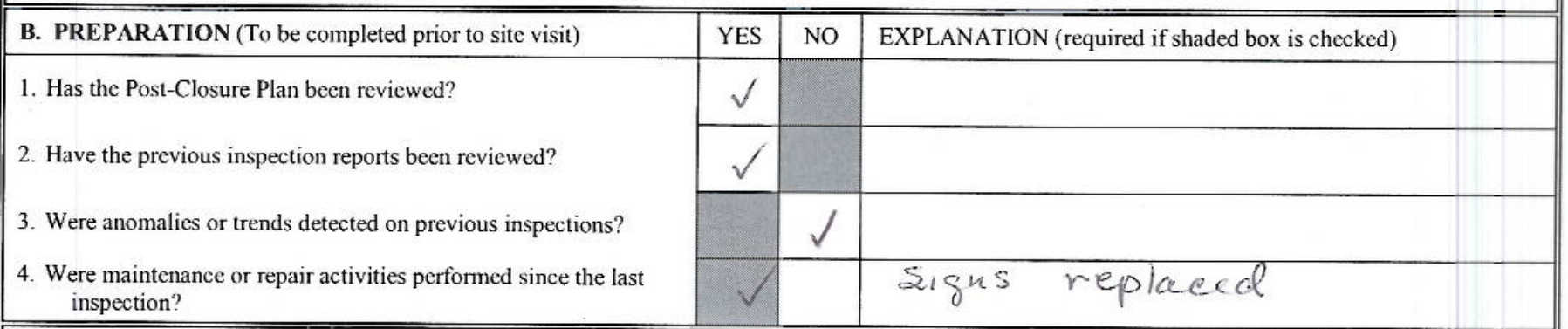

\section{SITE INSPECTION PREPARATION}

Assemble the following, as needed, to conduct inspections:

- Radio, pager, etc.

- Previous letter report, inspection checklists, repair records, and as-built plans

- Camera, digital storage drive, extra batteries, and other miscellaneous support equipment

\section{SITE INSPECTION}

- The site inspection is a walking inspection of the entire site including the perimeter and sufficient transects to be able to inspect the entire surface and all features specifically described in this checklist. The checklist should be completed during the site inspection.

- If a shaded box is checked, add detailed comments to document the results of the site inspection. Information provided should be of sufficient detail to enable reconstruction of observations regarding field conditions. The completed checklist is part of the field record of the inspection.

- Field notes taken to assist in completion of this checklist will become part of the inspection record. No form is specified for field notes, and additional field notes are not required if the checklist and associated attachments adequately describe site conditions.

1. Site Markers:

a. Have any posts been damaged or their anchoring weakened?

b. Are all use restriction signs legible?

c. Are any of the 4 use restriction signs damaged or missing?

d. How many damaged or missing signs need to be replaced?

e. Are any use restriction signs down?

f. How many down signs need to be re-hung?

2. Use-Restricted Area:

a. Is there evidence of human intrusion onto the site?

\begin{tabular}{|r|r|l||}
\hline YES & NO & EXPLANATION (required if shaded box is checked) \\
\hline & $\checkmark$ & \\
\hline$\checkmark$ & & \\
\hline & & \\
\hline & & \\
\hline & & \\
\hline & $\checkmark$ & \\
\hline & & \\
\hline YES & NO & EXPLANATION (required if shaded box is checked) \\
\hline & $\checkmark$ & \\
\hline
\end{tabular}




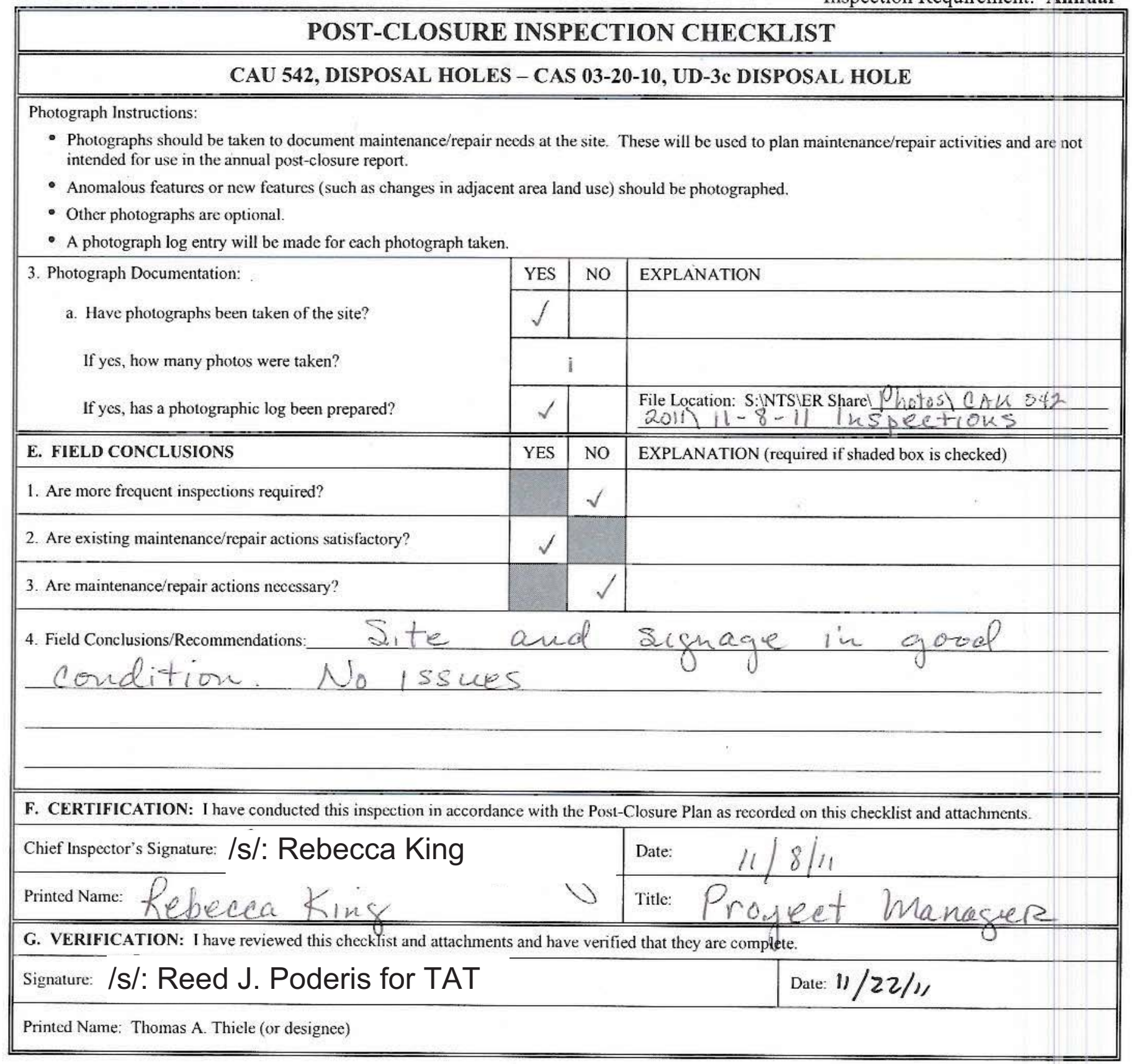




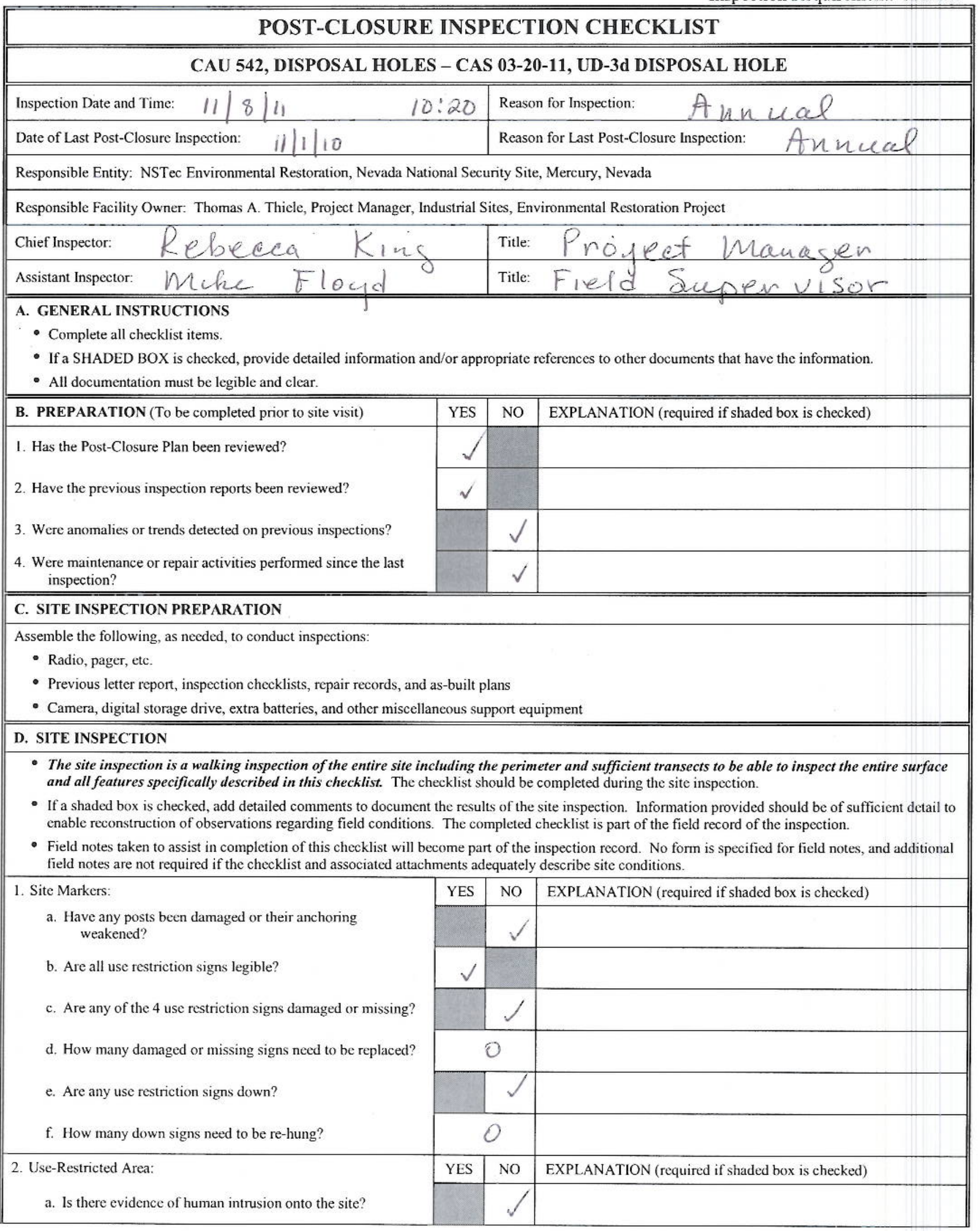




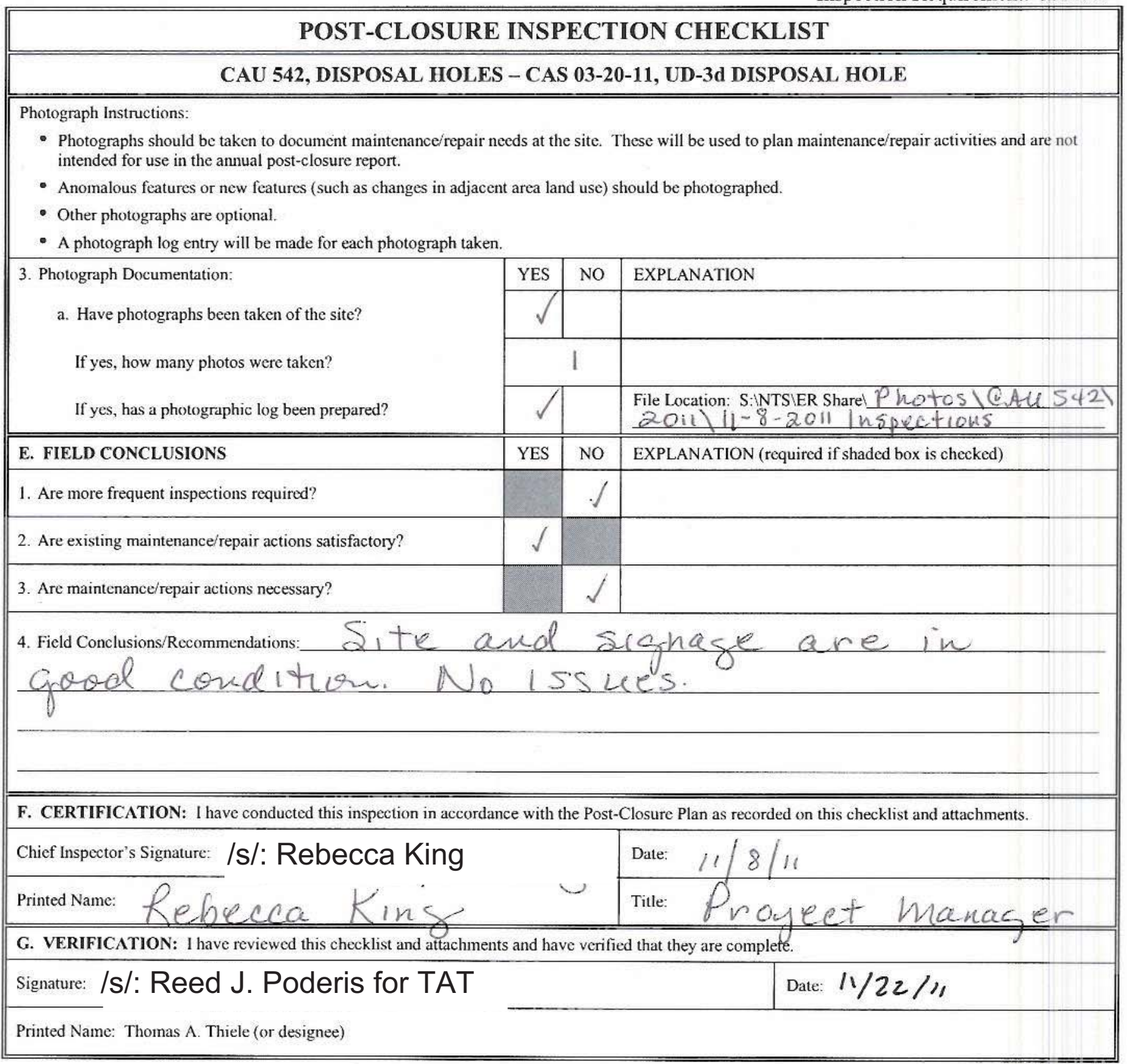


POST-CLOSURE INSPECTION CHECKLIST

\section{CAU 542, DISPOSAL HOLES - CAS 06-20-03, UD-6 AND UD-6s DISPOSAL HOLES}

\begin{tabular}{ll|l|l|}
\hline Inspection Date and Time: & Reason for Inspection: \\
\hline Date of Last Post-Closure Inspection: & Reason for Last Post-Closure Inspection: \\
\hline Responsible Facility Owner: Thomas A. Thiele, Project Manager, Industrial Sites, Environmental Restoration Project \\
Assistant Inspector: \\
A. GENERAL INSTRUCTIONS
\end{tabular}

- Complete all checklist items.

- If a SHADED BOX is checked, provide detailed information and/or appropriate references to other documents that have the information.

- All documentation must be legible and clear.

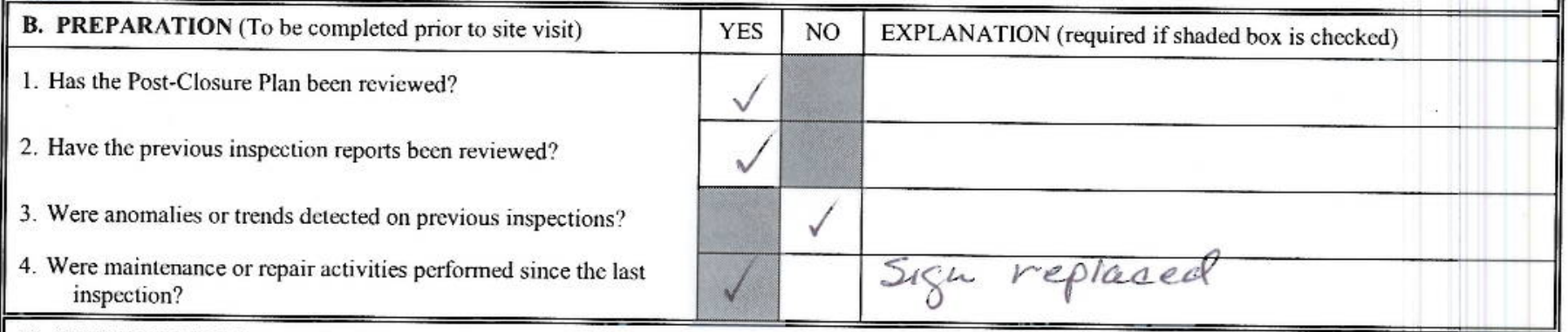

\section{SITE INSPECTION PREPARATION}

Assemble the following, as needed, to conduct inspections:

- Radio, pager, etc.

- Previous letter report, inspection checklists, repair records, and as-built plans

- Camera, digital storage drive, extra batteries, and other miscellaneous support equipment

\section{SITE INSPECTION}

- The site inspection is a walking inspection of the entire site including the perimeter and sufficient transects to be able to inspect the entire surface and all features specifically described in this checklist. The checklist should be completed during the site inspection.

- If a shaded box is checked, add detailed comments to document the results of the site inspection. Information provided should be of sufficient detail to enable reconstruction of observations regarding field conditions. The completed checklist is part of the field record of the inspection.

- Field notes taken to assist in completion of this checklist will become part of the inspection record. No form is specified for field notes, and additional field notes are not required if the checklist and associated attachments adequately describe site conditions.

1. Site Markers:

a. Have any posts been damaged or their anchoring weakened?

b. Are all use restriction signs legible?

c. Are any of the 4 use restriction signs damaged or missing?

d. How many damaged or missing signs need to be replaced?

e. Are any use restriction signs down?

f. How many down signs need to be re-hung?

g. Do any Underground Radioactive Material Area signs need to be replaced or re-hung?

2. Use-Restricted Area:

a. Is there evidence of human intrusion onto the site?

\begin{tabular}{|l|l|l|l|}
\hline YES & NO & EXPLANATION (required if shaded box is checked) \\
\hline & $\checkmark$ & \\
\hline & $\checkmark$ & \\
\hline & & \\
\hline & $\checkmark$ & \\
\hline & & \\
\hline YES & NO & EXPLANATION (required if shaded box is checked) \\
\hline & & \\
\hline
\end{tabular}




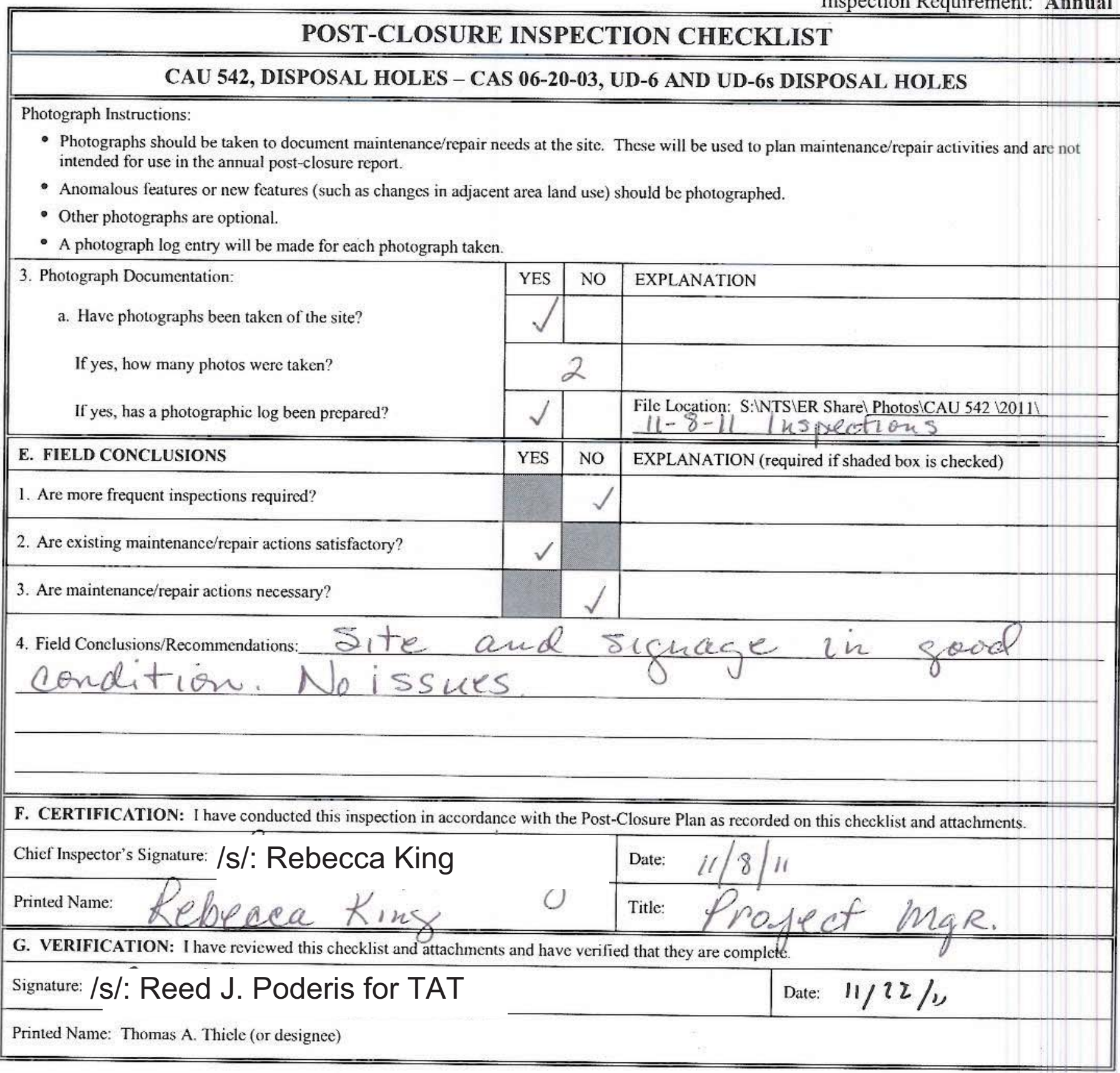


CAU 543: LIQUID DISPOSAL UNITS 
THIS PAGE INTENTIONALLY LEFT BLANK 


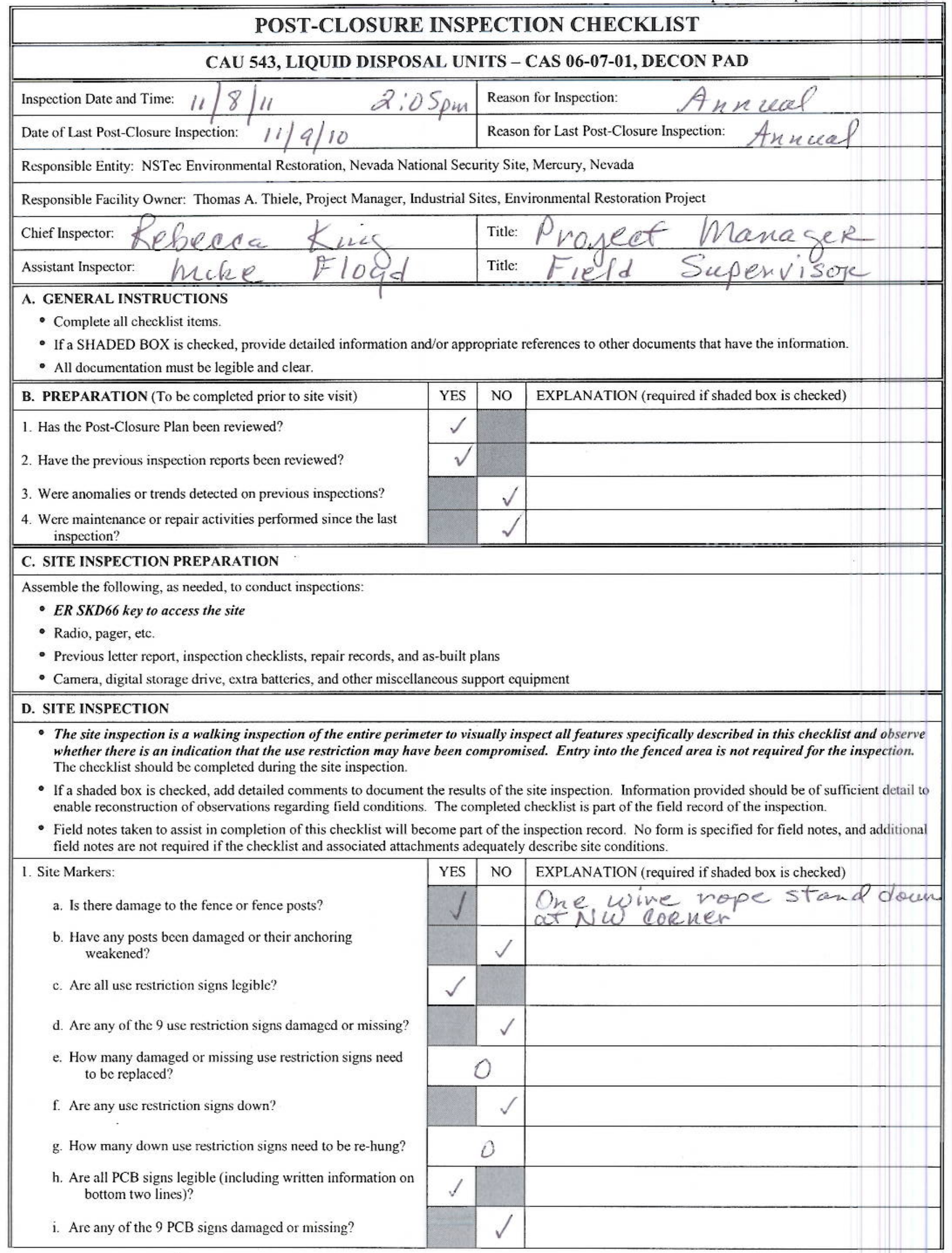




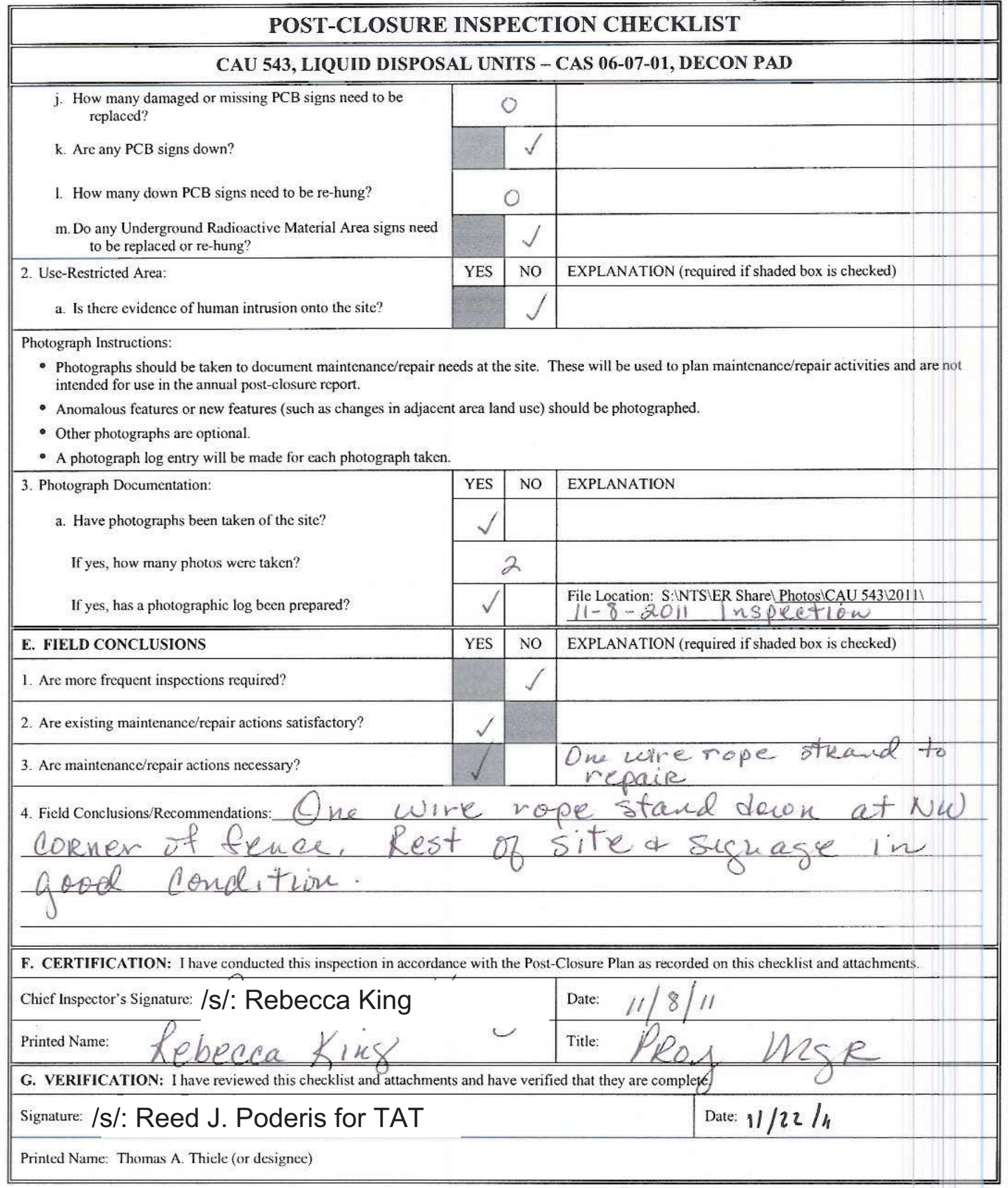




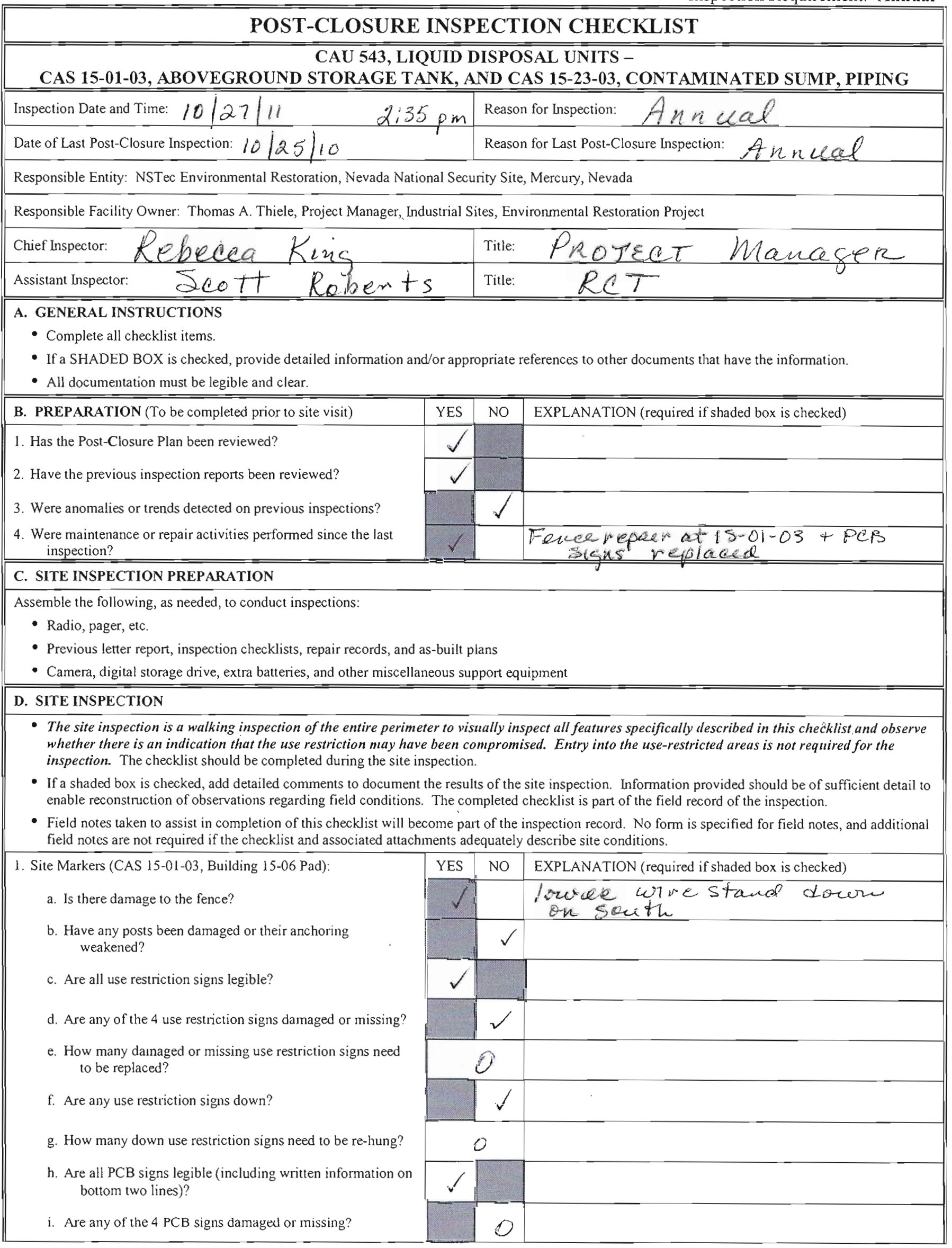




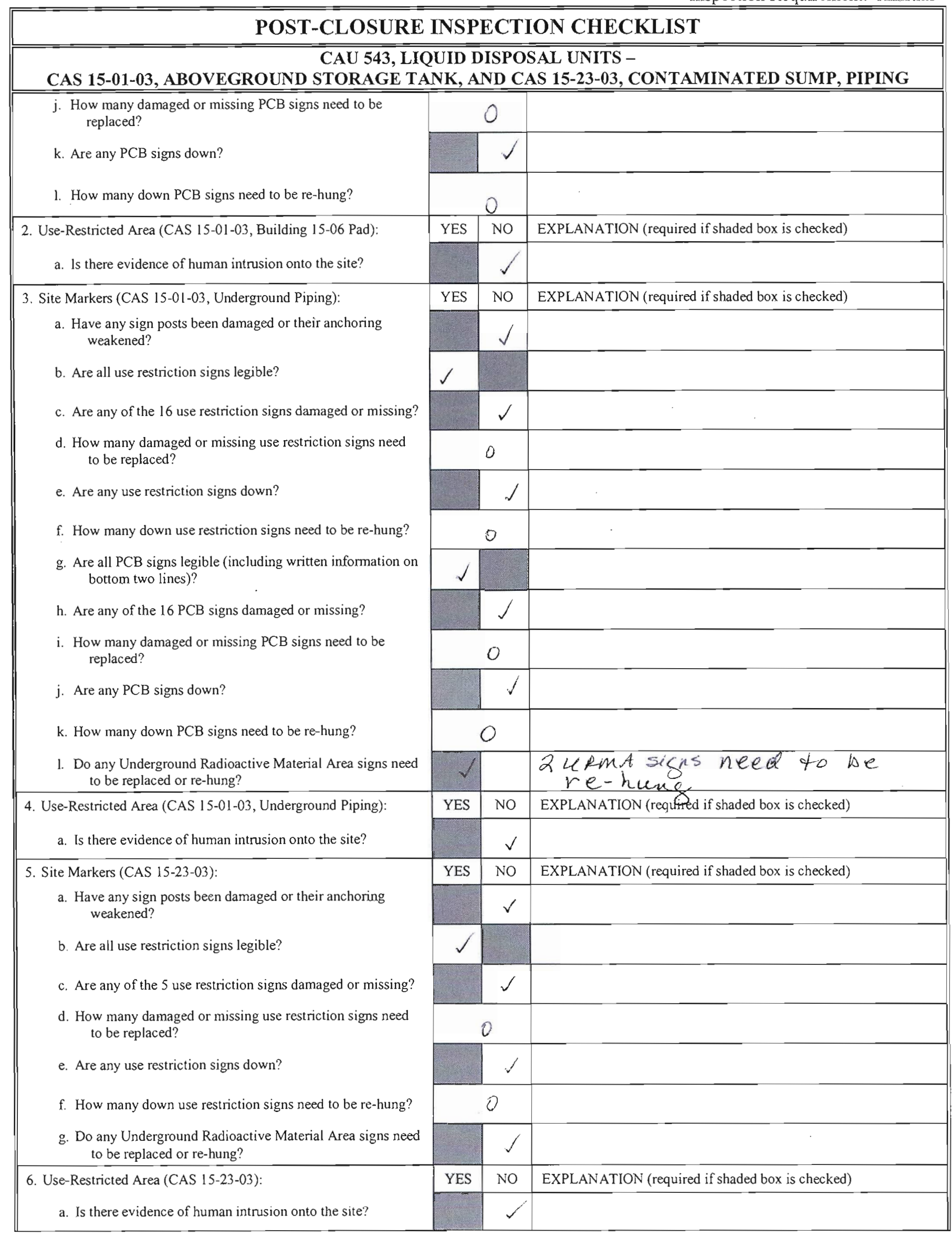




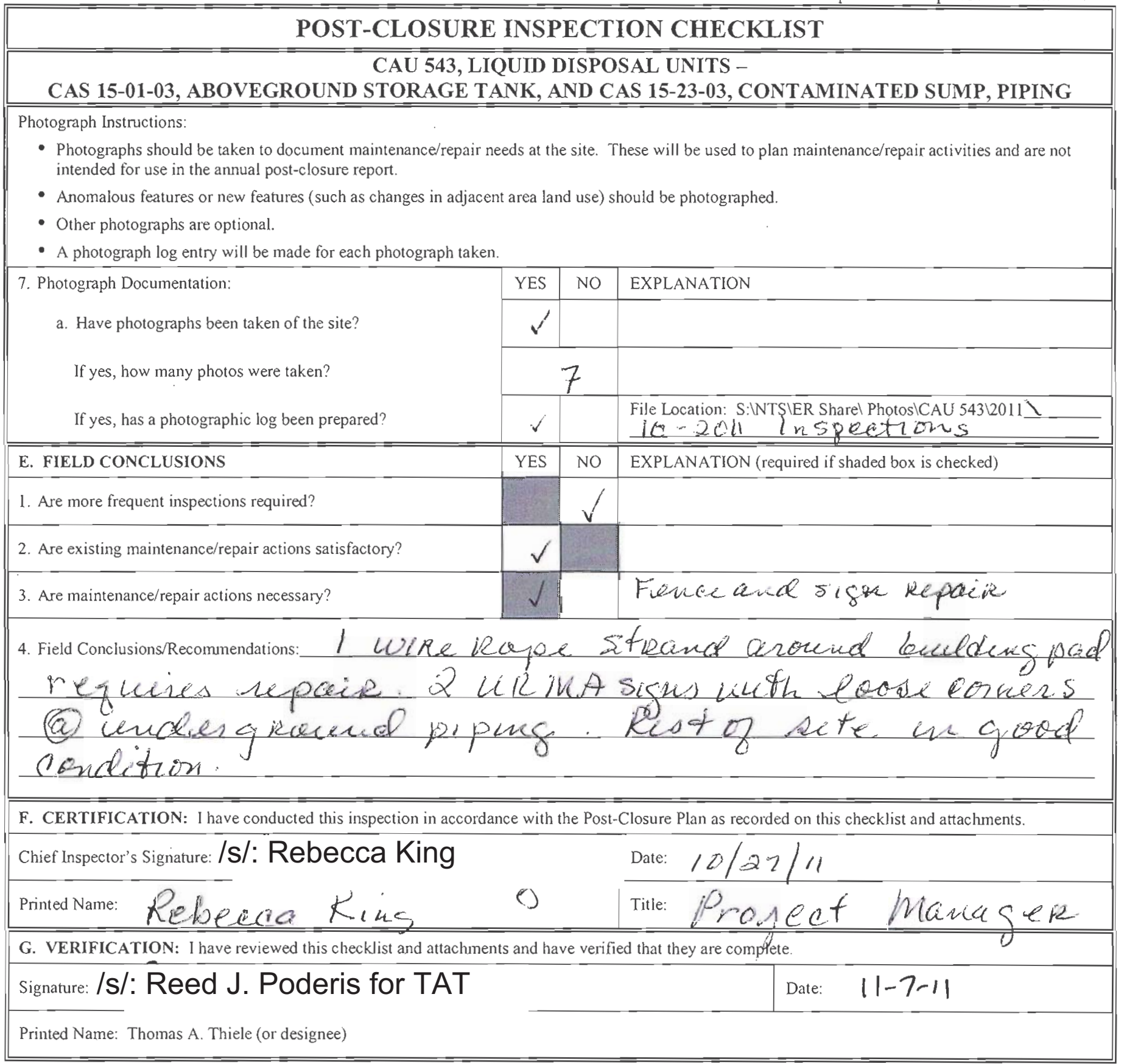


THIS PAGE INTENTIONALLY LEFT BLANK 
CAU 544: CELLARS, MUD PITS, AND OIL SPILLS 
THIS PAGE INTENTIONALLY LEFT BLANK 


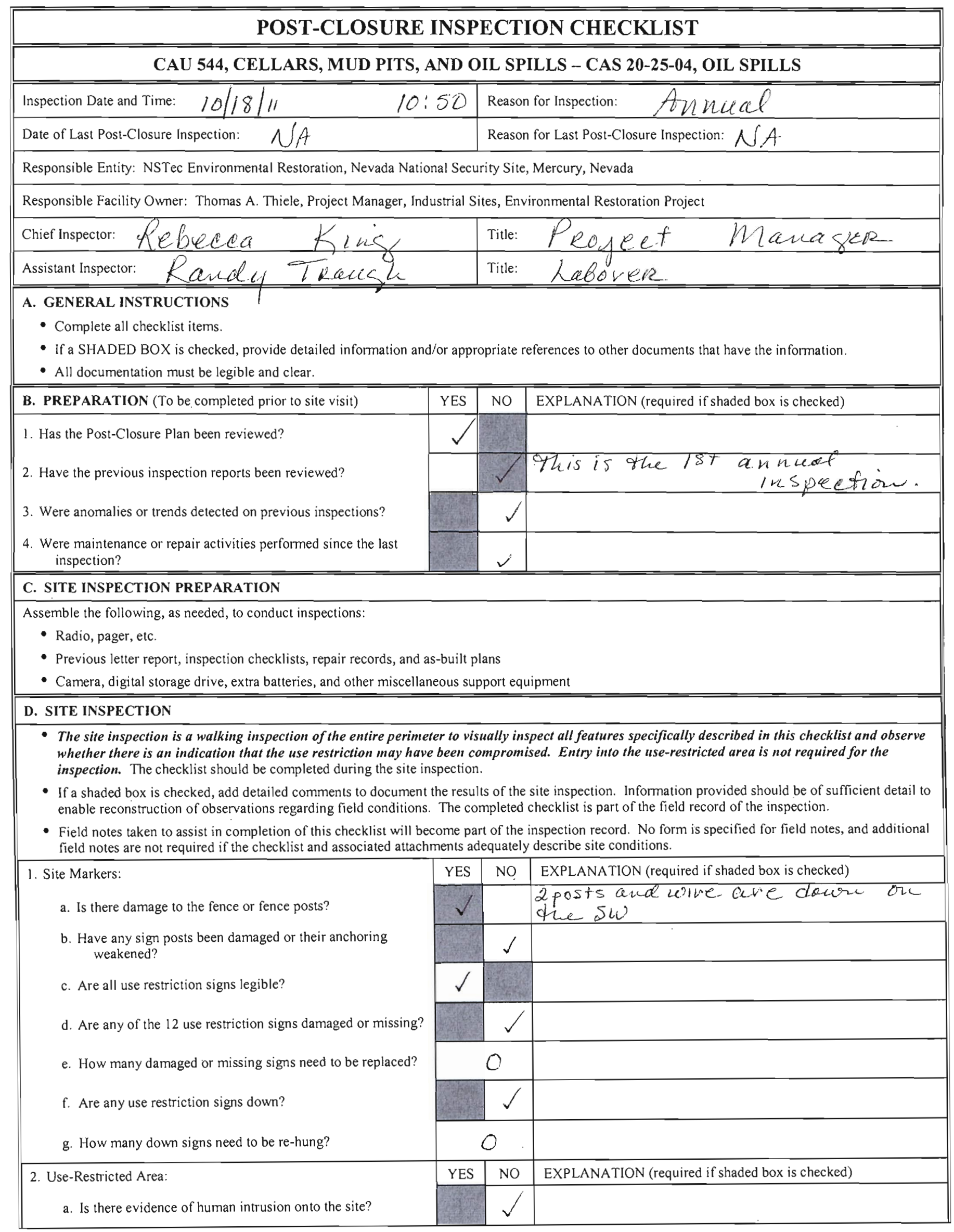

Page 1 of 2 


\section{POST-CLOSURE INSPECTION CHECKLIST}

\section{CAU 544, CELLARS, MUD PITS, AND OUL SPILLS - CAS 20-25-04, OIL SPILLS}

Photograph Instructions:

- Photographs should be taken to document maintenance/repair needs at the site. These will be used to plan maintenance/repair activities and are not intended for use in the annual post-closure report

- Anomalous features or new features (such as changes in adjacent area land use) should be photographed.

- Other photographs are optional.

- A photograph log entry will be made for each photograph taken.

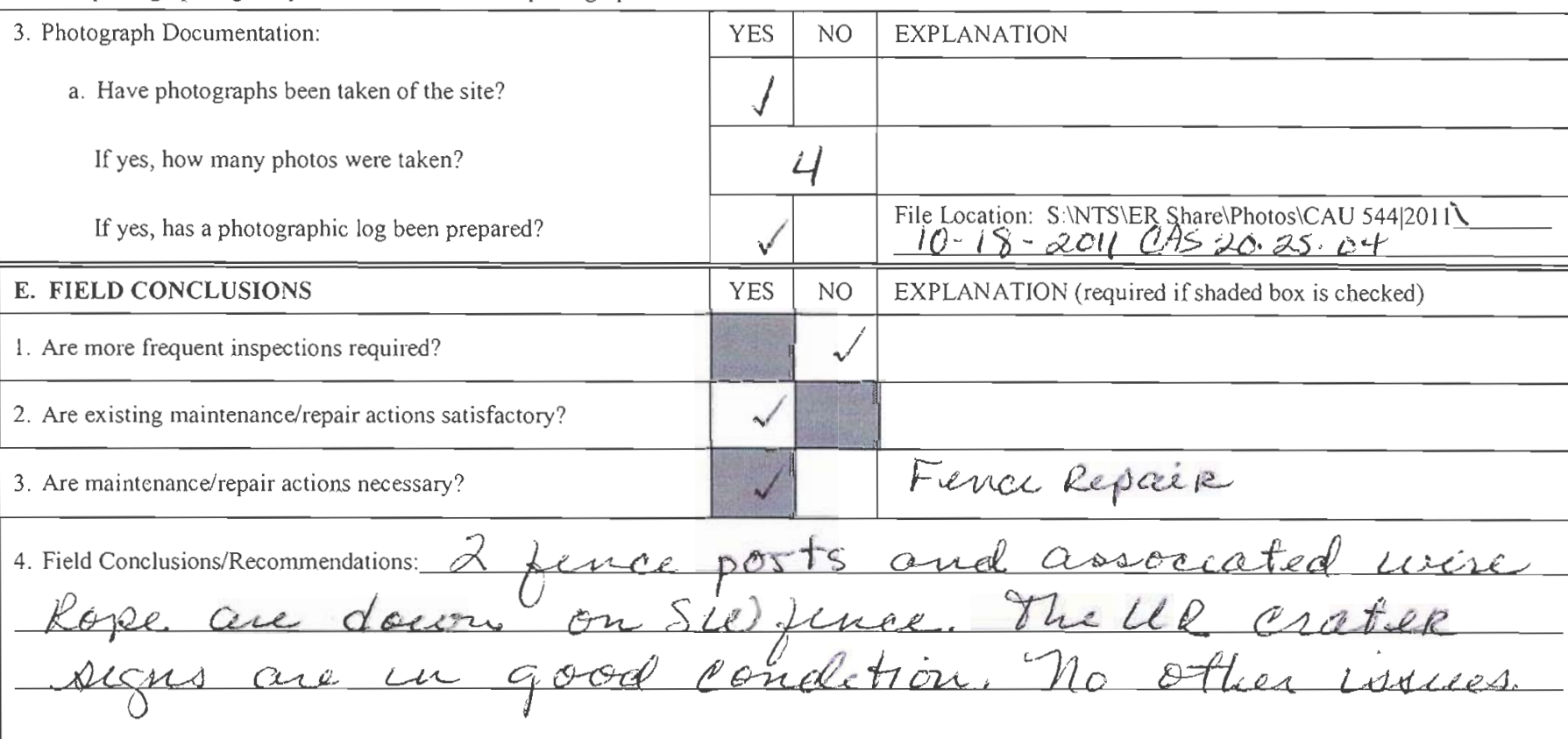

F. CERTIFICATION: I have conducted this inspection in accordance with the Post-Closure Plan as recorded on this checklist and anachments.

Chief Inspector's Signature: /s/: Rebecca King

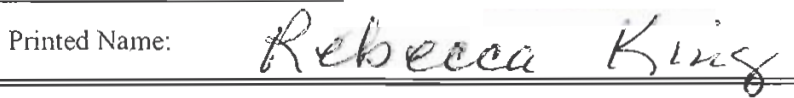

C)
Date: $\quad 10 / 18 / i 1$
Signature: /S/: Reed J. Poderis for TAT $\quad$ Date: $11 / 4 / 2011$

Printed Name: Thomas A. Thiele (or designee) 
CAU 545: DUMPS, WASTE DISPOSAL SITES, AND BURIED RADIOACTIVE MATERIALS 
THIS PAGE INTENTIONALLY LEFT BLANK 
POST-CLOSURE INSPECTION CHECKLIST

\section{CAU 545, DUMPS, WASTE DISPOSAL SITES, AND BURIED RADIOACTIVE MATERIALS -}

CAS 03-08-03, MUD DISPOSAL SITE

\begin{tabular}{|c|c|c|c|}
\hline Inspection Date and Time: 11 & 8111 & $10: 20$ & Reason for Inspection: Annucal \\
\hline Date of Last Post-Closure Inspect & ion: & & Reason for Last Post-Closure Inspection: An uccal \\
\hline
\end{tabular}

Responsible Entity: NSTec Environmental Restoration, Nevada National Security Site, Mercury, Nevada

Responsible Facility Owner: Thomas A. Thiele, Project Manager, Industrial Sites, Environmental Restoration Project

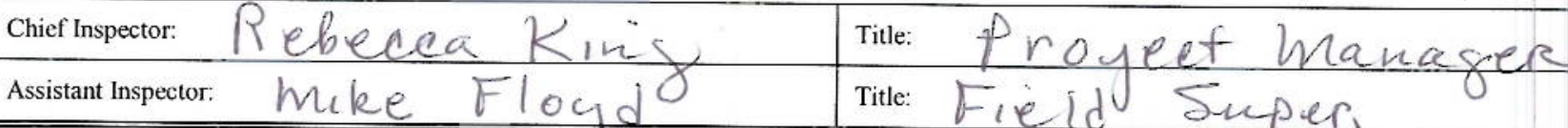

A. GENERAL INSTRUCTIONS

- Complete all checklist items.

- If a SHADED BOX is checked, provide detailed information and/or appropriate references to other documents that have the information.

- All documentation must be legible and clear.

B. PREPARATION (To be completed prior to site visit)

1. Has the Post-Closure Plan been reviewed?

2. Have the previous inspection reports been reviewed?

3. Were anomalies or trends detected on previous inspections?

4. Were maintenance or repair activities performed since the last inspection?

\section{SITE INSPECTION PREPARATION}

Assemble the following, as needed, to conduct inspections:

- Radio, pager, etc.

- Previous letter report, inspection checklists, repair records, and as-built plans

- Camera, digital storage drive, extra batteries, and other miscellaneous support equipment

\section{SITE INSPECTION}

- The site inspection is a walking inspection of the entire perimeter to visually inspect all features specifically described in this checklist and observe whether there is an indication that the use restriction may have been compromised. Entry into the fenced area is not required for the inspection. The checklist should be completed during the site inspection.

- If a shaded box is checked, add detailed comments to document the results of the site inspection. Information provided should be of sufficient detail to enable reconstruction of observations regarding field conditions. The completed checklist is part of the field record of the inspection.

- Field notes taken to assist in completion of this checklist will become part of the inspection record. No fonm is specified for field notes, and additional field notes are not required if the checklist and associated attachments adequately describe site conditions.

1. Site Markers:

a. Is there damage to the fence or fence posts?

b. Have any posts been damaged or their anchoring weakened?

c. Are all use restriction signs legible?

d. Are any of the 14 use restriction signs damaged or missing?

e. How many damaged or missing use restriction signs need to be replaced?

f. Are any use restriction signs down?

g. How many down use restriction signs need to be re-hung?

2. Use-Restricted Area:

a. Is there evidence of human intrusion onto the site?

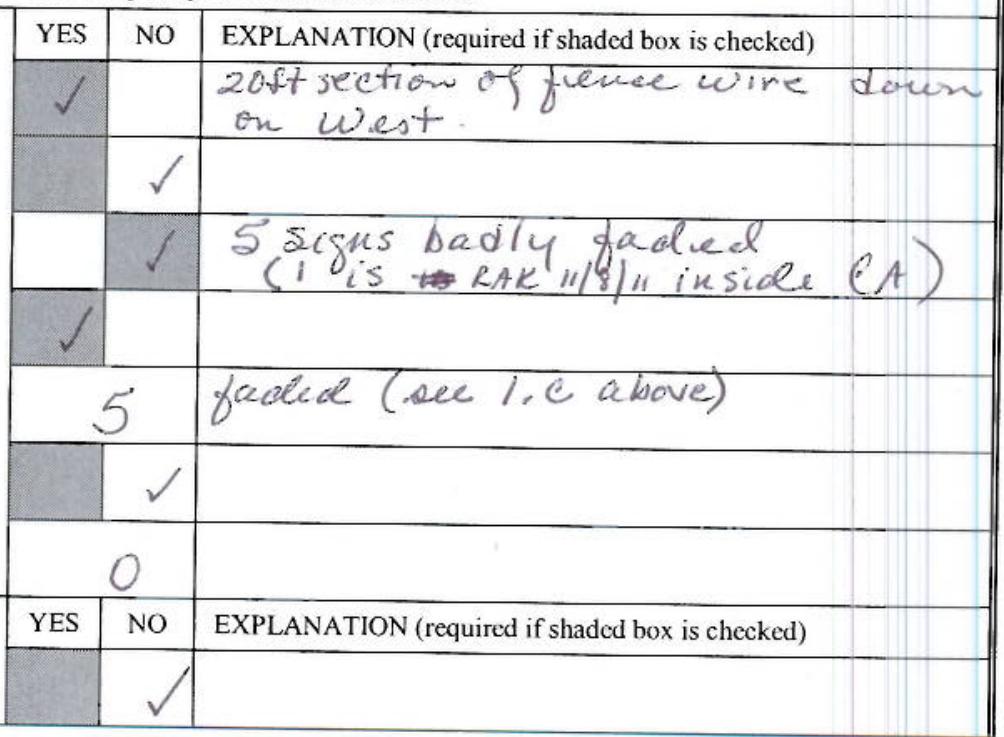




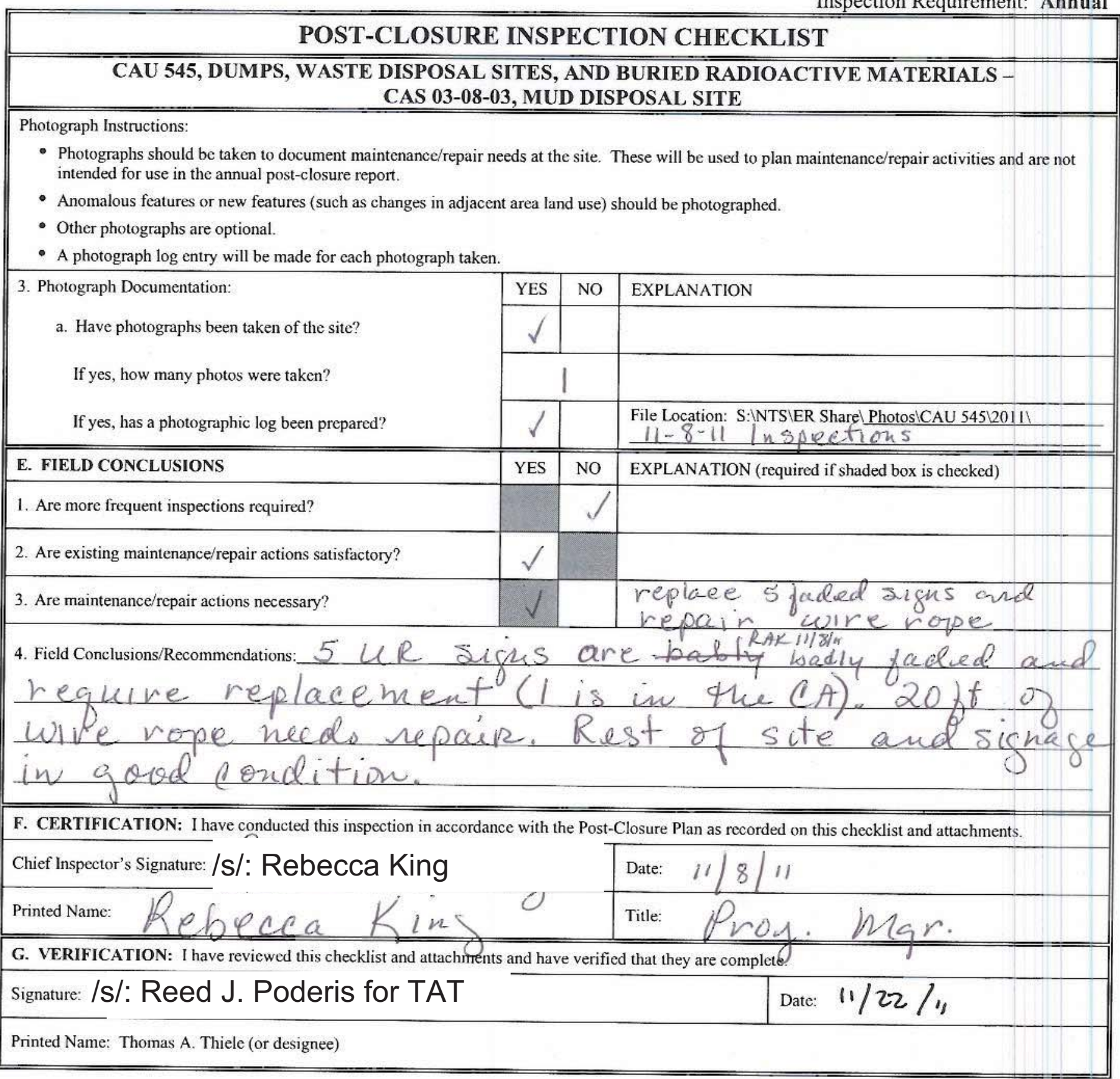




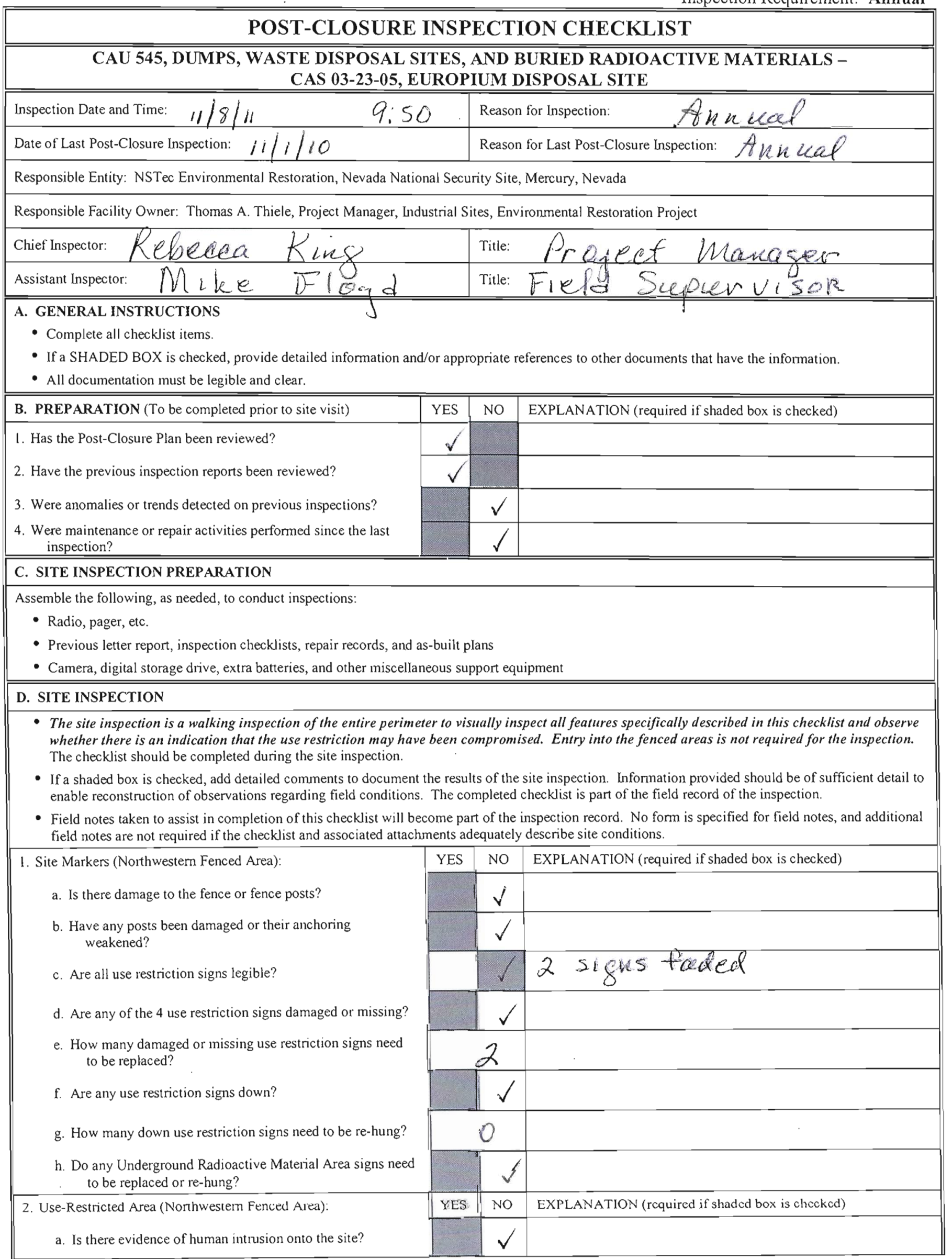




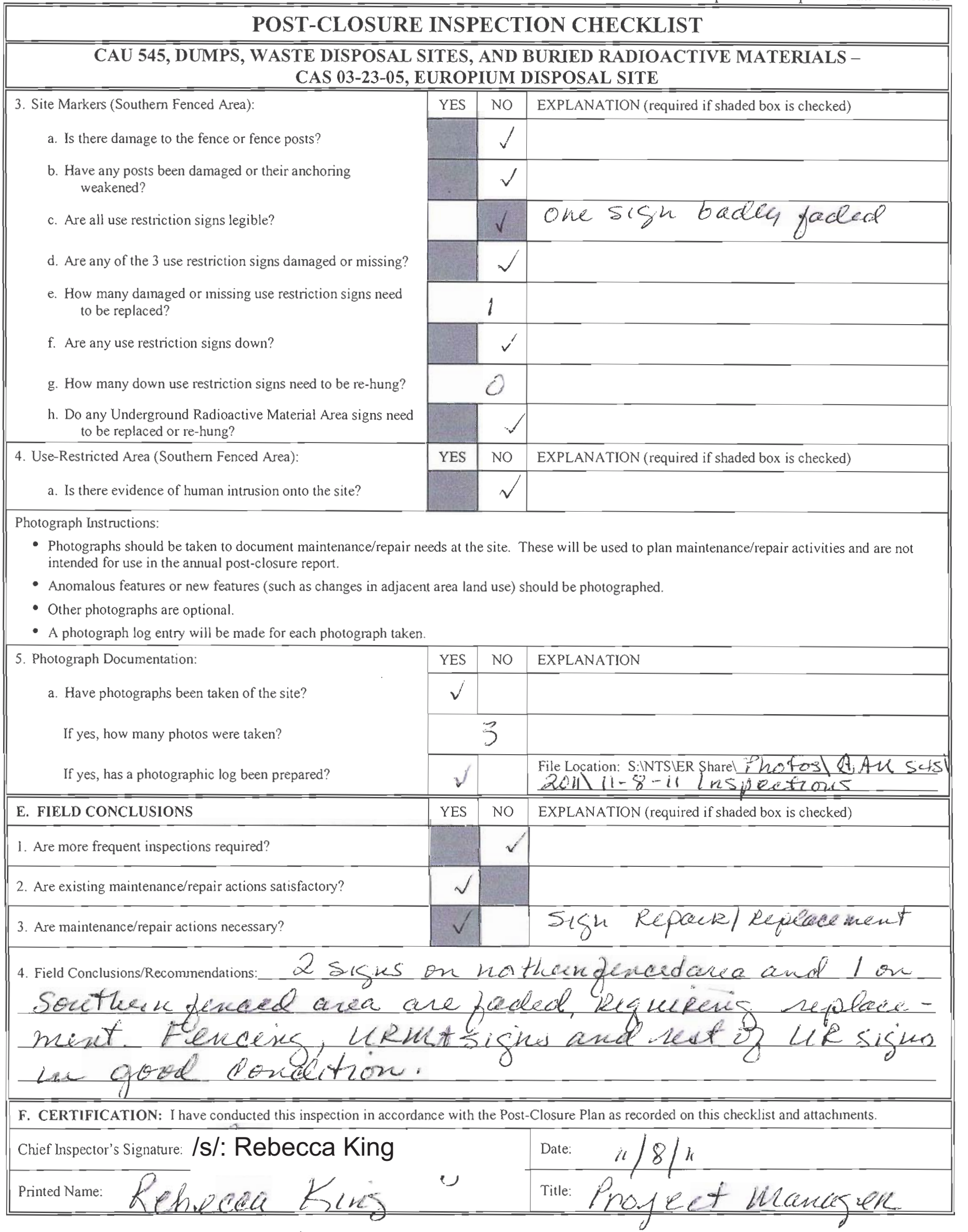


POST-CLOSURE INSPECTION CHECKLIST

CAU 545, DUMPS, WASTE DISPOSAL SITES, AND BURIED RADIOACTIVE MATERIALS CAS 03-23-05, EUROPIUM DISPOSAL SITE

G. VERIFICATION: $I$ have reviewed this checklist and attachments and have verified that they are complete.

Signature: /s/: Reed J. Poderis for TAT

Date: $1 / 22 / 1$

Printed Name: Thomas A. Thiele (or designee) 
THIS PAGE INTENTIONALLY LEFT BLANK 
CAU 546: INJECTION WELL AND SURFACE RELEASES 
THIS PAGE INTENTIONALLY LEFT BLANK 
POST-CLOSURE INSPECTION CHECKLIST

\section{CAU 546, IN.JECTION WELL AND SURFACE RELEASES - CAS 09-20-01, INJECTION WELL}

\begin{tabular}{|c|c|}
\hline Inspection Date and Time: $10 / 27 / 11 \quad 3: 45 \mathrm{pm}$ & Reason for Inspection: Axuclal \\
\hline Date of Last Post-Closure Inspection: $\quad \wedge A$ & Reason for Last Post-Closure Inspection: Ath \\
\hline \multicolumn{2}{|c|}{ Responsible Entity: NSTec Environmental Restoration, Nevada National Security Site, Mercury, Nevada } \\
\hline \multicolumn{2}{|c|}{ Responsible Facility Owner: Thomas A. Thiele, Project Manager, Industrial Sites, Environmental Restoration Project } \\
\hline Chief Inspector: $\quad$ e beeca & Title: Po.lef Mlan \\
\hline Assistant Inspector: & Title: \\
\hline
\end{tabular}

A. GENERAL INSTRUCTIONS

- Complete all checklist items.

- If a SHADED BOX is checked, provide detailed information and/or appropriate references to other documents that have the information.

- All documentation must be legible and clear.
B. PREPARATION (To be completed prior to site visit)

1. Has the Post-Closure Plan been reviewed?

2. Have the previous inspection reports been reviewed?

3. Were anomalies or trends detected on previous inspections?

4. Were maintenance or repair activities performed since the last inspection?

\section{SITE INSPECTION PREPARATION}

Assemble the following, as needed, to conduct inspections:

- Radio, pager, etc.

- Previous letter report, inspection checklists, repair records, and as-built plans

- Camera, digital storage drive, extra batteries, and other miscellaneous support equipment

\section{SITE INSPECTION}

- The site inspection is a walking inspection of the entire site including the perimeter and sufficient transects to be able to inspect the entire surface and all features specifically described in this checklist. The checklist should be completed during the site inspection.

- If a shaded box is checked, add detailed comments to document the results of the site inspection. Information provided should be of sufficient detail to enable reconstruction of observations regarding field conditions. The completed checklist is part of the field record of the inspection.

- Field notes taken to assist in completion of this checklist will become part of the inspection record. No form is specified for field notes, and additional field notes are not required if the checklist and associated attachments adequately describe site conditions.

1. Site Markers:

a. Have any posts been damaged or their anchoring weakened?

b. Are all use restriction signs legible?

c. Are any of the 4 use restriction signs damaged or missing?

d. How many damaged or missing signs need to be replaced?

e. Are any use restriction signs down?

f. How many down signs need to be re-hung?

2. Use-Restricted Area:

a. Is there evidence of human intrusion onto the site?

\begin{tabular}{|c|c|l||}
\hline YES & NO & EXPLANATION (required if shaded box is checked) \\
\hline & $\sqrt{ }$ & \\
\hline & & \\
\hline & $\checkmark$ & \\
\hline & & \\
\hline & & \\
\hline & & \\
\hline & & \\
\hline YES & NO & EXPLANATION (required if shaded box is checked) \\
\hline & $/$ & \\
\hline
\end{tabular}




\section{POST-CLOSURE INSPECTION CHECKLIST}

\section{CAU 546, INJECTION WELL AND SURFACE RELEASES - CAS 09-20-01, INJECTION WELL}

Photograph Instructions:

- Photographs should be taken to document maintenance/repair needs at the site. These will be used to plan maintenance/repair activities and are not intended for use in the annual post-closure report.

- Anomalous features or new features (such as changes in adjacent area land use) should be photographed.

- Other photographs are optional.

- A photograph log entry will be made for each photograph taken.

3. Photograph Documentation:

a. Have photographs been taken of the site?

If yes, how many photos were taken?

If yes, has a photographic log been prepared?

\section{E. FIELD CONCLUSIONS}

1. Are more frequent inspections required?

2. Are existing maintenance/repair actions satisfactory?

3. Are maintenance/repair actions necessary?

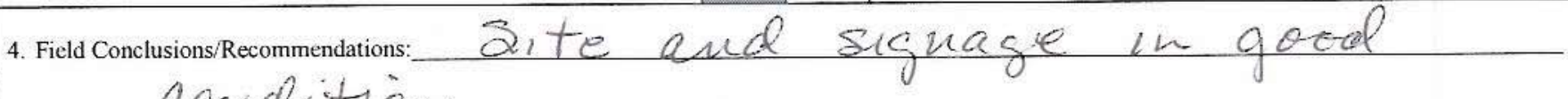

$$
\text { AQrali itar }
$$

F. CERTIFICATION: I have conducted this inspection in accordance with the Post-Closure Plan as recorded on this checklist and attachments.

Chief Inspector's signature: /s/: Rebecca King

Printed Name:

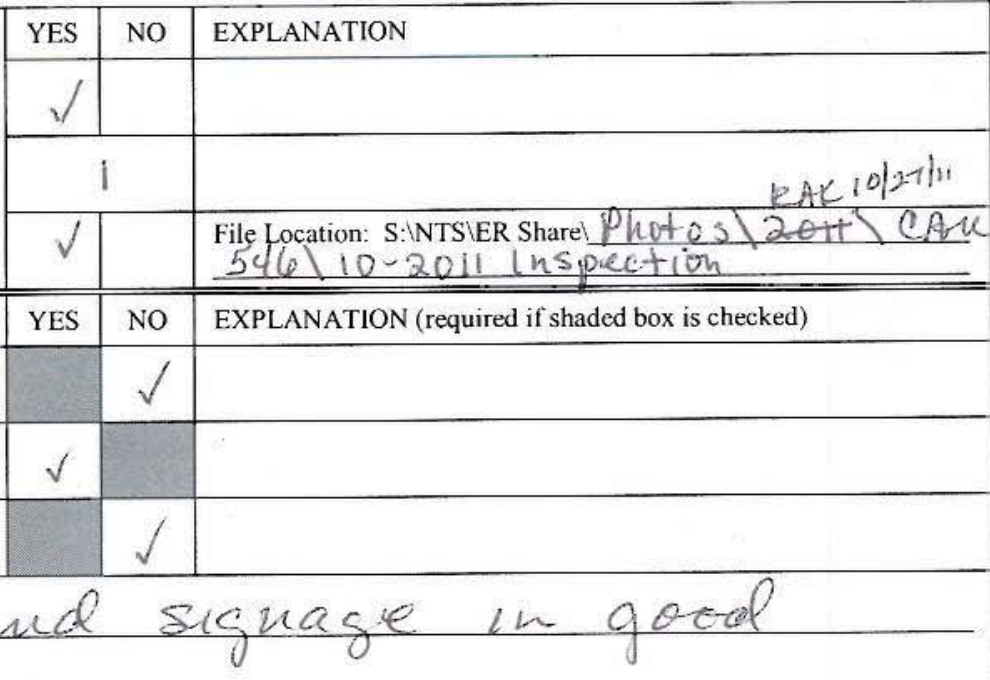

G. VERIFICATION: I have reviewed this checklist and attachments and have verified that they are complete.

Signature: $/ \mathrm{s} /:$ Reed $\mathrm{J}$. Poderis for TAT

Date: $11 / 7 / 11$

Printed Name: Thomas A. Thicle (or designee) 
CAU 551: AREA 12 MUCKPILES 
THIS PAGE INTENTIONALLY LEFT BLANK 


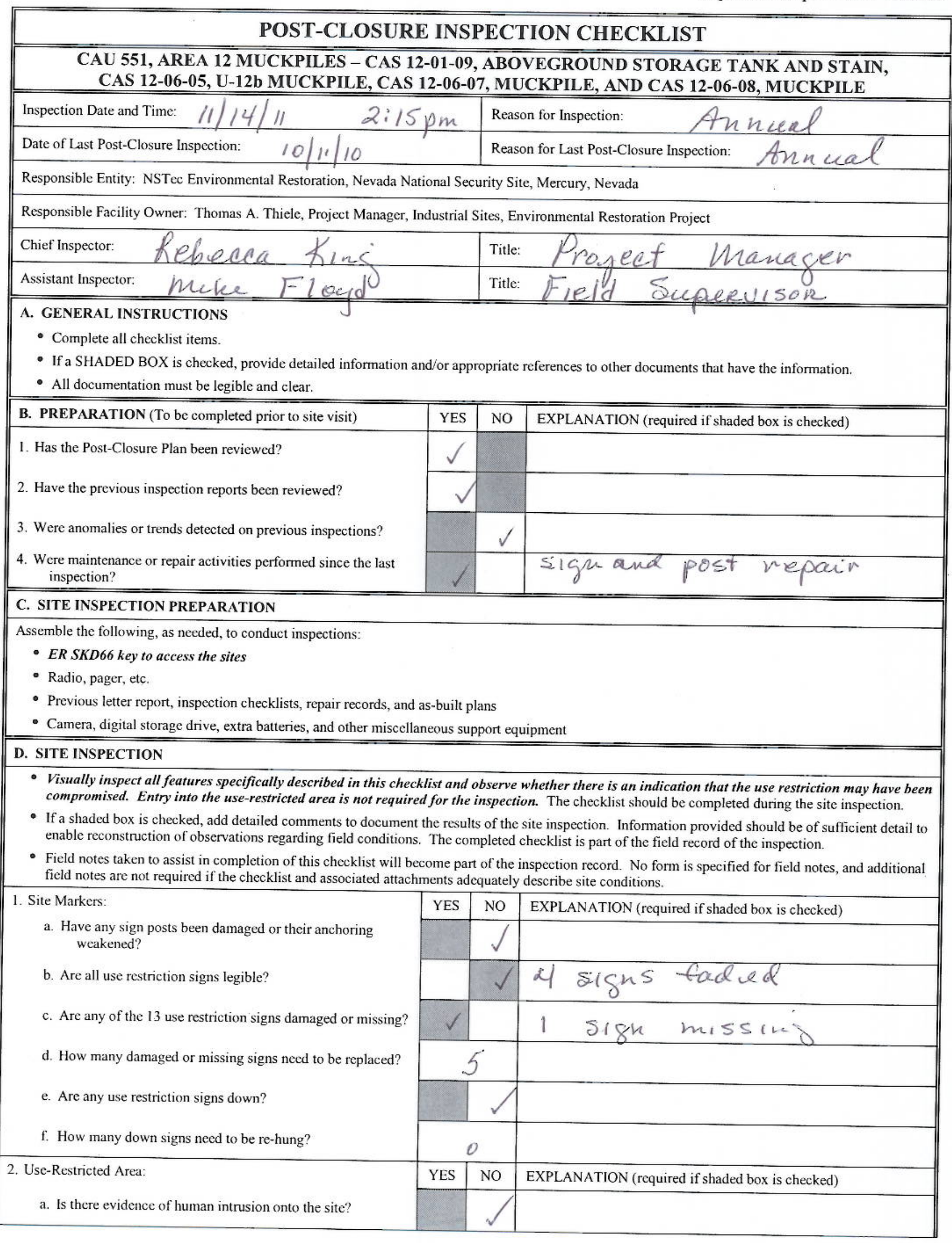


POST-CLOSURE INSPECTION CHECKLIST

\section{CAU 551, AREA 12 MUCKPILES - CAS 12-01-09, ABOVEGROUND STORAGE TANK AND STAIN, CAS 12-06-05, U-12b MUCKPILE, CAS 12-06-07, MUCKPILE, AND CAS 12-06-08, MUCKPILE}

3. Adjacent Offsite Features:

a. Are both runoff diversion berms in place and functioning as designed?

b. Is there evidence of erosion (wind or water) or other damage to the berms?

c. Is there evidence of sediment migrating past the E-Tunnel tumoff culvert or across the access road?

d. Is there evidence of erosion (wind or water) or other damage to the E-Tunnel turnoff culvert or access road?

Photograph Instructions:

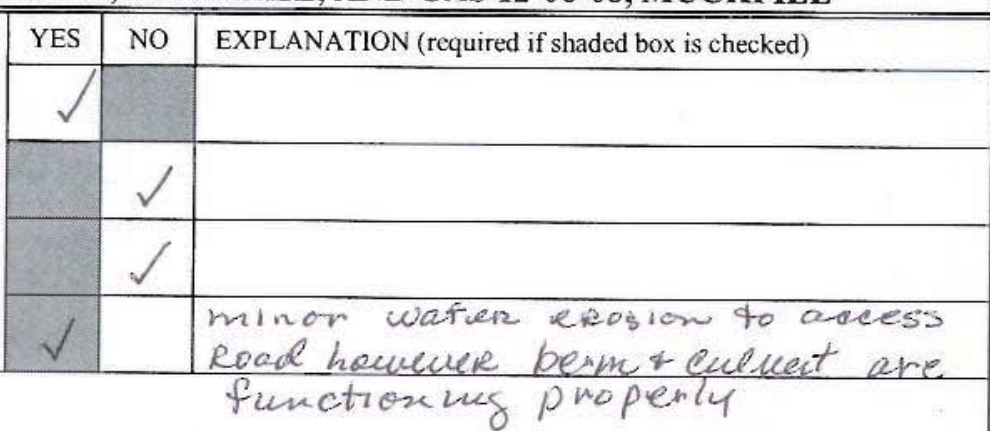

- Photographs are REQUIRED to document whether there is visible evidence of sediment migrating past the E-Tunnel turnoff culvert.

- Anomalous features or new features (such as changes in adjacent area land use) should be photographed.

- Other photographs are optional.

- A photograph log entry will be made for each photograph taken.

4. Photograph Documentation:

a. Have photographs been taken of the site?

If yes, how many photos were taken?

If yes, has a photographic $\log$ been prepared?

\begin{tabular}{||l|l|}
\hline \hline E. FIELD CONCLUSIONS & YE \\
\hline 1. Are more frequent inspections required? & \\
\hline 2. Are existing maintenance/repair actions satisfactory? & \\
\hline 3. Are maintenance/repair actions necessary? & \\
\hline
\end{tabular}

\begin{tabular}{|c|c|}
\hline \begin{tabular}{l|l} 
YES & P \\
\end{tabular} & \\
\hline$\sqrt{ }$ & \\
\hline 5 & \\
\hline$\checkmark$ & \\
\hline YES & \\
\hline & \\
\hline$\sqrt{ }$ & \\
\hline & \\
\hline$\checkmark$ & \\
\hline
\end{tabular}

File Location: S:INTS $\backslash$ ER SharelPhotosiCAU 55112011

$11-14-2011$ Inspertiox

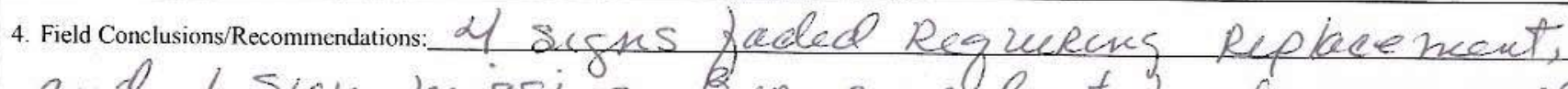

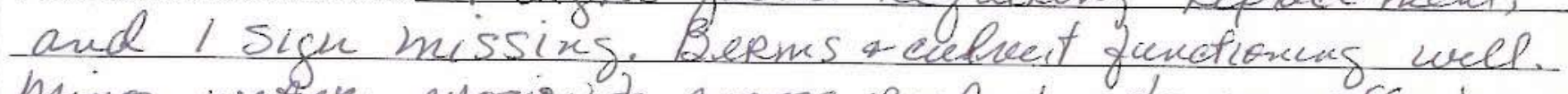
Minor watiere ekosion to aeerss kaced due to rue off down

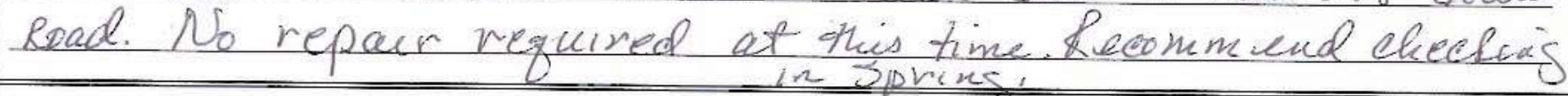

F. CERTIFICATION: I have conducted this inspection in accordance with the Post-Closure Plan as recorded on this checklist and attachments.

Chief Inspector's Signature: /s/: Rebecca King

Printed Name:
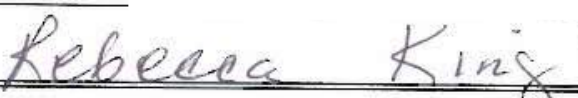

Date: $1 / / 4 / 11$

G. VERIFICATION: I have reviewed this checklist and attachments and have verified that they are complete.

Signature: /s/: Reed J.Poderis for TAT

Printed Name: Thomas A. Thiele (or designee) 
CAU 552: AREA 12 MUCKPILE AND PONDS 
THIS PAGE INTENTIONALLY LEFT BLANK 


\section{POST-CLOSURE INSPECTION CHECKLIST}

\section{CAU 552, AREA 12 MUCKPILE AND PONDS - CAS 12-23-05, PONDS}

\begin{tabular}{|c|c|c|c|}
\hline \multicolumn{2}{|c|}{ Inspection Date and Time: $10 / 18 / 11 \quad 1420$} & \multicolumn{2}{|c|}{ Reason for lnspection: $\quad A n n c c a l$} \\
\hline \multicolumn{2}{|c|}{ Date of Last Post-Closure Inspection: $10 / 11 / 10$} & \multicolumn{2}{|c|}{ Reason for Last Post-Closure Inspection: $A \mathrm{~A} \mathrm{nLCl}$} \\
\hline \multicolumn{4}{|c|}{ Responsible Entity: NSTec Environmental Restoration, Nevada National Security Site, Mercury, Nevada } \\
\hline \multicolumn{4}{|c|}{ Responsible Facility Owner: Thomas A. Thiele, Project Manager, Industrial Sites, Environmental Restoration Project } \\
\hline \multicolumn{2}{|l|}{ Chief Inspector: } & \multicolumn{2}{|c|}{ 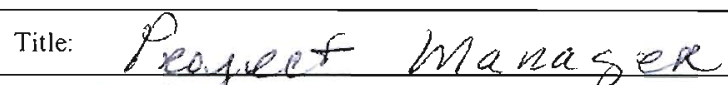 } \\
\hline \multicolumn{2}{|l|}{ Assistant Inspector: $\quad$ Xandend Thesech } & \multicolumn{2}{|c|}{ Title: 1 afpren } \\
\hline \multicolumn{4}{|c|}{$\begin{array}{l}\text { A. GENERAL INSTRUCTIONS } \\
\text { - Complete all checklist items. } \\
\text { - If a SHADED BOX is checked, provide detailed information and/or appropriate references to other documents that have the information. } \\
\text { - All documentation must be legible and clear. }\end{array}$} \\
\hline B. PREPARATION (To be completed prior to site visit) & YES & NO & EXPLANATION (required if shaded box is checked) \\
\hline \multicolumn{4}{|l|}{ 1. Has the Post-Closure Plan been reviewed? } \\
\hline \multicolumn{4}{|l|}{ 2. Have the previous inspection reports been reviewed? } \\
\hline \multicolumn{4}{|l|}{ 3. Were anomalies or trends detected on previous inspections? } \\
\hline \multicolumn{2}{|l|}{$\begin{array}{l}\text { 4. Were maintenance or repair activities performed since the last } \\
\text { inspection? }\end{array}$} & & 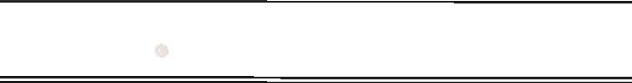 \\
\hline \multicolumn{4}{|l|}{ C. SITE INSPECTION PREPARATION } \\
\hline \multicolumn{4}{|c|}{$\begin{array}{l}\text { Assemble the following, as needed, to conduct inspections: } \\
\text { - Radio, pager, etc. } \\
\text { - Previous letter report, inspection checklists, repair records, and as-built plans } \\
\text { - Camera, digital storage drive, extra batteries, and other miscellaneous support equipment }\end{array}$} \\
\hline
\end{tabular}

\section{SITE INSPECTION}

\section{- Check in at the G-Tunnel office prior to the inspection.}

- Visually inspect all features specifically described in this checklist and observe whether there is an indication that the use restriction may have been compromised. Entry into the use-restricted area is not required for the inspection. The checklist should be completed during the site inspection.

- If a shaded box is checked, add detailed comments to document the results of the site inspection. Information provided should be of sufficient detail to enable reconstruction of observations regarding field conditions. The completed checklist is part of the field record of the inspection.

- Field notes taken to assist in completion of this checklist will become part of the inspection record. No form is specified for field notes, and additional field notes are not required if the checklist and associated attachments adequately describe site conditions.

1. Site Markers:

a. Is there damage to the fence?

b. Have any posts been damaged or their anchoring weakened?

c. Are all use restriction signs legible?

d. Are any use restriction signs damaged or missing?

e. How many damaged or missing signs need to be replaced?

f. Are any use restriction signs down?

g. How many down signs need to be re-hung?

h. Do any Radioactive Material Area signs need to be replaced or re-hung?

\begin{tabular}{|c|c|c|}
\hline YES & NO & EXPLANATION (required if shaded box is checked) \\
\hline & $\checkmark$ & \\
\hline & $\checkmark$ & \\
\hline$\checkmark$ & & \\
\hline$\checkmark$ & & sign has a loose coenex \\
\hline & & \\
\hline & $\checkmark$ & \\
\hline & \\
\hline & $\checkmark$ \\
\hline
\end{tabular}




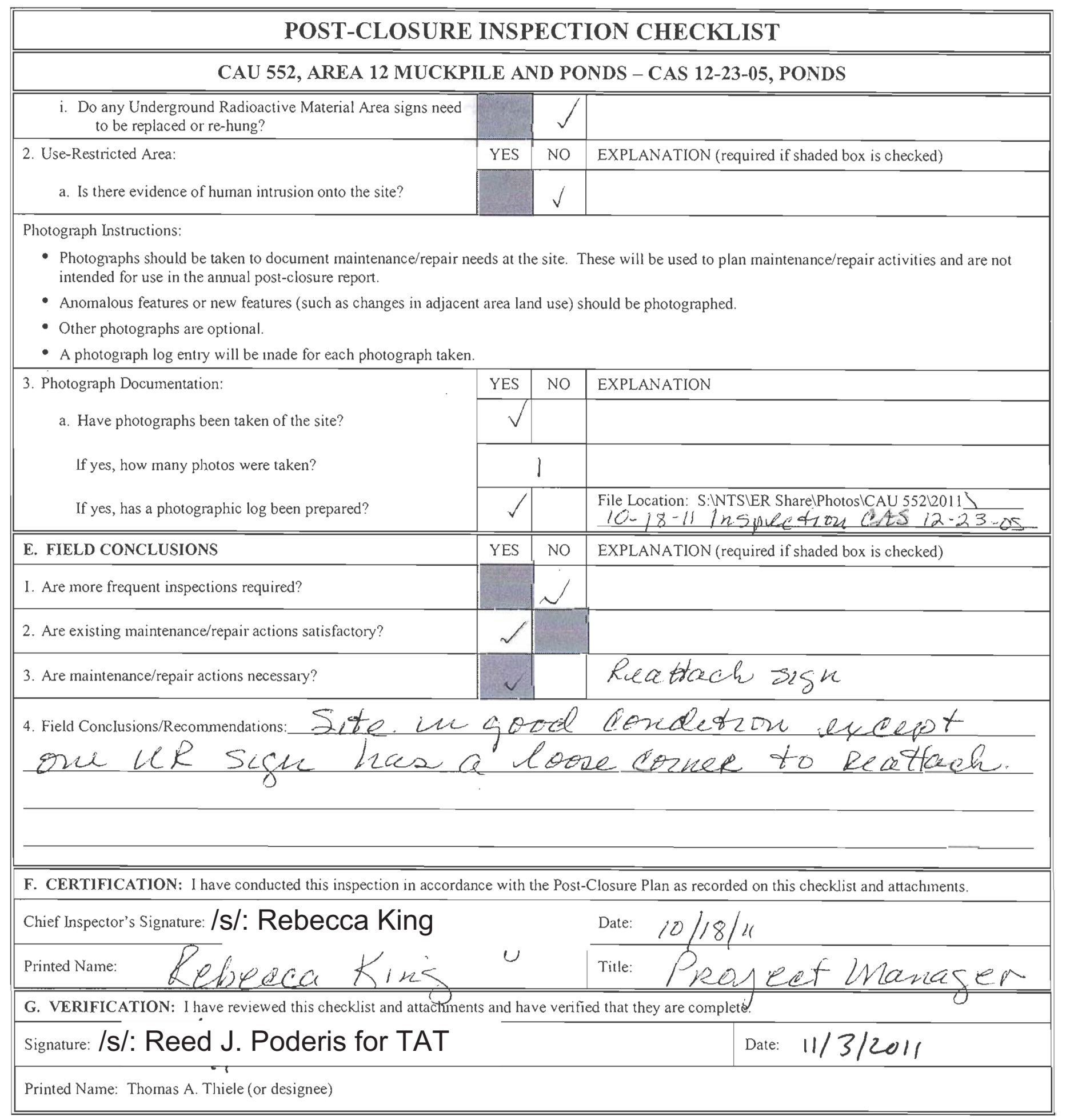


CAU 554: AREA 23 RELEASE SITE 
THIS PAGE INTENTIONALLY LEFT BLANK 


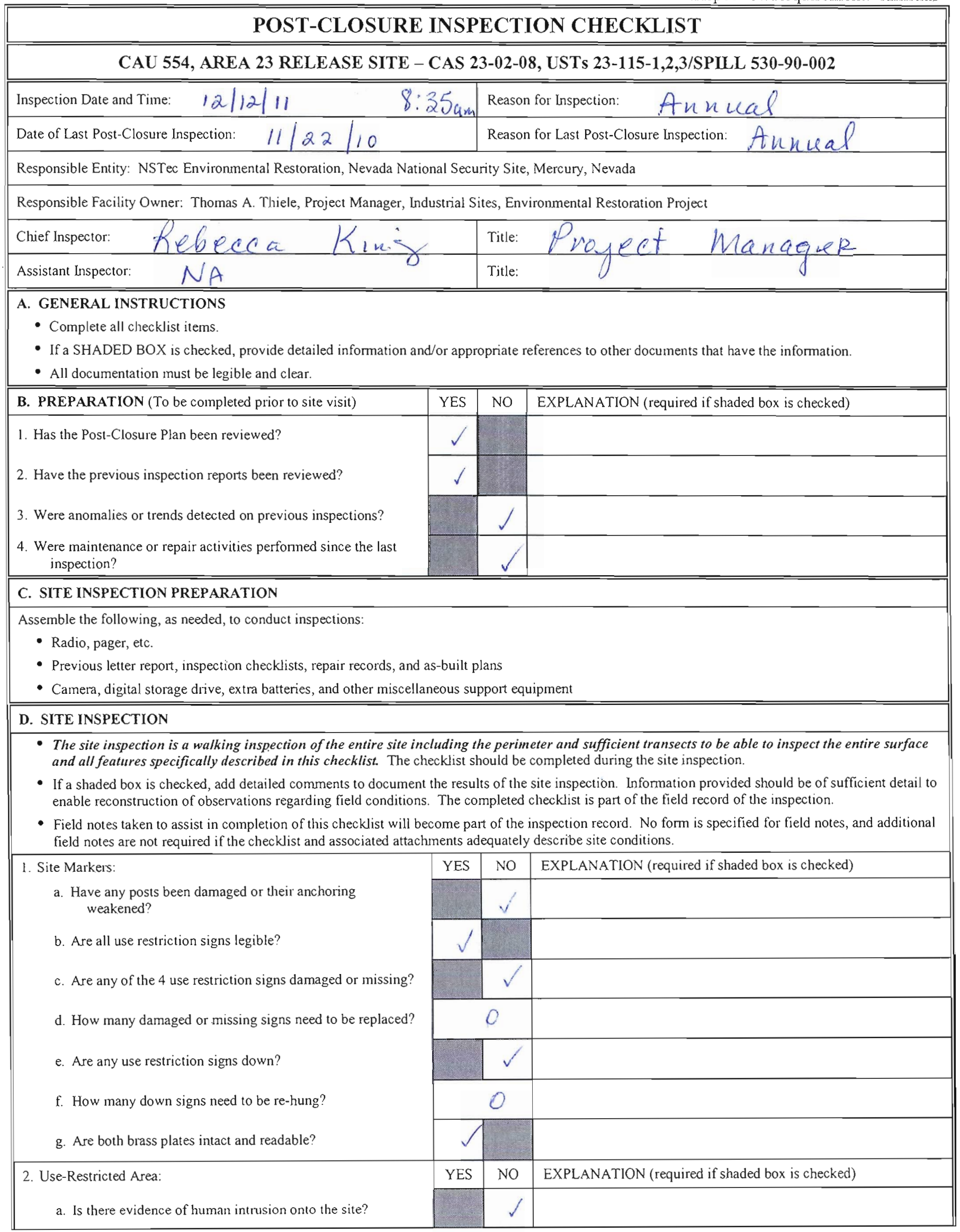


POST-CLOSURE INSPECTION CHECKLIST

\section{CAU 554, AREA 23 RELEASE SITE - CAS 23-02-08, USTs 23-115-1,2,3/SPILL 530-90-002}

Photograph Instructions:

- Photographs should be taken to document maintenance/repair needs at the site. These will be used to plan maintenance/repair activities and are not intended for use in the annual post-closure report.

- Anomalous features or new features (such as changes in adjacent area land use) should be photographed.

- Other photographs are optional.

- A photograph log entry will be made for each photograph taken.

3. Photograph Documentation:

a. Have photographs been taken of the site?

If yes, how many photos were taken?

If yes, has a photographic log been prepared?

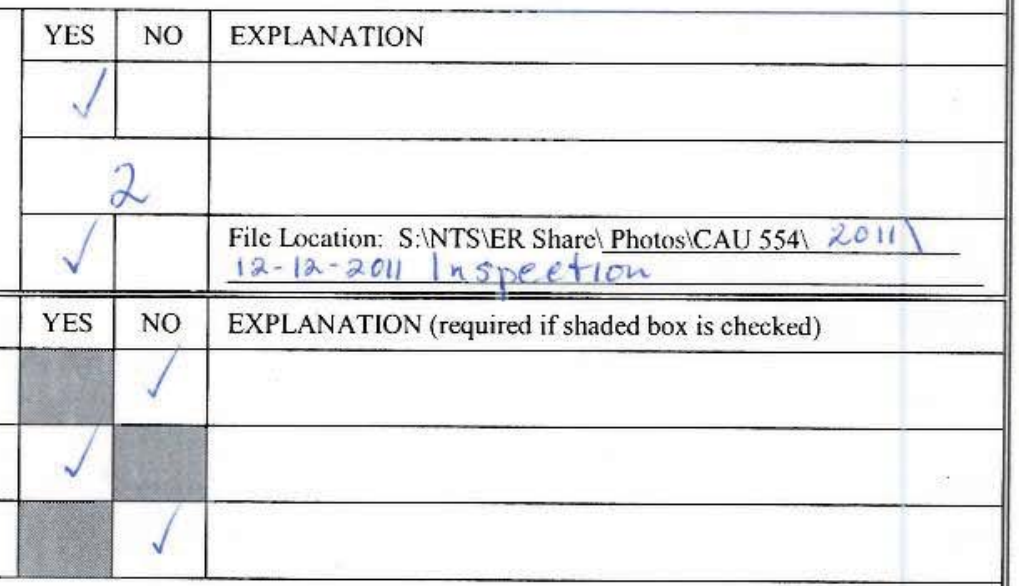

4. Field Conclusions/Recommendations: Site aud Signage in good condition. coves.

F. CERTIFICATION: I have conducted this inspection in accordance with the Post-Closure Plan as recorded on this checklist and attachments.

Chief Inspector's Signature: /s/: Rebecca King

Printed Name: Rebecea Klics

Date: $12 / 12 / 2011$
Title: 10 molect hanaser

G. VERIFICATION: I have reviewed this checklistand attachments and have verified that they are complete.

Signature: /s/: Reed J. Poderis for TAT

Date: $12 / 14 / 11$

Printed Name: Thomas A. Thiele (or designee) 
CAU 560: SEPTIC SYSTEMS 
THIS PAGE INTENTIONALLY LEFT BLANK 
POST-CLOSURE INSPECTION CHECKLIST

\section{CAU 560, SEPTIC SYSTEMS - CAS 06-05-03, LEACH PIT, AND CAS 06-05-04, LEACH BED}

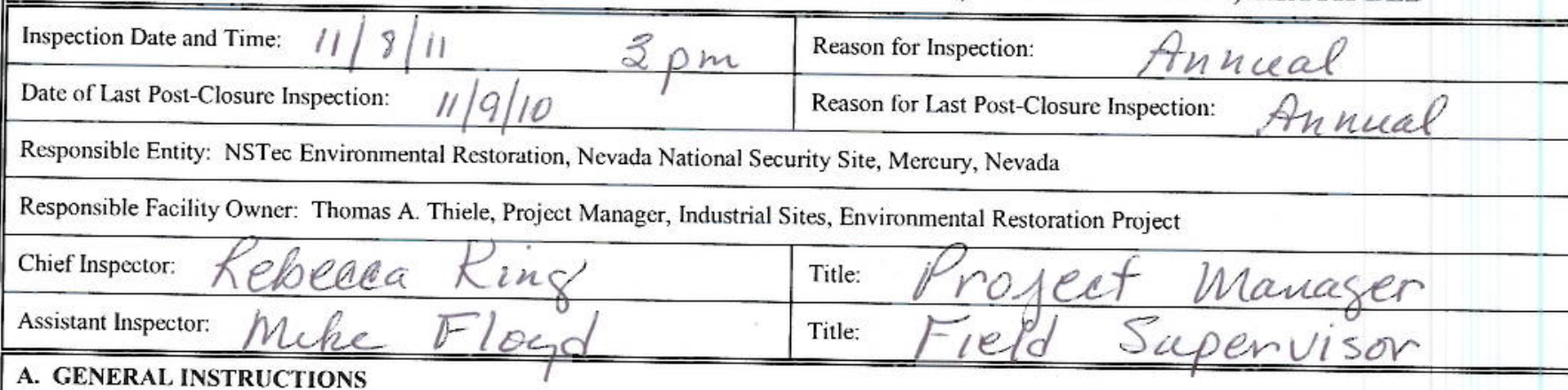

- Complete all checklist items.

- If a SHADED BOX is checked, provide detailed information and/or appropriate references to other documents that have the information.

- All documentation must be legible and clear.

\section{B. PREPARATION (To be completed prior to site visit)}

1. Has the Post-Closure Plan been reviewed?

2. Have the previous inspection reports been reviewed?

3. Were anomalies or trends detected on previous inspections?

4. Were maintenance or repair activities performed since the last inspection?

\section{SITE INSPECTION PREPARATION}

Assemble the following, as needed, to conduct inspections:

- Radio, pager, etc.

- Previous letter report, inspection checklists; repair records, and as-built plans

- Camera, digital storage drive, extra batteries, and other miscellaneous support equipment

\section{SITE INSPECTION}

- The site inspection is a walking inspection of the entire site including the perimeter and sufficient transects to be able to inspect the entire surface and all features specifically described in this checklist. The checklist should be completed during the site inspection.

- If a shaded box is checked, add detailed comments to document the results of the site inspection. Information provided should be of sufficient detail to enable reconstruction of observations regarding field conditions. The completed checklist is part of the field record of the inspection.

- Ficld notes taken to assist in completion of this checklist will become part of the inspection record. No form is specified for field notes, and additional field notes are not required if the checklist and associated attachments adequately describe site conditions.

1. Site Markers:

a. Have any posts been damaged or their anchoring weakened?

b. Are all use restriction signs legible?

c. Are any use restriction signs damaged or missing?

d. How many damaged or missing signs need to be replaced?

e. Are any use restriction signs down?

f. How many down signs need to be re-hung?

2. Use-Restricted Area

a. Is there evidence of human intrusion onto the site?

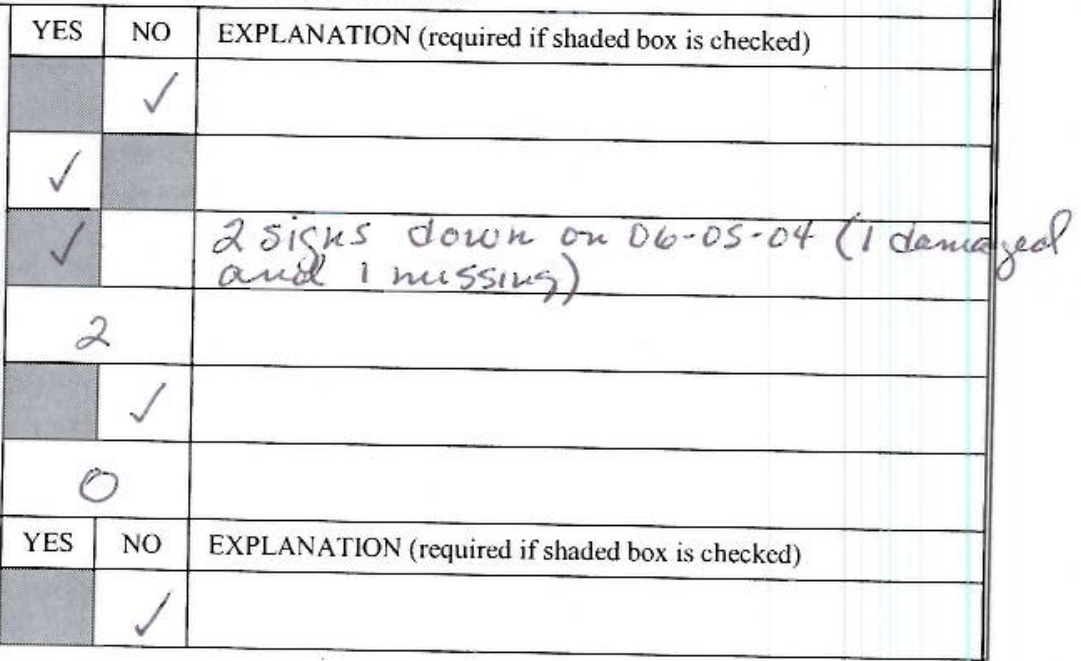


POST-CLOSURE INSPECTION CHECKLIST

\section{CAU 560, SEPTIC SYSTEMS - CAS 06-05-03, LEACH PIT, AND CAS 06-05-04, LEACH BED}

Photograph Instructions:

- Photographs should be taken to document maintenance/repair needs at the site. These will be used to plan maintenance/repair activities and are not intended for use in the annual post-closure report.

- Anomalous features or new features (such as changes in adjacent area land use) should be photographed

- Other photographs are optional.

- A photograph log entry will be made for each photograph taken.

3. Photograph Documentation:

a. Have photographs been taken of the site?

If yes, how many photos were taken?

If yes, has a photographic log been prepared?

E. FIELD CONCLUSIONS

1. Are more frequent inspections required?

2. Are existing maintenance/repair actions satisfactory?

3. Are maintenance/repair actions necessary?

\begin{tabular}{|l|l|l} 
YES & NO & EXPLANATION
\end{tabular}

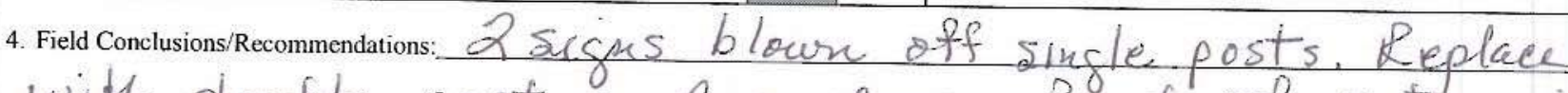
with druble post and anchors. Rest of site in good condition.

F. CERTIFICATION: I have conducted this inspection in accordance with the Post-Closure Plan as recorded on this checklist and attachments.

Chief Inspector's Signature: /s/: Rebecca King

Printed Name:

G. VERIFICATION: I have reviewed this checklist and attachments and have verified that they are complete.

Signature: /s/: Reed J. Poderis for TAT

Date: $11 / 22 / 11$

Printed Name: Thomas A. Thiele (or designee) 
CAU 561: WASTE DISPOSAL AREAS 
THIS PAGE INTENTIONALLY LEFT BLANK 


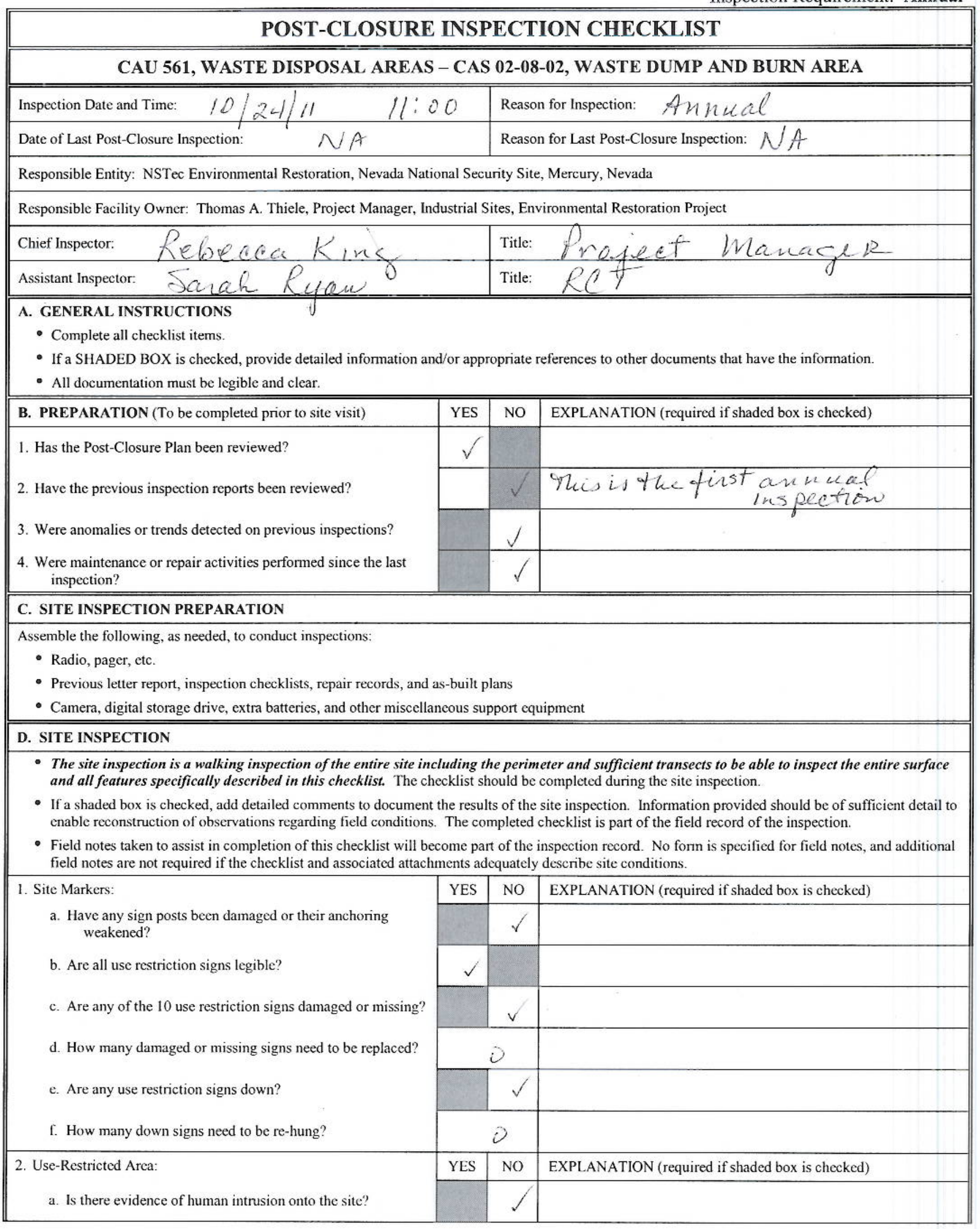




\section{POST-CLOSURE INSPECTION CHECKLIST}

\section{CAU 561, WASTE DISPOSAL AREAS - CAS 02-08-02, WASTE DUMP AND BURN AREA}

\section{Photograph Instructions:}

- Photographs should be taken to document maintenance/repair needs at the site. These will be used to plan maintenance/repair activities and are not intended for use in the annual post-closure report.

- Anomalous features or new features (such as changes in adjacent area land use) should be photographed.

- Other photographs are optional.

- A photograph log entry will be made for each photograph taken.

3. Photograph Documentation:

a. Have photographs been taken of the site?

If yes, how many photos were taken?

If yes, has a photographic log been prepared?

\begin{tabular}{||l|c|c|}
\hline \hline E. FIELD CONCLUSIONS & YES & NO \\
\hline 1. Are more frequent inspections required? & & \\
\hline 2. Are existing maintenance/repair actions satisfactory? & & \\
\hline 3. Are maintenance/repair actions necessary? & & $\sqrt{ }$ \\
\hline
\end{tabular}

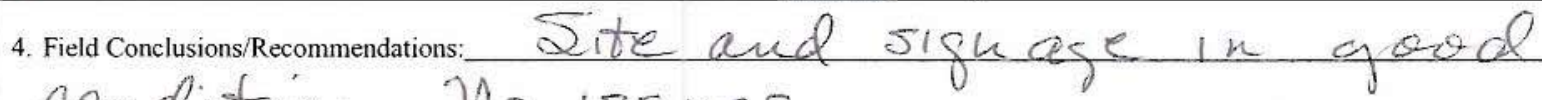

condition Mo issues.

\begin{tabular}{|c|c|c|}
\hline YES & NO & EXPLANATION \\
\hline \multicolumn{3}{|c|}{1} \\
\hline & & 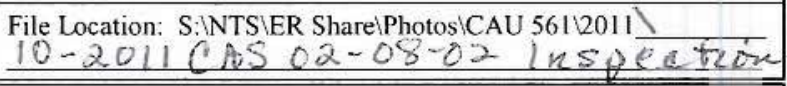 \\
\hline YES & NO & EXPLANATION (required if shaded box is checked) \\
\hline & & $=$ \\
\hline & & \\
\hline & & \\
\hline
\end{tabular}

F. CERTIFICATION: I have conducted this inspection in accordance with the Post-Closure Plan as recorded on this checklist and attachments.

Chief Inspector's Signature: /s/: Rebecca King

Printed Name: $\mathrm{Cl}$ beca

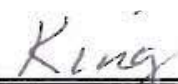

C)

\begin{tabular}{l} 
Date: $10 / 24 / 11$ \\
\hline Title: Project Manapur
\end{tabular}

G. VERIFICATION: I have reviewed this checklist and atlachments and have verilied that they are complete.

Signature: /s/: Reed J. Poderis for TAT I

Date: $11 / 4 / 1$

Printed Name: Thomas A. Thiele (or designee) 
CAU 566: EMAD COMPOUND 
THIS PAGE INTENTIONALLY LEFT BLANK 


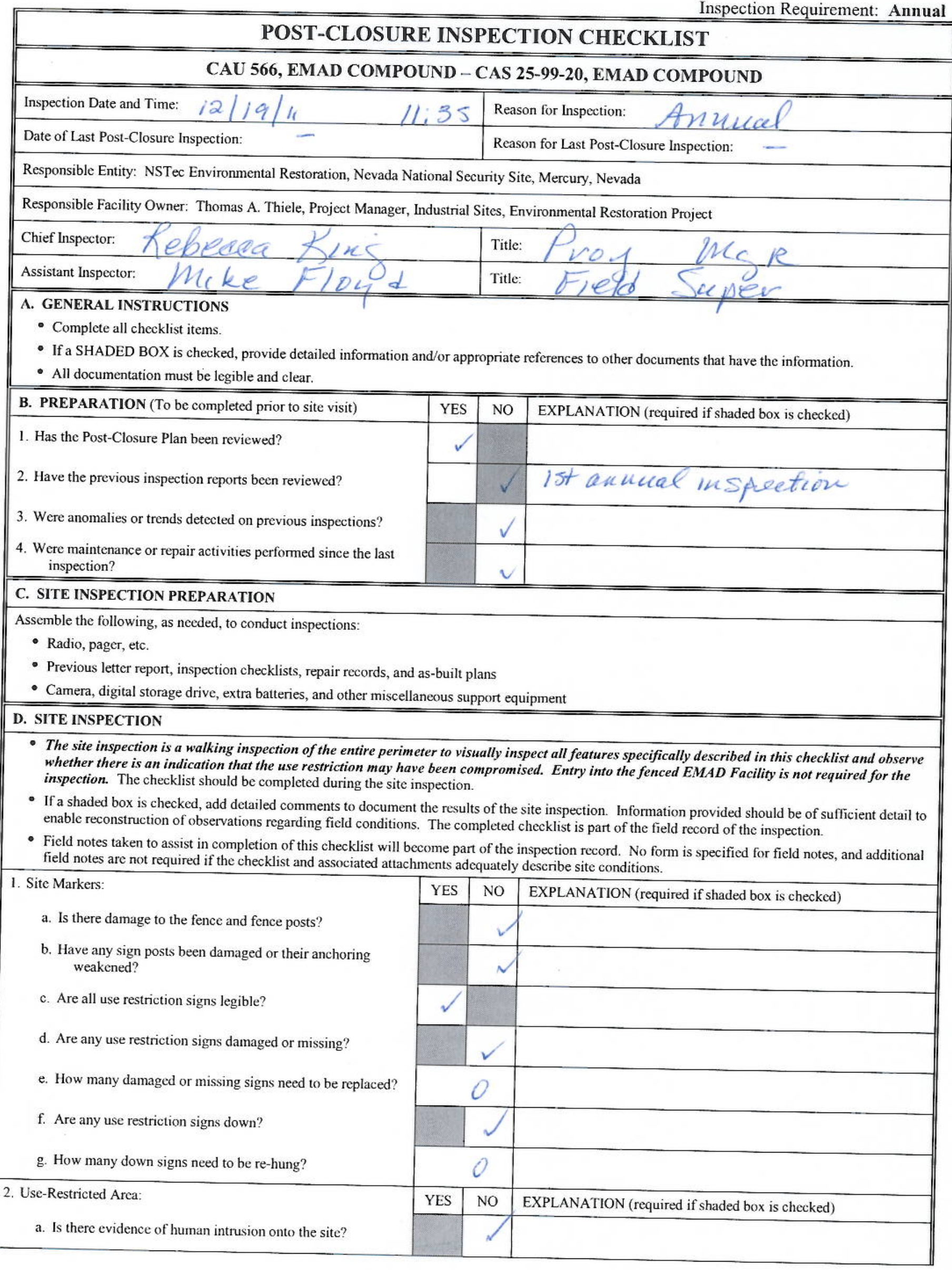


CAU 107: LOW IMPACT SOIL SITES 
THIS PAGE INTENTIONALLY LEFT BLANK 


\section{POST-CLOSURE INSPECTION CHECKLIST}

\section{CAU 107, LOW IMPACT SOIL SITES - CAS 03-23-29, TRUCHAS-CHAMISAL CONTAMINATION AREA}

\begin{tabular}{|l|l|l|l|l|}
\hline \hline Inspection Date and Time: 11 & $11: 55$ & Reason for Inspection: \\
\hline Date of Last Post-Closure Inspection: & 11111,0 & Reason for Last Post-Closure Inspection: \\
\hline
\end{tabular}

Responsible Entity: NSTec Environmental Restoration, Nevada National Security Site, Mercury, Nevada

Responsible Facility Owner: Thomas A. Thiele, Project Manager, Soils, Environmental Restoration Project

Chief Inspector:

Assistant Inspector:
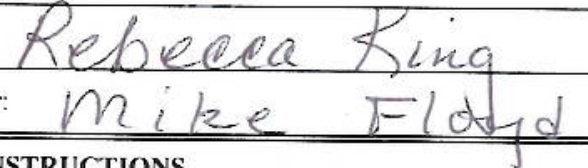

Title: Pro

\section{A. GENERAL INSTRUCTIONS}

Title: Fie ofi

- Complete all checklist items.

- If a SHADED BOX is checked, provide detailed information and/or appropriate references to other documents that have the information.

- All documentation must be legible and clear.

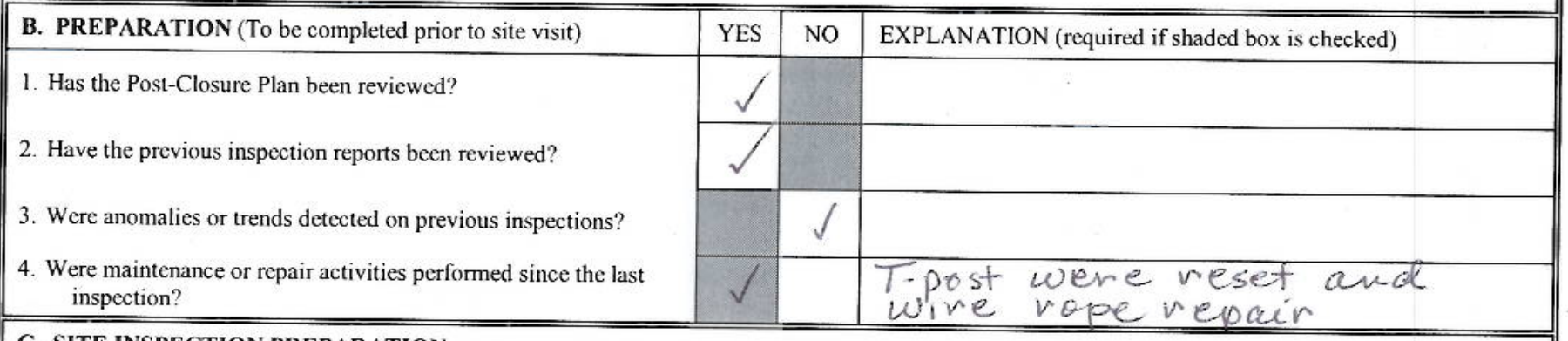

\section{SITE INSPECTION PREPARATION}

Assemble the following, as needed, to conduct inspections:

- Radio, pager, etc.

- Previous letter report, inspection checklists, repair records, and as-built plans

- Camera, digital storage drive, extra batteries, and other miscellaneous support equipment

\section{SITE INSPECTION}

- The site inspection is a walking inspection of the entire perimeter to visually inspect all features specifically described in this checklist and observe whether there is an indication that the use restriction may have been compromised. Entry into the fenced area is not required for the inspection. The checklist should be completed during the site inspection.

- If a shaded box is checked, add detailed comments to document the results of the site inspection. Information provided should be of sufficient detail to enable reconstruction of observations regarding field conditions. The completed checklist is part of the field record of the inspection.

- Field notes taken to assist in completion of this checklist will become part of the inspection record. No form is specified for field notes, and additional field notes are not required if the checklist and associated attachments adequately describe site conditions.

1. Site Markers:

a. Is there damage to the fence or fence posts?

b. Have any posts been damaged or their anchoring weakened?

c. Are all use restriction signs legible?

d. Are any of the 4 use restriction signs damaged or missing?

e. How many damaged or missing signs need to be replaced?

f. Are any use restriction signs down?

g. How many down signs need to be re-hung?

h. Do any Underground Radioactive Material Area signs need to be replaced or re-hung?

\begin{tabular}{|r|r|l||}
\hline YES & NO & EXPLANATION (required if shaded box is checked) \\
\hline & $/$ & \\
\hline & $\sqrt{ }$ & \\
\hline & & \\
\hline & $\sqrt{ }$ & \\
\hline & 0 & \\
\hline & $\sqrt{ }$ & \\
\hline & 0 & \\
\hline & $\sqrt{ }$ & \\
\hline
\end{tabular}




\section{POST-CLOSURE INSPECTION CHECKLIST}

\section{CAU 107, LOW IMPACT SOIL SITES - CAS 03-23-29, TRUCHAS-CHAMISAL CONTAMINATION AREA}

2. Use-Restricted Area:

a. Is there evidence of human intrusion onto the site?

Photograph Instructions:

- Photographs should be taken to document maintenance/repair needs at the site. These will be used to plan maintenance/repair activities and are not intended for use in the annual post-closure report.

- Anomalous features or new features (such as changes in adjacent area land use) should be photographed.

- Other photographs are optional.

- A photograph log entry will be made for each photograph taken.

3. Photograph Documentation:

a. Have photographs been taken of the site?

If yes, how many photos were taken?

If yes, has a photographic log been prepared?

\section{E. FIELD CONCLUSIONS}

1. Are more frequent inspections required?

2. Are existing maintenance/repair actions satisfactory?

3. Are maintenance/repair actions necessary?

4. Field Conclusions/Recommendations: Fencins, site in grod condition.

\begin{tabular}{|r|r|l|}
\hline YES & NO & EXPLANATION (required if shaded box is checked) \\
\hline & $\sqrt{ }$ & \\
\end{tabular}

\footnotetext{
in adjacen
} 


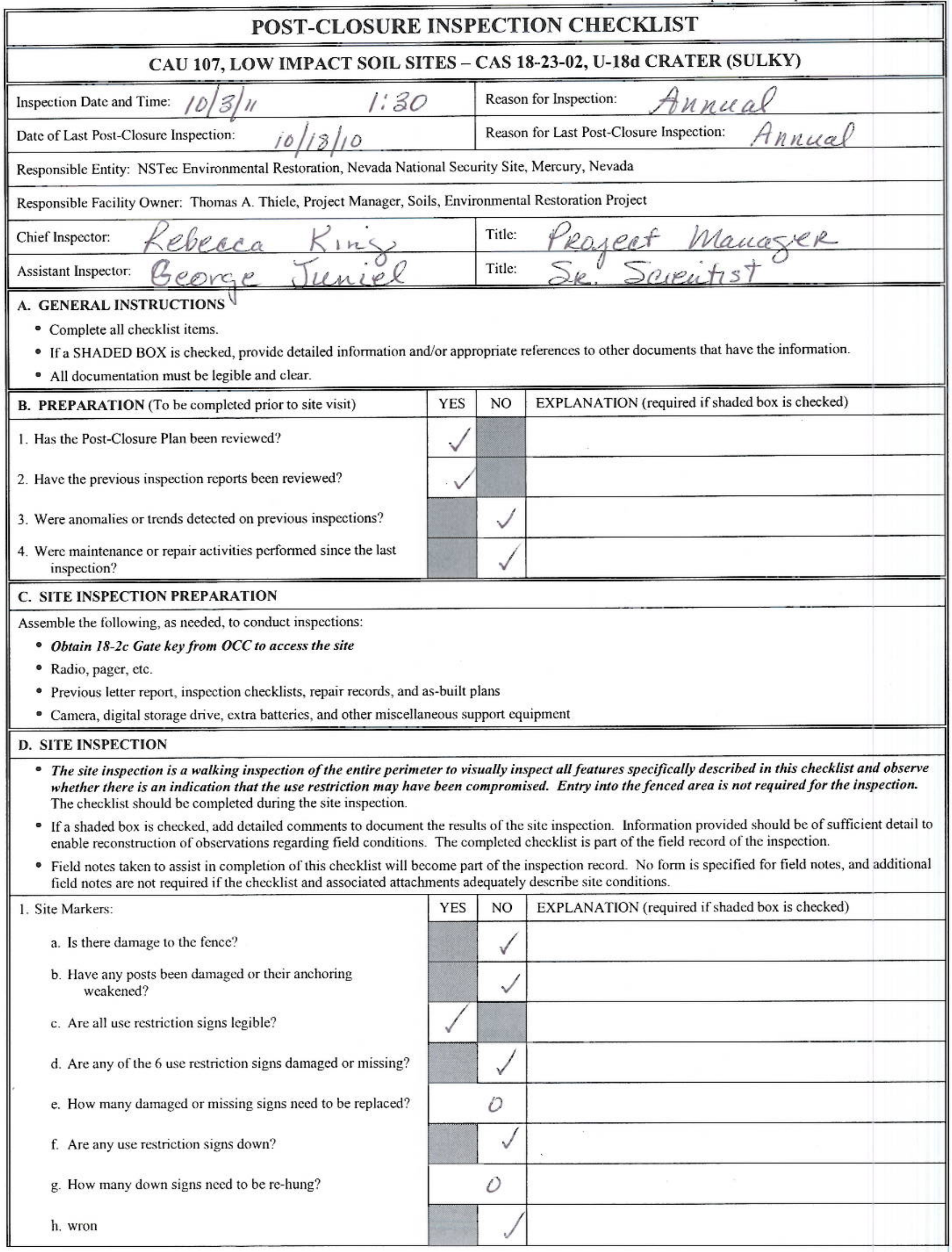




\begin{tabular}{||l|c|c|c||}
\hline \multicolumn{4}{|c||}{ POST-CLOSURE INSPECTION CHECKILIST } \\
\hline \hline \multicolumn{3}{|c||}{ CAU 107, LOW IMPACT SOIL SITES - CAS 18-23-02, U-18d CRATER (SULKY) } \\
\hline \hline 2. Use-Restricted Area: & YES & NO & EXPLANATION (required if shaded box is checked) \\
\cline { 2 - 5 } a. Is there evidence of human intrusion onto the site? & & $\sqrt{ }$ & \\
\hline
\end{tabular}

Photograph Instructions:

- Photographs should be taken to document maintenance/repair needs at the site. These will be used to plan maintenance/repair activities and are not intended for use in the annual post-closure report.

- Anomalous features or new features (such as changes in adjacent area land use) should be photographed.

- Other photographs are optional.

- A photograph log entry will be made for each photograph taken.

3. Photograph Documentation:

a. Have photographs been taken of the site?

If yes, how many photos were taken?

If yes, has a photographic log been prepared?

\begin{tabular}{||l|l|l|l||}
\hline \hline E. FIELD CONCLUSIONS & YES & NO & EXPLANATION (required if shaded box is checked) \\
\hline 1. Are more frequent inspections required? & & $\checkmark$ & \\
\hline 2. Are existing maintenance/repair actions satisfactory? & $\checkmark$ & & \\
\hline 3. Are maintenance/repair actions necessary? & & & \\
\hline
\end{tabular}

4. Field Conclusions/Recommendations: Site and fence and all postix s

in good condition.

F. CERTIFICATION: I have conducted this inspection in accordance with the Post-Closure Plan as recorded on this checklist and attachments.

Chief Inspector's Signature: /s/: Rebecca King

Printed Name:
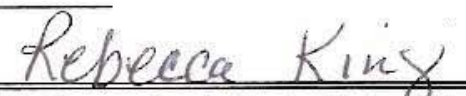

$\circlearrowleft$

G. VERIFICATION: I have reviewed this checklist and attachments and have verified that they are complete.

Signature: /s/: Reed J. Poderis for TAT (I

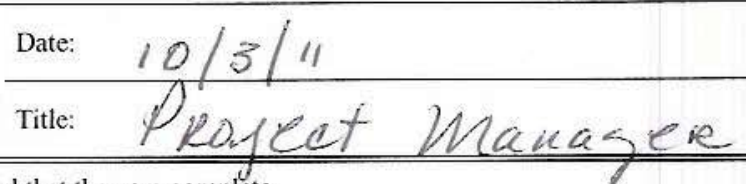

Date: $10 / 18 / 2011$

Printed Name: Thomas A. Thiele (or designee) 
CAU 365: BANEBERRY CONTAMINATION AREA 
THIS PAGE INTENTIONALLY LEFT BLANK 


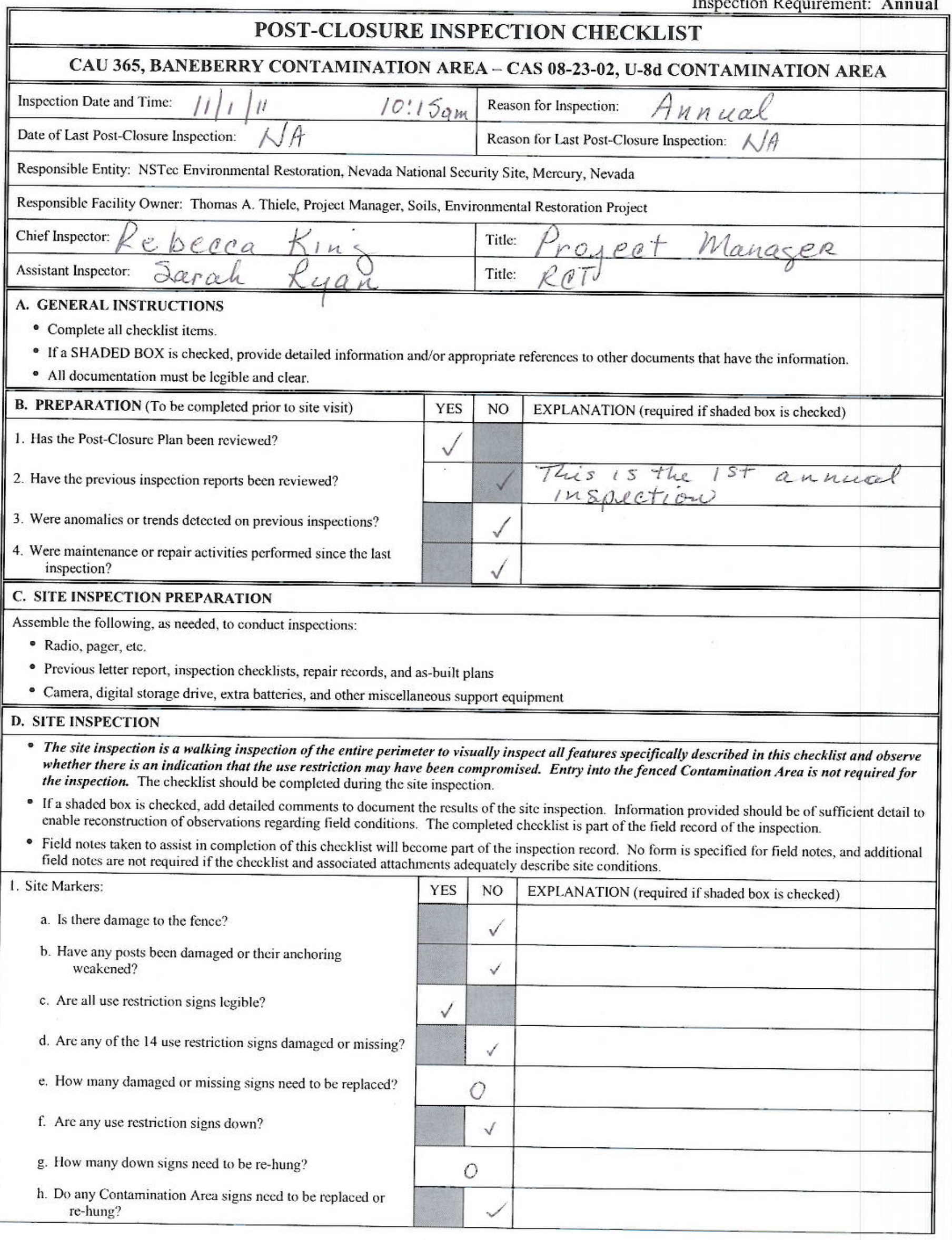


POST-CLOSURE INSPECTION CHECKLIST

\section{CAU 365, BANEBERRY CONTAMINATION AREA - CAS 08-23-02, U-8d CONTAMINATION AREA}

2. Use-Restricted Area:

a. Is there evidence of human intrusion onto the site?

\section{Photograph Instructions:}

- Photographs should be taken to document maintenance/repair needs at the site. These will be used to plan maintenance/repair activities and are not intended for use in the annual post-closure report.

- Anomalous features or new features (such as changes in adjacent area land use) should be photographed.

- Other photographs are optional.

- A photograph log entry will be made for each photograph taken.

3. Photograph Documentation:

a. Have photographs been taken of the site?

If yes, how many photos were taken?

If yes, has a photographic log been prepared?

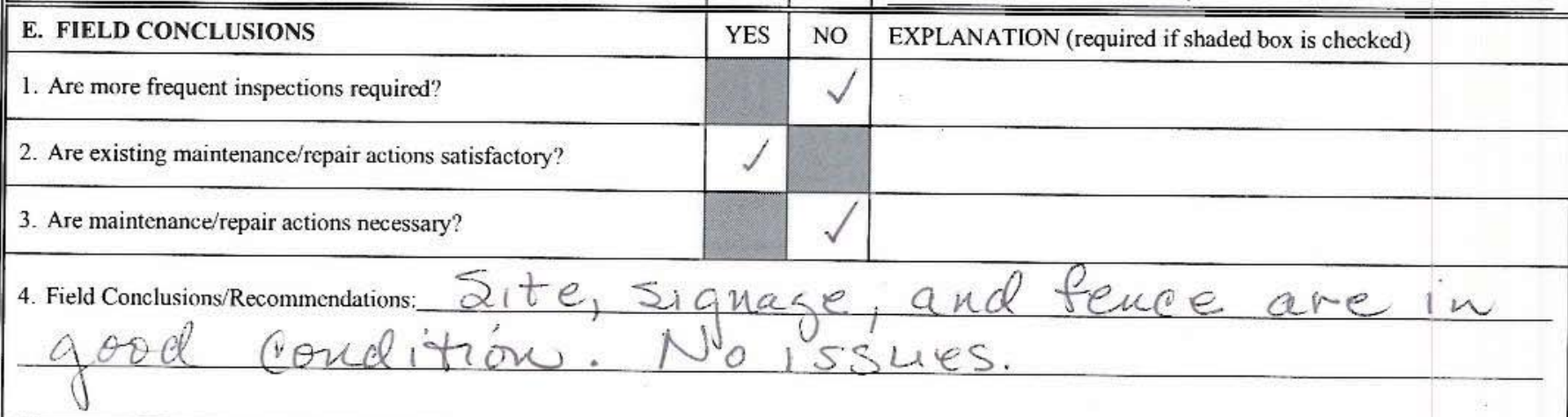

F. CERTIFICATION: I have conducted this inspection in accordance with the Post-Closure Plan as recorded on this checklist and attachments. Chief Inspector's Signature: /s/: Rebecca King Printed Name: Reboleca

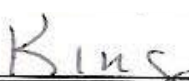

U

\begin{tabular}{l} 
Date: $\|/ 1 /\|$ \\
\hline Title: \\
ied that they are complete \\
Date: $11 / \mathrm{H} / \|$
\end{tabular}

G. VERIFICATION: I have reviewed this checklist and attachments and have verified that they are completed

Signature: /s/: Reed J. Poderis for TAT

Printed Name: Thomas A. Thiele (or designee) 
CAU 367: AREA 10 SEDAN, ESS AND UNCLE UNIT CRATERS 
THIS PAGE INTENTIONALLY LEFT BLANK 


\begin{tabular}{|c|c|c|c|}
\hline \multicolumn{4}{|c|}{ POST-CLOSURE INSPECTION CHECKLIST } \\
\hline \multicolumn{4}{|c|}{$\begin{array}{l}\text { CAU 367, AREA } 10 \text { SEDAN, ESS AND UNCLE UNIT CRATERS - CAS 10-45-01, U-10h CRATER (SEDAN), } \\
\text { CAS 10-45-02, ESS CRATER SITE, AND CAS 10-45-03, UNCLE CRATER SITE }\end{array}$} \\
\hline \multicolumn{2}{|l|}{ Inspection Date and Time: $\quad 10 / 27 / 11 \quad 10 ; 50 \mathrm{am}$} & \multicolumn{2}{|c|}{ Reason for Inspection: Annucel } \\
\hline \multicolumn{2}{|l|}{ Date of Last Post-Closure Inspection: $\quad N A$} & \multicolumn{2}{|c|}{ Reason for Last Post-Closure Inspection: $N A$} \\
\hline \multicolumn{4}{|c|}{ Responsible Entity: NSTec Environmental Restoration, Nevada National Security Site, Mercury, Nevada } \\
\hline \multicolumn{4}{|c|}{ Responsible Facility Owner: Thomas A. Thicle, Project Manager, Soils, Environmental Restoration Project } \\
\hline \multicolumn{2}{|l|}{ Chief Inspector: Rebeeca } & \multicolumn{2}{|c|}{ Title: Propeef Manacer } \\
\hline \multicolumn{2}{|l|}{ Assistant Inspector: Seott Robents } & \multicolumn{2}{|c|}{ Title: $\quad R C T$} \\
\hline \multicolumn{4}{|c|}{$\begin{array}{l}\text { A. GENERAL INSTRUCTIONS } \\
\text { - Complete all checklist items. } \\
\text { - If a SHADED BOX is checked, provide detailed information and/or appropriate references to other documents that have the information. } \\
\text { - All documentation must be legible and clear. }\end{array}$} \\
\hline B. PREPARATION (To be completed prior to site visit) & YES & NO & EXPLANATION (required if shaded box is checked) \\
\hline \multicolumn{4}{|l|}{ 1. Has the Post-Closure Plan been reviewed? } \\
\hline \multicolumn{4}{|c|}{ 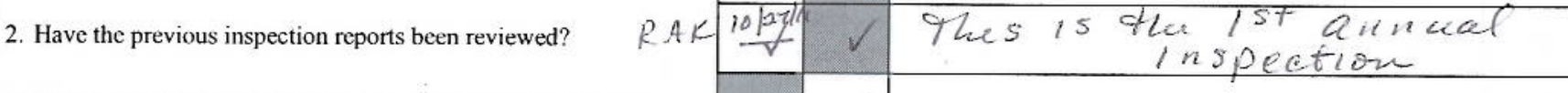 } \\
\hline \multirow{2}{*}{$\begin{array}{l}\text { 3. Were anomalies or trends detected on previous inspections? } \\
\text { 4. Were maintenance or repair activities performed since the last } \\
\text { inspection? }\end{array}$} & & $\gamma$ & \\
\hline & & & \\
\hline
\end{tabular}

\section{SITE INSPECTION PREPARATION}

Assemble the following, as needed, to conduct inspections:

- Radio, pager, etc.

- Previous letter report, inspection checklists, repair records, and as-built plans

- Camera, digital storage drive, extra batteries, and other miscellaneous support equipment

\section{SITE INSPECTION}

- The site inspection is a walking inspection of the entire perimeter to visually inspect all features specifically described in this checklist and observe whether there is an indication that the use restriction may have been compromised. Entry into the use-restricted area is not required for the inspection. The checklist should be completed during the site inspection.

- If a shaded box is checked, add detailed comments to document the results of the site inspection. Information provided should be of sufficient detail to enable reconstruction of observations regarding field conditions. The completed checklist is part of the field record of the inspection.

- Field notes taken to assist in completion of this checklist will become part of the inspection record. No form is specified for field notes, and additional field notes are not required if the checklist and associated attachments adequately describe site conditions.

1. Site Markers (CAS 10-45-01):

a. Have any posts been damaged or their anchoring weakened?

b. Are all use restriction signs legible?

c. Are any of the 21 use restriction signs damaged or missing?

d. How many damaged or missing signs need to be replaced?

e. Are any use restriction signs down?

f. How many down signs need to be re-hung?

g. Does the historical sign need to be replaced or re-hung?

2. Use-Restricted Area (CAS 10-45-01):

a. Is there evidence of human intrusion onto the site?

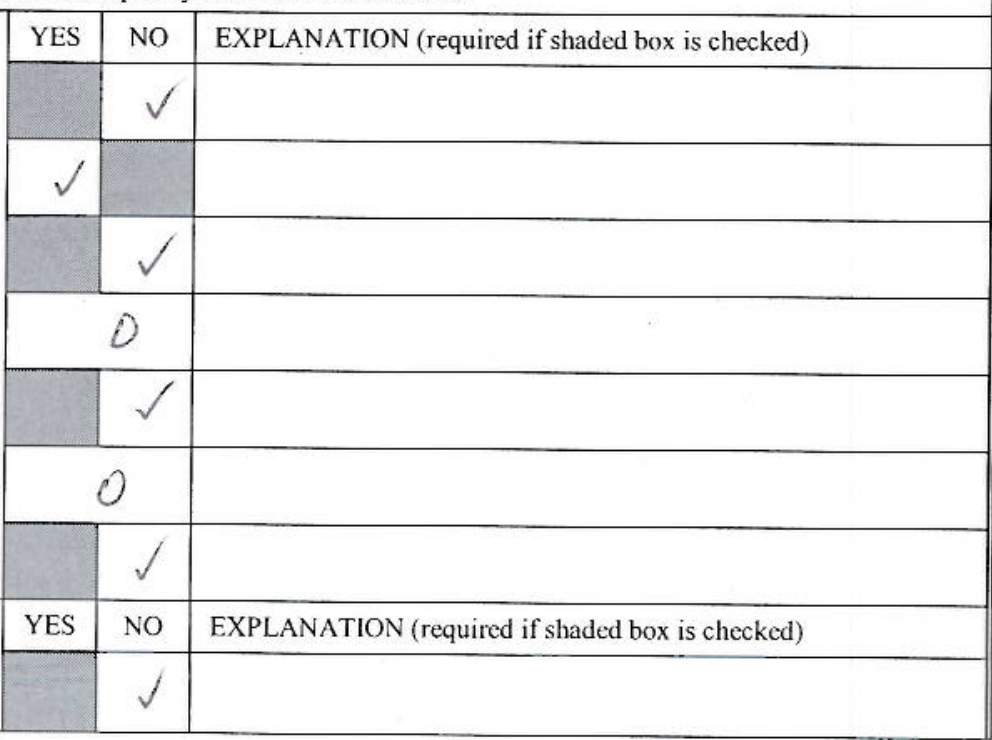




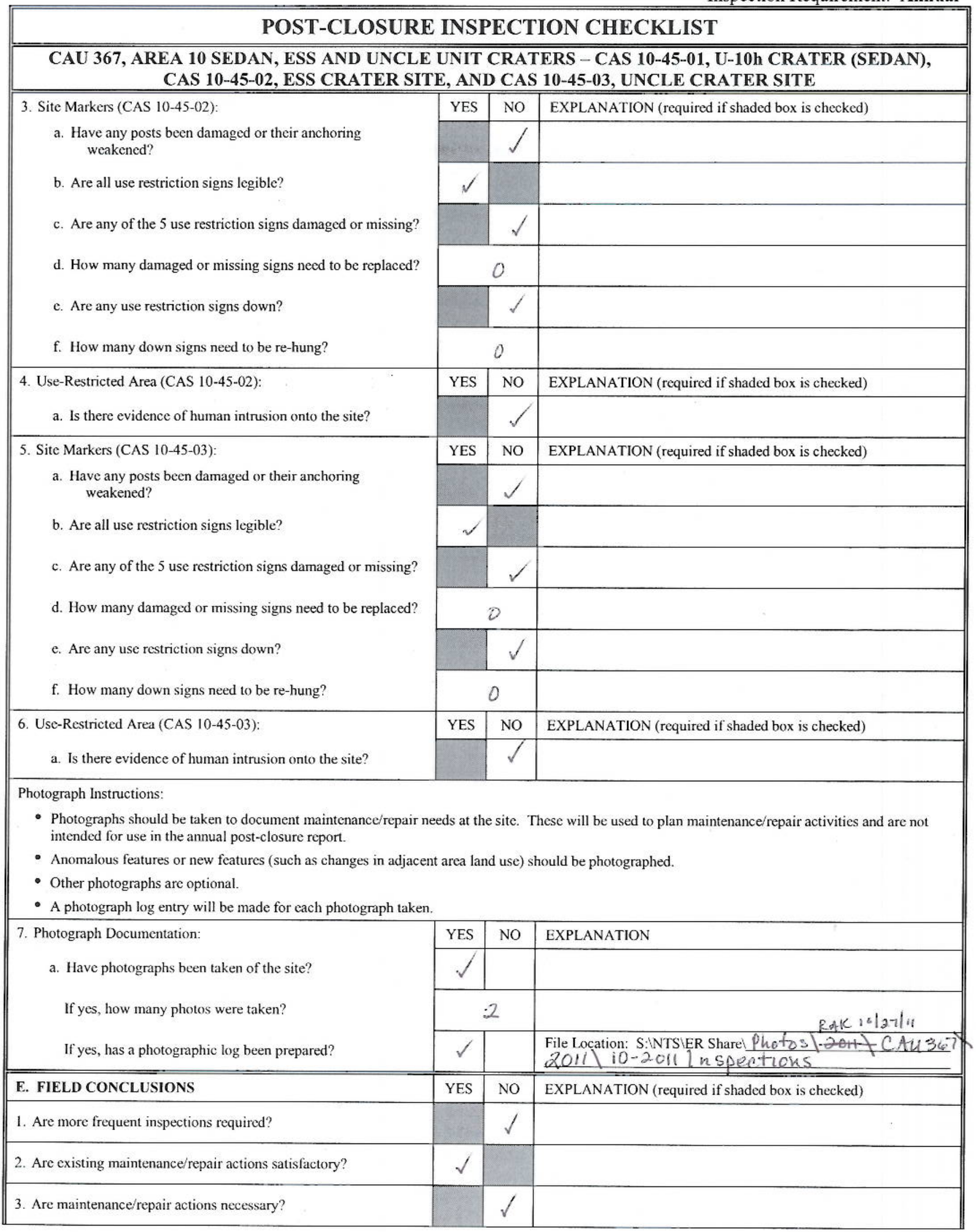


POST-CLOSURE INSPECTION CHECKLIST

CAU 367, AREA 10 SEDAN, ESS AND UNCLE UNIT CRATERS - CAS 10-45-01, U-10h CRATER (SEDAN), CAS 10-45-02, ESS CRATER SITE, AND CAS 10-45-03, UNCLE CRATER SITE

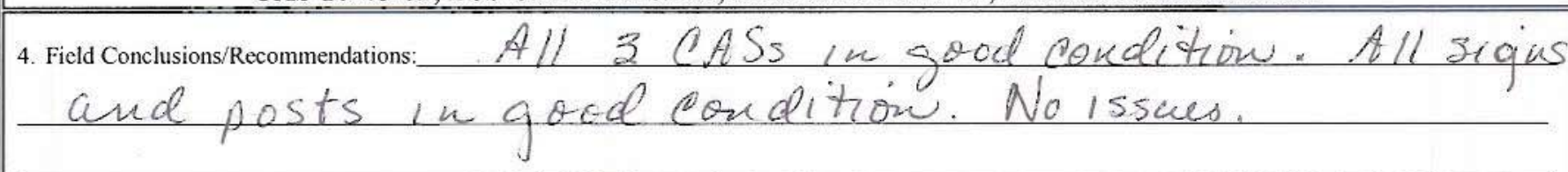

F. CERTIFICATION: I have conducted this inspection in accordance with the Post-Closure Plan as recorded on this checklist and attachments.

Chief Inspector's Signature:/s/: Rebecca King

Printed Name:

Reloecea

Kir

G. VERIFICATION: I have reviewed this checklist and attachments and have verified that they are complete

Signature: /s/: Reed J. Poderis for TAT

Date: $11 / 7 / 11$

Printed Name: Thomas A. Thiele (or designec) 
THIS PAGE INTENTIONALLY LEFT BLANK 
CAU 370: T-4 ATMOSPHERIC TEST SITE 
THIS PAGE INTENTIONALLY LEFT BLANK 


\begin{tabular}{|c|c|c|c|}
\hline \multicolumn{4}{|c|}{ POST-CLOSURE INSPECTION CHECKLIST } \\
\hline \multicolumn{4}{|c|}{ CAU 370, T-4 ATMOSPHERIC TEST SITE - CAS 04-23-01, ATMOSPHERIC TEST SITE T-4 } \\
\hline \multicolumn{2}{|l|}{ Date of Last Post-Closure Inspection: $\quad 11 / 29 / 10$} & \multicolumn{2}{|c|}{ Reason for Last Post-Closure Inspection: An in ccal } \\
\hline \multicolumn{2}{|l|}{ Chief Inspector: Pebeqa Kisy } & \multicolumn{2}{|c|}{ Title: Prosogf WhanasRR } \\
\hline \multicolumn{2}{|l|}{ Assistant Inspector: Mclee Flor of } & \multicolumn{2}{|c|}{ Title: Fleld Superilisol } \\
\hline \multicolumn{4}{|c|}{$\begin{array}{l}\text { A. GENERAL INSTRUCTIONS } \\
\text { - Complete all checklist items. } \\
\text { - If a SHADED BOX is checked, provide detailed information and/or appropriate references to other documents that have the information. } \\
\text { - All documentation must be legible and clear. }\end{array}$} \\
\hline B. PREPARATION (To be completed prior to site visit) & YES & NO & EXPLANATION (required if shaded box is checked) \\
\hline \multicolumn{4}{|l|}{ 1. Has the Post-Closure Plan been reviewed? } \\
\hline \multicolumn{4}{|l|}{ 2. Have the previous inspection reports been reviewed? } \\
\hline \multirow{2}{*}{$\begin{array}{l}\text { 3. Were anomalies or trends detected on previous inspections? } \\
\text { 4. Were maintenance or repair activities performed since the last } \\
\text { inspection? }\end{array}$} & & & \\
\hline & & & sigin and guence kepaik \\
\hline \multicolumn{4}{|l|}{ C. SITE INSPECTION PREPARATION } \\
\hline \multicolumn{4}{|l|}{ D. SITE INSPECTION } \\
\hline \multirow{2}{*}{$\begin{array}{l}\text { 1. Site Markers: } \\
\text { a. Is there damage to the fence or fence posts? }\end{array}$} & YES & NO & EXPLANATION (required if shaded box is checked) \\
\hline & & & Fence wive diren lu 3 areas \\
\hline $\begin{array}{l}\text { b. Have any sign posts been damaged or their anchoring } \\
\text { weakened? }\end{array}$ & & & \\
\hline c. Are all use restriction signs legible? & & & 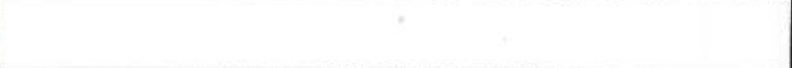 \\
\hline d. Are any use restriction signs damaged or missing? & & & \\
\hline e. How many damaged or missing signs need to be replaced? & & & \\
\hline f. Are any use restriction signs down? & & & $\begin{array}{l}7 \text { sigks are down aud } 1 \text { is } \\
\text { lopee at a connek }\end{array}$ \\
\hline g. How many down signs need to be re-hung? & & & \\
\hline $\begin{array}{l}\text { h. Do any Radioactive Material Area signs need to be replaced } \\
\text { or re-hung? }\end{array}$ & & & \\
\hline
\end{tabular}

Page 1 of 2 


\section{POST-CLOSURE INSPECTION CHECKLIST}

\section{CAU 370, T-4 ATMOSPHERIC TEST SITE - CAS 04-23-01, ATMOSPHERIC TEST SITE T-4}

2. Use-Restricted Area:

a. Is there evidence of human intrusion onto the site?

\begin{tabular}{|l|l|l|l} 
YES & NO & EXPLANATION (required if shaded box is checked) \\
\hline
\end{tabular}

Photograph Instructions:

- Photographs should be taken to document maintenance/repair needs at the site. These will be used to plan maintenance/repair activities and are not intended for use in the annual post-closure report.

- Anomalous features or new features (such as changes in adjacent area land use) should be photographed.

- Other photographs are optional.

- A photograph log entry will be made for each photograph taken.

3. Photograph Documentation:

a. Have photographs been taken of the site?

If yes, how many photos were taken?

If yes, has a photographic log been prepared?

\section{E. FIELD CONCLUSIONS}

1. Are more frequent inspections required?

2. Are existing maintenance/repair actions satisfactory?

3. Are maintenance/repair actions necessary?

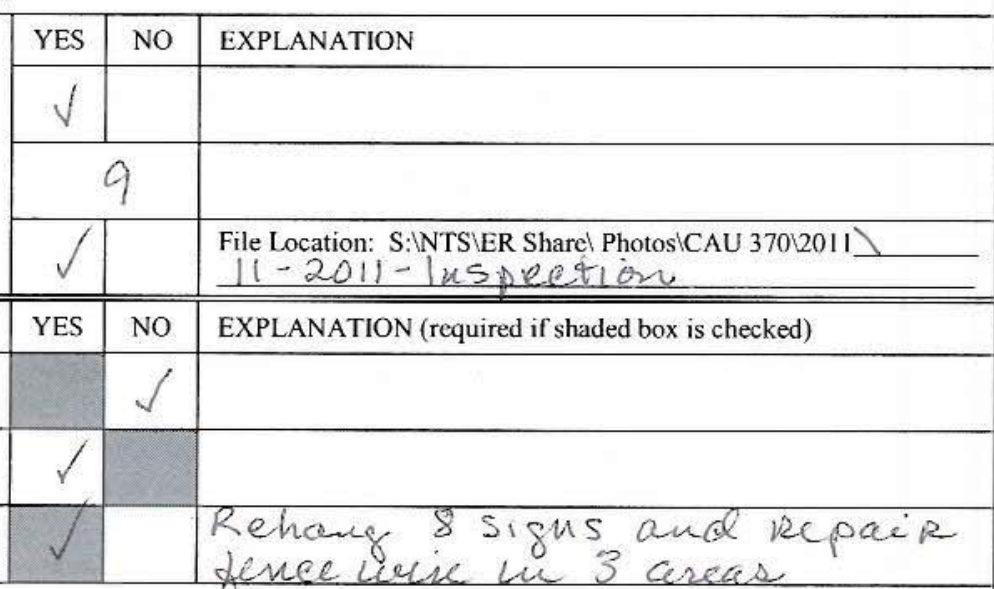

4. Field Conclusions/Recommendations: Weecen (7) 4 R siguc are doury and one 1 ) is

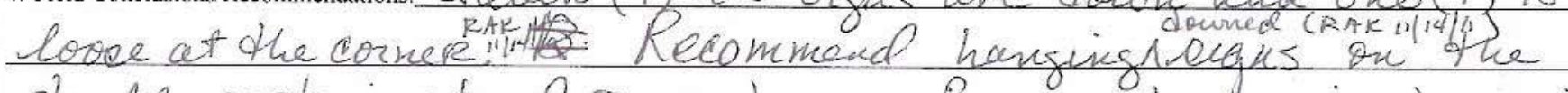

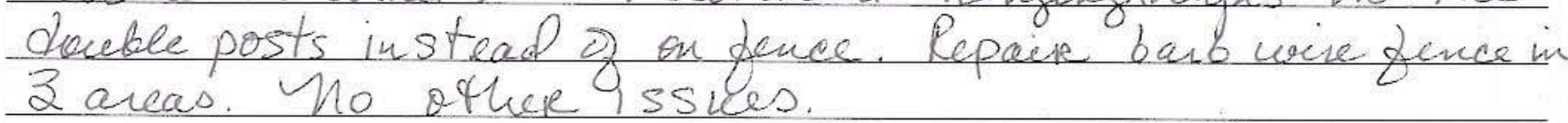

F. CERTIFICATION: I have conducted this inspection in accordance with the Post-Closure Plan as recorded on this checklist and attachments.

Chief Inspector's Signature: /s/: Rebecca King

Printed Name: Refoequa Kins

G. VERIFICATION: I have reviewed this checklist and attachments and have verified that they are complete.

Signature: /s/: Reed J. Poderis for TAT $\quad$ Date: $11 / 28 / 1 /$

Printed Name: Thomas A. Thicle (or designee) 
CAU 371: JOHNNIE BOY CRATER AND PIN STRIPE 
THIS PAGE INTENTIONALLY LEFT BLANK 
POST-CLOSURE INSPECTION CHECKLIST

\section{CAU 371, JOHNNIE BOY CRATER AND PIN STRIPE - CAS 11-23-05, PIN STRIPE CONTAMINATION AREA}

\begin{tabular}{|c|c|c|}
\hline Inspection Date and Time: $\quad 1 / 1 / 411$ & $11 ; 450 m$ & 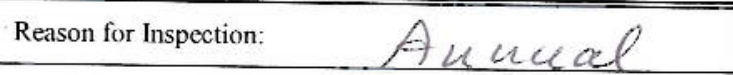 \\
\hline Date of Last Post-Closure Inspection: $/ / /$ & 10 & Reason for Last Post-Closure Inspection: $4 \mathrm{n} 21 \mathrm{Lal}$ \\
\hline
\end{tabular}

Responsible Entity: NSTec Environmental Restoration, Nevada National Security Site, Mercury, Nevada

Responsible Facility Owner: Thomas A. Thiele, Project Manager, Soils, Environmental Restoration Project

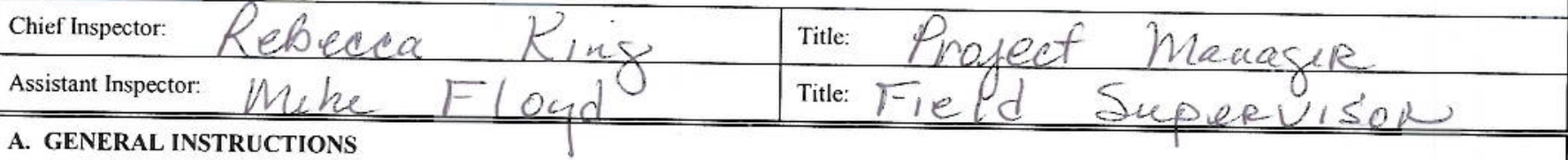

\section{A. GENERAL INSTRUCTIONS}

- Complete all checklist items.

- If a SHADED BOX is checked, provide detailed information and/or appropriate references to other documents that have the information

- All documentation must be legible and clear.

\section{B. PREPARATION (To be completed prior to site visit)}

1. Has the Post-Closure Plan been reviewed?

2. Have the previous inspection reports been reviewed?

3. Were anomalies or trends detected on previous inspections?

4. Were maintenance or repair activities performed since the last inspection?

\section{SITE INSPECTION PREPARATION}

Assemble the following, as needed, to conduct inspections:

- Radio, pager, etc.

- Previous letter report, inspection checklists, repair records, and as-built plans

- Camera, digital storage drive, extra batteries, and other miscellaneous support equipment

\section{SITE INSPECTION}

- The site inspection is a walking inspection of the entire perimeter to visually inspect all features specifically described in this checklist and observe whether there is an indication that the use restriction may have been compromised. Entry into the use-restricted area is not required for the inspection. The checklist should be completed during the site inspection.

- If a shaded box is checked, add detailed comments to document the results of the site inspection. Information provided should be of sufficient detail to enable reconstruction of observations regarding field conditions. The completed checklist is part of the field record of the inspection.

- Field notes taken to assist in completion of this checklist will become part of the inspection record. No form is specified for field notes, and additional field notes are not required if the checklist and associated attachments adequately describe site conditions.

1. Site Markers:

a. Have any posts been damaged or their anchoring weakened?

b. Are all use restriction signs legible?

c. Are any of the 11 use restriction signs damaged or missing?

d. How many damaged or missing signs need to be replaced?

e. Are any use restriction signs down?

f. How many down signs need to be re-hung?

2. Use-Restricted Area:

a. Is there evidence of human intrusion onto the site?

\begin{tabular}{|c|c|l||}
\hline YES & NO & EXPLANATION (required if shaded box is checked) \\
\hline & $\checkmark$ & \\
\hline$\checkmark$ & & \\
\hline$\checkmark$ & & Onl4 75 -igh 10 ce ted \\
\hline & 4 & \\
\hline & $\checkmark$ & \\
\hline & 0 & \\
\hline YES & NO & EXPLANATION (required if shaded box is checked) \\
\hline & $\checkmark$ & \\
\hline
\end{tabular}


POST-CLOSURE INSPECTION CHECKLIST

\section{CAU 371, JOHNNIE BOY CRATER AND PIN STRIPE - CAS 11-23-05, PIN STRIPE CONTAMINATION AREA}

Photograph Instructions:

- Photographs should be taken to document maintenance/repair needs at the site. These will be used to plan maintenance/repair activities and are not intended for use in the annual post-closure report.

- Anomalous features or new features (such as changes in adjacent area land use) should be photographed.

- Other photographs are optional.

- A photograph log entry will be made for each photograph taken.

3. Photograph Documentation:

a. Have photographs been taken of the site?

If yes, how many photos were taken?

If yes, has a photographic $\log$ been prepared?

\section{E. FIELD CONCLUSIONS \\ 1. Are more frequent inspections required?}

2. Are existing maintenance/repair actions satisfactory?

3. Are maintenance/repair actions necessary?

4. Field Conclusions/Recommendations:

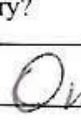

\section{inly 7}

\begin{tabular}{|r|l|l|l|}
\hline YES & NO & EXP \\
\hline$\checkmark$ & & \\
\hline \multicolumn{2}{|c|}{3} & \\
\hline$\checkmark$ & & F \\
\hline YES & NO & EXP \\
\hline
\end{tabular}

EXPLANATION

2 sigas on west and 2 on north as a Bmp to define uR boundary. 710 other issues

F. CERTIFICATION: I have conducted this inspection in accordance with the Post-Closure Plan as recorded on this checklist and attachments.

Chief Inspector's Signature:/s/: Rebecca King

Printed Name: Kebeqea Kius

Date: $11 / 14 / 11$

G. VERIFICATION: I have reviewed this checklist and attachments and have verified that they are complete.

Signature: /s/: Reed J. Poderis for TAT

Date: $11 / 21 / 11$

Printed Name: Thomas A. Thicle (or designee) 


\begin{tabular}{|c|c|c|c|}
\hline \multicolumn{4}{|c|}{ POST-CLOSURE INSPECTION CHECKLIST } \\
\hline \multicolumn{4}{|c|}{ CAU 371, JOHNNIE BOY CRATER AND PIN STRIPE - CAS 18-45-01, U-18j-2 CRATER (JOHNNIE BOY) } \\
\hline \multicolumn{2}{|l|}{ Inspection Date and Time: $10 / 3 / 11 \quad 12: 00$} & \multicolumn{2}{|c|}{ Reason for Inspection: } \\
\hline \multicolumn{2}{|l|}{ Date of Last Post-Closure Inspection: $\quad 10 / 18 / i i$} & \multicolumn{2}{|c|}{ Reason for Last Post-Closure Inspection: Af $n$ n $u$ all } \\
\hline \multicolumn{4}{|c|}{ Responsible Entity: NSTec Environmental Restoration, Nevada National Security Site, Mercury, Nevada } \\
\hline \multicolumn{4}{|c|}{ Responsible Facility Owner: Thomas A. Thiele, Project Manager, Soils, Environmental Restoration Project } \\
\hline \multicolumn{2}{|l|}{ Chief Inspector: } & Title: & Yeoyes \\
\hline \multicolumn{2}{|l|}{ Assistant Inspector: George. Jun ref } & Title: & Sie. $\quad$ Socenfist \\
\hline \multicolumn{4}{|c|}{$\begin{array}{l}\text { A. GENERAL INSTRUCTIONS } \\
\text { - Complete all checklist items. } \\
\text { - If a SHADED BOX is checked, provide detailed information and/or appropriate references to other documents that have the information. } \\
\text { - All documentation must be legible and clear. }\end{array}$} \\
\hline B. PREPARATION (To be completed prior to site visit) & YES & NO & EXPLANATION (required if shaded box is checked) \\
\hline \\
\hline \multicolumn{4}{|l|}{ 2. 2. Have the previous inspection reports been reviewed? } \\
\hline \\
\hline & & & \\
\hline \multicolumn{4}{|l|}{ C. SITE INSPECTION PREPARATION } \\
\hline \multicolumn{4}{|c|}{$\begin{array}{l}\text { Assemble the following, as needed, to conduct inspections: } \\
\text { - Radio, pager, etc. } \\
\text { - Previous letter report, inspection checklists, repair records, and as-built plans } \\
\text { - Camera, digital storage drive, extra batteries, and other miscellaneous support equipment }\end{array}$} \\
\hline \multicolumn{4}{|l|}{ D. SITE INSPECTION } \\
\hline \multicolumn{4}{|c|}{$\begin{array}{l}\text { - The site inspection is a walking inspection of the entire perimeter to visually inspect all features specifically described in this checklist and observe } \\
\text { whether there is an indication that the use restriction may have been compromised. Entry into the use-restricted area is not required for the } \\
\text { inspection. The checklist should be completed during the site inspection. } \\
\text { - If a shaded box is checked, add detailed comments to document the results of the site inspection. Information provided should be of sufficient detail to } \\
\text { enable reconstruction of observations regarding field conditions. The completed checklist is part of the field record of the inspection. } \\
\text { - Field notes taken to assist in completion of this checklist will become part of the inspection record. No form is specified for field notes, and additional } \\
\text { field notes are not required if the checklist and associated attachments adequately describe site conditions. }\end{array}$} \\
\hline \multirow{3}{*}{$\begin{array}{l}\text { 1. Site Markers: } \\
\text { a. Have any posts been damaged or their anchoring } \\
\text { weakened? } \\
\text { b. Are all use restriction signs legible? }\end{array}$} & YES & NO & EXPLANATION (required if shaded box is checked) \\
\hline & & & . \\
\hline & & & \\
\hline \multicolumn{4}{|l|}{ c. Are any of the 9 use restriction signs damaged or missing? } \\
\hline d. How many damaged or missing signs need to be replaced? & \multicolumn{2}{|c|}{0} & \\
\hline \multicolumn{4}{|l|}{ e. Are any use restriction signs down? } \\
\hline f. How many down signs need to be re-hung? & & & \\
\hline 2. Use-Restricted Area: & YES & NO & EXPLANATION (required if shaded box is checked) \\
\hline a. Is there evidence of human intrusion onto the site? & & $\checkmark$ & \\
\hline
\end{tabular}


POST-CLOSURE INSPECTION CHECKLIST

CAU 371, JOHNNIE BOY CRATER AND PIN STRIPE - CAS 18-45-01, U-18j-2 CRATER (JOHNNIE BOY)

Photograph Instructions:

- Photographs should be taken to document maintenance/repair needs at the site. These will be used to plan maintenance/repair activities and are not intended for use in the annual post-closure report.

- Anomalous features or new features (such as changes in adjacent area land use) should be photographed.

- Other photographs are optional.

- A photograph log entry will be made for each photograph taken.

3. Photograph Documentation:

a. Have photographs been taken of the site?

If yes, how many photos were taken?

If yes, has a photographic log been prepared?

\section{E. FIELD CONCLUSIONS}

1. Are more frequent inspections required?

2. Are existing maintenance/repair actions satisfactory?

3. Are maintenance/repair actions necessary?

4. Field Conclusions/Recommendations: All sisms and posts are la.govel condition. Mo issues.

F. CERTIFICATION: I have conducted this inspection in accordance with the Post-Closure Plan as recorded on this checklist and attachments.

Chief Inspector's Signature:/s/: Rebecca King

Printed Name: Kebecea King

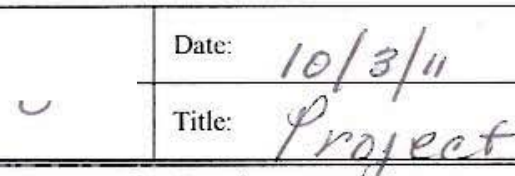

G. VERIFICATION: I have reviewed this checklist and attachments and have verified that they are contiplete.

Signature: $/ \mathrm{s} / \mathrm{:}$ Reed J. Poderis for TAT

Date: $10 / 18 / 2011$

Printed Name: Thomas A. Thicle (or designee) 
CAU 372: AREA 20 CABRIOLET/PALANQUIN UNIT CRATERS 
THIS PAGE INTENTIONALLY LEFT BLANK 


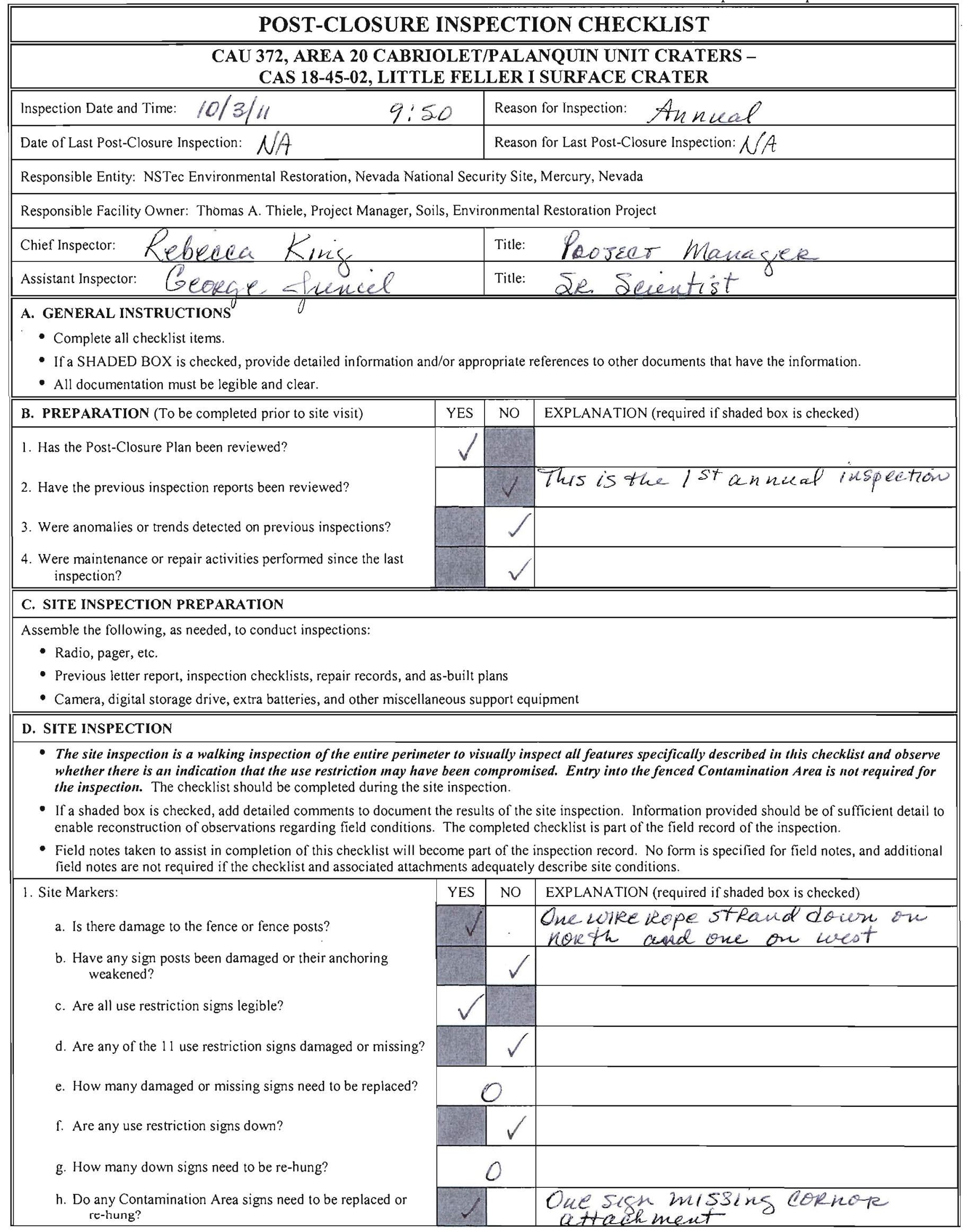




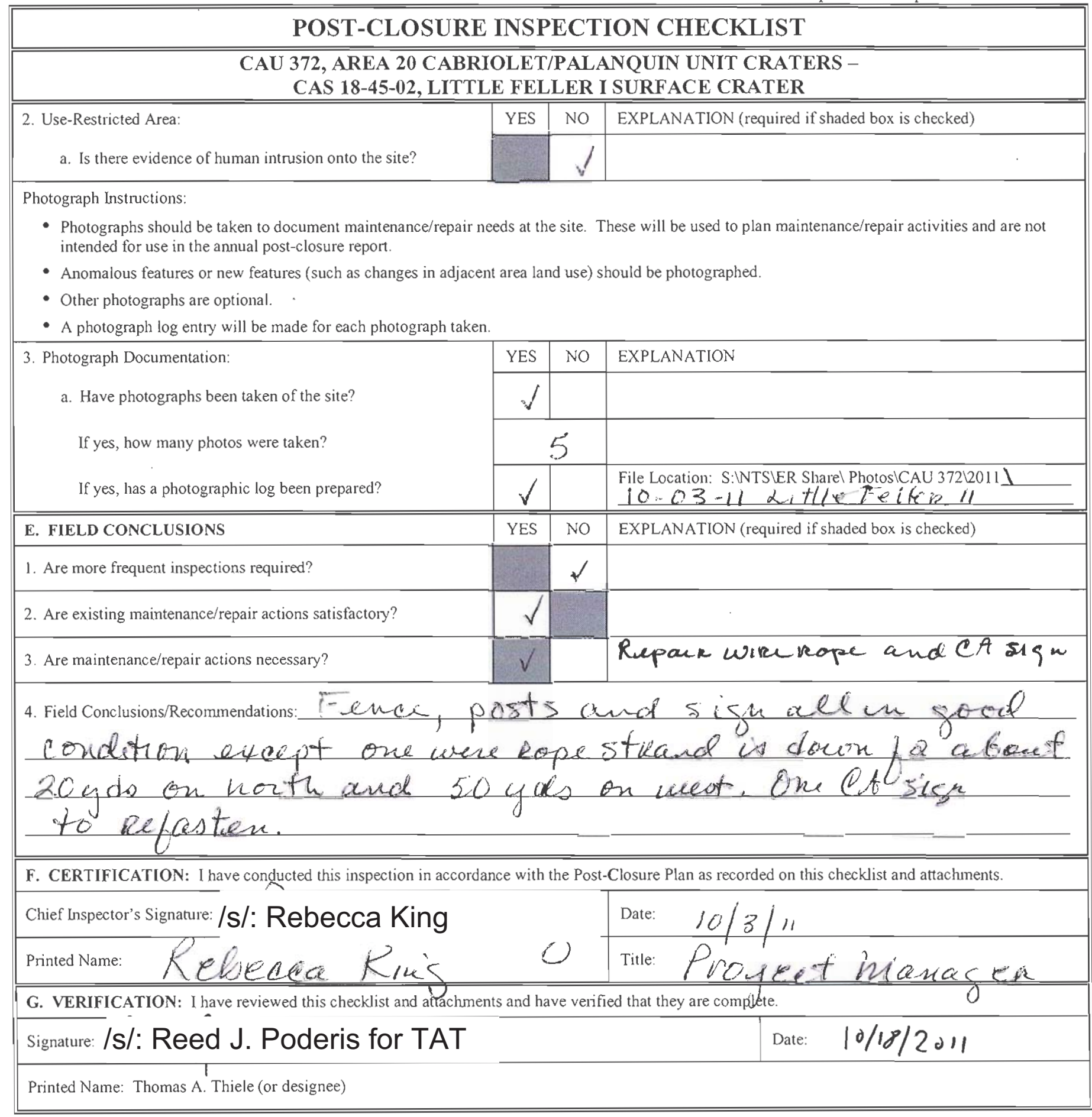




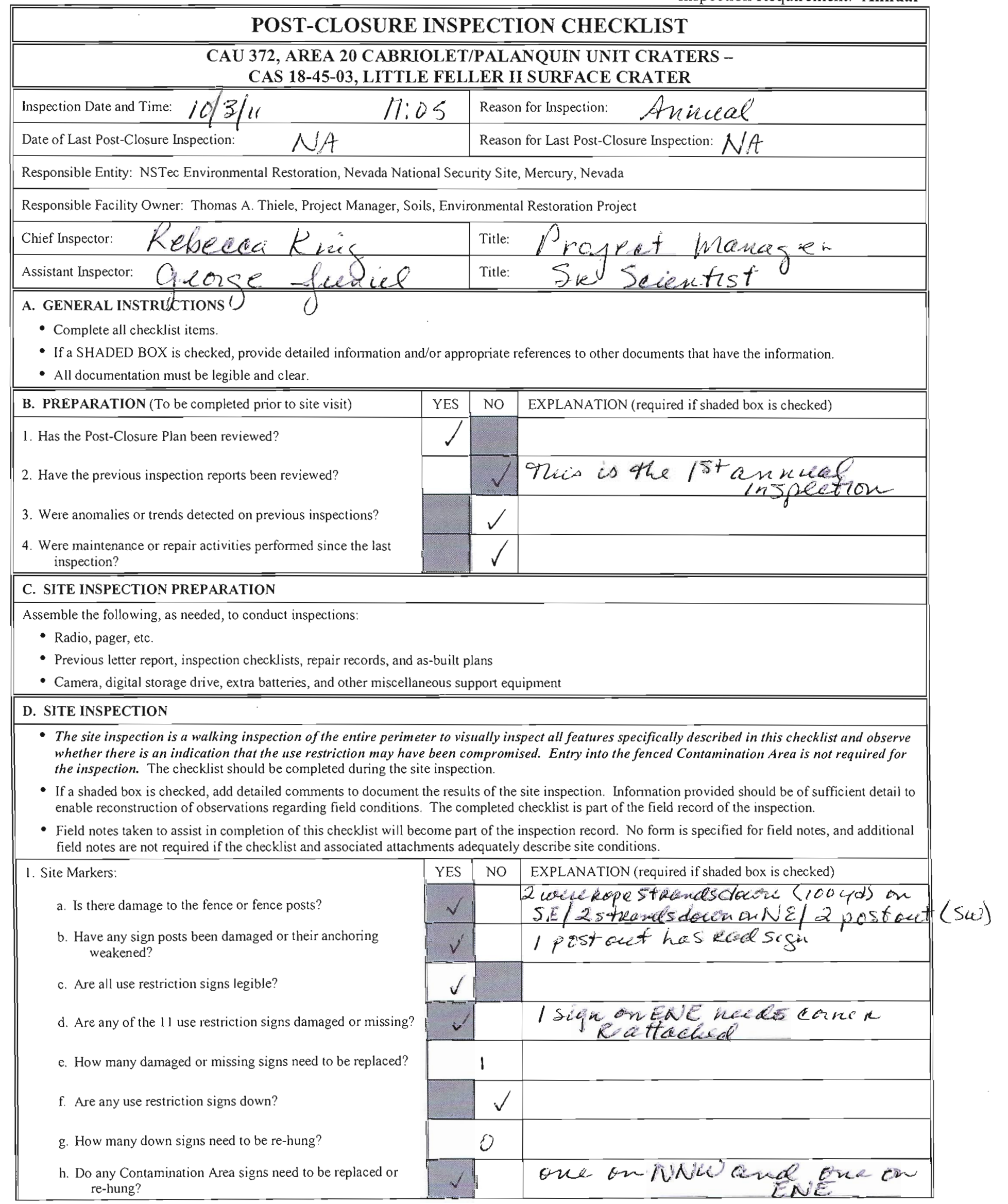




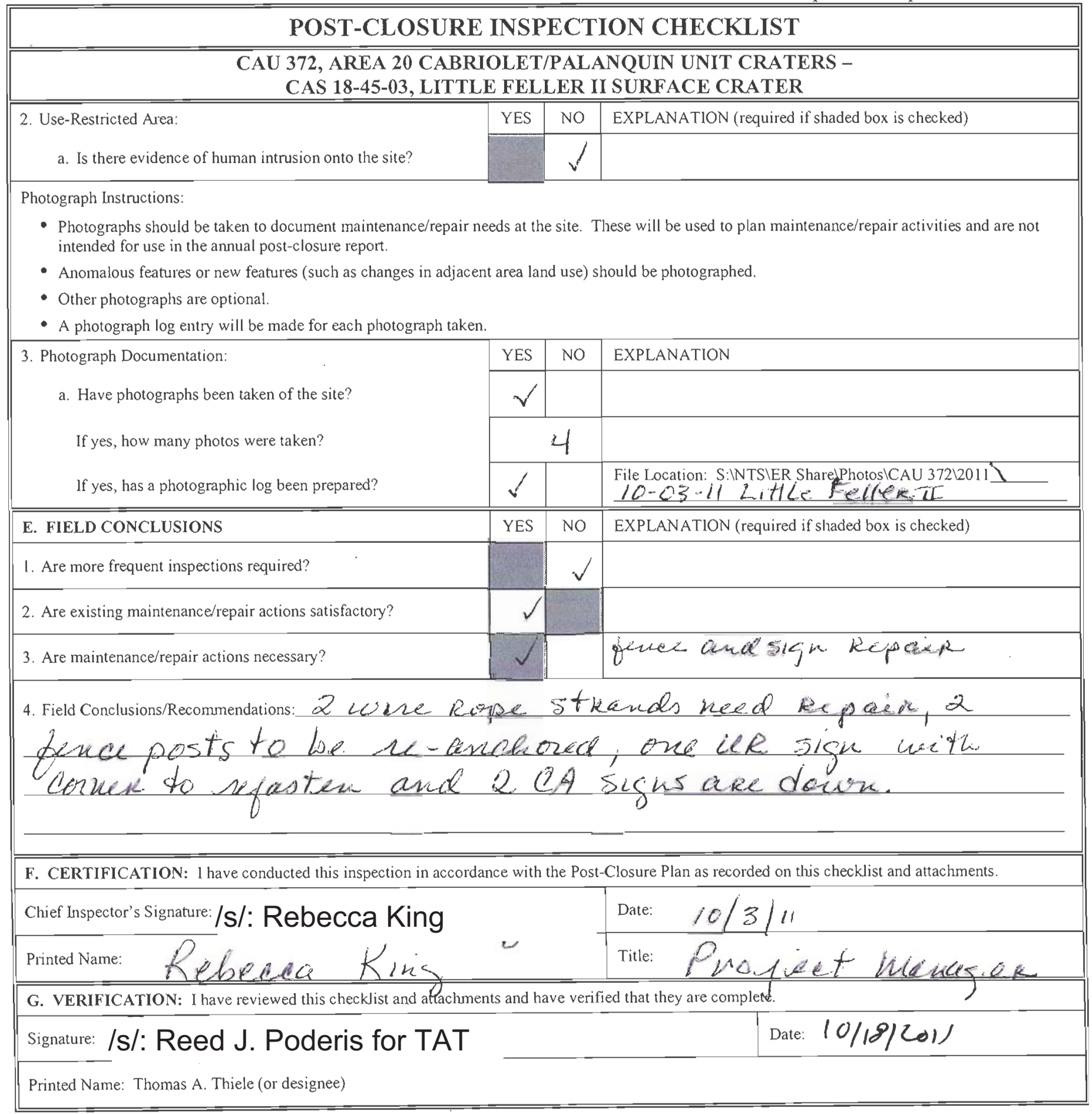




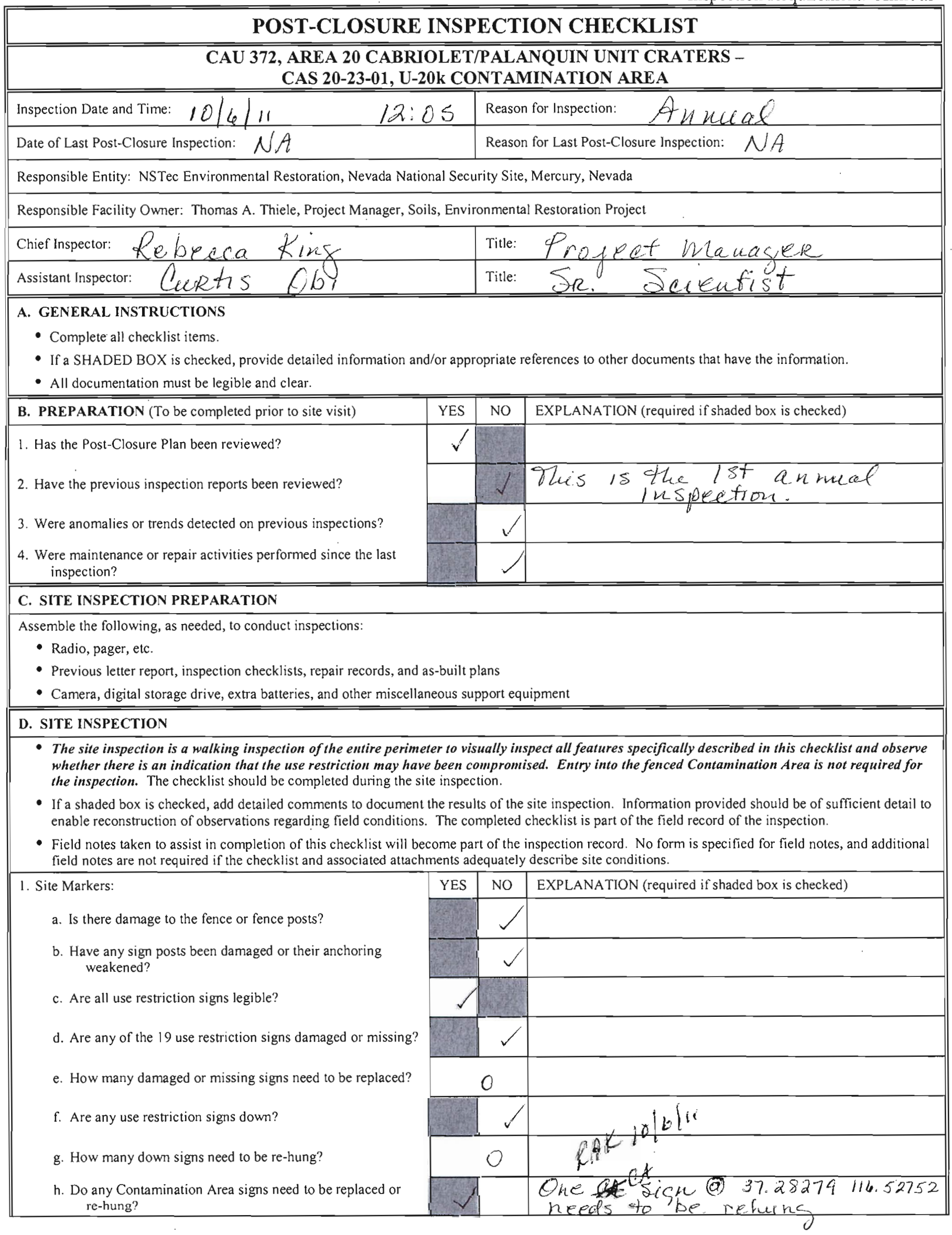




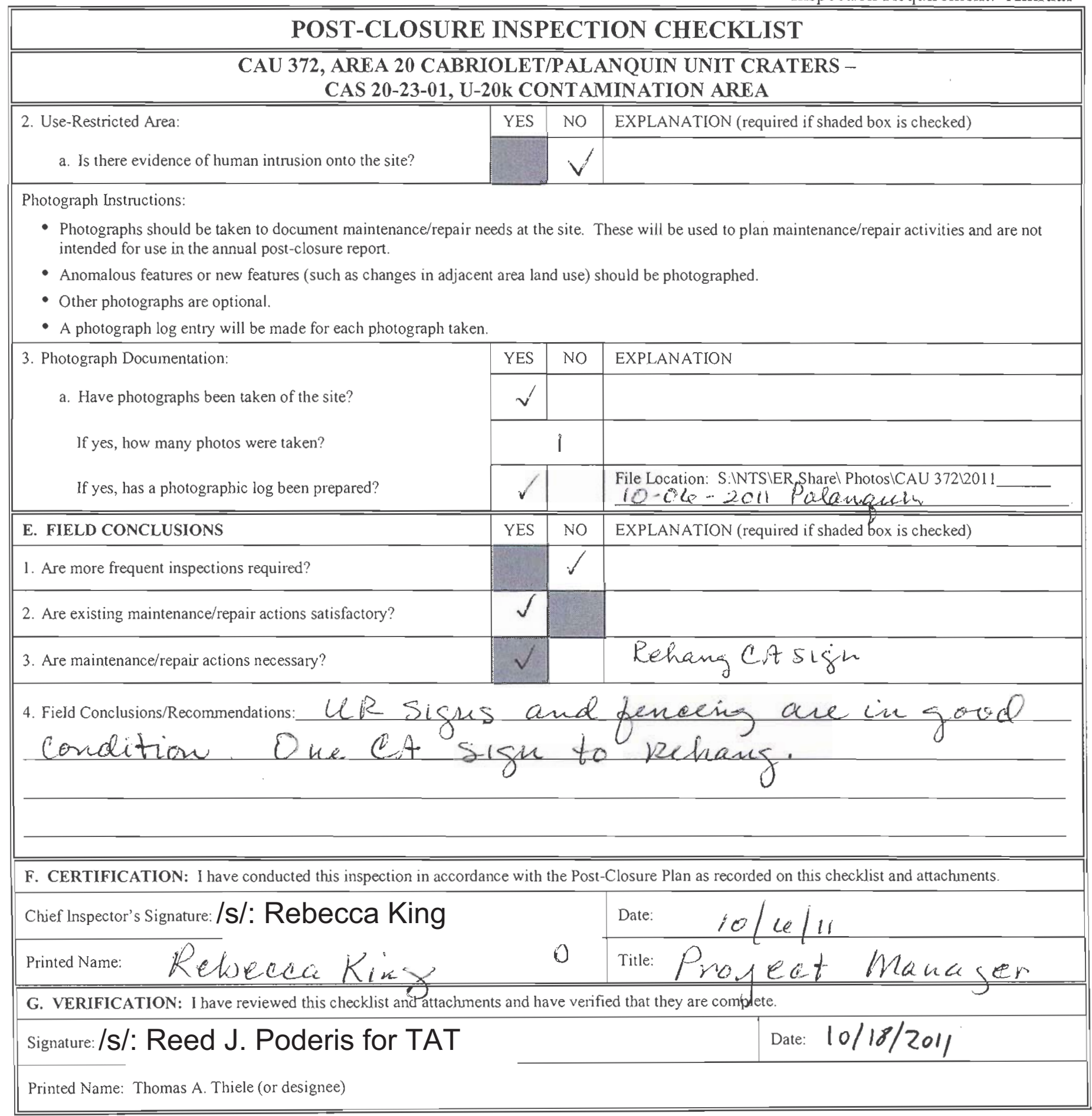




\begin{tabular}{|c|c|}
\hline \multicolumn{2}{|c|}{ POST-CLOSURE INSPECTION CHECKLIST } \\
\hline \multicolumn{2}{|c|}{$\begin{array}{l}\text { CAU 372, AREA } 20 \text { CABRIOLET/PALANQUIN UNIT CRATERS - } \\
\text { CAS 20-45-01, U-20L CRATER (CABRIOLET) } \\
\end{array}$} \\
\hline Inspection Date and Time: $10 / 6 / 11$ & Reason for Inspection: An nuel \\
\hline Date of Last Post-Closure Inspection: & Reason for Last Post-Closure Inspection: NA \\
\hline \multicolumn{2}{|c|}{ Responsible Entity: NSTec Environmental Restoration, Nevada National Security Site, Mercury, Nevada } \\
\hline \multicolumn{2}{|c|}{ Responsible Facility Owner: Thomas A. Thiele, Project Manager, Soils, Environmental Restoration Project } \\
\hline Chief Inspector: Rebecea & 12arasere \\
\hline Assistant Inspector: $\quad(P$ R $R 75$ & Title: Sk Scienctisto \\
\hline
\end{tabular}

\section{A. GENERAL INSTRUCTIONS}

- Complete all checklist items.

- If a SHADED BOX is checked, provide detailed information and/or appropriate references to other documents that have the information.

- All documentation must be legible and clear.

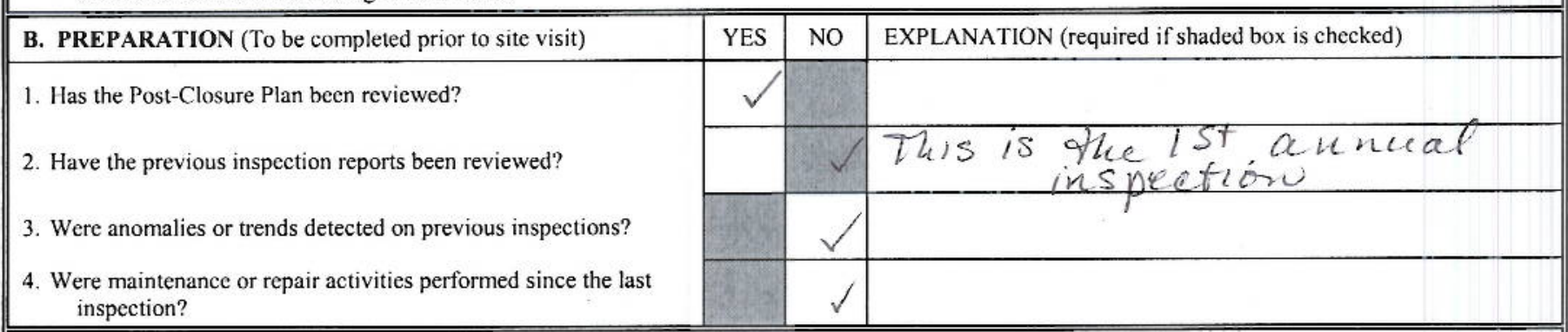

\section{SITE INSPECTION PREPARATION}

Assemble the following, as needed, to conduct inspections:

- Radio, pager, etc.

- Previous letter report, inspection checklists, repair records, and as-built plans

- Camera, digital storage drive, extra batteries, and other miscellaneous support equipment

\section{SITE INSPECTION}

- The site inspection is a walking inspection of the entire perimeter to visually inspect all features specifically described in this checklist and observe whether there is an indication that the use restriction may have been compromised. Entry into the fenced Contamination Area is not required for the inspection. The checklist should be completed during the site inspection.

- If a shaded box is checked, add detailed comments to document the results of the site inspection. Information provided should be of sufficient detail to enable reconstruction of observations regarding field conditions. The completed checklist is part of the field record of the inspection.

- Field notes taken to assist in completion of this checklist will become part of the inspection record. No form is specified for field notes, and additional field notes are not required if the checklist and associated attachments adequately describe site conditions.

1. Site Markers:

a. Is there damage to the fence or fence posts?

b. Have any sign posts been damaged or their anchoring weakened?

c. Are all use restriction signs legible?

d. Are any of the 16 use restriction signs damaged or missing?

e. How many damaged or missing signs need to be replaced?

f. Are any use restriction signs down?

g. How many down signs need to be re-hung?

h. Do any Contamination Area signs need to be replaced or re-hung?

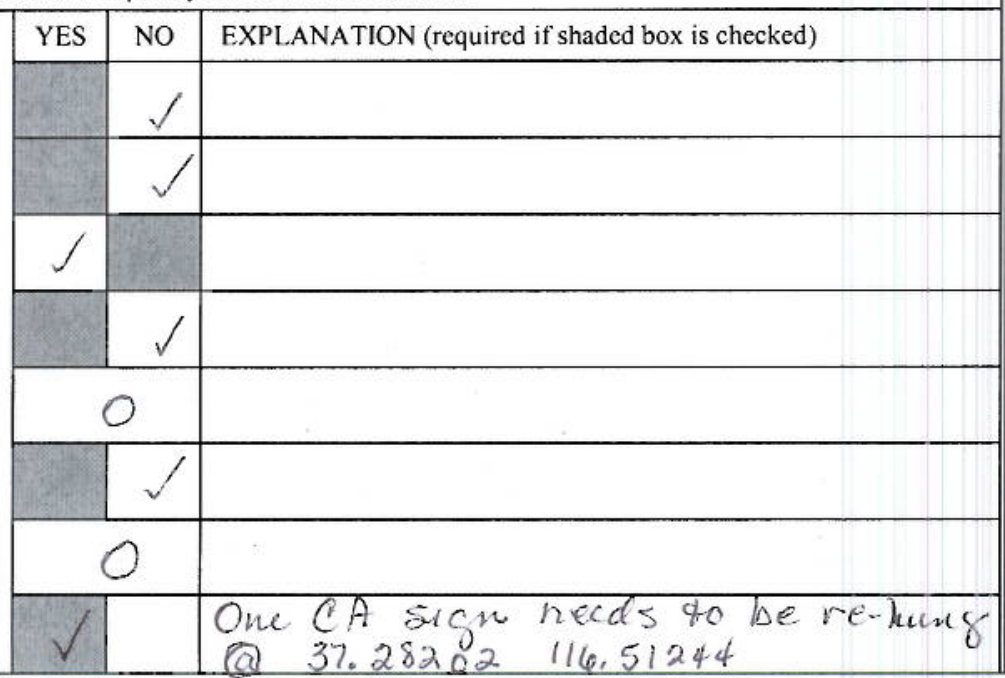




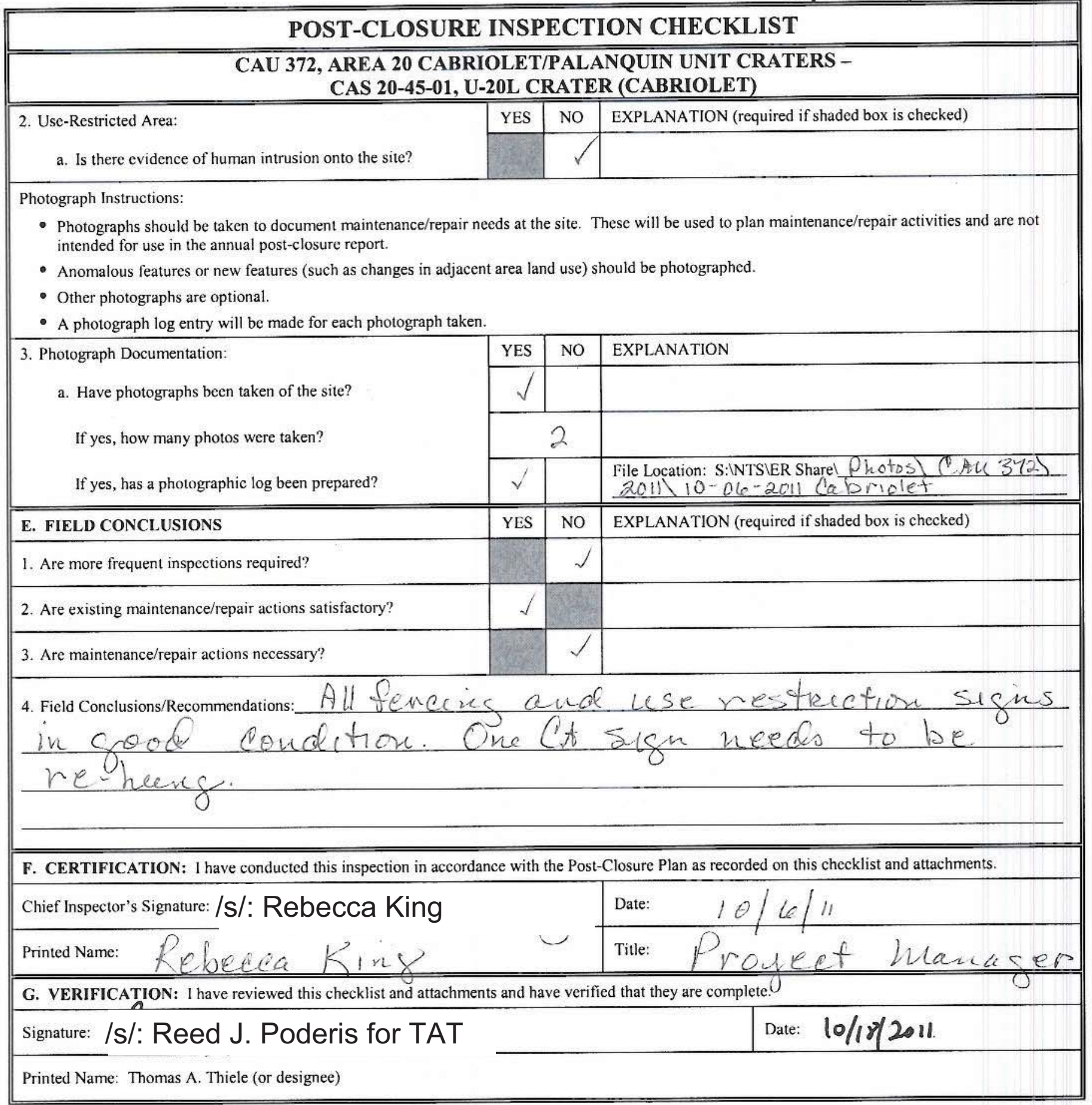


CAU 374: AREA 20 SCHOONER UNIT CRATER 
THIS PAGE INTENTIONALLY LEFT BLANK 


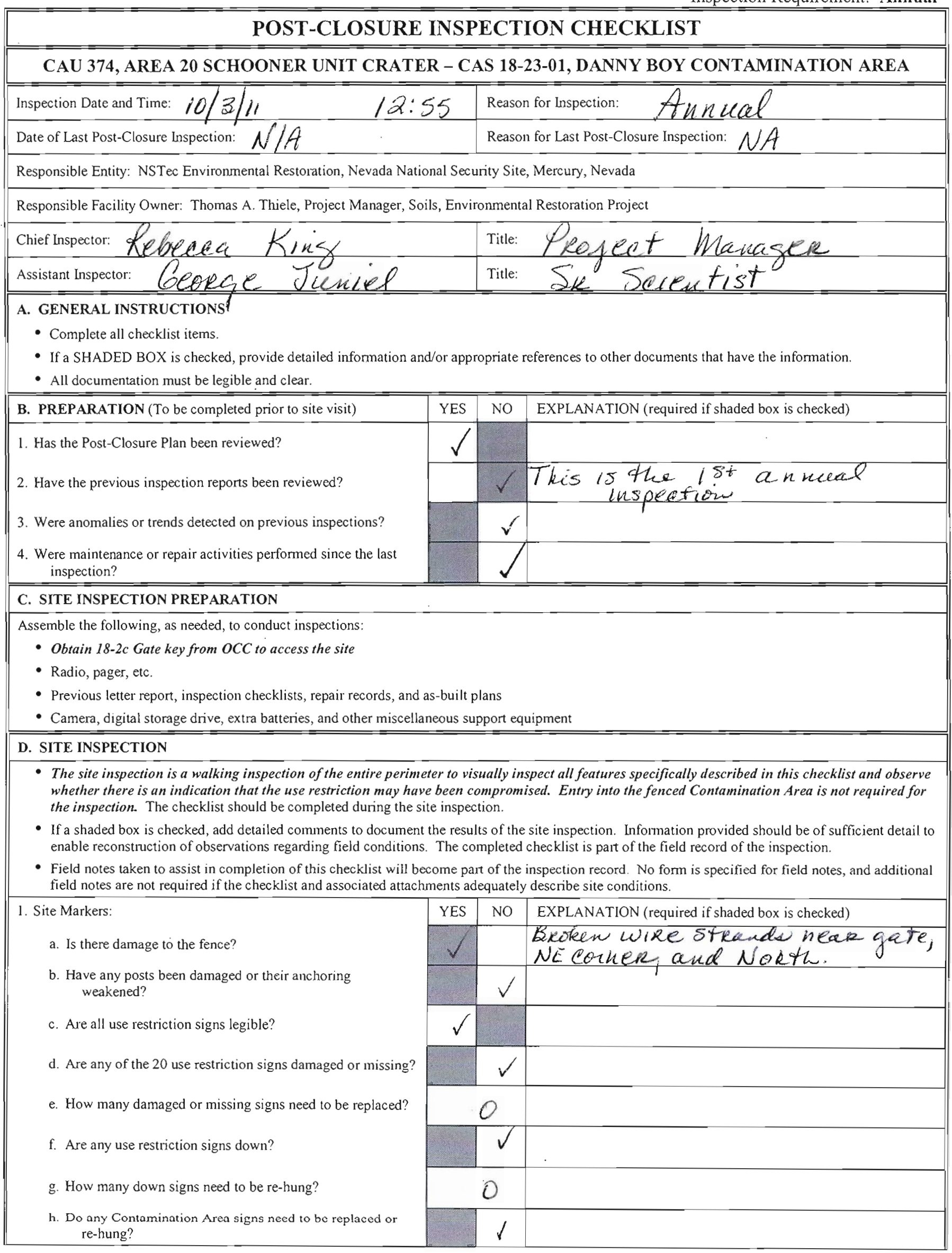




\section{POST-CLOSURE INSPECTION CHECKLIST}

\section{CAU 374, AREA 20 SCHOONER UNIT CRATER - CAS 18-23-01, DANNY BOY CONTAMINATION AREA}

\begin{tabular}{|l|c|c|c|}
\hline & & & \\
\hline 2. Use-Restricted Area: & YES & NO & EXPLANATION (required if shaded box is checked) \\
\cline { 2 - 4 } \\
a. Is there evidence of human intrusion onto the site?
\end{tabular}

Photograph Instructions:

- Photographs should be taken to document maintenance/repair needs at the site. These will be used to plan maintenance/repair activities and are not intended for use in the annual post-closure report.

- Anomalous features or new features (such as changes in adjacent area land use) should be photographed.

- Other photographs are optional.

- A photograph log entry will be made for each photograph taken.

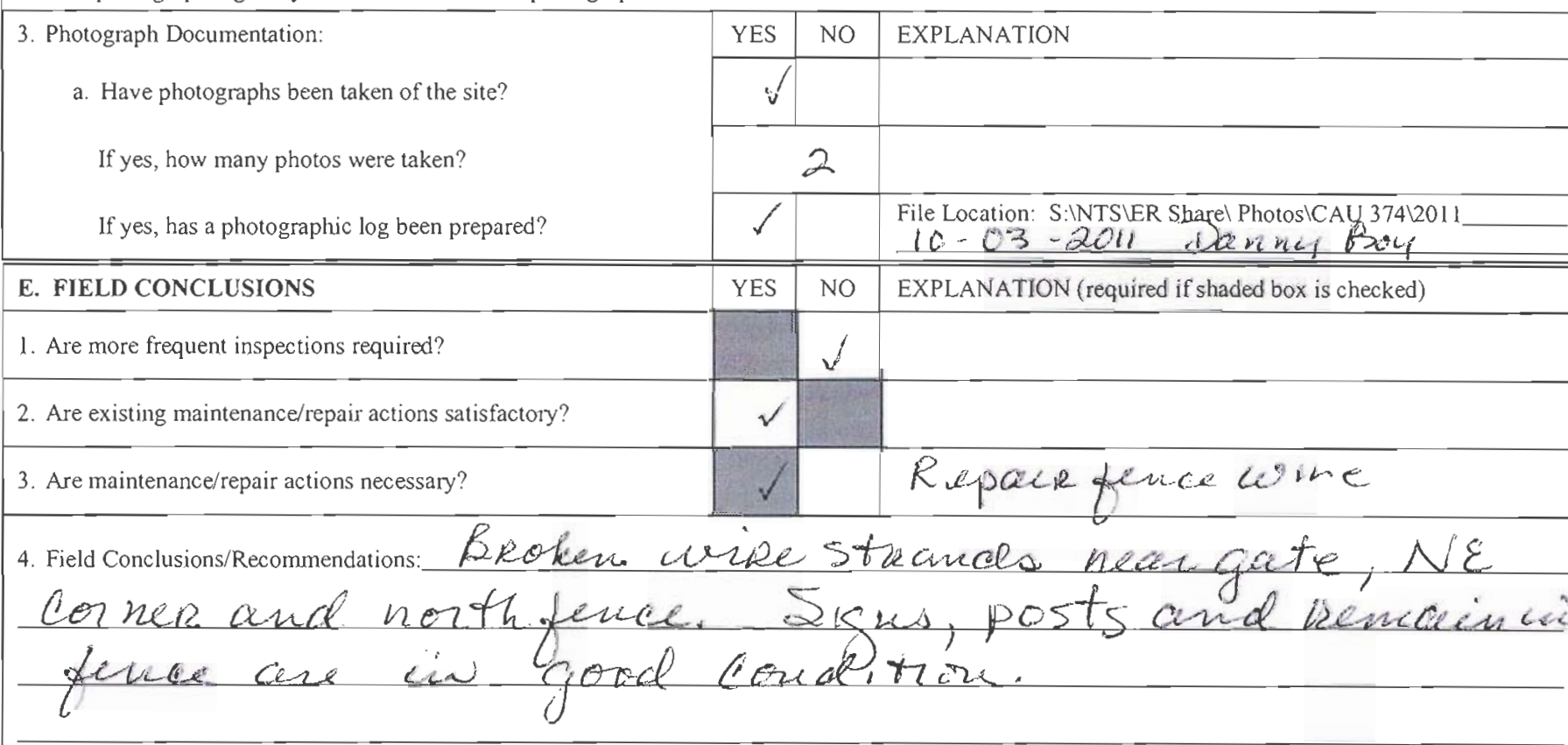

F. CERTIFICATION: I have conducted this inspection in accordance with the Post-Closure Plan as recorded on this checklist and attachments.

Chief Inspector's Signature: /s/: Rebecca King

Printed Name: Rebecea King $\circlearrowleft$

G. VERIFICATION: I have reviewed this checklist and attokhments and have verified that they are complete.

Signature: /s/: Reed J. Poderis for TAT

Date: $10 / 18 / 2011$

Printed Name: Thomas A. Thiele (or designee) 


\begin{tabular}{|c|c|c|c|c|}
\hline \multicolumn{5}{|c|}{ POST-CLOSURE INSPECTION CHECKLIST } \\
\hline \multicolumn{5}{|c|}{ CAU 374, AREA 20 SCHOONER UNIT CRATER - CAS 20-45-03, U-20u CRATER (SCHOONER) } \\
\hline Inspection Date and Time: $10 / 6 / 11$ & $10: 00$ & \multicolumn{3}{|c|}{ Reason for Inspection: की $114 \mathrm{Lal}$} \\
\hline \multicolumn{2}{|l|}{ Date of Last Post-Closure Inspection: $N A$} & \multicolumn{3}{|c|}{ Reason for Last Post-Closure Inspection: $N A$} \\
\hline \multicolumn{5}{|c|}{ Responsible Entity: NSTec Environmental Restoration, Nevada National Security Site, Mercury, Nevada } \\
\hline \multicolumn{5}{|c|}{ Responsible Facility Owner: Thomas A. Thiele, Project Manager, Soils, Environmental Restoration Project } \\
\hline \multicolumn{2}{|l|}{ Chief Inspector: Febecca Kins } & \multicolumn{3}{|c|}{ Title: PROTEQT WANAGER } \\
\hline \multicolumn{2}{|l|}{ 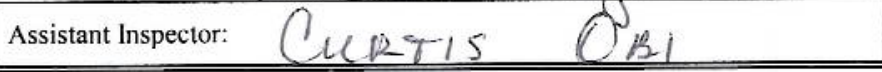 } & \multicolumn{3}{|c|}{ Title: SR. SC1ENT1S7 } \\
\hline \multicolumn{5}{|c|}{$\begin{array}{l}\text { A. GENERAL INSTRUCTIONS } \\
\text { - Complete all checklist items. } \\
\text { - If a SHADED BOX is checked, provide detailed information and/or appropriate references to other documents that have the information. } \\
\text { - All documentation must be legible and clear. }\end{array}$} \\
\hline B. PREPARATION (To be completed prior to site visit) & YES & NO & EXPLANATION (required if shaded box is checked) & \\
\hline \multirow{4}{*}{$\begin{array}{l}\text { 1. Has the Post-Closure Plan been reviewed? } \\
\text { 2. Have the previous inspection reports been reviewed? } \\
\text { 3. Were anomalies or trends detected on previous inspections? } \\
\text { 4. Were maintenance or repair activities performed since the last } \\
\text { inspection? }\end{array}$} & & & & \\
\hline & & & $\begin{array}{l}\text { This is the .lst an } \\
\text { inspection }\end{array}$ & wera \\
\hline & & & & \\
\hline & & & & \\
\hline \multicolumn{5}{|l|}{ C. SITE INSPECTION PREPARATION } \\
\hline \multicolumn{5}{|c|}{$\begin{array}{l}\text { Assemble the following, as needed, to conduct inspections: } \\
\text { - Radio, pager, etc. } \\
\text { - Previous letter report, inspection checklists, repair records, and as-built plans } \\
\text { - Camera, digital storage drive, extra batteries, and other miscellaneous support equipment }\end{array}$} \\
\hline \multicolumn{5}{|l|}{ D. SITE INSPECTION } \\
\hline \multicolumn{5}{|c|}{$\begin{array}{l}\text { - The site inspection is a walking inspection of the entire perimeter to visually inspect all features specifically described in this checklist and observe } \\
\text { whether there is an indication that the use restriction may have been compromised. Entry into the use-restricted area is not required for the } \\
\text { inspection. The checklist should be completed during the site inspection. } \\
\text { - If a shaded box is checked, add detailed comments to document the results of the site inspection. Information provided should be of suflicient detail to } \\
\text { enable reconstruction of observations regarding field conditions. The completed checklist is part of the field record of the inspection. } \\
\text { - Field notes taken to assist in completion of this checklist will become part of the inspection record. No form is specified for field notes, and additional } \\
\text { field notes are not required if the checklist and associated attachments adequately describe site conditions. }\end{array}$} \\
\hline \multirow{2}{*}{$\begin{array}{l}\text { 1. Site Markers: } \\
\text { a. Have any sign posts been damaged or their anchoring } \\
\text { weakened? }\end{array}$} & YES & NO & EXPLANATION (required if shaded box is checked) & \\
\hline & & & & \\
\hline \multicolumn{5}{|l|}{ b. Are all use restriction signs legible? } \\
\hline \multicolumn{5}{|l|}{ c. Are any of the 18 use restriction signs damaged or missing? } \\
\hline \multicolumn{5}{|l|}{ d. How many damaged or missing signs need to be replaced? } \\
\hline \multicolumn{5}{|l|}{ e. Are any use restriction signs down? } \\
\hline f. How many down signs need to be re-hung? & \multicolumn{2}{|r|}{0} & & \\
\hline g. Does the historical sign need to be replaced or re-hung? & & & & \\
\hline \multirow{2}{*}{$\begin{array}{l}\text { 2. Use-Restricted Area: } \\
\text { a. Is there evidence of human intrusion onto the site? }\end{array}$} & YES & NO & EXPLANATION (required if shaded box is checked) & \\
\hline & & & & \\
\hline
\end{tabular}




\section{POST-CLOSURE INSPECTION CHECKLIST}

\section{CAU 374, AREA 20 SCHOONER UNIT CRATER - CAS 20-45-03, U-20u CRATER (SCHOONER)}

Photograph Instructions:

- Photographs should be taken to document maintenance/repair needs at the site. These will be used to plan maintenance/repair activities and are not intended for use in the annual post-closure report.

- Anomalous features or new features (such as changes in adjacent area land use) should be photographed.

- Other photographs are optional.

- A photograph log entry will be made for each photograph taken.

\begin{tabular}{|c|c|c|c|}
\hline \multirow{2}{*}{$\begin{array}{l}\text { 3. Photograph Documentation: } \\
\text { a. Have photographs been taken of the site? }\end{array}$} & YES & NO & EXPLANATION \\
\hline & & & \\
\hline If yes, how many photos were taken? & & 1 & \\
\hline If yes, has a photographic log been prepared? & & & 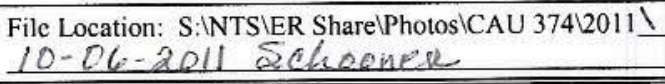 \\
\hline E. FIELD CONCIUSIONS & YES & NO & EXPLANATION (required if shaded box is checked) \\
\hline 1. Are more frequent inspections required? & & & \\
\hline 2. Are existing maintenance/repair actions satisfactory & & & \\
\hline 3. Are maintenance/repair actions necessary? & & & \\
\hline 4. Field Conclusions/Recommendations: It & & & are $1, c$ \\
\hline
\end{tabular}

F. CERTIFICATION: I have conducted this inspection in accordance with the Post-Closure Plan as recorded on this checklist and attachments.

Chief Inspector's Signature: /s/: Rebecca King

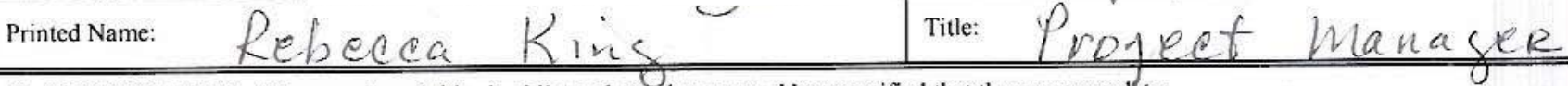
G. VERIFICATION: I have reviewed this checklist and attachments and have verified that they are complete. Signature: /s/: Reed J. Poderis for TAT Date: $10 / 18 / 200$

Printed Name: Thomas A. Thiele (or designee) 
CAU 375: AREA 30 BUGGY UNIT CRATERS 
THIS PAGE INTENTIONALLY LEFT BLANK 


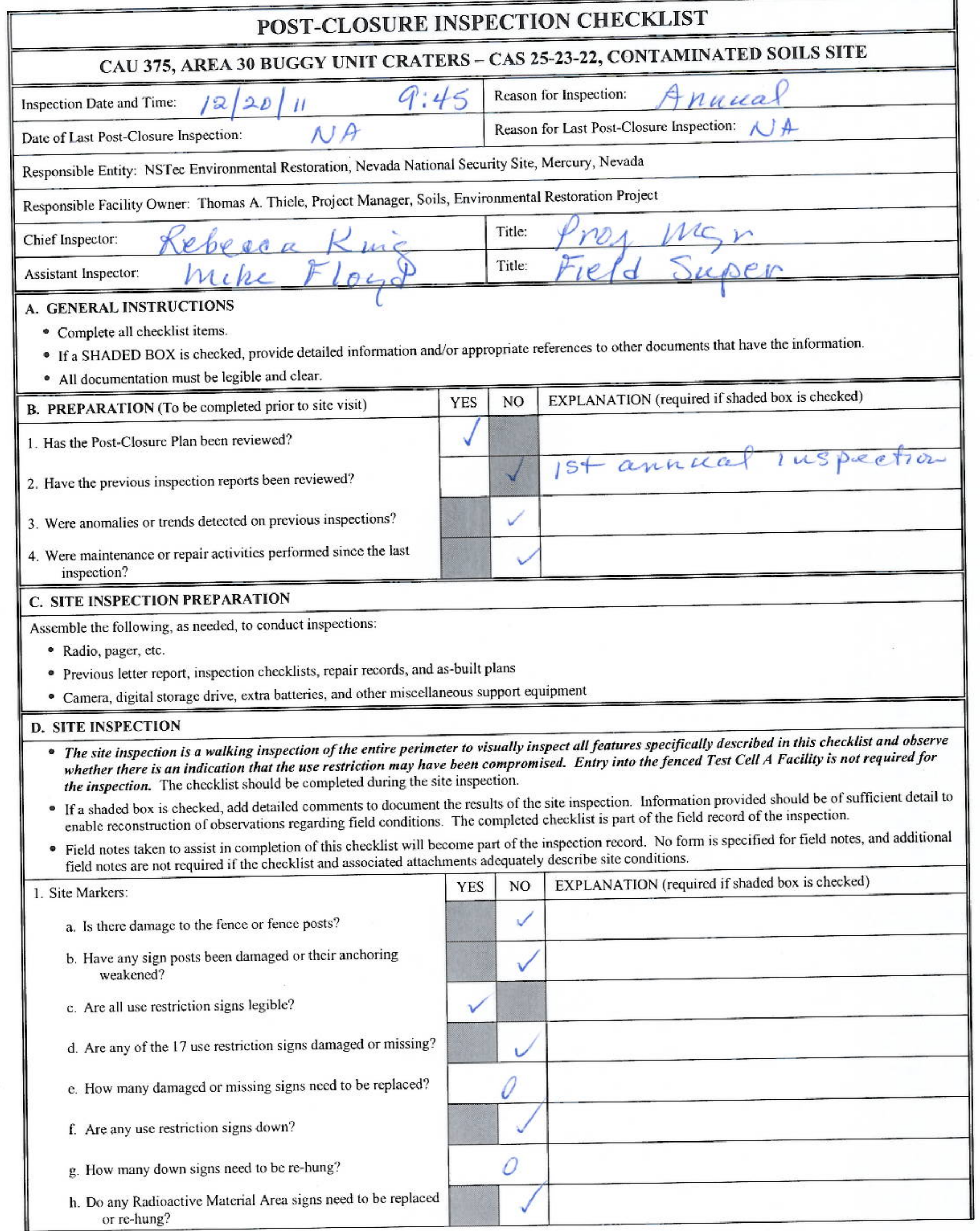


POST-CLOSURE INSPECTION CHECKLIST

\section{CAU 375, AREA 30 BUGGY UNIT CRATERS - CAS 25-23-22, CONTAMINATED SOILS SITE}

\section{Use-Restricted Area:}

a. Is there evidence of human intrusion onto the site?

Photograph Instructions:

- Photographs should be taken to document maintenance/repair needs at the site. These will be used to plan maintenance/repair activities and are not intended for use in the annual post-closure report.

- Anomalous features or new features (such as changes in adjacent area land use) should be photographed.

- Other photographs are optional.

- A photograph log entry will be made for each photograph taken.

3. Photograph Documentation:

a. Have photographs been taken of the site?

If yes, how many photos were taken?

If yes, has a photographic log been prepared?

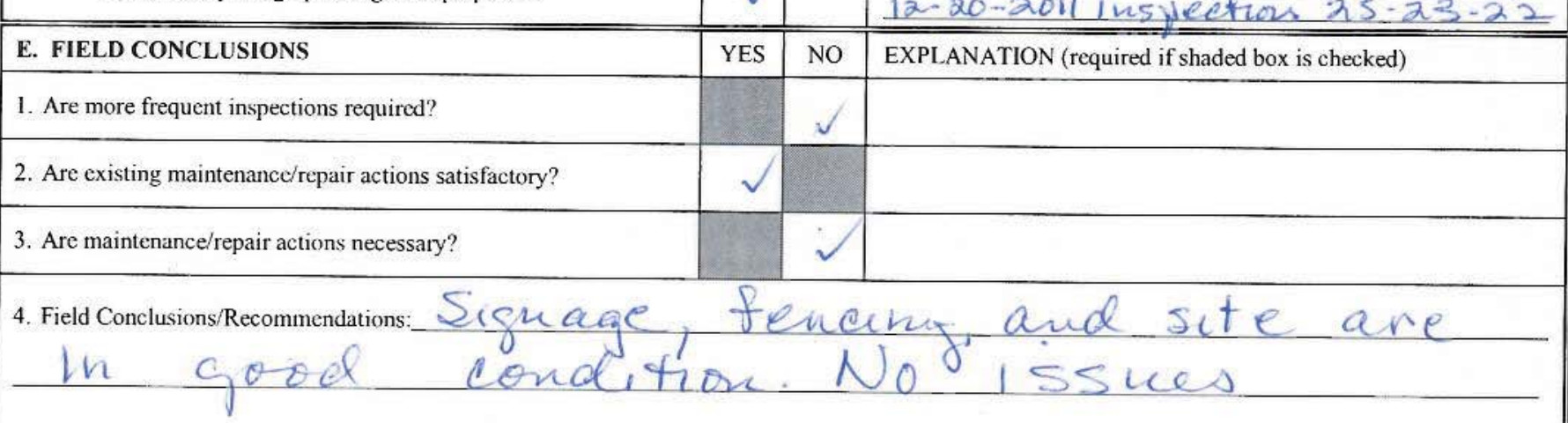

F. CERTIFICATION: I have conducted this inspection in accordance with the Post-Closure Plan as recorded on this checklist and attachments.

Chief Inspector's Signature: /s/: Rebecca King

Printed Name:
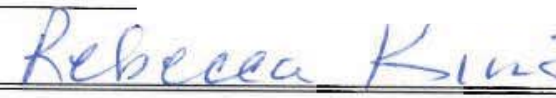

G. VERIFICATIO

Signature: /s/: Reed J. Poderis for TAT

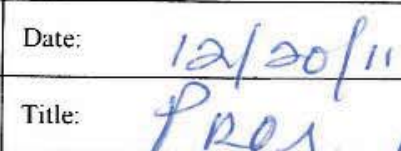

ROA

Date: $1 / 3 / 207$

Printed Name: Thomas A. Thiele (or designee) 


\section{POST-CLOSURE INSPECTION CHECKLIST}

\section{CAU 375, AREA 30 BUGGY UNIT CRATERS - CAS 30-45-01, U-30a, b, c, d, e CRATERS}

\begin{tabular}{|ll|l|l}
\hline \hline Inspection Date and Time: $10 / 3 / 1$ & $2: 40$ & Reason for Inspection: Anual \\
\hline Date of Last Post-Closure Inspection: NA & Reason for Last Post-Closure Inspection: NA \\
\hline
\end{tabular}

Responsible Entity: NSTec Environmental Restoration, Nevada National Security Site, Mercury, Nevada

Responsible Facility Owner: Thomas A. Thiele, Project Manager, Soils, Environmental Restoration Project

\begin{tabular}{|c|c|}
\hline Chief Inspector: Rebecaa Kinc & Title: PRopeef Manasie \\
\hline Assistant Inspector: (oeonge Jun iel & Title: Sie. Sesientist \\
\hline
\end{tabular}

A. GENERAL INSTRUCTIONS

- Complete all checklist items.

- If a SHADED BOX is checked, provide detailed information and/or appropriate references to other documents that have the information.

- All documentation must be legible and clear.

\begin{tabular}{|c|c|c|c|}
\hline B. PREPARATION (To be completed prior to site visit) & YES & NO & EXPLANATION (required if shaded box is checked) \\
\hline \multicolumn{4}{|l|}{ 1. Has the Post-Closure Plan been reviewed? } \\
\hline 2. Have the previous inspection reports been reviewed? & & & $\begin{array}{c}\text { NA 9his is the lst a nnual } \\
\text { inspeetion }\end{array}$ \\
\hline 3. Were anomalies or trends detected on previous inspections? & & & \\
\hline $\begin{array}{l}\text { 4. Were maintenance or repair activities performed since the last } \\
\text { inspection? }\end{array}$ & & & \\
\hline
\end{tabular}

\section{SITE INSPECTION PREPARATION}

Assemble the following, as needed, to conduct inspections:

- Obtain key from OCC to access Cat Canyon Road

- Radio, pager, etc.

- Previous letter report, inspection checklists, repair records, and as-built plans

- Camera, digital storage drive, extra batteries, and other miscellaneous support equipment

\section{SITE INSPECTION}

- The site inspection is a walking inspection of the entire perimeter to visually inspect all features specifically described in this checklist and observe whether there is an indication that the use restriction may have been compromised. Entry into the fenced Contamination Area is not required for the inspection. The checklist should be completed during the site inspection.

- If a shaded box is checked, add detailed comments to document the results of the site inspection. Information provided should be of sufficient detail to enable reconstruction of observations regarding field conditions. The completed checklist is part of the field record of the inspection.

- Field notes taken to assist in completion of this checklist will become part of the inspection record. No form is specified for field notes, and additional field notes are not required if the checklist and associated attachments adequately describe site conditions.

\begin{tabular}{|c|c|c|c|}
\hline I. Site Markers: & YES & NO & EXPLANATION (required if shaded box is checked) \\
\hline a. Is there damage to the fence or fence posts? & $\checkmark$ & & $\begin{array}{l}\text { I wrie stand isdocin ance I } \\
\text { post needs reanchorixs and }\end{array}$ \\
\hline $\begin{array}{l}\text { b. Have any sign posts been damaged or their anchoring } \\
\text { weakened? }\end{array}$ & & $\checkmark$ & kew wore \\
\hline c. Are all use restriction signs legible? & $v$ & & \\
\hline d. Are any of the 18 use restriction signs damaged or missing? & & 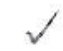 & \\
\hline c. How many damaged or missing signs need to be replaced? & & 0 & \\
\hline f. Are any use restriction signs down? & & $\checkmark$ & \\
\hline g. How many down signs need to be re-hung? & & 0 & \\
\hline $\begin{array}{l}\text { h. Do any Contamination Area signs need to be replaced or } \\
\text { re-hung? }\end{array}$ & & & \\
\hline
\end{tabular}




\section{POST-CLOSURE INSPECTION CHECKLIST}

\section{CAU 375, AREA 30 BUGGY UNIT CRATERS - CAS 30-45-01, U-30a, b, c, d, e CRATERS}

2. Use-Restricted Area:

a. Is there evidence of human intrusion onto the site?

\begin{tabular}{|c|c|c|c|}
\hline YES & NO & EXPLANATION (required if shaded box is checked) \\
\hline & $\sqrt{ }$ & \\
\end{tabular}

Photograph Instructions:

- Photographs should be taken to document maintenance/repair needs at the site. These will be used to plan maintenance/repair activities and are not intended for use in the annual post-closure report.

- Anomalous features or new features (such as changes in adjacent area land use) should be photographed.

- Other photographs are optional.

- A photograph log entry will be made for each photograph taken.

3. Photograph Documentation:

a. Have photographs been taken of the site?

If yes, how many photos were taken?

If yes, has a photographic log been prepared?

\begin{tabular}{|c|c|c|}
\hline YES & NO & EXPLANATION \\
\hline & & \\
\hline & & 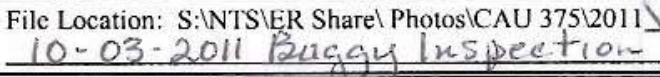 \\
\hline YES & NO & EXPLANATION (required if shaded box is checked) \\
\hline & & \\
\hline & & \\
\hline & & \\
\hline
\end{tabular}

3. Are maintenance/repair actions necessary?

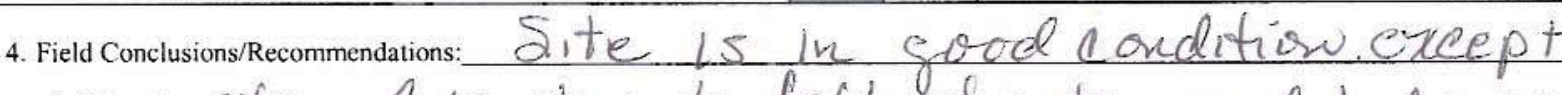
wire strand is dow to left of gate and I loose post up the hill and to Reght of gate.

F. CERTIFICATION: I have conducted this inspection in accordance with the Post-Closure Plan as recorded on this checklist and attachments.

Chief Inspector's Signature: /s/: Rebecca King

Printed Name:

Teloecea King

G. VERIFICATION: I have reviewed this checklist and attachments and have verified that they are complete.

Signature: /s/: Reed J. Poderis for TAT

Printed Name! Thomas A./Thiele (or designee)

Date: $10 / 3 / 1$

Date: $10 / 18 / 2011$ 


\section{CAU 383: AREA 12 E-TUNNEL SITES}


THIS PAGE INTENTIONALLY LEFT BLANK 


\begin{tabular}{||l|l||}
\hline \multicolumn{3}{|c||}{ POST-CLOSURE INSPECTION CHECKLIST } \\
\hline CAS 12-06-06, MUCKPILE, CAS 12-25-02, OIL SPILL, AND CAS 12-28-02, RADIOACTIVE MATERIAL \\
\hline Inspection Date and Time:
\end{tabular}

\begin{tabular}{||l|l|l|l||}
\hline \hline B. PREPARATION (To be completed prior to site visit) & YES & NO & EXPLANATION (required if shaded box is checked) \\
\hline 1. Has the Post-Closure Plan been reviewed? & & & \\
2. Have the previous inspection reports been reviewed? & & & \\
\cline { 2 - 5 } $\begin{array}{l}\text { 3. Were anomalies or trends detected on previous inspections? } \\
\text { 4. Were maintenance or repair activities performed since the last } \\
\text { inspection? }\end{array}$ & & & \\
\hline \hline C. SITE INSPECTION PREPARATION & &
\end{tabular}

Assemble the following, as needed, to conduct inspections:

- ER SKD66 key to access the sites

- Radio, pager, etc.

- Previous letter report, inspection checklists, repair records, and as-built plans

- Camera, digital storage drive, extra batteries, and other miscellaneous support equipment

\section{SITE INSPECTION}

- Visually inspect all features specifically described in this checklist and observe whether there is an indication that the use restriction may have been compromised. Entry into the use-restricted area is not required for the inspection. The checklist should be completed during the site inspection.

- If a shaded box is checked, add detailed comments to document the results of the site inspection. Information provided should be of sufficient detail to enable reconstruction of observations regarding field conditions. The completed checklist is part of the field record of the inspection.

- Field notes taken to assist in completion of this checklist will become part of the inspection record. No form is specified for field notes, and additional field notes are not required if the checklist and associated attachments adequately describe site conditions.

1. Site Markers:

a. Is there damage to the fence or fence posts?

b. Have any sign posts been damaged or their anchoring weakened?

c. Are all use restriction signs legible?

d. Are any of the 11 use restriction signs damaged or missing?

c. How many damaged or missing signs need to be replaced?

f. Are any use restriction signs down?

g. How many down signs need to be re-hung?

h. Do any Underground Radioactive Material Area signs need to be replaced or re-hung?

\begin{tabular}{|c|c|c|}
\hline YES & NO & EXPLANATION (required if shaded box is checked) \\
\hline$\sqrt{ }$ & & $\begin{array}{l}\text { Fence sthand doun botween } \\
\text { lst uR sich and gate }\end{array}$ \\
\hline & $\sqrt{ }$ & \\
\hline & & \\
\hline & $\checkmark v$ & \\
\hline & ) & \\
\hline $\bar{T}$ & & I siger dacen \\
\hline 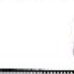 & & \\
\hline & $\checkmark$ & \\
\hline
\end{tabular}




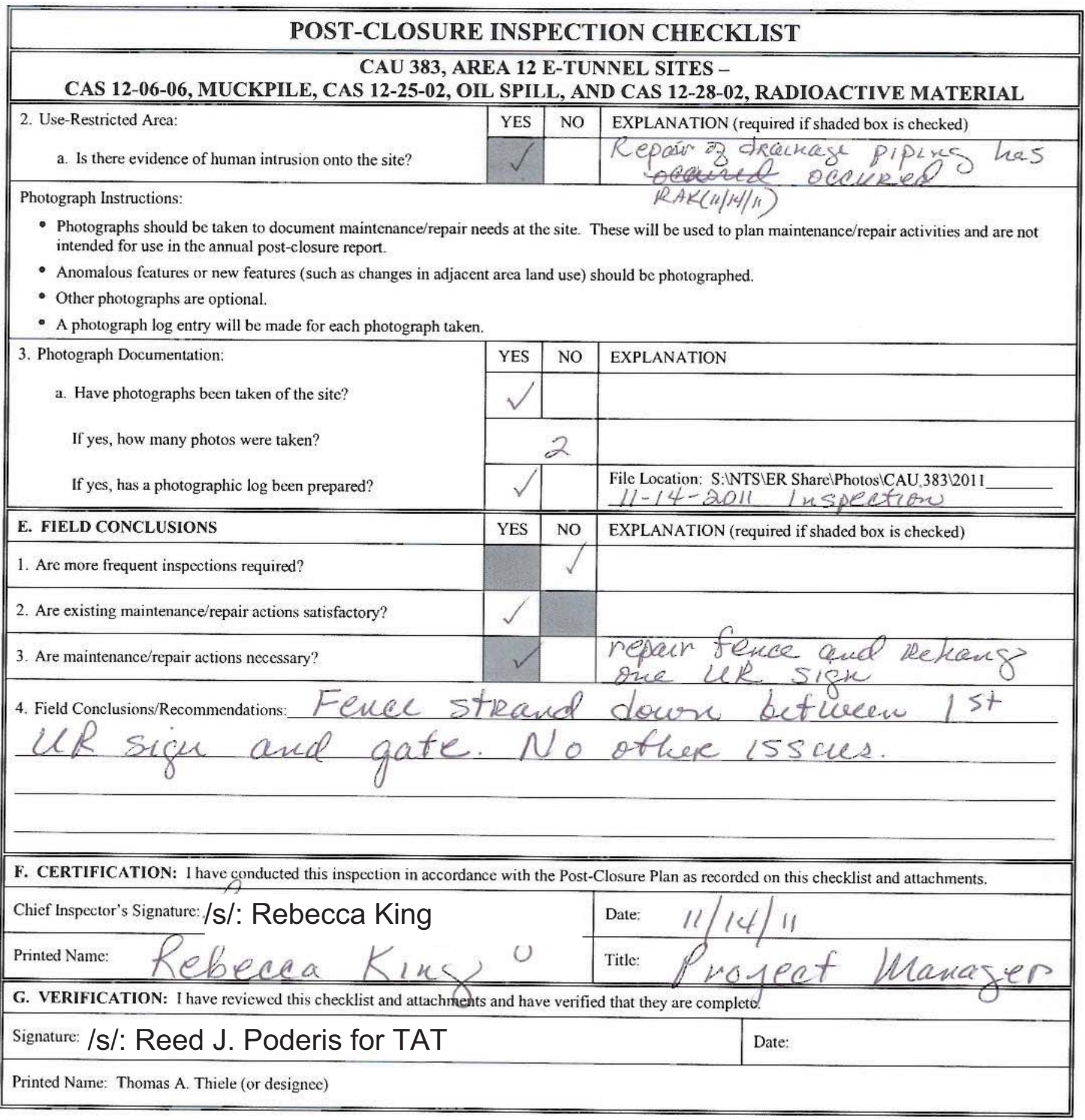




\section{CAU 476: AREA 12 T-TUNNEL MUCKPILE and CAU 559: T-TUNNEL COMPRESSOR/BLOWER PAD}


THIS PAGE INTENTIONALLY LEFT BLANK 


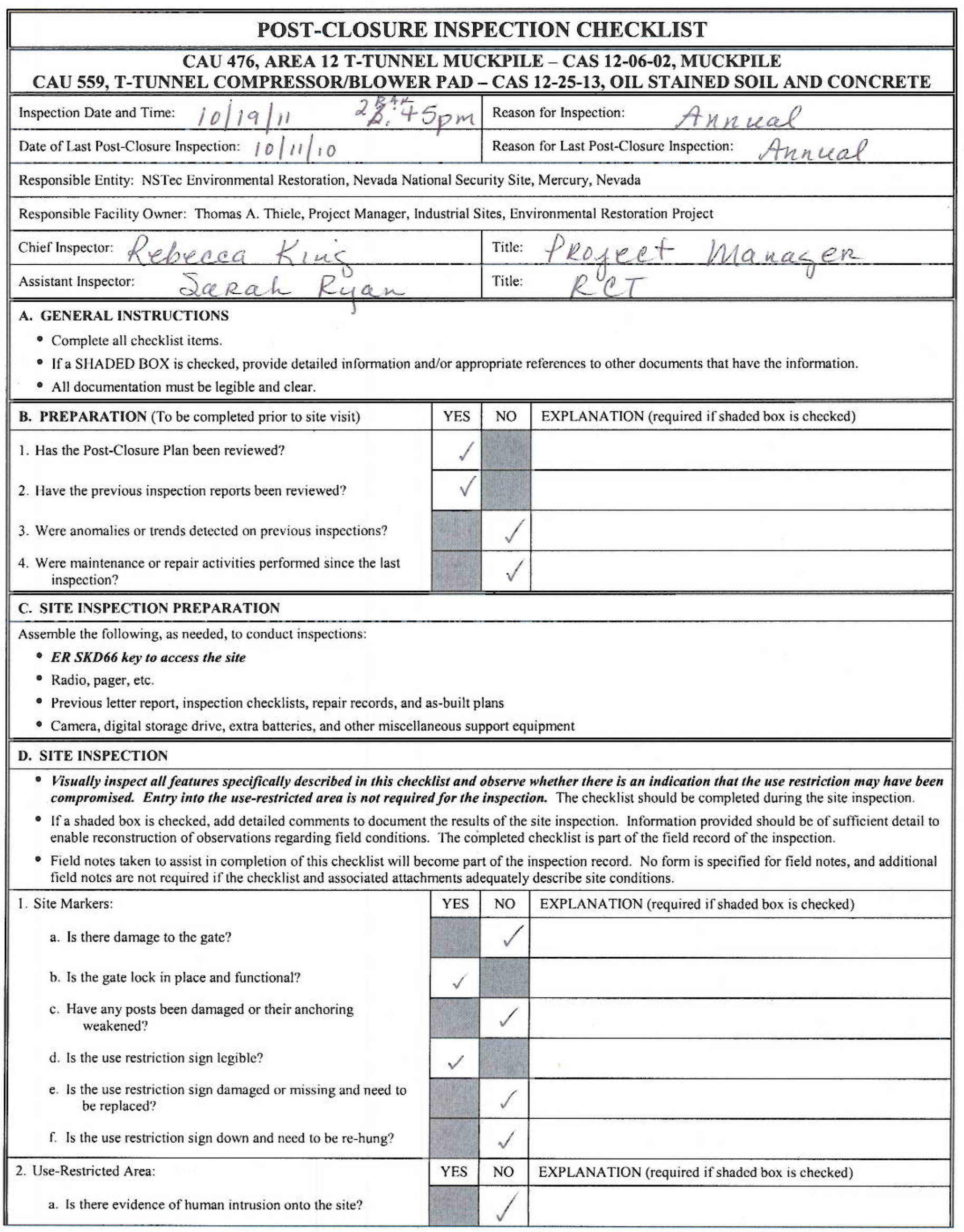




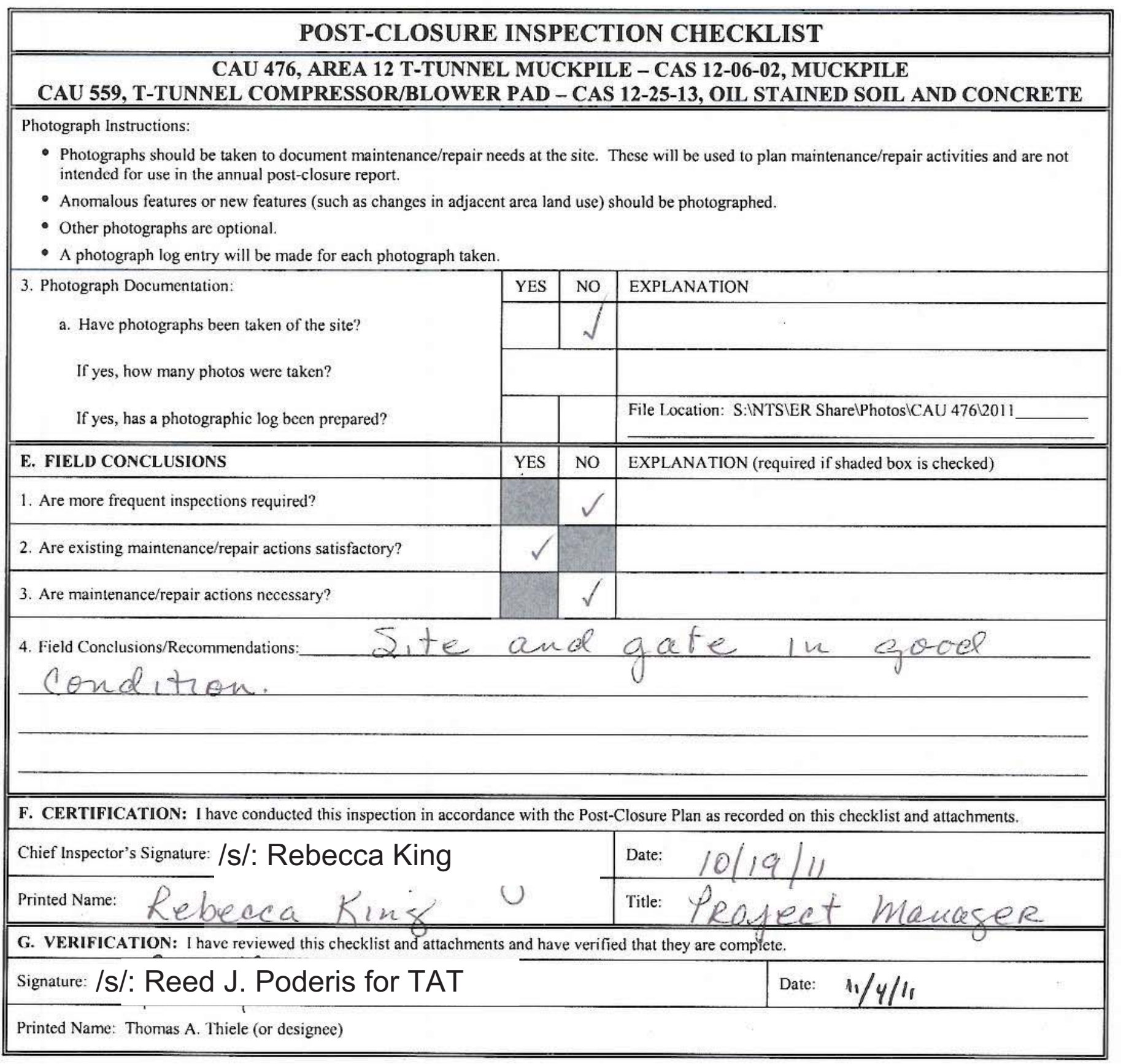


CAU 477: AREA 12 N-TUNNEL MUCKPILE 
THIS PAGE INTENTIONALLY LEFT BLANK 


\section{POST-CLOSURE INSPECTION CHECKLIST}

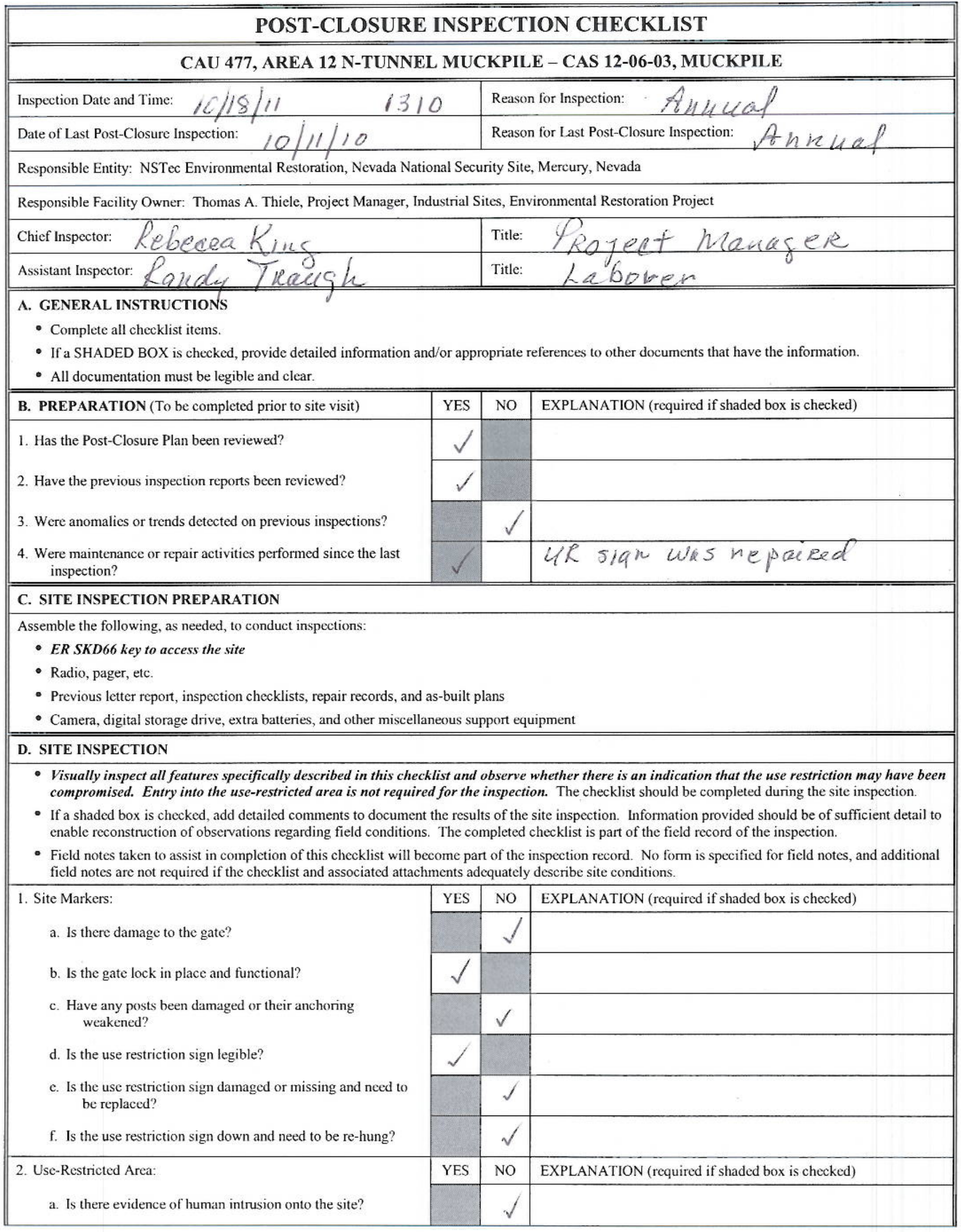




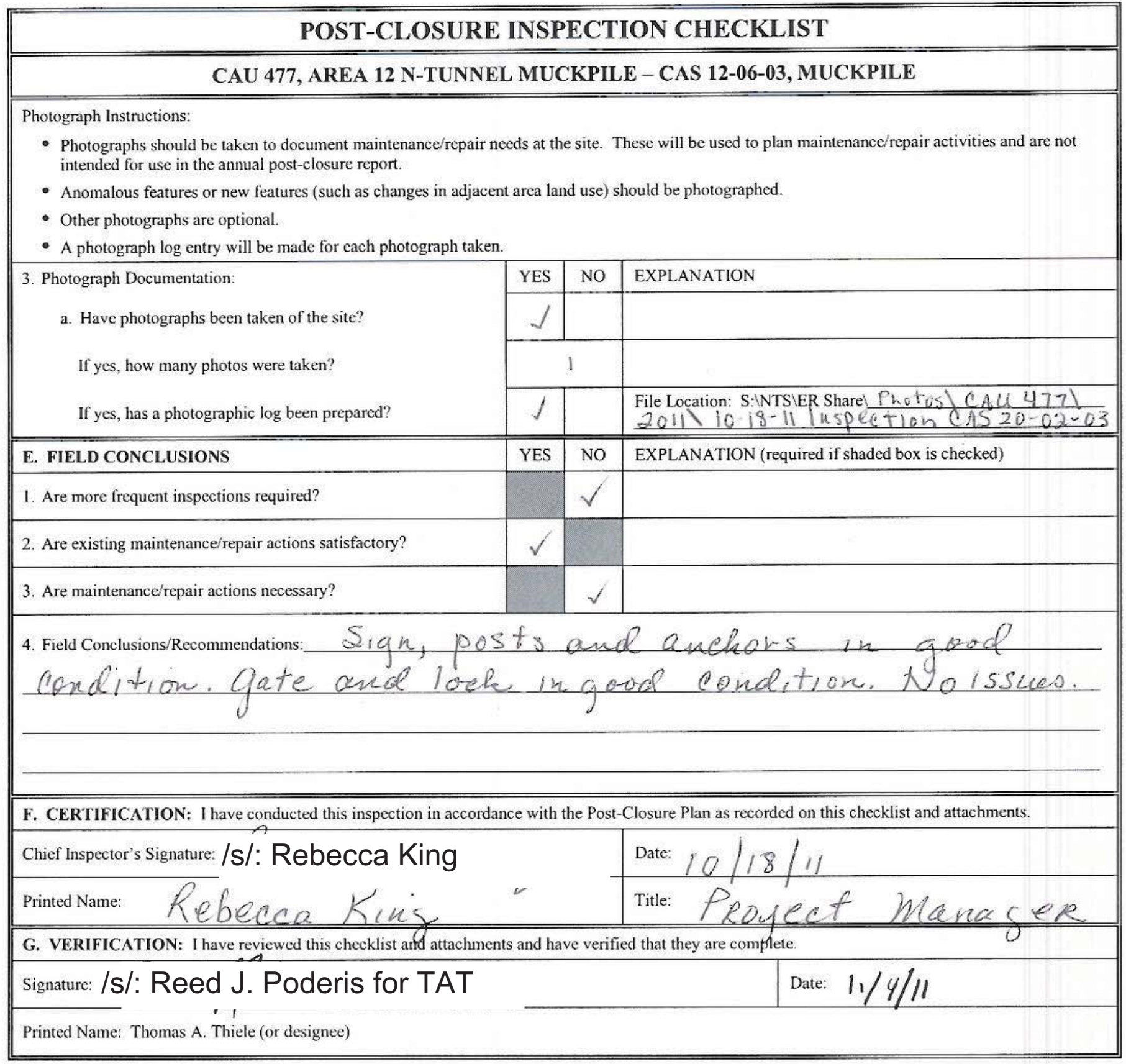


CAU 478: AREA 12 T-TUNNEL PONDS 
THIS PAGE INTENTIONALLY LEFT BLANK 


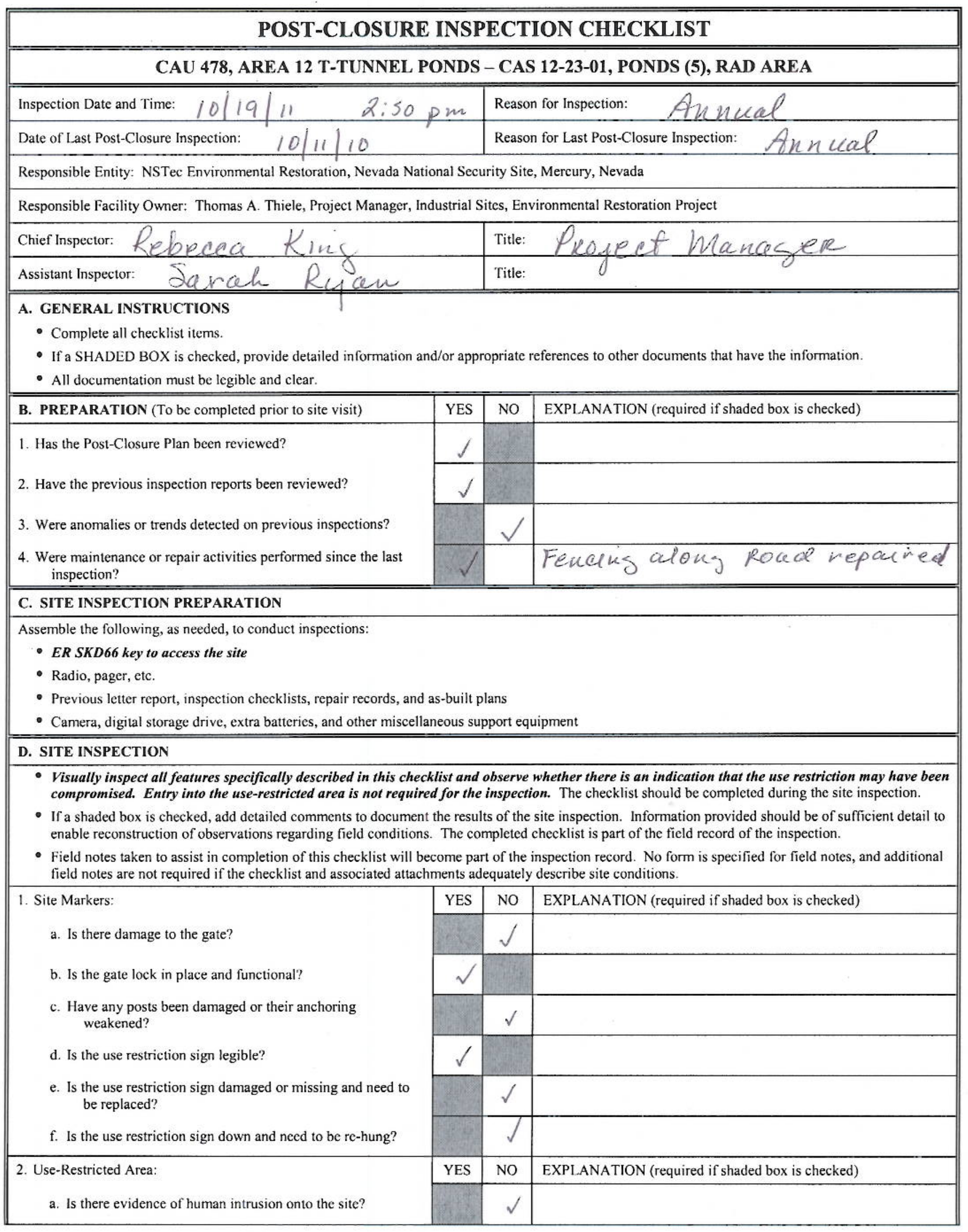




\section{POST-CLOSURE INSPECTION CHECKLIST}

\section{CAU 478, AREA 12 T-TUNNEL PONDS - CAS 12-23-01, PONDS (5), RAD AREA}

Photograph Instructions:

- Photographs should be taken to document maintenance/repair needs at the site. These will be used to plan maintenance/repair activities and are not intended for use in the annual post-closure report.

- Anomalous features or new features (such as changes in adjacent area land use) should be photographed.

- Other photographs are optional.

- A photograph log entry will be made for each photograph taken.

3. Photograph Documentation:

a. Have photographs been taken of the site?

If yes, how many photos were taken?

If yes, has a photographic $\log$ been prepared?

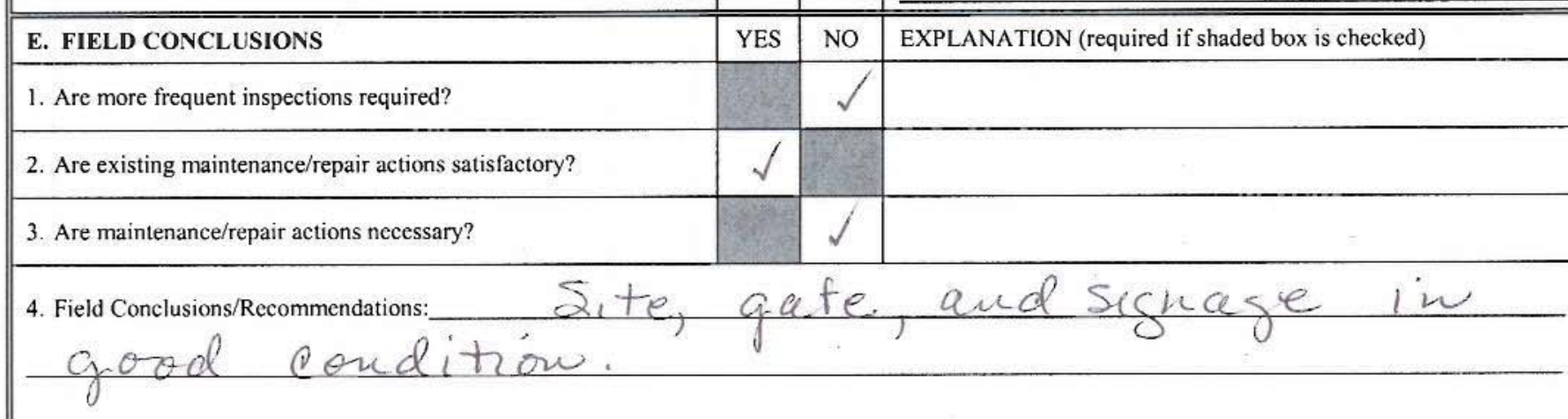

F. CERTIFICATION: I have conducted this inspection in accordance with the Post-Closure Plan as recorded on this checklist and attachments.

Chief Inspector's Signature: /s/: Rebecca King

Printed Name: Kebecea Krns

G. VERIFICATION: I have revieyed this checklist and attachments and have verified that they are complete.

\begin{tabular}{|c|r|l||}
\hline YES & NO & EXPLANATION \\
\hline & $\sqrt{ }$ & \\
\hline & & \\
\hline & & File Location: S: NTS $\backslash$ ER Share Photos $\backslash$ CAU 478\2011 \\
\hline YES & NO & EXPLANATION (required if shaded box is checked) \\
\hline & $\sqrt{ }$ & \\
\hline$\sqrt{ }$ & & \\
\hline
\end{tabular}

Date: $10 / 19 / 11$

0

Signature: /s/: Reed J. Poderis for TAT Date: $1 / 4 / 4$

Printed Name: Thomas A. Thiele (or designee) 
CAU 482: AREA 15 U15A/E MUCKPILES AND PONDS 
THIS PAGE INTENTIONALLY LEFT BLANK 


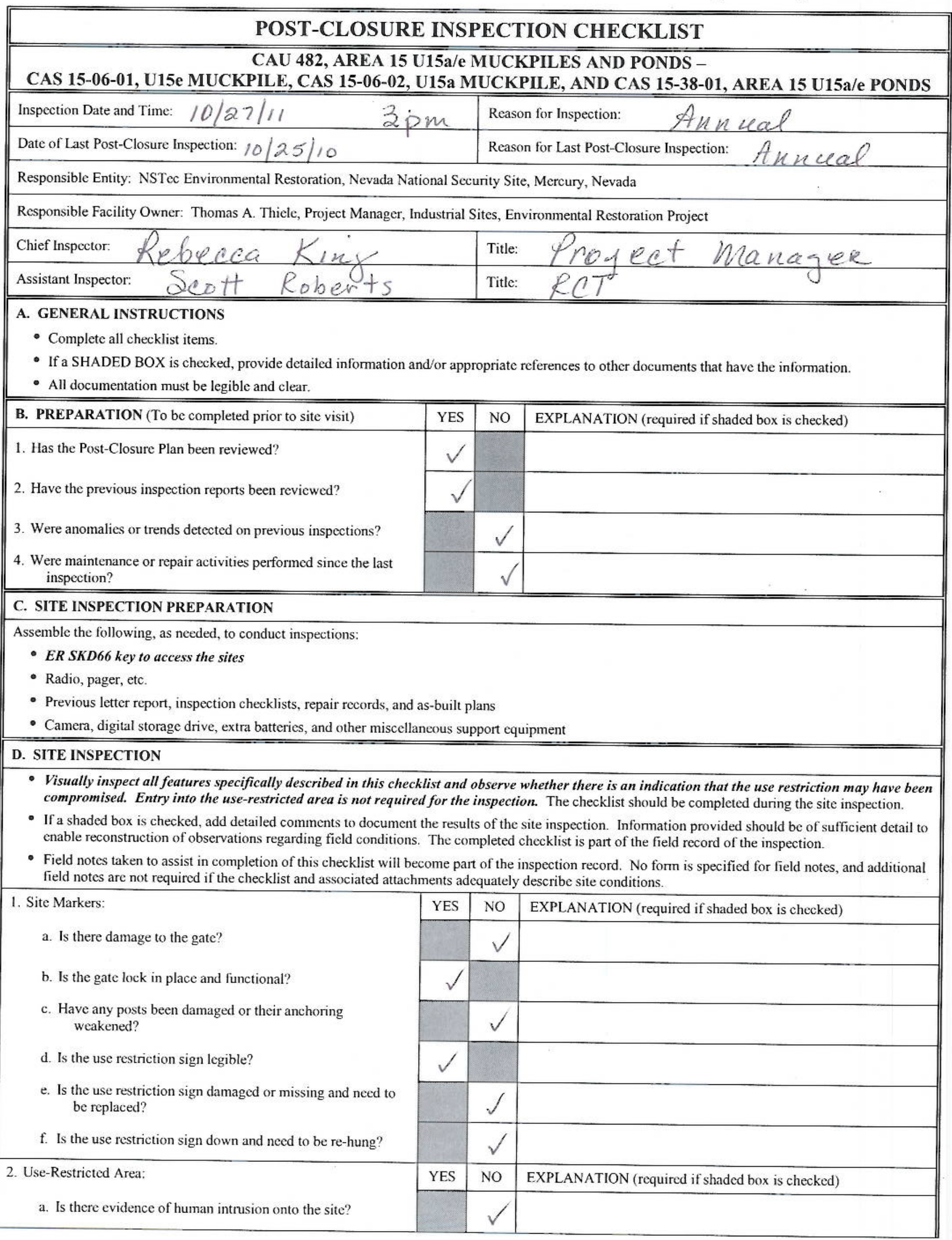


Inspection Requirement: Annual

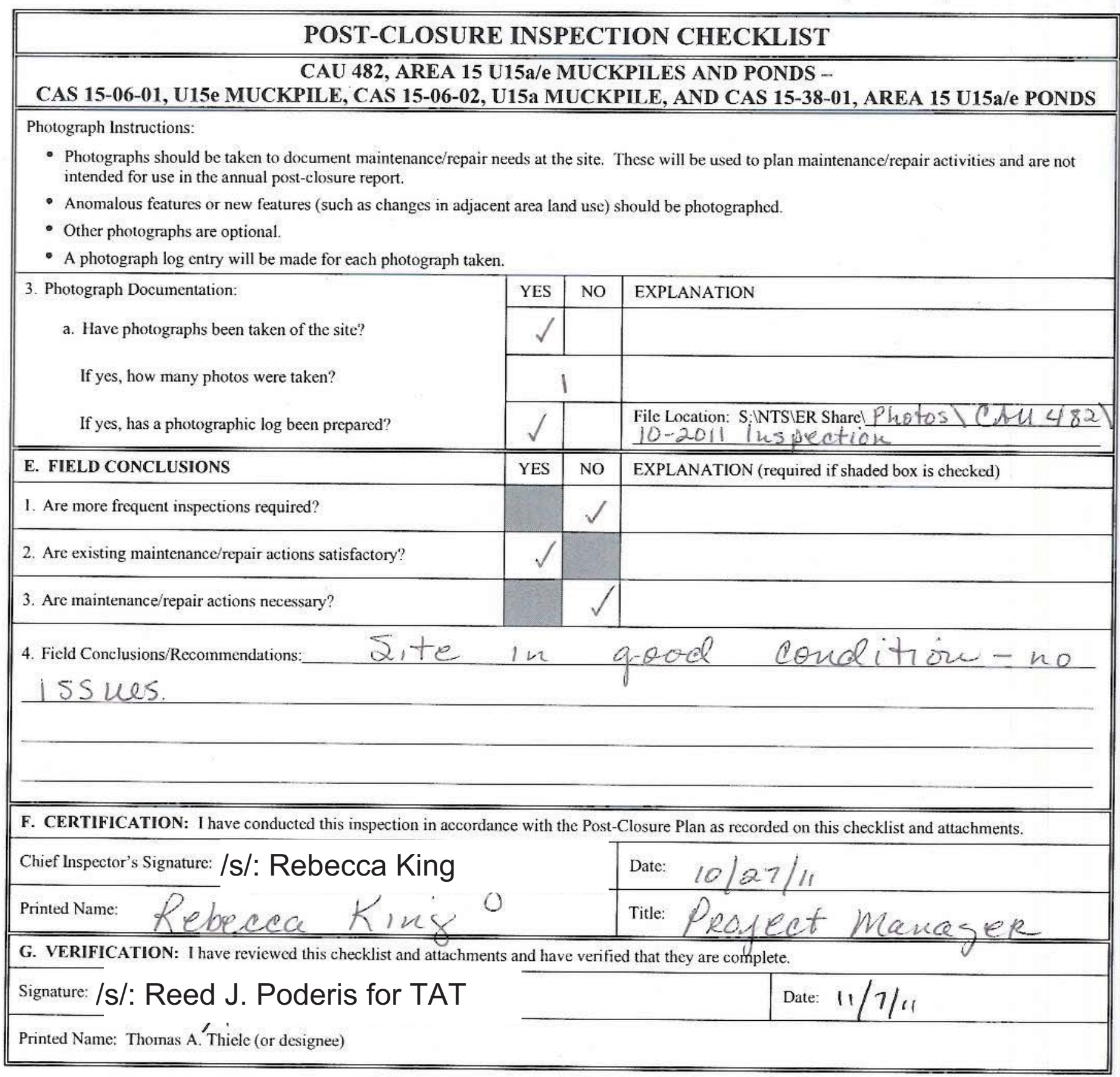

